\title{
In The Shadow of General Marshall: Old Soldiers in the Executive Branch
}

Ryan Edward Guiberson

Anaconda, Montana

Bachelor of Science, United States Air Force Academy, 1992

Master of Arts-Political Science, University of Florida, 1994

A Dissertation presented to the Graduate Faculty of the University of Virginia in Candidacy for the Degree of Doctor of Philosophy

Department of Politics

University of Virginia

August, 2013 


\begin{abstract}
The usurpation of political authority by tyrannical military figures is a theme that pervades the history of politics. The United States has avoided such an occurrence and the prospect of a military coup d'etat rarely registers as a realistic concern in American politics. Despite the unlikelihood of this classic form of military usurpation, other more insidious forms lurk and must be guarded against to protect civilian control of the military. One potential manifestation has been referred to as a military colonization of the executive branch. This form implies that retired senior military officers increasingly pursue executive branch positions and unduly promote the interests of the active duty military, its leaders, and military solutions to national security issues. This work addresses military colonization claims by examining the number of retired senior military officers that have served in executive branch positions, trends in where they participate, and their political behavior in these positions. It also uses interviews with retired senior military officers to gain their perspectives on the incentives and disincentives of executive branch service. The study concludes that in the post-Cold War period, participation rates of retired senior military officers in key executive branch positions do not diverge significantly from broader post-World War II patterns. In addition, their behavior while serving in these positions differs markedly from the expectations of military colonization purveyors. These individuals have predominantly reinforced civilian control of the military rather than impede it.
\end{abstract}

Ryan Guiberson is a Lieutenant Colonel in the United States Air Force and an assistant professor in the Department of Political Science at the United States Air Force Academy. This paper served as Lt Col Guiberson's Doctoral Dissertation, defended in June 2013 at the University of Virginia. The outstanding mentorship, advice, and tremendous intellectual support of James Ceaser, Sid Milkis, John, Owen, Andrew O'Shaughnessy, Nicole Pankiewicz, and Emily Sydnor provided critical support for this project. Where this paper contributes to political science scholarship, these individuals share in its value. The errors and shortcomings are the author's alone.

Disclaimer: The views expressed in this dissertation are those of the author and do not reflect the official policy or position of the United States Air Force, Department of Defense, or the U.S. Government. 


\section{Table of Contents}

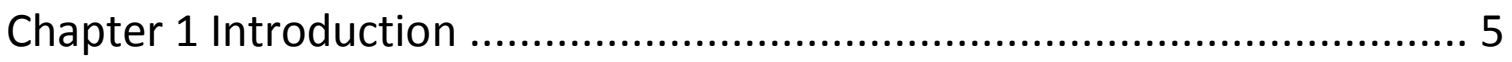

Chapter 2 Framing the RSO-Executive Branch Relationship ..................... 18 Chapter 3 RSOs \& the American Executive Branch: An Empirical Account . 61 Chapter 4 The Military Mind and RSO Executive Branch Participation ..... 145 Chapter 5 RSOs \& the Executive Branch: The RSO Perspective ............... 204

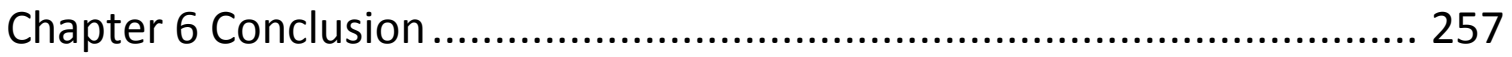




\section{List of Tables and Figures}

Table 2-1: Rank Distribution of the United States Active-Duty Military ...................................... 43

Figure 2-1: Categories of the RSO-Executive Branch Relationship ...............................................56

Table 3-1: Summary of Positions Subject to Noncompetitive Appointment................................ 71

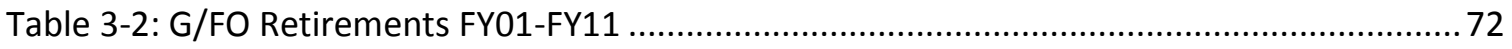

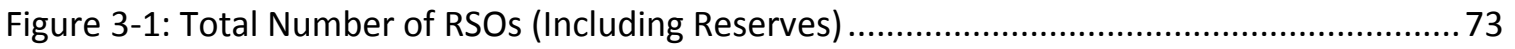

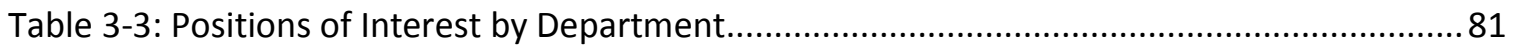

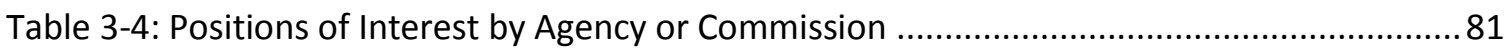

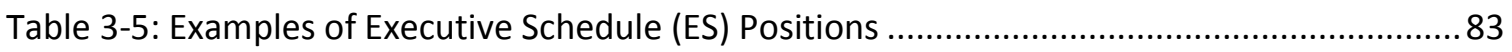

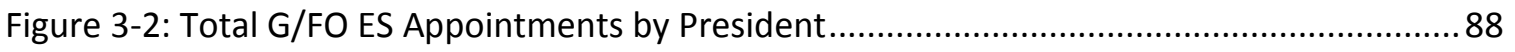

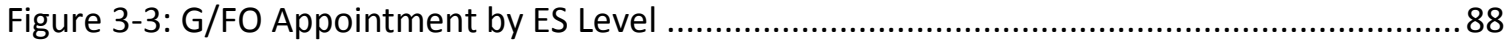

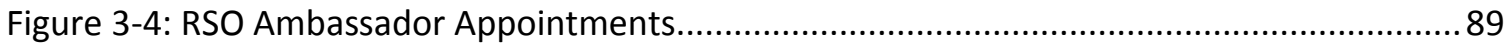

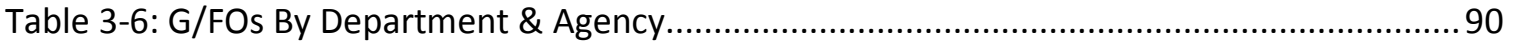

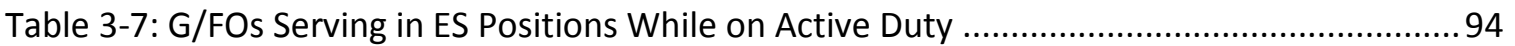

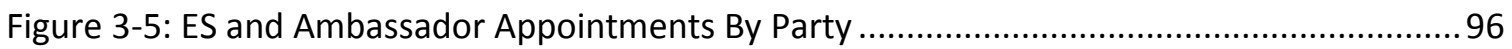

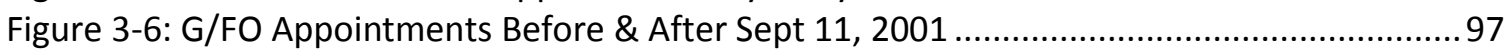

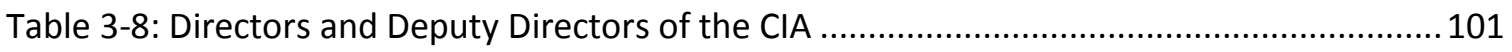

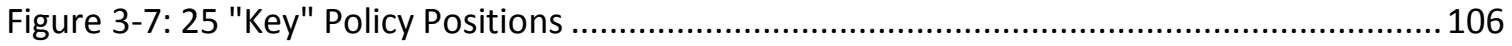

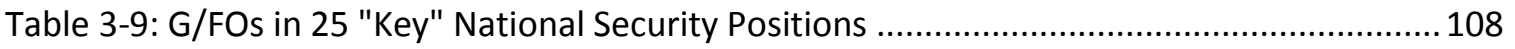

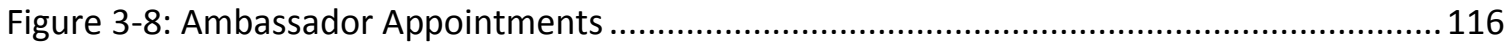

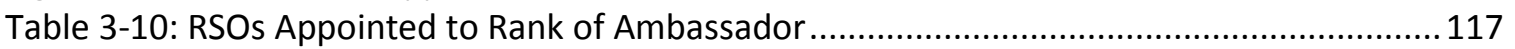

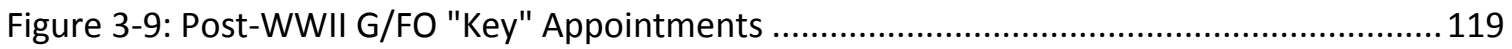

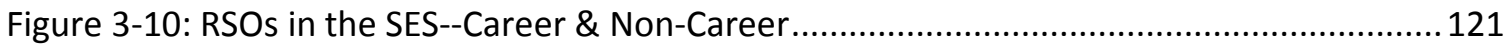

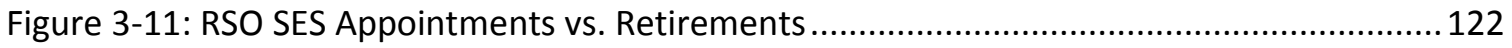

Figure 3-12: Career SES Appointments 2005-2012 Vets \& Colonels ......................................... 123

Figure 3-13: Non-Career SES Appointments 2005-2012 Vets \& Colonels ................................. 123

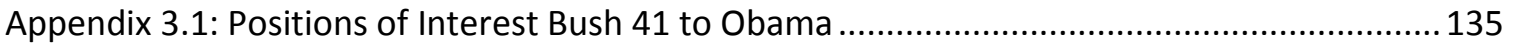

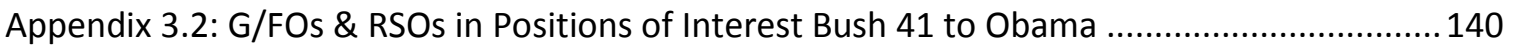

Appendix 3.3: G/FOs \& RSOs in Positions of Interest Truman to Reagan .................................. 143

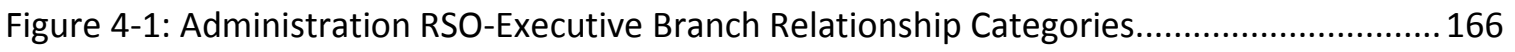

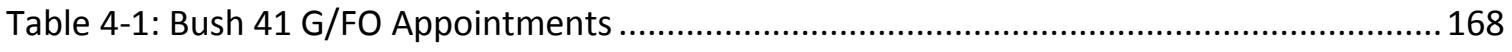

Table 4-2: Clinton G/FO Appointments (Active-Duty Highlighted) .......................................... 180

Table 4-3: Obama G/FO Appointees (Active Duty Highlighted) .............................................. 183

Table 4-4: Bush 43 G/FO Appointees (Active-Duty Highlighted) .............................................. 191 


\section{Chapter 1 Introduction}

\section{Retired Senior Military Officers and the Federal Executive Branch}

Politics is beyond the scope of military competence, and the participation of military officers in politics undermines their professionalism, curtailing their professional competence, dividing the profession against itself, and substituting extraneous values for professional values. ${ }^{1}$

The military profession exists to serve the state. To render the highest possible service the entire profession and the military force which it leads must be constituted as an effective instrument of state policy. Since political direction comes from the top, this means that the profession has to be organized into a hierarchy of obedience. For the profession to perform its function, each level within it must be able to command the instantaneous and loyal obedience of subordinate levels. Without these relationships, military professionalism is impossible. Consequently, loyalty and obedience are the highest military virtues. ${ }^{2}$

Samuel Huntington

The Soldier and the Statesman, 1957

It is not in the army that the remedy for the vices of the army can be encountered, but in the country.

\section{Alexis De Tocqueville \\ Democracy in America}

On Monday, March 30, 1981, a somewhat disheveled, tense, and short-of-breath

Alexander Haig entered the White House Press Room to address an anxious nation. In a performance that the media would broadcast continuously over the following days, the Secretary of State forcefully assured the country that despite the uncertain condition of President Reagan following an assassination attempt at the Washington Hilton, the

\footnotetext{
${ }^{1}$ Samuel P. Huntington, The Soldier and the State: The Theory and Politics of Civil-Military Relations (Cambridge, Mass: Belknap Press of Harvard University Press, 1957), 71.

${ }^{2}$ Ibid., 73.
} 
executive branch was not rudderless. Haig stepped into the leadership void ostensibly precipitated by the crisis, stating, "As of now, I am in control here, in the White House, pending return of the Vice President and in close touch with him." ${ }^{3}$ Haig's assertion garnered added scrutiny because it closely followed his erroneous interpretation of the current statutes on presidential succession; moments earlier Haig had explained to the press corps, "Constitutionally, gentlemen, you have the President, the Vice President, and the Secretary of State, in that order, and should the President decide he wants to transfer the helm, he will do so." ${ }^{4}$ Almost immediately after his comments, the media began to portray the effort as a brazen attempt to grasp at executive control during a potential national crisis.

Haig's physical appearance and mistaken description of the line of succession only added fuel to some existing perceptions of the Secretary. He had been routinely painted as an aggressive, take-charge, power-hungry, and self-aggrandizing public official. ${ }^{5}$ During Haig's confirmation hearings, Senator Paul Tsongas even presaged that the nominee was going to "...dominate this administration...[and would be]...the strongest personality that is going to be in there. ${ }^{\prime 6}$ Self-assured and ambitious public figures like Haig no doubt gravitate toward the upper reaches of executive politics in Washington. In Haig's case, however, these perceptions combined with another key feature of his public image to magnify the poignancy of his words: Haig was a former

\footnotetext{
${ }^{3}$ Alexander Haig, Jr., Caveat (New York: Macmillan Publishing Company, 1984), 160.

${ }^{4}$ Ibid.

${ }^{5}$ George J. Church, Dean Brelis, and Gregory H. Wierzynski, "The 'Vicar' Takes Charge," Time, March 16, 1981, 14.

${ }^{6}$ Senate Committee on Foreign Relations, Nomination of Alexander M. Haig, Jr., 97th Cong., $1^{\text {st }}$ sess., 1981, 337.
} 
army general. As a former military leader, whose army career spanned over thirty years, Haig had no doubt been inculcated with a philosophy that recognized no greater leadership sin than a failure to exert and convey command in a crisis. Recognizing a crisis in the confused moments following the assassination attempt, Haig showed no hesitancy in attempting to exert such command.

Haig's actions easily invite dramatizations about his underlying motives. Retrospections of journalists and scholars generally reflect a consensus, consistent with Haig's own subsequent claim, that the former general simply used exceedingly poor word choice during a tense period. ${ }^{7}$ Despite the media's relentless attention on Haig's rhetorical indiscretion, no remotely credible accounts suggested that the United States had witnessed an attempt to usurp executive power in the model of the South American coup d'etat. Sympathetic troops did not anxiously wait in the streets for direction from a new military master. It is admittedly even a stretch to mention the Haig incident in the context of military usurpation; the lack of a better example demonstrates just how far-removed the United States has been from such concerns. Media sensationalism aside, however, the incident should have reminded Americans, if only for a brief and perhaps fleeting moment, that despite our country's long history of civilian and constitutional government, the "man on horseback" claims a much longer and prevalent past. $^{8}$

\footnotetext{
${ }^{7}$ Haig, Jr., Caveat, 164.

${ }^{8}$ S. E. Finer, The Man on Horseback; the Role of the Military in Politics (New York: Praeger, 1962).
} 
The "man on horseback" version of coup d'etat represents the most extreme political manifestation of military usurpation, but other troublesome forms lurk as well. For example, a nation maintaining a large military force, albeit loyal to civilian masters, can precipitate its own demise by allowing an army to drain its financial, material, and personnel resources. ${ }^{9}$ Furthermore, a powerful and influential military can entangle the nation in unwanted and ill-advised conflicts or unnecessarily excite public anxiety over imagined or inconsequential security threats. Therefore, figures like Haig can represent not only the highly unlikely specter of military dictatorship in the United States, but also, they signify the possibility that military leaders may use their national security expertise and public prestige to promote a more insidious militarization of democratic institutions. As scholar Samuel Huntington noted, "the problem in the modern state is not armed revolt but the relation of the expert to the politician." ${ }^{10}$

The Haig incident admittedly represents a sensationalized entry point into the study of civil-military relations in the United States. Haig served as a civilian, in a civilian executive branch position, and at the behest of a democratically elected civilian president. However, this historical episode provides a fruitful launching point for examining the cautious ambivalence that surrounds the modern relationship between former senior military officers and American executive branch politics. This uncertainty invites important questions for political science. For example, should retired senior military officers be understood as "civilian" citizens, or do they maintain a distinctly

\footnotetext{
${ }^{9}$ Peter D. Feaver, "The Civil-Military Problematique: Huntington, Janowitz, and the Question of Civilian Control," Armed Forces \& Society (Winter 1996): 154.

${ }^{10}$ Huntington, The Soldier and the State, 20.
} 
different middling status between civilian democratic society and a coexisting military society? Do military leaders, active and former, possess a distinct military ideology or "military mind"? ${ }^{11}$ If so, does this military mind become so deeply embedded in military leaders that, even after their retirement, democratic politics must keep them at a safe distance? Also, does the presence of a significant number of retired senior officers in high executive branch positions portend a "militarization" of democratic government? ${ }^{12}$ In short, what role do retired senior military officers play in American politics and what role should they play?

This dissertation addresses some of these fundamental questions by focusing on the relationship between retired senior military officers and the federal executive branch in the United States. Before outlining the thesis and overall plan of this study two central terms used throughout the work require some elaboration. First, retired senior military officer, or "RSO," refers to retired American military officers who once held the rank of General or Admiral in the United States' Armed Forces. This label applies to all ranks of retired generals and admirals, reserve or regulars, from one-star to the pinnacle four-star leaders. The second widely-referenced term, "G/FO," short for General/Flag Officer, encompasses not only RSOs but also those generals and admirals currently in active service. This study considers the relationship of both of these two groups to the federal executive branch, but RSOs are its central focus.

\footnotetext{
11 Ibid., chap. 3.

${ }^{12}$ Bruce Ackerman, The Decline and Fall of the American Republic (Cambridge, Mass: Belknap Press of Harvard University Press, 2010), chap. 2.
} 
The work examines how the participation of RSOs in the executive branch relates to understandings of healthy civil-military relations, and more generally, how this interaction meshes with other central themes in American politics. The way in which Americans perceive the role of RSOs in the U.S. political system, especially in the executive branch, arguably reveals a great deal about their conceptions of democratic institutions, civic republicanism, and the appropriate orientation of the military and its leaders toward politics. ${ }^{13}$

Recent scholarly work on civil-military relations provides important theoretical and empirical insight into the activities of RSOs outside formal government institutions. For instance, scholars study candidate endorsements by retired military officers, RSO participation at party conventions, and cases where RSOs engage in public critiques of government policies. ${ }^{14}$ However, these recent works neglect the relationship between RSOs and their formal participation in the federal executive branch. Existing frameworks fail to adequately address whether executive branch RSOs generally promote or frustrate healthy civil-military relations and other ways this form of political

\footnotetext{
${ }^{13}$ James Burk, "Theories of Democratic Civil-Military Relations," Armed Forces \& Society 29, no. 1 (October 2002): 7-29.

${ }^{14}$ James Golby, Kyle Dropp, and Peter Feaver, Military Campaigns: Veterans' Endorsements and Presidential Elections (Center for a New American Security, October 2012), http://www.cnas.org/files/documents/publications/CNAS_MilitaryCampaigns_GolbyDroppFeaver.pdf; Risa A. Brooks, "Militaries and Political Activity in Democracies," in American Civil-Military Relations: The Soldier and the State in a New Era, ed. Suzanne C. Nielsen and Don M. Snider (Baltimore: The Johns Hopkins University Press, 2009), 213-238; Richard H. Kohn, "Building Trust: Civil-Military Behaviors for Effective National Security," in American Civil-Military Relations: The Soldier and the State in a New Era, ed. Suzanne C. Nielsen and Don M. Snider (Baltimore: The Johns Hopkins University Press, 2009), 264289; Richard H. Kohn, "Military Endorsements Harm National Interest," The Washington Times, October 15, 2000, sec. Letters to the Editor, http://www.washingtontimes.com/news/2000/oct/15/20001015012137-3090r/?page=all; Army Times, "Mitt Romney's 'Military Advisory Council' - Army News | News from Afghanistan \& Iraq - Army Times," accessed November 19, 2012, http://www.armytimes.com/news/2012/10/military-romney-endorsement-list-101812w.
} 
participation influences American government. The absence of accessible empirical data on the number of RSOs that serve in executive administrations in large part explains the scarcity of scholarly analysis.

Yale professor Bruce Ackerman represents a notable exception to the current dearth of scholarly work on the subject. In The Decline and Fall of the American Republic (2010), Ackerman contends that retired military officers play an increasingly prominent role in the executive branch both in number and influence. He pejoratively labels this perceived trend the "military colonization" of the executive branch. ${ }^{15}$ While similar accusations are not unique to the post-Cold War period, he argues that the trend has accelerated over the last few decades and laments that its potential consequences evoke little consternation among elected officials or the American public. ${ }^{16}$ Ackerman warns, "[t]he principle of civilian control is losing its basis in sociological reality: senior officers are talking to (retired) senior officers about high matters of policy on a regular basis." ${ }^{17}$ Citing the number of former military men in positions such as the service secretaries (i.e., Secretary of the Air Force, Navy, etc.), the National Security Advisor, the Director of National Intelligence, and the Director of the CIA, Ackerman claims the colonization process signals a drift from previous eras of robust civilian control of the military. He goes on to argue that the distinction between military and civilian governmental functions and capabilities has become blurred, especially in post-9/11 law enforcement and intelligence activities. Civilian departments and agencies increasingly

\footnotetext{
${ }^{15}$ Ackerman, The Decline and Fall of the American Republic, 57.

${ }^{16}$ Ibid., chap. 2.

${ }^{17}$ Ibid., 59.
} 
possess capabilities that were viewed as decidedly military only a decade ago. News broadcasts during the recent search for the Boston Marathon bombing suspects arguably lend credence to this part of his claim. In this episode, law enforcement's armored vehicles, aerial surveillance, high-powered weaponry, and full combat dress made their visible distinction from military forces nearly unintelligible. Moreover, Ackerman argues, changes to the organizational structure of the military leadership have encouraged the "politicization" of top active officers and the rise of "celebrity" generals. He warns that these trends portend far-reaching implications for civil-military relations, national security policy, and democratic government in general.

Such depictions give strong reason for concern and pose significant issues for civil-military relations and American politics. But, do these claims match reality? Ackerman focuses on a small sample of the highest, most visible senior policy positions in the executive branch, but he does not give a full accounting of the breadth and depth of military colonization. An adequate examination of the colonization issue requires a more expansive analysis and one that reveals the full extent of RSO participation. This analysis must not only focus on the senior levels but also the lower operational tiers of the executive branch where potential fusions between law enforcement, military functions, and diplomacy would ostensibly present the most insidious dangers. For example, agencies such as the FBI, DEA, ATF, FAA, Customs and Border Protection, TSA etc., represent organizations where evidence of colonization could substantiate Ackerman's concerns. These agencies directly influence issues related to national security, and colonization by military personnel, if extant, warrants scrutiny. 
In addition to concerns over the number of RSOs, colonization claims also imply an ideological homogeneity among military officers, or worse, an unreflective loyalty to the institutional military, its culture, its preferences, and the military's rigid hierarchical structure. These arguments also require further scrutiny because they characteristically fail to consider that distinctions may exist between the policy preferences and/or ideological dispositions of active military leaders and retired senior military leaders serving in executive branch positions. More importantly, colonization claims seemingly discount the practical significance of a fundamental and deeply embedded premise in the American military tradition: an officer's sworn oath to the Constitution and the nation's democratically elected leaders. Moreover, military colonization purveyors concentrate predominantly on the harmful implications of RSOs serving in the executive branch, and, as a consequence, the potential positive role these figures may play gets overlooked. This work aims to consider this neglected feature of military colonization claims.

The core argument of this study asserts that executive branch RSOs have served a positive and valuable function for American politics and their actions have neither been consistent with those implied in colonization claims nor have they generated the harmful effects envisaged by military colonization purveyors. To develop this argument, this study offers a descriptive framework for categorizing RSO-executive branch relationships based on an empirical look at the number and behavior of RSOs who have served in the executive branch. This assessment expands the existing research on RSOs beyond the most senior officials and looks deeper into the lower tiers of presidential 
appointments in the post-Cold War presidential administrations. It unearths the number of RSOs who have held executive branch positions, where they have served, and the study examines common characteristics among them. Qualitative aspects of the study consider possible reasons why RSOs serve in high-level executive branch positions and what incentives or disincentives likely promote or impede their participation. Understandings of potential motivations and how RSOs view executive branch opportunities help frame the potential consequences of their participation. The qualitative research builds on other studies in political science that consider the differences in political ideologies and world views between civilian elites, military elites, and the broader American populace. The research also examines potential legal and structural barriers that may inhibit RSO participation and considers the genesis of those barriers. The descriptive framework presented in the study combines the quantitative and qualitative research to describe categories in the RSO-executive branch relationship and the alternative consequences represented by each of them.

The chapters introduced below address different aspects of the RSO-executive branch relationship. Taken together, they contribute to a better understanding of RSOs in the post-Cold War period. The study's central argument is that these former senior officers countervail rather than exacerbate dangers implied by military colonization claims, provide a source of unique leadership and technical expertise, and perhaps even help restrain partisan excesses. RSOs, it will be argued, have mitigated the civil-military tensions inherent in liberal-democratic political systems. The structure of American politics ensures the dangers implied by military colonization will continually exist as 
latent threats; however, the post-Cold War period demonstrates that the soldierstatesman image best exemplified by General George Marshall predominantly guides the RSOs who have served in the executive branch and their actions have stood in stark contrast to military colonization characterizations.

\section{Substantive Chapter Summaries}

Chapter 2 outlines the unique characteristics of the political actors at the center of the entire study: RSOs. The chapter lays out the theoretical groundwork that explains why RSOs deserve special consideration in American politics and outlines a group of interacting traits possessed by these former officers that make their relationship to the federal executive branch noteworthy. The chapter concludes with a categorization framework for considering military colonization claims and offers alternative ways to understand the RSO-executive branch relationship. The descriptive framework incorporates the purported defining features associated with military colonization: a growing number of RSOs in the executive branch, their ideological homogeneity, and tensions in civil-military relations. The framework provides a structure for interpreting the empirical data presented in the subsequent chapters.

Chapter 3 unearths the number of RSOs across the highest civilian policy making positions in the federal executive branch. The analysis focuses primarily on the postCold War administrations of George H.W. Bush through President Barak Obama, and examines characteristics of RSO participation across and within these administrations. 
The chapter also contains a broader glimpse at the entire Cold War period, comparing earlier presidencies with trends in post-Cold War administrations.

Building on the empirical data from the previous section, Chapter 4 uses qualitative data to categorize post-Cold War administrations according to the framework outlined in Chapter 2. The discussion compares existing survey research on the political and ideological orientations of military officers with historical evidence on particular RSOs that served in the executive branch. The chapter concludes with a brief discussion on the legal impediments related to the RSO-executive branch relationship.

Chapter 5 uses responses from personal interviews with RSOs to assess how they perceive their relationship to the executive branch and the implications for civil-military relations. The RSOs interviewed include some that served in President AppointedSenate confirmed positions (PAS) or Senior Executive Service (SES) positions, while others had either declined positions or were never offered executive branch opportunities. These interviews uncover the RSOs' potential incentives and disincentives in accepting executive branch positions, as well as the organizational and cultural hurdles that may impede their participation. Their responses challenge the idea that presidentially appointed RSOs act simply as proxies for the active military and suggest that RSO participation in the executive branch does not necessarily present the acute dangers to democratic government implied in military colonization claims.

The concluding chapter considers the normative implications of the findings from the earlier chapters on civilian-military relations. The closing remarks assess 
military colonization claims in light of the findings and discuss potential implications.

Finally, some avenues for future research on RSOs and their relationship to the American political system are offered for consideration. The civil-military relations theories that anchor this study provide alternative interpretations of democratic governance and how best to protect and sustain it. This work adds to these theories by highlighting a neglected aspect of civil-military relations scholarship: the RSO-executive branch relationship. 


\title{
Chapter 2 Framing the RSO-Executive Branch Relationship
}

\begin{abstract}
It is my conviction that the necessary and wise subordination of the military to civil power will best be sustained... when lifelong professional soldiers, in the absence of some obvious and overriding reasons, abstain from seeking high political office.
\end{abstract}

Dwight D. Eisenhower to Manchester Union Leader editor Leonard B. Finder, January 22, $1948^{18}$

Some of the best advice I was given is that when a general officer retired, he should never pass up an opportunity to remain silent. ${ }^{19}$

General Norman Schwarzkopf

The central task of this chapter is to construct a descriptive framework for categorizing the RSO-executive branch relationship. The structure must take into account the concerns related to military colonization, but also highlight alternative ways of interpreting the RSO-executive branch relationship. Incorporating some unique characteristics shared by RSOs, the proposed framework describes the beneficial features that RSOs may bring to executive branch service. However, before unveiling the descriptive categories in the framework, the discussion must deal with two

\footnotetext{
${ }^{18}$ Jean Edward Smith, Eisenhower in War and Peace (New York: Random House, 2012), 471.

${ }^{19}$ As quoted in Kohn, "Building Trust: Civil-Military Behaviors For Effective National Security," 284.
} 
underlying questions: 1) Do RSOs as a subgroup really warrant special attention in American politics, and 2) what "hole" could a descriptive categorization of the RSOexecutive branch relationship attempt to fill in the broader academic field of civilmilitary relations theory ${ }^{20}$ Answers to these questions will help situate the military colonization question and lay the foundation for judging its contemporary relevance.

To begin this discussion, the latter question gets treated first: where do RSOs fit in civilmilitary relations theory?

\section{Civil Military Relations and The Problematique}

Scholar Peter Feaver aptly labeled the central paradox of civil-military relations theory, simply, the "problematique." ${ }^{21}$ In short, the problematique tasks the sovereign power, whether an autocrat, a group of oligarchic leaders, or the people, to balance two conflicting imperatives: the need for a military force to provide security against external threats to the state, and the corresponding need to ensure that this same force does not in turn destroy the political order and/or the political values it was created to protect. $^{22}$ The problematique is the parallel of the "security dilemma" in international

\footnotetext{
${ }^{20}$ see Douglas L. Bland, "A Unified Theory Of Civil-Military Relations.," Armed Forces \& Society (Fall 1999): 7-12. Bland identifies four main but highly interrelated concerns addressed in civil-military relations theory: 1) the "Praetorian Problem" which focuses on curbing the political power of the military, 2) the problem of ensuring the civilian leadership doesn't use the military for partisan purposes, 3) the problem presented by the ostensible disparity between military and civilian expertise on matters of war, and 4) the Problematique which provides the theoretical entry point for this study.

${ }^{21}$ Feaver, "The Civil-Military Problematique."

${ }^{22}$ Mackubin Thomas Owens, US Civil-Military Relations After 9/11 : Renegotiating the Civil-Military Bargain (New York: Continuum, 2011), 12.
} 
relations theory played out within the confines of national boundaries. ${ }^{23}$ Feaver explains:

Indeed, an inadequate military institution may be worse than none at all. It could be a paper tiger inviting outside aggression; strong enough in appearance to threaten powerful enemies, but not strong enough in fact to defend against their predations. Alternatively, it could lull leaders into a false confidence, lead them to rash behavior, and then fail in the ultimate military contest. ${ }^{24}$

The problematique aligns with Madison's position in Federalist 51 regarding democratic institutional theory: "In framing a government which is to be administered by men over men, the great difficulty lies in this: you must first enable the government to control the governed; and in the next place oblige it to control itself." 25 Federalist 51 responds by recommending "auxiliary precautions" to help balance these competing requirements. Like Madison, civil-military relations theorists often look to alternative institutional designs to address the problematique and to provide the auxiliary precautions that contribute to the normative success or failure of the relationship between civil institutions, society, and its military forces. The Constitution provides many of these precautionary devices, but these "parchment barriers" alone cannot sufficiently manage the problematique. Cultural norms within civil society and the military also reinforce these structural mechanisms.

The civil-military relations subfield therefore examines both institutional design as well as the cultural or sociological dynamics inherent in the problematique. These two approaches, or what civil-military scholar Mackubin Thomas Owens calls lenses,

\footnotetext{
${ }^{23}$ Robert Jervis, Perception and Misperception in International Politics (Princeton, N.J.: Princeton University Press, 1976), 62-113.

${ }^{24}$ Feaver, "The Civil-Military Problematique," 152.

${ }^{25}$ Alexander Hamilton, John Jay, and James Madison, The Federalist, ed. George W. Carey and James McClellan, 2nd ed. (Indianapolis, IN: Liberty Fund, 2001), 269.
} 
have profoundly shaped the contours of the subfield and are anchored in two influential masterpieces. Samuel Huntington's The Soldier and the State (1957) framed the institutional or normal theory in civil-military relations, and Morris Janowitz's The Professional Soldier (1960) anchored the military sociological or cultural approach. ${ }^{26}$ Despite different focuses, the approaches share some common premises, two which hold central importance in this study: 1) protecting liberal-democracy requires that the principle of civilian control of the military prevails, and 2) military professionalism resides at the heart of successful civil-military relations and must be continuously cultivated.

To achieve the desired ends implied in these premises, each theory prescribes different means for successfully managing the interaction of the military, democratic politics, and civic republican ideals. ${ }^{27}$ The RSO resides in an ill-defined space created in this interaction and their vague status complicates understandings of the limits of military professionalism. Therefore, deciphering the RSO's place in American politics, and specifically the executive branch, requires a grasp of the theoretical prescriptions offered by these two prominent approaches and their particular conceptions of military professionalism. Ultimately, neither prescription nor concept adequately accounts for the retired senior military officer.

\footnotetext{
${ }^{26}$ Owens, US Civil-military Relations After 9/11; Samuel P. Huntington, The Soldier and the State: The Theory and Politics of Civil-Military Relations (Cambridge, Mass: Belknap Press of Harvard University Press, 1957); Morris Janowitz, The Professional Soldier, a Social and Political Portrait. (Glencoe, IL: Free Press, 1960); While Janowitz's is overwhelmingly cited, other earlier and later works also deserve "founding" recognition. See Samuel A. Stouffer et al., The American Soldier: Adjustment During Army Life, 1st ed. (Princeton University Press, 1949).

${ }^{27}$ See Burk, "Theories of Democratic Civil-Military Relations."
} 


\section{The Normal Theory of Civil-Military Relations}

Samuel Huntington ignited the post-World War II scholarly debate about civilmilitary relations. His model remains influential today predominantly because the institutional military has fully embraced its underlying tenets. ${ }^{28}$ The Soldier and the State reoriented the academic focus of the sub-field away from the dominant research trends of the time and toward macro-level theorizing. ${ }^{29}$ Early "behavioral" post-war studies reflected prevailing social science methodologies, focusing on survey data collection and analysis, but these studies eschewed grander theoretical ambitions. ${ }^{30}$ Huntington's work made the theoretical leap in part by switching the unit of analysis from the enlisted citizen-soldier, prevalent in behavior studies, to a singular military officer corps. ${ }^{31}$ His approach diverged from the broader social science trends that atomized the political world into individual actors and deemphasized the role of institutions and groups. ${ }^{32}$

\footnotetext{
${ }^{28}$ Peter D. Feaver, Armed Servants: Agency, Oversight, and Civil-Military Relations (Cambridge, Mass: Harvard University Press, 2005), 7; Eliot A. Cohen, "The Unequal Dialogue: The Theory and Reality of CivilMilitary Relations and the Use of Force," in Soldiers and Civilians: The Civil-Military Gap and American National Security (Cambridge, Mass: MIT Press, 2001), 435; Feaver, "The Civil-Military Problematique," 158.

${ }^{29}$ Peter D. Feaver and Erika Seeler, "Before and After Huntington: The Methodological Maturing of CivilMilitary Studies," in American Civil-Military Relations: The Soldier and the State in a New Era, ed. Suzanne C. Nielsen and Don M. Snider (Baltimore: The Johns Hopkins University Press, 2009), 72-90.

${ }^{30}$ Donald R. Kinder, "Pale Democracy: Opinion and Action in Postwar America," in The Evolution of Political Knowledge: Theory and Inquiry in American Politics, ed. Edward D. Mansfield and Richard Sisson (Columbus OH: Ohio State University Press, 2004), 104-147; Feaver and Seeler, "Before and After Huntington: The Methodological Maturing of Civil-Military Studies."

${ }^{31}$ For example, Stouffer et al., The American Soldier.

${ }^{32}$ Alan S. Zuckerman, "Returning to the Social Logic of Political Behavior," in The Social Logic Of Politics: Personal Networks As Contexts For Political Behavior, ed. Alan S. Zuckerman (Philadelphia: Temple University Press, 2005), 3-20; Theda Skocpol, "Bringing the State Back In: Strategies of Analysis in Current Research," in Bringing the State Back In, ed. Peter B. Evans, Dietrich Rueschemeyer, and Theda Skocpol (Cambridge, Mass: Cambridge University Press, 1985), 3-43.
} 
According to Huntington, patterns of civilian control of the military reflected the competition between two political necessities or "imperatives": the functional imperative and the societal imperative. The functional imperative represented the physical security requirements of the state, whereas the societal element reflected America's commitment to particular political values. ${ }^{33}$ Huntington's societal imperative contained two sub-factors: the nation's dominant "liberal" political ideology, and the structural constant represented by the Constitution. The contending imperatives, the functional and the societal, continually interact in a near zero-sum relationship. Across time this interaction has revealed itself through different modes of civilian control of the military.

External threats posed only sporadic and relatively muted concerns throughout most of American history, and therefore Huntington's societal imperative consistently trumped the functional one in political relevance. ${ }^{34}$ Geography provided near impervious barriers against military invasion and American liberalism developed unencumbered by acute security concerns. ${ }^{35}$ At certain times, for example the Civil War and World War I, the functional imperative commanded more attention, but its priority status evaporated quickly after each conflict. The United States adhered to a pattern of

\footnotetext{
${ }^{33}$ Huntington, The Soldier and the State, 2.

${ }^{34}$ For alternative viewpoint on $19^{\text {th }}$ century security concerns, Richard H. Kohn, "Building Trust: CivilMilitary Behaviors For Effective National Security," in American Civil-Military Relations: The Soldier and the State in a New Era, ed. Suzanne C. Nielsen and Don M. Snider (Baltimore: The Johns Hopkins University Press, 2009), 266. Cites C. Van Woodwards 1960 essay in the American Historical Review, revised in 1989 as the "Age of Reinterpretation" in C. Van Woodward, The Future of the Past (New York: Oxford University Press, 1989), pp. 75-94.

${ }^{35}$ Louis Hartz, The Liberal Tradition in America; an Interpretation of American Political Thought Since the Revolution. (New York: Harcourt, Brace, 1955); Alexis de Tocqueville, Democracy in America, trans. Harvey C. Mansfield and Delba Winthrop (Chicago: University of Chicago Press, 2011).
} 
military unpreparedness and rapid mobilization at the beginning of conflicts, followed by draconian demobilization and a dismantling of the military at the end. ${ }^{36}$ This pattern ceased after World War II. ${ }^{37}$ The impending Cold War presaged an acute and long-term security problem in which the functional imperative gained a permanency and primacy not previously experienced in the United States. To meet the foreseeable long-term threat, Huntington envisaged a large, capable military force, led by a professionalized officer corps. The requirement for a large standing military with a nucleus of professional military leaders put the problematique into stark relief. It forced the question of how to develop and maintain a sizable, competent force, yet avoid endangering the liberal values encased in the societal imperative.

Huntington's societal imperative included a deeply embedded "Lockean" liberal ideology component as well as the structural constant of the US Constitution. ${ }^{38}$ The constant embodied the separation of powers and checks and balances features that created overlapping but often ambiguous responsibilities for ensuring civilian control of the military. The combination of intersecting and imprecise constitutional responsibilities and a fluid security threat compelled American institutions to continuously renegotiate the terms and methods of civilian supervision of the military. For example, Congress exerted control of the military for most of the $19^{\text {th }}$ century simply by authorizing and funding a small regular army and by promoting the decentralized militia system. The Civil War forced Congress to relax these control mechanisms in

\footnotetext{
${ }^{36}$ Huntington, The Soldier and the State, 346.

${ }^{37}$ Huntington labeled this process "extirpation." See Ibid., 155.

${ }^{38}$ Hartz, The Liberal Tradition in America; an Interpretation of American Political Thought Since the Revolution.
} 
order to build an effective Union Army, and the primary civilian control responsibilities were largely transferred to the executive branch. President Lincoln exercised civilian authority by actively orchestrating overall strategy and aggressively replacing unresponsive senior military officers. ${ }^{39}$ Despite constitutional ambiguities that resulted in shifting methods of civilian control, Huntington labeled the Constitution a "constant" because he saw Americans as unwilling to accept any significant alterations to the governing structure regardless of the external threat it faced. ${ }^{40}$

The societal imperative's ideological component embodies American culture's thorough embrace of the liberal principles of individual liberty, property rights, and political representation. Echoing Louis Hartz, Huntington simply argued, "[t]he American knows only liberalism." ${ }^{41}$ Huntington worried that America's attachment to societal imperatives impeded its ability to confront the existential threat presented by the Soviets and to adopt the conservative requirements of the functional imperative. In his calculation, reconciling this imbalance demanded that either the threat dissipate (unlikely), or that "[t]he requisite for military security...[must be]...a shift in basic American values from liberalism to conservatism." ${ }^{42}$

Society's movement toward conservatism would theoretically produce a citizenry more tolerant of military values and, by implication, more acquiescent of military leaders' involvement (and presumably RSOs) in national security policy making. Ensuring civilian control of the military therefore required new institutional control

\footnotetext{
${ }^{39}$ Huntington, The Soldier and the State, 185.

${ }^{40}$ Ibid., chap. 7.

${ }^{41}$ Ibid., 145.

${ }^{42}$ Ibid., 464.
} 
mechanisms. Huntington's Objective Civilian Control model posited a means to concomitantly ensure civilian control, meet the functional imperative, and still maximize liberal values. Objective Civilian Control required that civilian and military leaders each possess autonomous decision-making spheres. ${ }^{43}$ The model prescribed decision-making autonomy for the officer corps in matters related to recruiting, organization, training, tactics, etc., and denounced prying and invasive oversight from civilian leaders, a practice Huntington derogatively referred to as Subjective Civilian Control. ${ }^{44}$ In his framework, military officers would own, "...a distinct sphere of military competence... [not] common to all, or almost all, and which distinguishes them from all, or almost all, civilians." 45

Granting the military decision-making autonomy, however, risked that the officer corps may abuse this grant of power to usurp civilian authority and subvert liberal values. To lessen these risks, in exchange for institutional autonomy the officer corps pledged to abstain from partisan and institutional politics and to epitomize an image of apolitical servants of the state. This institutional quid pro quo, or "bargain," denotes the central theme in Huntington's model. ${ }^{46}$

The concept of military professionalism provided the linchpin for ensuring the success of Objective Civilian Control. ${ }^{47}$ Military professionalism entailed more than technical expertise in the management of violence, a term coined by political scientist Harold Lasswell, but equally important, it embodied an unflinching commitment to the

\footnotetext{
${ }^{43}$ Ibid., 189

${ }^{44}$ Huntington, The Soldier and the State, 84.

${ }^{45}$ Ibid., 3.

${ }^{46}$ Owens, US Civil-military Relations After 9/11.

${ }^{47}$ Huntington, The Soldier and the State, 84.
} 
principle of civilian control of the military. ${ }^{48}$ It also assuaged concerns within civilian society that the highly illiberal ingredients associated with military culture would infiltrate and imperil American liberal values. Despite the incongruities with liberal ideology, civilians would need to accept illiberal ingredients within the military sphere such as coercive discipline, obedience, and a prioritization of the common good over individual interests. Civilian society accepted this trade-off because the professional code of the officer corps assured that these illiberal activities would remain confined to military culture.

In Huntington's conception, norms of military professionalism would also attract highly competent individuals to a career in the officer corps. Military service would appear an attractive option, however, only if society viewed the officer corps as a legitimate and prestigious professional endeavor. Huntington suggested that to elevate the stature of the profession, civilian leaders must grant uniformed military leaders the autonomy to cultivate and implement the practices and traditions necessary to develop martial expertise. In addition, military leaders must have the autonomy to develop a conservative military mind that concomitantly embraced military subservience to civilian control and also remained tolerant of civil society's liberal values. ${ }^{49}$ Autonomy added esteem, and, conversely, it impeded liberal values from infiltrating, or transmuting military culture, which could degrade military readiness. ${ }^{50}$ The disposition

\footnotetext{
${ }^{48}$ Ibid., 74-76.

${ }^{49}$ Ibid., chap. 3.

${ }^{50}$ Ibid., 155. According to Huntington, "transmutation" resulted when civilian leaders meddled and didn't stringently honor the divide.
} 
of the military leader's military mind and professional esteem after leaving the military

was left ambiguous.

Huntington's Objective Civilian Control model made for a parsimonious theory, but critics argued that the basic predictions of the model were not borne out during the Cold War. The U.S. survived the Cold War without making meaningful alterations to its underlying liberal principles, and military officers remained highly professional despite intrusive monitoring from civilian leaders. ${ }^{51}$ Moreover, the presumption of the supremacy of military expertise in wartime decision making also became suspect. Eliot Cohen persuasively argues that modern history is replete with examples where civilian leaders wisely rejected the advice of senior officers on fundamental issues of military strategy, advice that would likely have proven disastrous had civilians deferred to it. ${ }^{52}$ Accompanying the challenges to the predictive power of Huntington's model, the strongest and earliest critiques pointed to an underlying tautology in Huntington's theory: military professionalism leads to strong civilian control, but, conversely, strong

\footnotetext{
${ }^{51}$ Feaver, Armed Servants. Feaver maintains the dichotomous civil-military distinctions in institutional theory but incorporates a rational choice approach. His "Agency Theory" frames the civil-military relationship as one of principle-agent interaction. In Feaver's model, the civilian elite "principles" monitor the military "agent" to ensure it complies with civilian dictates despite incentives to "shirk."

${ }^{52}$ Eliot A. Cohen, Supreme Command : Soldiers, Statesmen, and Leadership in Wartime (New York: Free Press, 2002); Cohen, "The Unequal Dialogue: The Theory and Reality of Civil-Military Relations and the Use of Force." Cohen recognizes a distinct institutional divide but challenges an underlying premise of Huntington's model that assumes military leaders, because of their superior expertise, should be deferred to in matters of war. He uses Lincoln, Clemenceau, Churchill, and Ben-Gurion as examples of intrusive civilian leadership that proved vital to military success rather than as an impediment to it. Cohen argues that while granting deference and autonomy to military leaders during time of war may be prudent on occasion, it cannot substitute as principle (13). Instead, an "unequal dialogue" ought to characterize the relationship. Civilians should value and acknowledge the expertise of generals, but since civilian leaders hold ultimate accountability for the nation's welfare, military leaders must always acquiesce to civilians regardless of the apparent wisdom of their decisions.
} 
civilian control is the indicator of sound military professionalism. ${ }^{53}$ This apparent seam in his model invited military sociologists to consider alternative conceptions of military expertise, culture, and most importantly, military professionalism. It is through this "seam" that the unique position of RSOs as political actors reveals itself.

\section{Sociological Theory in Civil-Military Relations}

In The Professional Soldier (1960), Janowitz acknowledged the theoretical importance of military professionalism, but he directly challenged the notion that distinct civilian and military spheres were necessary to cultivate it. ${ }^{54}$ Rather than $^{2}$ creating a division, Janowitz suggested that the Cold War, particularly the dynamics associated with technology and nuclear weapons, would lead to a convergence of the military and civil society. The massive personnel, technological, and industrial resources needed to counter the Soviet threat made close civil-military cooperation and mutual understanding vital. Military professionalism would therefore entail an ability to be adaptive, intellectually flexible, and socially adept. Janowitz expanded military professionalism from its sole focus on the technical expertise to wage war to a version that required the skills to function in a constabulary role..$^{55}$ The new conception

\footnotetext{
53 Feaver, "The Civil-Military Problematique," 162.

54 Janowitz, The Professional Soldier, a Social and Political Portrait.; Morris Janowitz, Sociology and the Military Establishment (New York: Russell Sage Foundation, 1959).

55 Janowitz describes the constabulary concept as a "radical adaptation of the profession" and becomes manifest when, "...it is continuously prepared to act, committed to the minimum use of force, and seeks viable international relations, rather than victory, because it has incorporated a protective military posture." Janowitz, The Professional Soldier, 418.
} 
elevated the military manager role of the officer corps as a pragmatic rival to Huntington's heroic warrior image. ${ }^{56}$

A constabulary military force, however, blurs civil-military distinctions and risks entangling military professionals in politics. Janowitz recognized this peril and theorized that civilian officials would therefore need to provide more oversight of the military. Constitutional authority over the budget, allocating roles and missions among the services, and structuring how the military communicated information to senior civilian leaders (i.e., the president and congressional leaders), provided some of these oversight tools. ${ }^{57}$ Even with these mechanisms, however, the Constitution's overlapping lines of responsibility leave room for exploitation. The sociological conception of military professionalism did not demand that officers completely abstain from the political process. Instead, it envisaged a more politically astute and broadly educated officer corps that easily integrated with civilian leaders and accepted the overlap of authorities. Janowitz argued, “...it is clear that the professional officer requires considerable sensitivity to the political and social consequences of military operations." ${ }^{158}$ Officers developed with this understanding of military professionalism would not endanger civilian control.

Military sociologists that followed Janowitz claim that their approach "...has never had a clear theoretical or issues-driven center." ${ }^{59}$ Instead, it primarily divides between an internal or external orientation in examining the military as an institution.

\footnotetext{
56 Janowitz, The Professional Soldier, a Social and Political Portrait, 22.

57 Ibid., 364-369.

58 Janowitz, Sociology and the Military Establishment, 96.

${ }^{59}$ Guy L. Siebold, "Core Issues and Theory in Military Sociology," Journal of Political and Military Sociology (Summer 2001): 141.
} 
The Institutional/Occupational, or I/O model, posits whether the military profession better reflects an institutional orientation or an occupational orientation. ${ }^{60}$ An institutional orientation denoted “...a military primarily oriented by its traditions, patriotic values, and sense of community," whereas the occupational referred to a military “...primarily oriented by 'economic man' and general business principles." ${ }^{61}$ The distinction becomes fundamentally important when studying RSOs because it colors perceptions of their status as civilians or as military leaders upon retirement. If the occupational orientation prevails, it becomes much easier to envision RSOs shedding their military outlooks once they reenter the civilian world of business or government. ${ }^{62}$ The institutional orientation implies that the military mind survives the transition back to civil life when officers retire.

Rebecca Schiff's Concordance Model represents a recent attempt to frame the close interactions between the institutional military and civilian leaders, and the model ostensibly leaves some room for considering the RSO. ${ }^{63}$ She argues that since all societies possess different historical and cultural facets, an ideal framework for civil-

\footnotetext{
${ }^{60}$ Charles C. Moskos, "Institutional/Occupational Trends in Armed Forces: An Update," Armed Forces \& Society (April 1986): 377-382.

${ }^{61}$ Siebold, "Core Issues and Theory in Military Sociology," 142.

${ }^{62}$ Sociologists have studied the post-retirement careers of military officers but these early studies only marginally considered the political aspects of employment. An exception is Janowitz who devotes his chapter on "Civilian Alliances" to the interaction of officers and politics. His analysis focuses on the postWar years and finds that the only pattern of RSO employment is diversity. His contribution is discussed further in Chapter 3. See also Albert D. Biderman, "Sequels to a Military Career: The Retired Military Professional," in The New Military, ed. Morris Janowitz (New York: The Russell Sage Foundation, 1964), 287-336; Albert D. Biderman, "Where Do They Go from Here?- Retired Military in America," Annals of the American Academy of Political and Social Science 406 (March 1, 1973): 146-161; Janowitz, The Professional Soldier, a Social and Political Portrait., 18.

${ }^{63}$ Rebecca L. Schiff, The Military and Domestic Politics: A Concordance Theory of Civil-Military Relations (London: Routledge, 2008).
} 
military interaction does not exist. Instead, each nation must develop its own unique partnership among three groups: civilian political elites, the military, and the citizenry. ${ }^{64}$

The interaction of these groups represents a common theme in contemporary civil-military studies, most of which has focused in three issue areas: 1) the "Gap Thesis" which suggests the military has become increasingly estranged from American society, 2) the increased partisan affiliation among officers, particularly in support of the Republican Party, and 3) the level and appropriateness of military influence in policymaking. ${ }^{65}$ The RSO-executive branch relationship touches each of these issue areas but it escapes direct study.

The varied scholarly paths outlined above ultimately rest upon often conflicting principles embedded in liberal-democracy and civic republican ideas. ${ }^{66}$ Liberal theories of democracy, perhaps paradoxically, coexist best with Huntington's model of Objective Civilian Control. For example, if the military exists solely to protect and defend national territory so liberal-democratic values like individualism, property rights, and civil

\footnotetext{
${ }^{64}$ Schiff's empirical research, however, focuses heavily on historical occurrences of coups d'etat which limit the model's usefulness in studying the American case.

${ }^{65}$ Richard D. Jr. Hooker, "Soldiers of the State: Reconsidering American Civil-Military Relations," Parameters (Winter /2004 2003): 4-18; Thomas E. Ricks, "The Widening Gap Between Military and Society," The Atlantic, July 1997, http://www.theatlantic.com/magazine/archive/1997/07/the-wideninggap-between-military-and-society/6158/; Richard M. Jr. Wrona, "A Dangerous Separation: The Schism Between the American Society and Its Military," World Affairs 169, no. 1 (2006): 25-38; Ole R. Holsti, "A Widening Gap Between the U.S. Military and Civilian Society?: Some Evidence, 1976-96," International Security 23, no. 3 (1998): 5-42; Lance Betros, "Political Partisanship and the Military Ethic in America," Armed Forces \& Society (Summer 2001): 501-523; Andrew J. Bacevich and Richard H. Kohn, "Grand Army of the Republicans: Has the U.S. Military Become a Partisan Force?," The New Republic (December 8, 1997): 22-25; Brooks, "Militaries and Political Activity in Democracies"; Michael C. Desch, "Bush and the Generals," Foreign Affairs (June 2007): 97-108; Richard B. Myers et al., "Salute and Disobey?," Foreign Affairs, September 1, 2007, http://www.foreignaffairs.com/articles/62843/richard-b-myers-and-richardh-kohn-mackubin-thomas-owens-lawrenc/salute-and-disobey.

${ }^{66}$ Burk, "Theories of Democratic Civil-Military Relations."
} 
liberties can flourish, then the stark division between military culture and civilian society seems justifiable. In this case, the military reflects a necessary island of conservatism that is tolerated within a sea of Lockean liberalism. A civic-republican conception of democracy, however, makes this stark division less tenable and less desirable. This orientation recognizes military service as a civic duty, and civilian control of the military relies directly on how closely the military resembles the values and demographics of civil society. ${ }^{67}$ Civic-republican ideas also envisage active engagement in politics as a basic responsibility of citizenship. Scholar James Burk notes that civic participation not only produces civic virtue, but also prevents military usurpation: “...participation in public life ensures the continuation of the community as a republic; when citizen participation flags, the republic becomes corrupt. In addition, when citizens serve as soldiers to defend the republic, the interests of the military and the interests of the state overlap, and there is no reason to fear a military challenge to the republic." ${ }^{68}$ Views on the appropriateness of RSOs in executive branch are therefore colored by different understandings of liberalism and civic-republican ideas; one that views excluding RSOs in politics as a necessary sacrifice to protect liberal values in the broader society, while the other view finds a necessary civic-republican virtue in their participation.

With civil-military relations theory stripped to its core issue, the question posed at the beginning of the discussion must again be asked: where does the RSO-executive branch relationship fit into existing theory? Neither the institutional nor the sociological framework provides a clear answer. Institutional theory ostensibly provides only two

\footnotetext{
${ }^{67}$ Owens, US Civil-military Relations After 9/11, 24.

${ }^{68}$ Burk, "Theories of Democratic Civil-Military Relations," 10-11.
} 
alternatives: 1) RSOs return to true civilian status, and enjoy the associated privileges and responsibilities shared by all fellow democratic citizens. In this case, their service in the executive branch presents little concern. Or, 2) the deeply inculcated norms implied in military professionalism make RSOs distinctly different types of citizens whose ideological orientations are in tension with liberal-democratic society and therefore present real risks to democratic politics. ${ }^{69}$ If the latter depiction reflects reality, then military colonization potentially entails serious consequences for democratic government. It portends that the wolf may be guarding the chicken coup.

On the other hand, sociological orientations too easily dismiss civil-military distinctions. Military family members, defense contractors, veterans etc., maintain unique relationships to the armed forces via involvement in interest groups, advisory roles, lobbying, supply contracting, etc., which makes them different from other civilians. In the particular case of RSOs, military sociology ostensibly recognizes the civic-republican advantages of executive branch service but discounts the important traits of former military officers RSOs that may make their participation problematic.

Scholar Philip Meilinger contends that the image of a permeable membrane therefore best describes the civil-military relationship. ${ }^{70}$ This image provides a helpful compromise between civil-military relations theories and it also gives an opening to situate the RSO. A permeable membrane recognizes division but tolerates cross-over interactions. However, it also invites other questions: what policy making functions

\footnotetext{
${ }^{69}$ Schiff, The Military and Domestic Politics, 47. Schiff broadly labels civ-mil theories that follow the Huntington dichotomy as "Separation Theory."

${ }^{70}$ Phillip S. Meilinger, "Soldiers and Politics: Exposing Some Myths," Parameters (Summer 2010): 74-86.
} 
fluidly move between spheres, why does this dynamic occur, how and which political actors or institutional structures impede or propagate this dynamic, and when does this interaction endanger healthy civil-military relationships? RSOs reside in this permeable membrane and their relationship to the executive branch directly impacts the answers to these questions.

With the theoretical void identified, the second prerequisite to unveiling the RSO-executive branch relationship categories now requires attention. So what if extant research does not specifically address RSOs? Is this void meaningful? What are the particular traits that make RSOs worthy of unique political consideration? In short, do RSOs really matter in American politics?

\section{The RSO as a Unique Political Actor}

RSOs possess unique and politically relevant traits that are best described using these four broad labels: 1) Prestige, 2) Career Structure, 3) Institutional Mindset, and 4) Political Image. Other professionals or political elites may share some or all of the traits and attributes contained within these categories, but RSOs possess them in distinctive arrangements which make these individuals intriguing subjects for political analysis. The traits embedded in these categories contain both positive and negative dimensions in relation to the RSO-executive branch interaction.

\section{1) Prestige}


In Democracy in America, Tocqueville notes: "[t]here is no greatness that satisfies the imagination of a democratic people more than military greatness-brilliant and sudden greatness obtained without work, by risking only one's life." ${ }^{71}$ The Frenchman's quote captures a curious and ancient trait of most human societies: the prestige afforded to the image of the heroic military leader and the virtues they putatively symbolize. In an early civil-military study, The Man on Horseback: The Role of the Military in Politics (1962), scholar S.E. Finer expounds on this theme:

These virtues-bravery, discipline, obedience, self-abnegation, poverty, patriotism, and the like-are associated, by long standing, with the soldier's choice of career. They are values which all esteem. Where they are identified with the military, these acquire a moral halo which is politically of profound importance...[f]rom this there arises, at the lowest, a sympathy for the armed forces; at its highest a veritable mystique.." ${ }^{72}$

Despite our nation's ostensible antimilitaristic culture, Americans have embraced this veritable mystique and have held senior military figures in high-esteem throughout most of the nation's history. ${ }^{73}$ The number of American military heroes who were either elected president or a served as major party candidates stands as a significant reminder of this penchant. ${ }^{74}$ Electing prominent military heroes to the presidency seemingly contrasts with the founding American principles routinely taught in elementary school civics: e.g., the notion that Americans innately fear military tyranny and therefore the Founders created strong institutional barriers to prevent the rise of a military hero turned political despot. The prevalence of military heroes in presidential electoral

\footnotetext{
${ }^{71}$ Tocqueville, Democracy in America, 629.

${ }^{72}$ Finer, The Man on Horseback; the Role of the Military in Politics., 10-11.

${ }^{73}$ Arthur Ekirch Jr., The Civilian and the Military: A History of the American Anti-Militarist Tradition, 2nd ed. (Oakland, CA: Independent Institute, 2010); Huntington, The Soldier and the State, chap. 6.

${ }^{74}$ Albert Somit, "The Military Hero as Presidential Candidate," The Public Opinion Quarterly 12 (July 1, 1948): 192-200.
} 
politics suggests that Americans accept a continuing political role for former military officers despite their ostensible opposition to militarism.

The noteworthy number of military presidents enlivens discussions on the political value of being viewed as a military hero, but a focus on this unique group of RSO presidents does not fully capture the extent to which American culture broadly imputes prestige to all RSOs. American society has traditionally granted significant social prestige to RSOs but in a historical pattern that ebbs and flows. The contrast between the current social environment and the post-Vietnam environment exemplifies this inconsistency. Despite the fluctuations in the social prestige, the military officers have consistently and publically identified themselves with their rank long after retirement, and the American public appears to recognize and embrace an enduring relevance to one's former military status. ${ }^{75}$ For example, the national media regularly underscores the rank of RSOs when they serve as expert commentators, reinforcing the notion that military rank somehow confers professional relevance long after retirement. Moreover, even in Senate confirmation hearings for high-level civilian appointments, legislative leaders routinely address RSOs by their former military rank, ostensibly unconcerned with the submerged tensions inherent in the courtesy.

RSOs are not alone among professionals in retaining their former appellations. Society confers the same honor to doctors, professors, congressmen, judges, etc. However, RSO titles and other professional styles embody substantive differences.

\footnotetext{
${ }^{75}$ Golby, Dropp, and Feaver, Military Campaigns: Veterans' Endorsements and Presidential Elections. This study finds that when individuals are told that an RSO supports a particular candidate, that individual is more likely to respond with a favorable assessment of the candidate compared to those not told of the endorsement.
} 
Whereas the title of doctor or professor affirms a medical expertise or intellectual expertise respectively, the title of "General" or "Admiral" arguably conjures up more visceral images of command and leadership, traits often viewed as innate. As a consequence, military titles infer a competency viewed less fleeting or less perishable than other professions. Moreover, whereas media introductions such as former Secretary of the Treasury or former Chairman of the Federal Reserve appear commonplace, the titles of former General or former Admiral sound almost oxymoronic. The democratic roots of the American military officer corps arguably add to the cultural prestige of RSOs. The American military has at times revealed vestiges of old world aristocracy, ${ }^{76}$ but Americans predominantly recognize the egalitarian characteristics of military service and view it as a vehicle for upward social mobility. ${ }^{77}$ Senior US military officers putatively represent exemplars of individual initiative, technical competence, and patriotism, rather than recipients of titles by birthright. The advent of the All-Volunteer Force (AVF) perhaps undermined some of these democratic traits, but even so, few perceive the modern officer corps as a bastion of upper class privilege. $^{78}$ As the 2012 presidential campaign highlighted, Americans do not look favorably upon perceptions of inherited privilege in politics; RSOs maintain an elevated

\footnotetext{
${ }^{76}$ Janowitz, The Professional Soldier, a Social and Political Portrait., chap. 5.

${ }^{77}$ For short overview of social history of US military see Carl Reardon, "View From the Ranks: The Social and Cultural History of the American Armed Forces," OAH: Magazine of History (October 2008): 11-16.

${ }^{78}$ Although an increasing proportion of the officer corps now comes from the upper quartile, I maintain that the dominant perception of the Armed Forces is not one of privilege. See Shanea Watkins and James Sherk, Who Serves in the U.S. Military? The Demographics of Enlisted Troops and Officers (Washington D.C.: Heritage Foundation: Center for Data Analysis, August 21, 2008), http://www.heritage.org/research/reports/2008/08/who-serves-in-the-us-military-the-demographics-ofenlisted-troops-and-officers.
} 
social status without having to face the "privilege" conundrum associated with inherited wealth or even corporate success.

Federal statutes also serve to codify a continued significance for rank among retired officers. In retirement RSOs remain part of the military in an inactive status and can be recalled if needed. ${ }^{79}$ Related to the status of military retirees, the Supreme Court concluded, “...military retired pay is reduced compensation for reduced current services," indicating continued military responsibilities although not defining the nature of these duties. ${ }^{80}$ Additionally, RSOs fall within the jurisdiction of the military judicial system, the Uniformed Code of Military Justice (UCMJ), which can prosecute them for offenses not applicable to their civilian counterparts. ${ }^{81}$ For example, Article 88 of the UCMJ specifically prohibits contemptuous speech directed at the President and Vice President. Such provisions rarely result in a retired officer being court-martialed, but they do provide another indication that RSOs hold a somewhat vague status between military and civil societies. ${ }^{82}$

The cultural and professional prestige of RSOs can also produce negative implications for democratic governance. For instance, RSO prestige encourages political

\footnotetext{
${ }^{79}$ See 10 U.S.C $§ 688$

${ }^{80}$ McCarty v. McCarty, 453 U.S. 210, 222 (1981)

${ }^{81}$ For an excellent legal overview on legal provisions pertaining to retired military officers and the UCMJ, see Lieutenant Colonel (Ret.) J. Mackey Ives \& Lieutenant Colonel (Ret.) Michael J. Davidson, "CourtMartial Jurisdiction over Retirees Under Articles 2(4) and 2(6): Time to Lighten Up and Tighten Up," Military Law Review, Vol 175, March 2003. http://www.loc.gov/rr/frd/Military Law/Military Law Review/pdf-files/175-03-2003.pdf.

${ }^{82}$ Only one such retiree court-martial occurred for the offense of contemptuous speech and the accused was acquitted. This particular case resulted from an Army musician that accused President Wilson and his administration of being "subservient to capitalists and 'fools to think they can make a soldier out of a man in three months and an officer in six." Michael J. Davidson, "Contemptuous Speech against the President, “Army Lawyer (July 1999), 1,4, note 41.
} 
actors to solicit the support of former senior military officers and to seek close and visible public relationships with them. A politician's desire for RSO favor may in turn make these civilian leaders more hesitant to challenge military preferences, not just in matters of war and peace, but also on issues related to pay, retirement benefits, etc. The generalized prestige granted to RSOs by the American public also masks distinctions in the professional specialties of senior military officers. The title of "general" or "admiral" automatically infers competency in broader facets of military or geopolitical strategy even though most RSOs, especially former one-star and two-star officers, may have little experience in addressing international or domestic political issues. Cultural prestige may infer competencies that RSOs simply don't have and grant political agency based solely on romanticized images of the warrior-statesman.

The unique cultural and professional prestige granted to RSOs therefore entails both positive and negative implications for democratic politics. Both sides of this dualedged sword must remain in focus when considering the RSO-executive branch relationship.

\section{2) Career Structure}

As military officers, RSOs served in an organizational structure decisively different from nearly all civil systems in the private sector or the government. Three particular components of this structure require emphasis: 1) the military's hierarchical rank and promotion system, 2) the military retirement system, and 3) the acculturation process that occurs during a military career. These characteristics shape the 
professional development of RSOs and influence their views on post-retirement professional options and their relationship to executive branch politics.

The rigid hierarchical structure is the most noticeable and distinct characteristic of military organizations. The structure not only delineates superior-subordinate relationships but also outlines a comparatively clear path for advancement. The latter feature ensures that all RSOs plod through the ranks of lowly lieutenant, or captain, or possibly even the enlisted ranks, on their way to the elite position of general or admiral. Simply put, senior military officers are not "hired from outside the company," but instead they are developed organically. ${ }^{83}$ As a consequence, reaching the top military ranks requires a long, uninterrupted career within the same organization.

In $19^{\text {th }}$ and early $20^{\text {th }}$ century America, a lawyer, doctor, or senator could take up arms in a national emergency, advocate for an officer's commission, and then immediately return to private life when the threat subsided. The current professionalized all-volunteer military affords no such opportunities. The officer profession putatively demands unique technical expertise in waging modern war, an expertise that the amateur patriot politician or business leader does not have and cannot readily develop. ${ }^{84}$ In contrast to military careers, senior civilian government leaders routinely shuttle between executive administrations and Congress, K Street,

\footnotetext{
${ }^{83}$ For some career specialties such as medical professionals, lawyers, and military chaplains, individuals do not necessarily enter the military at its most junior rank. However, professionals in these career fields are also promoted separately from other "line" officers and are not considered for operational command positions.

${ }^{84}$ The veracity of claims that only military officers possess the skills and expertise to manage modern war is rather tenuous. For an historical account that challenges the unique war-making expertise of military officers visa vie civilian leaders, see Eliot A. Cohen, Supreme Command : Soldiers, Statesmen, and Leadership in Wartime / (New York : Free Press, 2002), http://search.lib.virginia.edu/catalog/u3862050.
} 
academia, Wall Street, and even Main Street, but temporary stops in a senior uniformed military position remain unthinkable.

An officer's commitment to a long uninterrupted career does not, however, mean the G/FO ranks await all those who endure. The "up or out" promotion system denies continued service for those not selected for higher rank. The number of years of service determines an officer's promotion "window," and if not selected for advancement within that window, in practice essentially a one-shot opportunity, the officer must separate from the armed forces or retire if eligible. Lateral career moves do not exist and neither can an officer opt to remain stagnant in rank. The career paths walked by RSOs therefore reflect not just endurance, but also survival in a highly competitive and selective process. ${ }^{85}$

Table 2.1 below provides some perspective on the steep rank hierarchy in the military and shows the few number of officers who reach the G/FO ranks. The "percent" column represents the number of officers of a respective rank as a percentage of all active duty officers. Currently, officers comprise roughly $15 \%$ of the active force.

\footnotetext{
${ }^{85}$ See Thomas E. Ricks, The Generals: American Military Command from World War Il to Today (New York: The Penguin Press, 2012). Ricks provides a rich history of the post-World War II changes in the way that general officers are both hired and fired. He argues that many of these features of the promotion system actually contribute to a diminution in leadership competencies among RSOs. Ricks shows that in the years following World War II, delayed promotions or certain leadership failures were often accompanied by reassignment, rehabilitation, and then second opportunities, rather than dismissal. In the current system, Ricks suggests that the unforgiving nature of the promotion system may impeded innovation and exacerbate conformity.
} 
Table 2-1: Rank Distribution of the United States Active-Duty Military

\begin{tabular}{|llll|}
\hline Rank & Grade & Strength & Percent \\
\hline General/Admiral & $0-10$ & 38 & .018 \\
Lieutenant General/Vice-Admiral & $0-9$ & 149 & .069 \\
Major General/Rear-Admiral & $0-8$ & 311 & .1 \\
Brigadier General/Rear-Admiral (lower) & $0-7$ & 447 & .21 \\
Colonel/Captain & $0-6$ & 12,223 & 5.7 \\
Lt Colonel/Commander & $0-5$ & 29,127 & 13.5 \\
Major/Lieutenant Commander & $0-4$ & 46,244 & 21.4 \\
Captain/Lieutenant & $0-3$ & 73,414 & 33.9 \\
First Lieutenant/Lieutenant Junior Grade & $0-2$ & 30,573 & 14.1 \\
Second Lieutenant/Ensign & $0-1$ & 23,791 & 11 \\
& & & \\
Total Officers & & 216,317 & \\
& & & \\
Warrant Officers & W1-5 & 19,706 & \\
Enlisted Personnel & E1-9 & $1,160,611$ & \\
Total Active Force & & & \\
US Department of Defense (2012) ${ }^{86}$ & & & \\
\hline
\end{tabular}

The clearly defined and competitive career path solidifies strong organizational

norms for advancement. The institutionalized advancement process expedites the most talented officers yet still in a step-wise and transparent way. Certain positions and experiences become known as prerequisites for future promotions and are coveted and pursued. Senior military leaders identify and groom promising officers early and elevate them to the senior ranks rapidly but still along a predictable experiential track. This system produces two important consequences related to RSOs: 1) they share somewhat homogenized leadership experiences, and 2) because they are identified as promising

\footnotetext{
${ }^{86}$ U.S. Department of Defense, Personnel and Procurement Statistics: Personnel and Procurement Data Files. http:// http://siadapp.dmdc.osd.mil/ accessed 22 August 2012. Data current as of 31 March 2012. The "rank" column includes differences in the naming conventions for officer ranks; the Navy rank identifiers differ from the other services but they are equivalent in status. Therefore, when speaking of officer ranks it is common to refer to "grade" (i.e., "O-7" for Brigadier General \& Rear-Admiral (lower)) which signifies officers of comparable rank across the services. The "Rank" vs. "Grade" distinction carries additional meaning regarding pay entitlements however this aspect of the distinction is not relevant for this comparison.
} 
officers early in their careers, RSOs reach the highest ranks rapidly and spend over onethird of their military careers as G/FOs. RSO status therefore signifies at least a decade, likely two, of high-level executive experience.

The career structure's insularity also produces unique and important consequences for the development of RSO traits. Unlike other executive positions where a wider pool of potential nominees in business, academia, or state government can be considered, senior civilian officials promote three and four-star G/FOs from a small and finite group. As a result G/FO appointments do not contain all different walks of life or highly divergent experiences and expertise. Furthermore, G/FOs at the three and four-star ranks represent a very well-acquainted group of individuals. Many officers, for instance service academy graduates, likely have known each other their entire adult lives, shared common assignments, and possibly even combat experiences. This close familiarity among senior military leaders invites scrutiny of both the positive and negative implications for RSO participation in the executive branch.

The military retirement system reflects another distinctive factor related to RSO traits. The military retirement system enables $\mathrm{G} / \mathrm{FO}$ s to retire at a relatively young age and with productive years left to pursue significant post-military careers. Military pension benefits are payable immediately upon retirement regardless of age so, for some military officers, these entitlements begin at the age $41-42$, possibly even younger ${ }^{87}$ The average retirement age for all ranks of G/FOs is 56 years old, and even

\footnotetext{
${ }^{87}$ This determination is based on the requirement for 20 years of service before retirement. Since officers require a 4-year degree for entry, their active service would typically not begin until roughly the age of 22 , whereas enlisted members could enter as early as 17. A 2012 CRS study reports that the average
} 
among those who attain the four-star rank, the average increases only to $58 .^{88}$ As a comparison with other professional executives, a 2007 study calculated the median age of CEOs in S\&P 500 companies to be 55, demonstrating that RSOs retire at the prime executive leadership point in the corporate world. ${ }^{89}$

In addition to the early retirement age, RSO pension benefits are relatively generous and likely influence post-retirement options. A 2004 GAO report documented that one-star G/FOs served an average of 26 years prior to reaching the G/FO ranks and served 33.5 years before retirement. The average jumps to 35 years of service for those who retire with four stars. ${ }^{90}$ Statutes currently cap G/FO pay at $\$ 179,701$ annually, but other entitlements add potentially thousands more annually in dollar value. ${ }^{91}$ Based on the 2012 DOD pay tables, a four-star G/FO retiring with 38 years of service would receive an annual pension of around $\$ 215,000$ and a retiring three-star officer with roughly 35 years of service would earn approximately $\$ 170,000 .^{92}$ Recent legislation enables long-serving G/FOs to earn more in retirement than they did on active-duty. Military members that retire with 20 years of service become entitled to a retirement

retirement age \& time of service at retirement for enlisted members is 43 and 22 years respectively, whereas for officers the ages are 45 and 24 on average. See Congressional Research Service Report: Military Retirements: Background and Recent Developments. 27 March 2012. http://web.lexisnexis.com/congcomp/attachment/a.pdf?_m=b2daa5997c0b1551eb6484ef675d10e1\&wchp=dGLbVzkzSkSA\&_md5=5512d87ab43a0c4e19ce9eff09cf722d\&ie=a.pdf

${ }^{88}$ Ibid., pp. 3.

89 Del Jones, "Does Age Matter When You're CEO?," USATODAY.COM, September 11, 2008, http://usatoday30.usatoday.com/money/companies/management/2008-08-12-obama-mccain-ageceos_N.htm.

${ }^{90}$ U.S. Government Accountability Office, Report to Congressional Committees. 2004. Military Personnel: DOD Could Make Greater Use of Existing Legislative Authority to Manage General and Flag Officer Careers. September, 2004. http://www.gao.gov/products/GAO-04-1003

${ }^{91}$ Such monetary entitlements include housing allowance, subsistence; non-monetary retirement benefits such as commissary privileges, use of military base facilities such as fitness centers etc. are also significant benefits but not expressly addressed in this analysis.

${ }^{92}$ See DOD Military Basic Pay Tables: effective 1 January 2012 http://www.dfas.mil/militarymembers/payentitlements/militarypaytables.html 
benefit of $50 \%$ of their base pay and $2.5 \%$ more for every year beyond 20 . Until 2007 , statutes capped military retirement pay at $75 \%$ of base pay regardless of tenure. ${ }^{93}$ The 2007 legislation removed this cap, however, allowing officers who remain 40 years, as some four-stars do, to earn over $100 \%$ of their active-duty salary.

The data above reflects only some rough averages and speculating on the individual wealth or standard of living aspirations these officers have remains impossible. Nonetheless these figures do demonstrate that RSOs likely achieve a level of financial independence at a relatively young retirement age. This feature of their career structure allows them some flexibility about what future opportunities they pursue.

The last unique component in the military career structure category, the acculturation process, is also the most important. Regardless of rank, even those who served short tours in the military and later achieved significant professional success in other civil endeavors still reflect on the strong impact military service had on their lives. Two well-known American political figures represent the many possible illustrations of this factor: General Dwight Eisenhower and Senate Majority leader and Ambassador Mike Mansfield. Senator Mansfield served from 1919-1922 in the United States Marines, but despite achievements as an academic, businessman, and as a highlyrespected political leader, his head stone at Arlington National Cemetery simply reads: “PVT, US Marine Corps." ${ }^{94}$ Likewise, President Eisenhower specified that he be buried in

\footnotetext{
${ }^{93}$ See National Defense Authorization Act for Fiscal Year 2007.

${ }^{94}$ Don Oberdorfer, Senator Mansfield: The Extraordinary Life of a Great American Statesman and Diplomat (Washington DC: Smithsonian Books, 2003), 309.
} 
his Ike Army jacket, unadorned of ribbons or medals, and laid in state in the standardissue eighty-dollar Army coffin; the same type that thousands of his former soldiers rested in. ${ }^{95}$ Despite two popular terms as president, in the end, Ike still wanted to be remembered as a soldier.

\section{3) Institutional Mindset}

In On Thinking Institutionally, political scientist Hugh Heclo contrasts thinking about institutions and thinking institutionally. ${ }^{96}$ Heclo argues that thinking institutionally reflects a "stance" or "appreciative viewpoint," or more precisely, "...a bent in one's disposition, something more socially conditioned than a personal preference but not so tightly structured as to render the individual a mere carrier of predetermined social norms." ${ }^{97}$ Institutional thinking reflects one's deep moral acceptance of an obligation to the purpose of an institution itself. ${ }^{98}$ Considering oneself part of any profession demonstrates at least some acknowledgement of an obligation to think institutionally. However, the characteristics of military careers that culminate in the G/FO ranks arguably inculcate an ability and willingness to think institutionally like few other professions.

For G/FOs, institutional thinking does not solely result from idealized notions of unwavering devotions to service above self, duty, or patriotic fervor. These notions are no doubt significant motivators for officers, but thinking institutionally also promotes a

\footnotetext{
${ }^{95}$ Smith, Eisenhower in War and Peace, 765.

${ }^{96}$ Hugh Heclo, On Thinking Institutionally (New York: Oxford University Press, 2008).

${ }^{97}$ Ibid., 81.

${ }^{98}$ Ibid., 85.
} 
more self-serving objective: the goal of maintaining and perpetuating one's own public prestige as an RSO. Some simple and reasonable assumptions undergird this point. First, RSOs assumedly value the public prestige their military titles confer upon them and want to maintain it. Second, RSOs recognize the inextricable linkage between their own personal prestige and the broader reputation of the institutional military. The public arguably perceives much greater group homogeneity among G/FOs than it does among professional leaders in, for instance, medicine, academics, or law. Whereas the public recognizes and understands distinctions between doctors like cardiologists and ophthalmologists, or between academics like historians and research scientists, distinctions between types of general officers such as "logistics" generals, "intelligence" generals or "staff" generals are not commonly made by citizens. As their titles imply, they are simply understood as "generalists." ${ }^{99}$ This distinction between professions is important because it contributes to how the public perceives the professional competencies of RSOs and how these competencies relate to the political world.

Few RSOs will achieve public renown for applying their professional expertise in a heroic manner such as leading large troop formations, directing mass sea battles or strategic bombing campaigns. Therefore, their own reputations relate closely to the prestige of the military profession as a whole. For instance, a publicized miscue by someone active in the legal, medical, or academic profession diminishes to some degree the prestige of the entire profession. But because the public recognizes finer distinctions within these professions, and they have more personal interaction with the

\footnotetext{
99 Peter J. Roman and David Tarr, "The Joint Chiefs of Staff: From Service Parochialism to Jointness," Political Science Quarterly 113, no. 1 (1998): 406.
} 
individuals that comprise them, the miscue will likely cause less damage to the overall profession than do transgressions by G/FOs. If a significant failure by active-duty military leaders discredits the military, RSOs have much less ability to protect their own individual titular prestige. They likely lack personal heroic accomplishments, and their greatest and most lasting achievements are likely organizational, administrative or procurement successes. While these efforts contribute to the country's long-term national security, they invoke much less individual public acclaim and cannot serve as the foundation for their own public prestige as a military officer. In short, the public reputation of the current institution determines RSO prestige much more so than with other professions.

Recent research on the Military Model for developing leaders supports the assumptions regarding the ability of G/FOs to think institutionally. ${ }^{100}$ In response to the scathing 2003 Volker Commission report, Urgent Business for America: Revitalizing the Federal Government for the $21^{\text {st }}$ Century, the RAND corporation assessed a key finding in the report that noted a lack of high-level leadership competencies in the public sector. ${ }^{101}$ The report compared the Military Model against a wide array of alternatives and found the military program superior in developing these skills. Al Robbert, the author of one RAND study, argued that senior leaders must be competent operating within environments characterized by organizational autonomy, large spans of control, and

\footnotetext{
${ }^{100}$ Al Robbert, "Developing Leadership: Emulating the Military Model," in High-Performance Government: Leadership, Structure, Incentives, ed. R. Klitgaard and P.C. Light (Santa Monica, CA: RAND Corporation, 2005), 255-281, http://www.rand.org/content/dam/rand/pubs/monographs/2005/RAND_MG256.pdf. ${ }^{101}$ Volcker Commission, Urgent Business for America: Revitalizing the Federal Government for the 21st Century (National Commission on the Public Service, January 4, 2003), http://ourpublicservice.org/OPS/publications/viewcontentdetails. php?id=92.
} 
geographic separation. ${ }^{102}$ The RAND study also emphasized the requirement of a broad international perspective for American public leadership in the $21^{\text {st }}$ century. The study cited the military model as better designed to produce leaders with such skills and perspectives. Even relatively junior military officers are required to lead in environments with these traits, developing increased proficiency during their climb in rank. Overall, RAND concluded that the military model devotes more time and resources than alternative programs into developing competencies to meet these institutional leadership demands.

Budgetary, organizational, and cultural differences in institutions make it impractical or even undesirable for the civilian public sector to adopt all facets of the military's leadership development model. However, studies like the RAND effort support assertions that RSOs develop valuable leadership attributes, including an ability to think institutionally, that transfer well to other spheres of public leadership. The military's leadership development system produces broad managerial capabilities that transcend the narrower technical expertise required for the management of violence, and instead build competency in broader institutional-minded leadership. ${ }^{103}$

Certain forms of institutional mindedness can, however, manifest negative consequences in the RSO-executive branch relationship. An unbending concern for the reputation of an institution can produce a culture that inhibits outside critique, avoids institutional self-reflection, and suppresses confessions of its own shortcomings and failures. Cultural norms that prioritize protecting institutional reputations invariably

\footnotetext{
${ }^{102}$ Robbert, "Developing Leadership: Emulating the Military Model," 256.

${ }^{103}$ Term coined by Harold Lasswell as quoted in Huntington, The Soldier and the State, 11.
} 
produce an internal promotion calculus that ultimately dissuades real institutional thinking. Institutional thinking may morph into an undue concern for the perceived reputation of an institution at the expense of its true long-term institutional health and success. $^{104}$

\section{4) Political Image}

The last category of RSO traits that makes them unique political actors relates to their politically transcendent image. Paradoxically, the arguably apolitical images of figures such as George Marshall, Dwight Eisenhower, Colin Powell, and David Petraeus are in turn what make them so politically relevant. Notwithstanding their transcendent images, military officers inherently convey political statements in actions as simple as swearing allegiance to the Constitution, demonstrating visible subordination to democratically elected leaders, or even just wearing the uniform. Active officers and RSOs are also American citizens, and therefore they maintain the right and responsibility to participate in the democratic process. Members of the military vote, contribute to candidate campaigns, and attend political meetings. ${ }^{105}$ Despite their personal political leanings, however, legal and professional obligations demand that active officers provide expert and timely advice to civilian leaders irrespective of the partisan or

\footnotetext{
${ }^{104}$ See Ricks, The Generals. Ricks suggests that the unforgiving nature of the current G/FO system combined with an overriding concern for institutional reputation may be responsible for producing officers less likely to think creatively about the grander issue of national security and military policy. ${ }^{105}$ U.S. Department of Defense Directive Number 1344.10, February $19^{\text {th }} 2008$, “Political Activities of the Members of the Armed Forces" outlines current guidance for military members with respect to political participation. Regarding partisanship, members are allowed to join partisan groups and attend meetings but are expressly prohibited from making political speeches or fundraising for these groups regardless of whether in uniform or not. http://www.dtic.mil/whs/directives/corres/pdf/134410p.pdfs
} 
political implications and they refrain from public displays of partisanship. Theoretically, this expert advice would pertain to purely military matters. In practice, however, many contentious issues force military leaders into the political sphere because the disputes directly impact the health, readiness, and morale of the military they are charged to lead. Lifting the ban on homosexuals in the armed forces provides a poignant example. The conflict served as a proxy for the broader national debate on homosexual rights, but it nonetheless thrust senior military leaders, most prominently Colin Powell, into a volatile social and political dispute. ${ }^{106}$ Powell, arguably the most "political" general of the last three decades, acknowledged the unrealistic expectations that active military leaders can completely abstain from politics: ${ }^{107}$

...a great deal of my time is spent sensing the political environment. People sometimes say, '...well, Powell, he's a political general anyway.' The fact of the matter is there isn't a general in Washington who isn't political, not if he's going to be successful, because that's the nature of our system. It's the way the Department of Defense works. It's the way in which we formulate foreign policy. It's the way in which we get approval for our policy. ${ }^{108}$

In an oral history discussion of his tenure as Chairman of the Joint Chiefs, however,

Powell explained this type of behavior does not detract from civilian control of the military as often suggested:

...I was considered a very active, aggressive chairman using the powers of Goldwater-Nichols. That's what it said in the literature. What thinking people sometimes don't understand is that Goldwater-Nichols gave me nothing that Cheney didn't want me to have. And so I was empowered not by Goldwater and Nichols but by Dick Cheney to be his partner in helping him run the Pentagon.

\footnotetext{
${ }^{106}$ Elizabeth Bumiller, “Top Defense Officials Seek to End 'Don't Ask, Don't Tell'," The New York Times, February 2, 2010, Online edition, http:www.nytimes.com/2010/02/03/us/politics/03military.html. ${ }^{107}$ See Steven Lee Myers, "Generally Speaking," The New York Times, April 6, 2008, sec. Week in Review, http://www.nytimes.com/2008/04/06/weekinreview/06myers.html. In this article defense scholar Lawrence Korb labels Powell, "the most political general since Douglas MacArthur."

${ }^{108}$ Bob Woodward, The Commanders (New York: Simon \& Schuster,, 1991), 55.
} 
Nothing in the law said he had to listen to my advice, had to hear it if he didn't want to, or couldn't take his advice from the guard at the desk. So it created a process for what really makes the process work-this personal relationship between the people. ${ }^{109}$

Powell's perceptions and his public role in the homosexual debate admittedly relate to the political actions of an active senior military leader. Nonetheless, actions by active officers likely influence their public images later as RSOs which then invites questions about their appropriate role in retirement. In 2006, for example, a group of RSOs publically denounced Secretary of Defense Donald Rumsfeld for his wartime leadership decisions, and their comments ignited a debate over the professional responsibilities of RSOs in relation to the American political system. ${ }^{110}$ The ensuing discussion demonstrated America's ambivalence about RSO political behavior. On one hand, critics disapproved of the group's actions against Rumsfeld, claiming that they put undue strain on the image of transcendent politics and the trust relationship between administration officials and active leaders. ${ }^{111}$ Alternatively, the image of transcendent politics is exactly what made the RSO opposition so credible and salient to the American public.

As Powell's earlier quote indicated, G/FOs cannot be completely removed from politics. However, the public perception of military officers as above politics still largely

\footnotetext{
109 Ivo H. Daalder, I. M. Destler, and Karla J. Nieting, The National Security Council Project: Oral History Roundtables: The Role of the National Security Adviser (Washington, DC: The Brookings Institution, October 25, 1999), 56, http://www.brookings.edu/ /media/Projects/nsc/19991025.PDF.

${ }^{110}$ For example, see PBS interviews with members of this group and Secretary Rumsfeld at http://www.pbs.org/newshour/bb/military/jan-june06/iraq 4-13.html

${ }^{111}$ See Bruce Ackerman, The Decline and Fall of the American Republic (Cambridge, Mass: Belknap Press of Harvard University Press, 2010), 60; For an argument that suggests RSOs should be discouraged from this form of political participation see Brooks, "Militaries and Political Activity in Democracies."
} 
prevails in the United States. Military leaders and RSOs recognize the value of this apolitical image to institutional prestige, credibility and public trust, and therefore they work to cultivate and nourish this image. RSOs' desires to preserve this image do not relate solely to a professional and emotional loyalty to their former institution and the constitutional oath they took as officers, but they also recognize that protecting their apolitical image helps to sustain their own social stature.

RSOs' images of transcendent politics manifest potential negative elements as well. "Rising above politics" can represent leadership virtue but it can alternatively connote an insidious subversion of democratic politics. The RSO image embodies national unity, self-sacrifice for the common good, and a degree of moral certitude that seemingly disdains petty political conflict. These characteristics often mask decidedly undemocratic undertones. The transcendent image sells well in a polarized political environment and non-military political actors can exploit its value. For example, RSOs now regularly appear at political conventions as "non-partisan" supporters of candidates and attempt to portray a modest "reporting for duty" posture. ${ }^{112}$ From a Machiavellian perspective, a RSO's image of transcendent politics may represent their most valuable political asset but it presents potential dangers to democratic governance.

The preceding categories and the traits within them explain why RSOs deserve special consideration as political actors. Positive and negative manifestations of these traits are possible and influence normative assessments about RSOs' suitability for

${ }^{112}$ Golby, Dropp, and Feaver, Military Campaigns: Veterans' Endorsements and Presidential Elections. 
executive branch service. The next step therefore is to determine which dimensions of these traits prevail in the RSOs that have served in presidential administrations. The categories outlined next begin to provide a framework for making such an assessment.

\section{Categorizing the RSO-Executive Branch Relationship}

Military colonization implies that harmful effects result at the confluence of two conditions: 1) a large number of RSOs in civilian executive branch positions, and 2) an ideological divergence between military officers and civilian officials that results in harmful civil-military relations. If neither of these conditions holds, then other categories are needed to describe the relationship between RSOs and the executive branch. The two-dimensional framework below gives the full range of options for this relationship. 


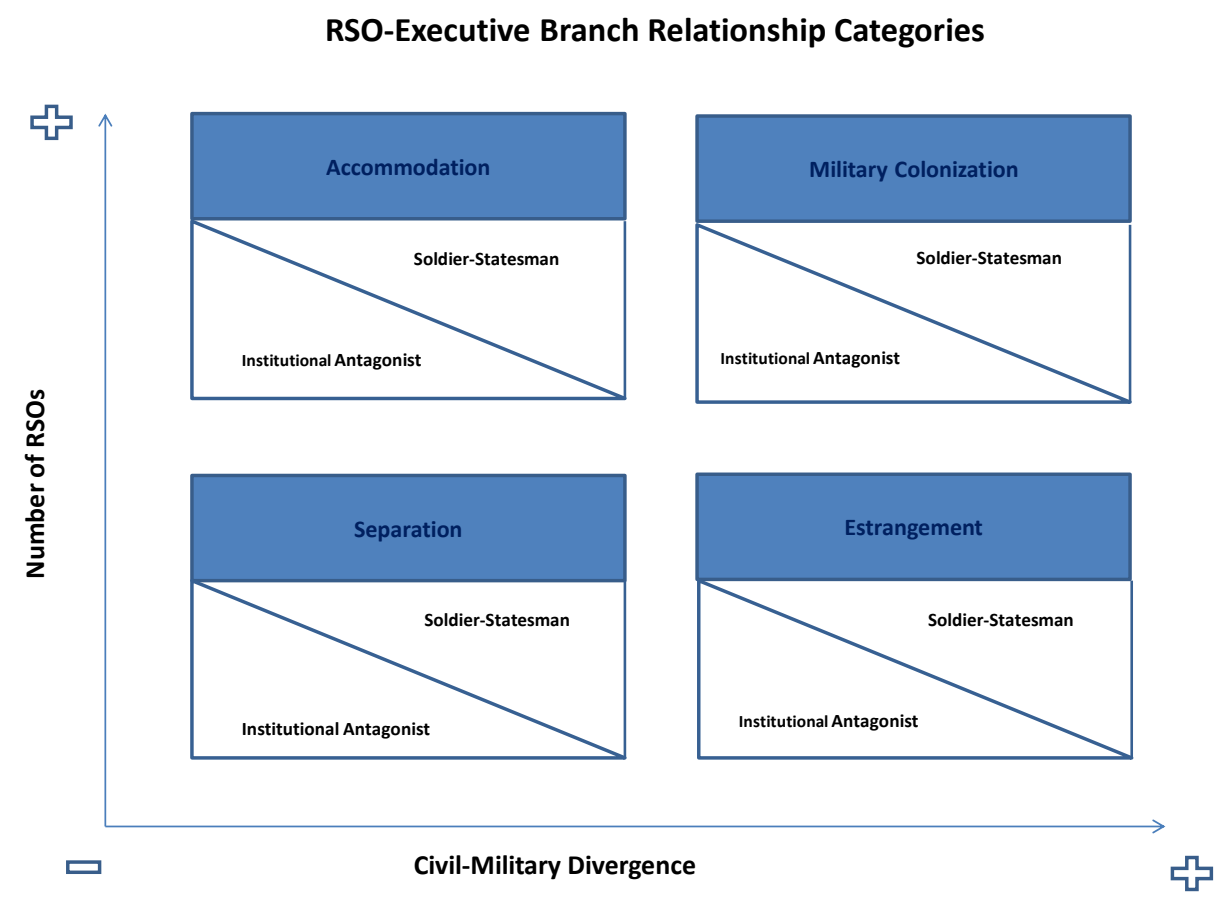

Figure 2-1: Categories of the RSO-Executive Branch Relationship

The vertical axis represents the number of RSOs in the executive branch, while the horizontal axis signifies the divergence between civilian (non-RSO) officials and active military leaders. Situating civil-military divergence is admittedly a subjective enterprise that reflects not only disagreement over policies between civilian and military leaders, but also the underlying ideological and cultural tensions between them. Different modes of capturing the degree of tension will be outlined in Chapter 4 when the dynamics of this variable are more fully discussed.

There are four categories in the framework but only one of them meets the minimum necessary conditions for what scholars call military colonization. Even then, 
as the following chapters will argue, these necessary conditions are not sufficient to cause the harmful effects implied by colonization purveyors.

Each category contains two subcategories that depict alternative orientations that a RSO may exhibit in an administration: Soldier-Statesmen or Institutional Antagonist. Soldier-statesmen RSOs demonstrate the positive dimensions associated with their unique group traits and impede military colonization by acting as credible countervailing forces, trusted agents, technical experts, and models of civic-republican virtue in an administration. Alternatively, institutional antagonist RSOs may potentially serve as burrowed advocates for active military leaders, prestigious proxies for other political actors, corporate agents, or their actions may exhibit disdain toward the democratic "messiness" in executive branch politics. In the institutional antagonist case, both the necessary and sufficient requirements of military colonization exist. For instance, the military colonization category resides at the intersection of increased RSO participation and wide civilian-military divergence. The realization of the negative implications of military colonization requires that, in addition to these two necessary conditions, RSOs must also exhibit institutional antagonist features. The upcoming chapters argue, however, that the soldier-statesman characteristics of RSOs are empirically predominant and not those associated with the deleterious behaviors of an institutional antagonist. Outlined below is a fuller description of the alternative categories and sub-categories: 


\section{General Categories}

Military Colonization: This category refers to periods where the purported necessary conditions exist for the harmful manifestations expected by military colonization claims. These periods are characterized by a strong RSO presence and a wide ideological and cultural divergence and elevated levels of civilmilitary tensions.

Estrangement: This category refers to periods of low RSO presence in executive branch politics and a wide ideological or cultural divergence between active military and civilian executive branch leaders and elevated civil-military tensions.

Separation: This category refers to periods with a low-level of RSO participation in the executive branch and a general ideological consensus and cultural comity between active military and civilian leaders. Low civil-military tensions exist in this category.

Accommodation: This category refers to periods with strong RSO participation in the executive branch and a general ideological consensus and cultural comity between active military leaders and senior civilian. Low civilmilitary tensions exist in this category.

\section{Sub-Category Alternatives}

Institutional Antagonist: This category refers to RSO behavioral patterns that predominantly demonstrate the negative aspects of the unique traits presented earlier. This sub-category depicts RSOs as burrowed advocates who use their executive branch positions to promote the narrow interests of the military and its active leaders. Their actions exude a disdain for the inefficiencies and perceived ethical shortcomings of the democratic process. Behavioral characteristics labeled prestigious proxy and corporate agent are also included in the sub-category although these factors pertain primarily to RSO behavior outside the executive branch. As will be evidenced in Chapter 5, however, the outside-inside distinction in RSO-executive branch relations becomes rather 
murky. The prestigious proxy label refers to behavior where an RSO intentionally uses the prestige of his/her former military rank to influence the electoral success of civilian actors. In cases where RSOs behave as corporate agents, they use their knowledge and expertise of military matters to gain access to civilian and military decision makers in order to promote narrow corporate interests.

Soldier-Statesman: This sub-category reflects the positive manifestations of the unique RSO traits, traits which potentially impede the potential dangers of military colonization. While the necessary conditions of military colonization may exist, the soldier-statesman serves as a bulwark against the realization of its negative implications. If RSOs behave in a manner consistent with this subcategory, they act, for example, as countervailing forces to undue military influence in policy and budgetary decisions, trusted envoys that ensure the mutual concerns of both civilian and military leaders are fairly articulated and understood, and they stand as models of civic-republican service to the nation. Moreover, this sub-category recognizes that the unique technical and leadership skills RSOs gain in the military can be used effectively and independently to promote civilian governmental agencies. The image of General George Marshall stands as the exemplar of the behaviors encapsulated in this sub-category.

A neat categorization that encompasses all dimensions of the RSO-executive branch relationship is unrealistic. Moreover, the degree to which an administration exemplifies a particular category is not static, and the behavior of RSOs obviously reflects an admixture of both positive and negative dimensions associated with their unique traits. International pressures, budgetary constraints, and basic personality conflicts also influence the degree of civil-military tensions that prevail in each category. In any case, the framework above offers a starting point to consider some critical dynamics in the RSO-executive branch relationship. 
Before considering which alternative sub-categories best describe RSO behavior, it is first necessary to situate recent executive administrations within a general category. The next chapter begins this task by turning the focus toward establishing some empirical fidelity on the vertical axis of the framework and examines how many RSOs have served in the executive branch, where they served, and if any longitudinal trends are evident. 


\section{Chapter 3 \\ RSOs \& the American Executive Branch: An Empirical Account}

At first glance the characteristic "mode" of military intervention is the violent overturn of a government and the characteristic "level" is the establishment of overt military rule. Yet often, the military works on governments from behind the scenes; and even when they do establish a military dictatorship, they usually fabricate some quasi-civilian façade of government behind which they retire as fast as possible. Overt military rule is relatively rare, and, apparently, short-lived.

S.E. Finer "The Man on Horseback: the Role of the Military in Politics" (1962) ${ }^{113}$

Studies on the relationship between former military generals and the executive branch not surprisingly tend to focus on the presidency. Ten former military generals served as president, and for a period following the Civil War, being a general seemed a prerequisite. However, the individuals who translated their heroic military reputations into successful presidential bids obviously represent a miniscule subset of the thousands of former military officers who served the United States over the last 230 plus years. The vast majority of these officers, in MacArthur's words, simply "faded away" into American civil society. ${ }^{114}$ Focusing solely on the presidency when studying the relationship between retired senior military officers (RSOs) and executive branch

\footnotetext{
${ }^{113}$ Finer, The Man on Horseback; the Role of the Military in Politics., n. 24 at 4.

${ }^{114}$ Douglas MacArthur, Farewell Address to the US Congress, 19 Apr 1951
} 
politics, however, risks overlooking the broader role they have played in executive branch leadership.

A narrow focus on the presidency also potentially obscures important avenues to approach civil-military relations theory. The image of a tyrannical military figure usurping civil government via the presidency easily excites the public imagination; however, other potential perils receive much less consideration. ${ }^{115}$ For instance, if large numbers of former military officers become embedded in executive government, the policy and planning process may begin to narrowly reflect military outlooks and worldviews and jeopardize liberal notions of civilian control of the military. ${ }^{116}$ An opposite but equally objectionable scenario is an executive branch devoid of any military experience, expertise, or general understanding of the military among its civilian leaders. ${ }^{117}$ This last scenario appears a realistic possibility given the near exhaustion of the World War II generation and increasingly the Vietnam conscript veterans. These demographic trends, coupled with the declining size and intergenerational character of the All-Volunteer Force (AVF) make it a statistical certainty that fewer officials will have

\footnotetext{
${ }^{115}$ Charles J. Jr. Dunlap, “The Origins of the American Military Coup of 2012," Parameters (Winter 1993 1992): 2-20.

${ }^{116}$ Christopher Gelpi and Peter D. Feaver, "Speak Softly and Carry a Big Stick? Veterans in the Political Elite and the American Use of Force," American Political Science Review 96, no. 4 (December 2002): 779793. This research suggests that those senior executive officials with military experience are less likely to promote military options but more likely to promote a higher force levels and more decisive use of force once decision is made to use military options.

${ }^{117}$ Charles J. Jr Dunlap, "Welcome to the Junta: The Erosion of Civilian Control of the U.S. Military," Wake Forest Law Review 29 (1994): 366. Dunlap argued that beginning with the Clinton administration a new Meritocratic class entered government leadership; however, while both the military and the new governing "class" share a meritocratic outlook, the characteristics of the meritocracies differ substantially. According to Dunlap, the civilian Meritocratic Class tends to overemphasize IQ and academic credentials whereas the military meritocracy places primary importance on experience and implementation. Either outlook dominating hinders effective civilian military relations.
} 
military experience in the foreseeable future. Such an absence could deprive the executive branch of unique policy expertise, moral perspectives, and an understanding of the risks and realistic capabilities of military power. Administrations bereft of military experience may lack the expertise required to "check" the policy preferences and recommendations promulgated by active military leaders. In short, understanding both the normative and empirical relationship between RSOs and the executive branch politics requires that research expand beyond the chief executive and into the thousands of positions that comprise modern presidential administrations.

To understand the empirical relationship between RSOs and the executive branch some basic questions need to be answered: 1) how many RSOs have served in senior levels of the executive branch and in which positions, 2) are there identifiable trends in RSO participation levels, and 3) which RSOs serve and what characteristics do they share? Once these questions are addressed, the reasons why RSOs may or may not serve in this way can be explored. What incentives and disincentives, or cultural, legal, and organizational barriers exist that may influence RSO participation levels?

This chapter addresses these questions by focusing on RSO participation in the post-Cold War presidential administrations. The effort requires a quick overview of the executive branch structure which builds the context for understanding the breadth and depth of RSO participation. Empirical data then shows the number and location of those RSOs who reached the upper levels of the executive branch. Of particular interest are 
the trends revealed in the data which presage both dangers and opportunities in the RSO-executive branch relationship.

\section{Part I: RSOs in the Executive Branch 1989-2012}

\section{The Modern American Executive Branch and RSOs}

After every presidential election since 1952, the United States Congress has published a document entitled the United States Government Policy and Supporting Positions, more commonly known as the "Plum Book." ${ }^{118}$ For federal office-seekers, awaiting the publication of the Plum Book loosely compares to college basketball fans waiting for the unveiling of the NCAA tournament brackets, or in the case of college presidents, the anxiety filled days that likely precede the release of the top "Party School" rankings. The Plum Book contains the listings of nearly 8,000 civilian leadership and support positions in the federal government, the vast majority of which reside within the executive branch. The positions listed in the Plum Book attract special interest because they are "exempted" from the traditional civil service system and the system's competitive hiring process. ${ }^{119}$ The Plum Book shows publically recognizable positions such as the Secretary of State and the Secretary of Defense as well as the

\footnotetext{
${ }^{118}$ The House Committee on Oversight and Government Reform and the Senate Committee on Homeland Security and Governmental Affairs alternate responsibility for publishing the document.

${ }^{119}$ Foreword of the 2008 United States Government Policy and Supporting Positions. The number of legislative positions listed in the Plum Book are comparatively few, the majority related to Library of Congress and the US Tax Court appointments. The vast majority represent executive branch positions and thus when referring to the document throughout the paper, I will only be focused on the executive branch positions.
} 
more obscure positions on regulatory and advisory boards, commissions, and independent government corporations. Images of Jacksonian Era officer-seekers stampeding to cash-in on the partisan spoils of electoral success quickly come to mind when paging through the book. Although the published form of the document reflects its mid-twentieth century creation, the underlying purpose of the Plum Book is as old as the Republic.

At first glance, the Plum Book highlights the executive branch personnel system's most distinctive and striking features: its enormous size and its decentralized structure. In practice, no single consolidated federal personnel system exists. The system more accurately resembles a conglomeration of relatively autonomous pay schedules and hiring systems that vary significantly within and across agencies and departments. Frequent changes to position titles, administrative "ranks" of positions, and the organizational hierarchies mark the entire system. Despite the protean characteristics of the system however, the most senior exempted positions show relative continuity both in name and organizational structure. These exempted positions fall into five main categories: 1) Executive Schedule (ES), 2) Senior Executive Service (SES), 3) Senior Foreign Service (FA), 4) "Schedule C" and, 5) a diverse category that contains positions normally classified as competitive civil-service positions but temporarily exempted from 
civil service rules because an administration assigned confidential or policy-determining responsibilities to the office holders. ${ }^{120}$

The competitive versus non-competitive distinction of executive branch positions exposes an inherent tension in the American constitutional design. The tension results from competing desires for a unitary executive branch, loyal and responsive to its executive head, and Congress's constitutional prerogative to ensure legislative oversight of executive personnel and policies. ${ }^{121}$ Congress not only authorizes the number, type, and pay scale of positions in the Plum Book, a responsibility shared by both chambers, but it also determines which of these positions require Senate confirmation. The confirmation process gives Congress the means to judge the competence of presidential nominees, and, importantly for this study, the process also helps the legislative branch ensure civilian control of the military. The Senate not only confirms senior active military leaders into the highest ranks and positions within the military, but the chamber also provides an oversight mechanism to monitor the overall military flavor of executive administrations.

Roughly 1,100 of the nearly 8,000 current executive branch positions require Senate confirmation. Presidentially appointed and Senate confirmed or "PAS" positions represent most of the highest levels of executive leadership in an administration. PAS

\footnotetext{
${ }^{120}$ Senate Committee on Homeland Security and Governmental Affairs, 110th Congress, $2 \mathrm{~d}$ Session, "Policy and Supporting Positions" (U.S. Government Printing Office, Washington, D.C., November 12, 2008).

${ }^{121}$ Steven G. Calabresi and Christopher S. Yoo, The Unitary Executive: Presidential Power from Washington to Bush (New Haven: Yale University Press, 2008); Terry M. Moe, "The Politicized Presidency," in The New Direction in American Politics, ed. John E. Chubb and Paul E. Peterson (Washington, D.C.: Brookings Institution, c1985.), 269-271.
} 
positions include, for example, cabinet secretaries, deputy secretaries, undersecretaries, assistant secretaries, general counsels, etc. ${ }^{122}$ Statutes designate many lesser known and less central policy-making positions as PAS positions also. For instance, the National Council on Disability includes 15 PAS appointments, and the National Foundation on the Arts and Humanities has 29 such positions. ${ }^{123}$ PAS designation signifies that Congress wants to maintain close scrutiny on the appointments to these positions for substantive or political reasons or both.

In addition to the PAS positions, the president also controls over 300 Presidential Appointments or "PA" positions. These influential positions reside predominantly in the White House and the Executive Office of the President and they represent the president's closest and most trusted advisors and aides. The PA positions range from high-visibility positions such as the president's Chief of Staff, Press Secretary, and his Assistant for National Security Affairs (National Security Advisor), to the President's and First Lady's personal aides. Two interrelated features of PA positions make them significant to military colonization claims: 1 ) their weighty influence due to their proximity to the president, and 2) they do not require Senate confirmation. Whereas Congress mandates that PAS officials testify before them upon request, incumbents in PA positions have traditionally been exempted. This feature of PA appointments enables the president to maintain a group of highly trusted and private confidants that resist legislative oversight. These positions therefore complicate institutional checks and

\footnotetext{
${ }^{122}$ See video of Aspen Institute Forum entitled: Commission to Reform the Federal Appointments Process http://www.crfap.org/addressing-the-problems-of-the-appointments-process

${ }^{123}$ Based on 2008 Plum Book Totals
} 
balances and potentially impede congressional efforts to carry out its oversight functions, among them, the responsibility to ensure the military does not gain undue policy input that may detract from true civilian control of the military.

The president also controls nearly 2,000 other "Schedule A, B, and C" appointments that are also excepted from traditional civil service requirements. Schedule $\mathrm{C}$ positions are those designated for individuals involved in making or approving substantive policy recommendations, and that have, "a thorough knowledge of and sympathy with the goals, priorities, and preferences of an official who has a confidential or policy determining relationship with the President or the agency head." ${ }^{124}$ Other Schedule C positions may include the personal secretaries of ES officials or even personal drivers. Administrations normally reserve the remaining A \& B schedule positions for appointees that have unique qualifications or duties, for example, lawyers with highly-particularized legal expertise. ${ }^{125}$ This last group of appointees may often participate in important policy decision-making processes, but their pay schedules and their relative position in the administrative hierarchy more closely resemble positions in the General Schedule (GS) merit system despite their appointee status.

A final type of presidential appointee that requires a brief discussion is the Senior Executive Service (SES) official. SES positions by design exist in the nebulous space between traditional high-level political appointees and senior bureaucratic

\footnotetext{
${ }^{124}$ Senate Committee on Homeland Security and Governmental Affairs, 110th Congress, 2d Session, "Policy and Supporting Positions." Appendix 1

${ }^{125}$ David E. Lewis, The Politics of Presidential Appointments: Political Control and Bureaucratic Performance (Princeton, N.J.: Princeton University Press, 2008), 23.
} 
workers in the merit based civil service system. Established by Title IV of the Civil Service Reform Act (CSRA) of 1978, Congress designed the SES to "ensure that the executive management of the Government of the United States is responsible to the needs, policies, and goals of the nation and otherwise is of the highest quality." ${ }^{126}$ The SES represents an effort to develop, consolidate and maintain a cadre of highly competent and experienced administrative and organizational managers and supervisors to serve as a bridge between political appointees who temporarily lead the agencies, and the permanent civil service workers within the agencies. ${ }^{127}$ Ideally, SES members possess leadership skills that are portable across diverse agencies. System designers envisaged that SES officials would regularly transfer between disparate government agencies over their careers, and as a result, SES officials would develop a strategic understanding of the federal government and inter-departmental issues. ${ }^{128}$

The SES system only permits the president to fill some SES positions with political appointees. Approximately one-half of all SES positions in the executive branch are designated as Career Reserved positions and the other half as General positions. Statutory guidance dictates that Career Reserve positions exist, "to ensure impartiality, or the public's confidence of impartiality of government." ${ }^{129}$ Career SES officials must meet qualifications established by a non-partisan Qualifications Review Board before

\footnotetext{
${ }^{126}$ U.S Office of Personnel Management, History of SES, accessed September 26, 2012, http://www.opm.gov/ses/about_ses/history.asp.

${ }^{127}$ See Maeve P. Carey, The Senior Executive Service: Options for Reform CRS Report for Congress (Congressional Research Service, April 28, 2011).

${ }^{128}$ A recent report on the SES suggests that the mobility goals of the SES program have only marginally been achieved. See report at, Partnership for Public Service, Mission-Driven Mobility: Strengthening Our Government Through a Mobile Leadership Corps, February 29, 2012, http://ourpublicservice.org/OPS/publications/viewcontentdetails.php?id=172.

${ }^{129}$ U.S Office of Personnel Management, History of SES.
} 
becoming permanent SES officials. For Career members, the SES label does not simply denote a certain position, but it is a designation that travels with the individual throughout the federal executive branch. These Career individuals are involuntarily removed from the SES only for cause or poor performance regardless of partisan changes in political administrations.

Career members can fill both Career Reserved designated positions and also another category of SES positions labeled General positions. However, the president also has the flexibility to make non-career, limited term or limited emergency appointments to these General positions. This means presidents can place political appointees into General positions even if the individuals are not part of the SES. Like PA positions, political appointees to General positions in the SES do not require Senate confirmation as long as they meet minimal published competencies. Nonetheless, Congress does not typically challenge the "competencies" of these non-career appointees. ${ }^{130}$ Discussions with some current and former SES members reinforced that SES non-career appointments are best understood as outright political appointments. ${ }^{131}$ Statutes restrict the number of General positions that political appointees can fill, both in the administration as a whole, and within specific departments and agencies. Current statutes mandate that non-career (political) appointees can hold a maximum of $10 \%$ of

\footnotetext{
${ }^{130}$ This assertion is based on a phone interview with a senior personnel official in the Civilian Senior Executive Management Division- Defense Civilian Personnel Advisory Service. The official has responsibilities that include managing the non-career SES appointment process for DOD.

${ }^{131}$ Information provided by two retired Air Force major generals; one who remains in his career SES position in a non-DOD agency and another who retired from a DOD career SES position.
} 
the total number of executive branch SES positions, and only $25 \%$ of a particular agency's SES allocations. ${ }^{132}$

The table below provides a reference for putting the total number and types of positions in perspective. Table 3.1 summarizes the sizes of the different categories over the last two decades. ${ }^{133}$ These figures show the Plum Book data published after the last six presidential elections and the administrations of the post-Cold War presidents (19892012).

Table 3-1: Summary of Positions Subject to Noncompetitive Appointment

\begin{tabular}{|c|c|c|c|c|c|c|c|c|}
\hline & PAS & PA & GEN & NA & TA & SC & XS & Total \\
\hline 1992 & 1163 & 561 & 4305 & 723 & 62 & 1794 & 459 & 9067 \\
\hline 1996 & 1119 & 250 & 3184 & 701 & 125 & 1465 & 459 & 7303 \\
\hline 2000 & 1203 & 223 & 2802 & 648 & 169 & 1287 & 390 & 6722 \\
\hline 2004 & 1137 & 320 & 4555 & 701 & 118 & 1596 & 624 & 9051 \\
\hline 2008 & 1141 & 314 & 3723 & 665 & 121 & 1559 & 473 & 7996 \\
\hline 2012 & 1217 & 364 & 3821 & 680 & 109 & 1392 & 462 & 8045 \\
\hline \multicolumn{9}{|c|}{ PAS= Positions Subject to Presidential Appointment with Senate Confirmation } \\
\hline & \multicolumn{8}{|c|}{ PA = Positions Subject to Presidential Appointment w/o Senate Confirmation } \\
\hline & \multicolumn{8}{|c|}{ GEN = SES General Positions Filled by Career Appointee } \\
\hline & \multicolumn{8}{|c|}{ NA = SES Positions Filled by non-career appointee } \\
\hline & \multicolumn{8}{|c|}{ TA = SES General Position Filled by Limited or Emergency Appointment } \\
\hline & \multicolumn{8}{|c|}{ SC = Positions Filled by Schedule C Excepted Appointment } \\
\hline & \multicolumn{8}{|c|}{ XS = Positions Subject to Statutory Excepted Appointment } \\
\hline
\end{tabular}

\footnotetext{
${ }^{132} 5$ U.S.C 3133-3134

${ }^{133}$ Policy and Supporting Positions Document: 1992, 1996, 2000,2004,2008, 2012 appendices. http://www.gpo.gov/fdsys/pkg/GPO-PLUMBOOK-2012/pdf/GPO-PLUMBOOK-2012.pdf
} 
Table 3.2 and Figure 3.1 below reintroduce RSOs to the discussion and put into context the relative size of the RSO population and the total number of executive branch appointments. Table 3.2 shows the number of General or Flag Officer (G/FO) retirements per fiscal year, and Figure 1 displays the total number of living RSOs. The number of RSOs reflects Department of Defense financial data that lists the total number of RSOs receiving retirement benefits in each fiscal year since $2001 .^{134}$

Table 3-2: G/FO Retirements FY01-FY11

\begin{tabular}{|c|c|c|c|c|c|c|c|c|c|}
\hline & \multicolumn{2}{|c|}{ 4-star } & \multicolumn{2}{c|}{ 3-star } & \multicolumn{2}{c|}{ 2-star } & \multicolumn{2}{|c|}{ 1-star } & Total \\
\hline & Active & Reserve & Active & Reserve & Active & Reserve & Active & Reserve & \\
\hline FY01 & 7 & 0 & 32 & 0 & 34 & 31 & 40 & 62 & 206 \\
\hline FY02 & 8 & 0 & 21 & 1 & 45 & 42 & 40 & 61 & 218 \\
\hline FY03 & 8 & 0 & 27 & 0 & 51 & 32 & 33 & 58 & 209 \\
\hline FY04 & 7 & 0 & 31 & 1 & 52 & 41 & 47 & 63 & 242 \\
\hline FY05 & 11 & 0 & 24 & 0 & 43 & 24 & 44 & 58 & 204 \\
\hline FY06 & 8 & 0 & 24 & 2 & 53 & 40 & 49 & 69 & 245 \\
\hline FY07 & 4 & 0 & 34 & 1 & 39 & 57 & 48 & 70 & 253 \\
\hline FY08 & 14 & 0 & 28 & 0 & 62 & 50 & 39 & 56 & 249 \\
\hline FY09 & 6 & 0 & 23 & 0 & 46 & 33 & 52 & 54 & 214 \\
\hline FY10 & 6 & 0 & 31 & 1 & 55 & 30 & 34 & 55 & 212 \\
\hline FY11 & 10 & 0 & 33 & 0 & 47 & 42 & 47 & 41 & 220 \\
\hline Total & 89 & 0 & 308 & 6 & 527 & 422 & 473 & 647 & 2472 \\
\hline
\end{tabular}
134 Office of the Actuary, Department of Defense, http://actuary.defense.gov/ accessed 21 December
2012 


\section{Figure 3-1: Total Number of RSOs (Including Reserves)}

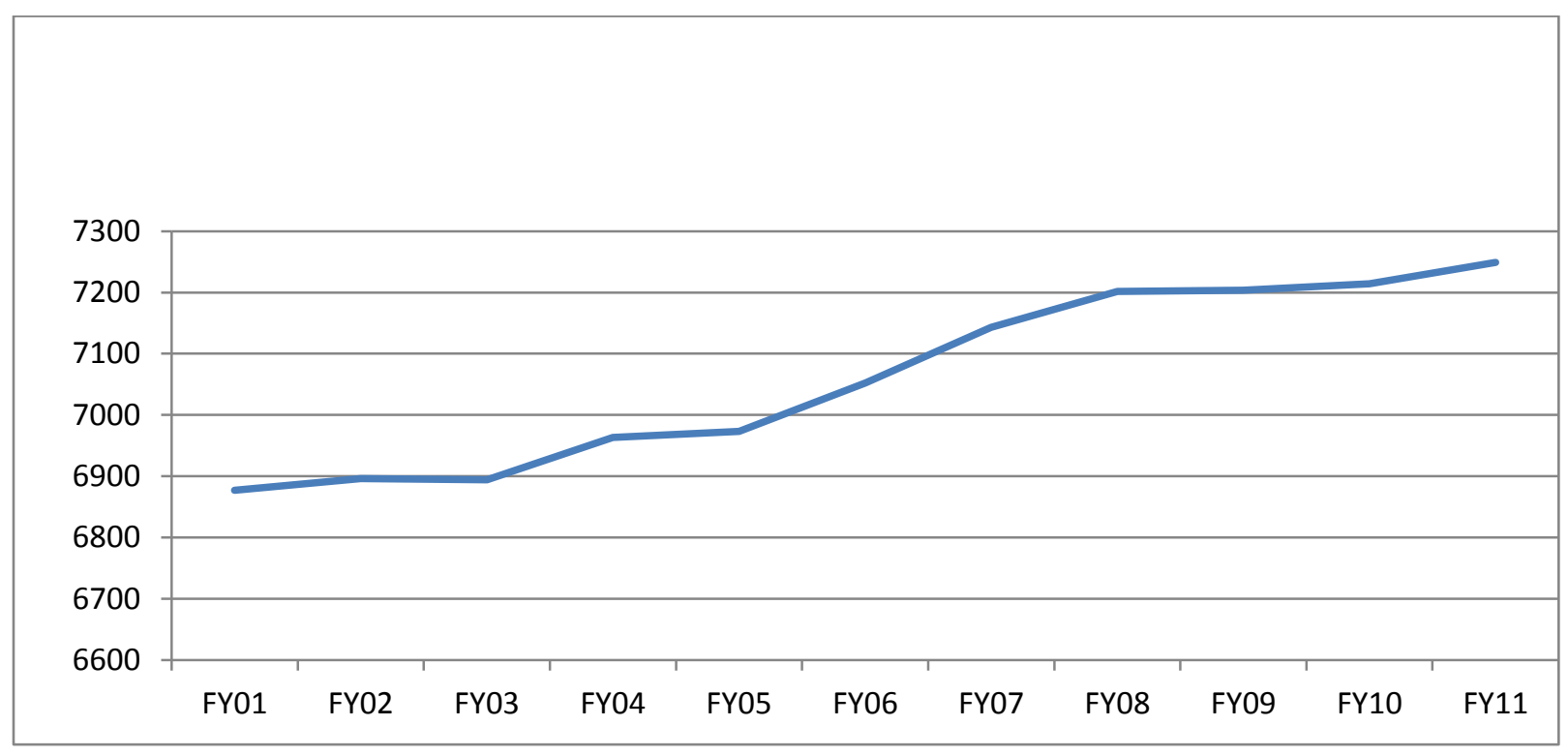

$(\text { See Note) })^{135}$

\footnotetext{
${ }^{135}$ The post-9/11 military resembles what is often referred to as "brass creep." According to testimony provided by the Project on Government Oversight (POGO), the Iraq and Afghanistan conflicts represent the first US armed conflicts in which the number of G/FOs increased at a rate higher than enlisted or lower officer ranks. This "brass creep" was most significantly noted in the 3 and 4-star ranks. According to the POGO report, between 2001 and April 2011, the military added 93 general officers \& 47,602 lower ranking personnel; this equates to adding one general officer for every 512 lower ranking personnel. The report notes that the increase is counterintuitive when considering the national security posture since September 11, 2001. For example, during peacetime the ratio of officers to enlisted personnel, and specifically the ratio of senior officers within the officer corps, would be expected to be larger. The larger percentage is justified by the amount of time \& training required to sufficiently build \& maintain the officer corps. Officers also maintain the framework for expansion of the lower ranks if national security threats dictate. However, as the POGO report explains, the "creep" within the general officer ranks since $9 / 11$ occurs during a time of continuous military operations where more junior military members are ostensibly required. The number of $3 \& 4$-star G/FOs increased by $24 \%$ between the end of the Cold War (1991) \& April 2011 while the overall size of the officer and enlisted ranks decreased by $19 \%$ \& 30\% respectively (page 20). The Air Force \& Navy showed the most "creep," each adding more G/FO positions than the Army \& Marines combined; this occurred at the same time that the Air Force \& Navy together had cut over 70,000 lower ranking personnel \& fewer personnel active in contingency operations. The testimony by POGO's Mr. Freeman illustrated that the Navy now almost has more Admirals than they do ships! See Ben Freeman, "Testimony Before the Senate Armed Services Committee Subcommittee on Personnel on 'General and Flag Officer Requirements'," POGO: Project on Government Oversight, September 14, 2011, http://www.pogo.org/our-work/testimony/2011/ns-wds-20110914.html.
} 


\section{A Framework for Refining the Population of Interest}

Unfortunately, neither a consolidated data set containing the professional backgrounds or veteran status of executive branch incumbents, nor a register of the post-retirement professions of RSOs were found. ${ }^{136}$ The post-Cold War presidents averaged over 8,000 non-competitive appointments and collecting biographical data on all of them presented a daunting, cumbersome, and ultimately unnecessary task for the purposes of this study. Limiting the examination to the post-Cold War administrations, focusing only on the most consequential policy making positions, and adding some reasonable assumptions winnowed the population into a smaller yet manageable size. The winnowing tools each require a brief explanation.

\section{Periodization}

The analysis of RSO participation focuses primarily on the period from January 1989, George H.W. Bush's inauguration, through Obama's first term. With respect to civil-military relations, the administrations in this time period share some important distinctions from their Cold War predecessors. These differences can be placed into three categories: 1) strategic environment, 2) military reputation, and 3) military

\footnotetext{
${ }^{136} \mathrm{~A}$ recent article in the Huffington Post claims that over $70 \%$ of retiring G/FOs are hired by defense contractors. However, the article does not address the remaining 30\%. See Luke Johnson, "Report: 70 Percent of Retired Generals Took Jobs With Defense Contractors or Consultants," The Huffington Post, November 19, 2012, http://www.huffingtonpost.com/2012/11/19/defense-contractorsgenerals_n_2160771.html.
} 
leadership structure. The interaction of these three categories makes the RSO-executive branch relationship during this period worthy of unique focus.

First, since the period extends over only the post-Cold War period, the international strategic environment and the national security threats faced by the United States have some consistency. The demise of the Soviet menace and the associated reduction in large-scale conventional and nuclear confrontation risks places these administrations in a strategic environment that differs substantially from earlier post-World War II presidents. This new setting not only transformed the size and activities of the military, but it also altered the competencies required of national security experts. Smart conventional bombs, stealth aircraft, drones and high-tech intelligence collection replaced nuclear war gaming and plans for defending the Fulda Gap.

This periodization divide is not meant to suggest that the 11 September attacks failed to significantly alter the US security environment for post-9/11 administrations. The chosen division more modestly suggests that with respect to national security concerns, post-Cold War presidents share more in common with each other than with the Cold War presidents they followed. The post-Cold War presidents still face the leadership conundrum described by Neustadt, but the military they oversee and the security environment they face differs markedly from their predecessors. ${ }^{137}$ The first Gulf War initiated the transition from a strategic military environment focused on

\footnotetext{
${ }^{137}$ Richard E. Neustadt, Presidential Power and the Modern Presidents : The Politics of Leadership from Roosevelt to Reagan (New York: Free Press, 1990).
} 
superpower standoffs to one focused on smaller scale conflict and with an amorphous yet more uncertain security threat. ${ }^{138}$

The period also reflects consistency in how the public relates to the military and its uniformed leaders. The Reagan administration accelerated a revitalization of the military in terms of its size, capabilities, and also public esteem. In The Nightingale's Song, author Robert Timberg argues that Reagan's revitalization of the military was rooted much deeper than just budget increases, but more significantly, he successfully recast Vietnam as a noble cause and rejuvenated pride within the ranks. ${ }^{139}$ In Timberg's account:

...Reagan regularly portrayed servicemen not as persons to be feared and reviled-ticking time bombs, baby-killers, and the like-but as men to whom the nation should be grateful, worthy of respect and admiration. To the men of the armed forces, he had a single, unvarying them: I appreciate what you have done. The whole nation does. Wear your uniforms with pride. ${ }^{140}$

The revitalization discussed above powerfully manifested itself during the Bush 41 administration and the 1991 Gulf War. ${ }^{141}$ The United States transitioned to an allvolunteer force in 1973 , but it took Desert Storm to reveal the true professional character and renewed morale of the post-Vietnam military. The demise of the Cold War and the end of the first Gulf War led to significant declines in the size of the

\footnotetext{
${ }^{138}$ Ricks, The Generals, chap. 23.

${ }^{139}$ Robert Timberg, The Nightingale's Song (New York: Simon \& Schuster, 1995), 17.

140 lbid.

${ }^{141}$ Works documenting the military buildup and the improved moral of the military during this period are prevalent. For two particularly interesting and different aspects of the subject see, Andrew J. Bacevich, The New American Militarism: How Americans Are Seduced by War (New York: Oxford University Press, 2005); James R. Locher, Victory on the Potomac : the Goldwater-Nichols Act Unifies the Pentagon (College Station: Texas A \& M University Press, 2002).
} 
military, but the public prestige of the military engendered by the conflicts continued unabated. ${ }^{142}$ The American public heaped adulation not only on the individual soldiers, but showered it upon senior military leaders as well. This trend contributes to the development of a public much more comfortable with military leaders assuming more public and visible roles. ${ }^{143}$ Many civil-military scholars suggest that these same factors generated a new conceptual environment for considering civil-military relations, an environment that further binds together the post-Cold War presidencies. ${ }^{144}$

Finally, the organizational leadership structure of the military also remained relatively consistent across the period but vastly different from earlier Cold War days. These organizational changes relate primarily to the active military, but they still are relevant for understanding some dynamics of the RSO-executive branch relationship. The organizational alterations resulted in a widening of public perceptions regarding the leadership and political competencies possessed by senior military officers and by association, RSOs. In particular, legislation passed in 1986 brought the most farreaching structural changes to the institutional military since immediately following World War II. The Goldwater-Nichols National Department of Defense Reorganization Act significantly altered the advisory role of the nation's top military leaders, greatly

\footnotetext{
${ }^{142}$ Gallup, "Confidence In Institutions," 24 September 2012, Gallup Polls on the Confidence in Institutions, 2012, http://www.gallup.com/poll/1597/confidence-institutions.aspx; For a more scholarly treatment on civil-military trust see Paul Gronke and Peter D. Feaver, "Uncertain Confidence: Civilian and Military Attitudes About Civil-Military Relations," in Soldiers and Civilians: The Civil-Military Gap and American National Security, ed. Peter D. Feaver and Richard H. Kohn (Cambridge, Mass: MIT Press, 2001), 129-162. ${ }^{143}$ Bacevich, The New American Militarism, chap. 4; Dunlap, "Welcome to the Junta," 1994, 352-354.

${ }^{144}$ Russell F. Weigley, "The American Civil-Military Cultural Gap: A Historical Perspective, Colonial Times to the Present," in Soldiers and Civilians: The Civil-Military Gap and American National Security, ed. Peter D. Feaver and Richard H. Kohn (Cambridge, Mass: MIT Press, 2001), 215-246.
} 
empowered the Chairman of the Joint Chiefs of Staff (JCS) and the unified "combatant commanders," and, as a consequence, increased their public visibility. ${ }^{145}$

Goldwater-Nichols primarily aimed to address functional deficiencies in military leadership arrangements by alleviating inefficiencies caused by bitter inter-service rivalries. The reforms reduced the independent authority of the individual service chiefs which succeeded in alleviating some harmful effects of inter-service rivalries; however, inter-service rivalry also weakened a key institutional feature for ensuring civilian control. Service jealousies previously led military leaders to selfishly defend their own prerogatives, strategic outlooks, and budgets, and saw this competition as a zero-sum game. Despite the inherent inefficiencies in this struggle, the inter-service conflicts helped mitigate collusion between the armed branches and dispersed the influence of senior military leaders. Under Bush 41, the institutional military completed the transition to the new system and the President appointed the first JCS chairman under the reforms. ${ }^{146}$ The Chairman's enhanced public visibility placed him in a more central political setting and blurred his relationship to policy advocacy. ${ }^{147}$ Goldwater-Nichols also, perhaps inadvertently, altered the institutional dynamics of national security policy making and how military leaders influenced it. ${ }^{148}$ By some accounts, these changes created a favorable environment for the rise of "celebrity" generals who used their

\footnotetext{
${ }^{145}$ Locher, Victory on the Potomac; Gordon Nathaniel Lederman, Reorganizing the Joint Chiefs of Staff : the Goldwater-Nichols Act of 1986 (Westport, Conn.: Greenwood Press, 1999).

${ }^{146}$ Admiral William J. Crowe was the sitting Chairman during the implementation of Goldwater-Nichols and served as a transitional figure to the new system. President Bush appointed Colin Powell in October 1989.

${ }^{147}$ Ackerman, The Decline and Fall of the American Republic, chap. 2.

148 Dunlap, "Welcome to the Junta," 1994, 372.
} 
public stature to influence civilian policy making, and in turn capitalized on their public stature once they retired. ${ }^{149}$

In addition to the Chairman's more public role, Goldwater-Nichols also altered career development patterns of all senior military officers. ${ }^{150}$ The Act made "joint" duty a prerequisite for promotion to the G/FO ranks and as a consequence lured the most promising officers away from career paths confined only to their respective service. Not only did the joint requirement expand the inter-service perspective of rising G/FOs, but it also more fully exposed them to the inter-agency process and a wider range of civilian leaders in the executive branch. Whereas expertise within one's service previously determined G/FO promotions, in the post-Cold War period inter-agency experience became a critical requirement for attaining higher rank. ${ }^{151}$ Scholars Roman and Tarr captured the essence of this change when they concluded that being a "general" now required one to be a much better "generalist." ${ }^{152}$ This consideration becomes important with respect to RSOs because it suggests that their generalist skills can be applied across a wide spectrum of executive leadership positions.

In short, many factors contribute to making the post-Cold War presidential administrations and their relationship to military leaders different from their Cold War

\footnotetext{
${ }^{149}$ Ackerman, The Decline and Fall of the American Republic, chap. 2.

${ }^{150}$ Peter J. Roman and David W. Tarr, "Military Professionalism and Policymaking: Is There a Civil-Military Gap at the Top? If So, Does It Matter?," in Soldiers and Civilians: The Civil-Military Gap and American National Security (Cambridge, Mass: MIT Press, 2001), 403-428.

${ }^{151}$ Thomas Ricks in The Generals provides a counter argument to the notion that current senior officers now have a broader strategic perspective. Ricks claims that the "professionalism" of the senior officer corps over the last two decades has advanced primarily in the "tactical" realm and less so in the strategic. Especially see chapters 23-27.

${ }^{152}$ Roman and Tarr, "Military Professionalism and Policymaking: Is There a Civil-Military Gap at the Top? If So, Does It Matter?," 406.
} 
predecessors. The differences not only impact relationships between the institutional military and the executive branch, but they also influence how RSOs relate to the political system.

\section{Positions of Interest}

This study confines its analysis primarily to PAS and PA appointments, but a brief case study later in the chapter momentarily expands the focus to a set of SES appointments as well. The positions included in the study represent the highest levels of policy making and/or political patronage in the executive branch. As presented earlier in Table 3.1, a combined 2,000 positions in each executive administration fall within these categories. However, a much smaller subset contains those positions that exert some significant influence on matters related to national security policy making. The particular composition of this subset varies across administrations, issues areas, and like all other human organizations, personalities and personal relationships undoubtedly play an important role also; hierarchical organizational charts can only provide an entry point for considering which positions actually wield national security policy making influence. Despite the nuances of organizational structure and personalities, executive branch national security policy making occurs predominantly within certain departments and at certain leadership levels. Tables 3.3 and 3.4 below display the respective organizations included in this analysis, and with some minor exceptions, the 
total number of presidential appointments that were made in each respective Executive Schedule (ES) category since Bush 41's inauguration. ${ }^{153}$

\begin{tabular}{|c|c|c|c|c|c|c|c|c|c|c|c|c|c|}
\hline \multicolumn{14}{|c|}{ Table 3-3: Positions of Interest by Department } \\
\hline \multirow[t]{2}{*}{ Department } & \multicolumn{6}{|c|}{ ES Position Totals By Category } & \multirow[t]{2}{*}{ Department } & \multicolumn{6}{|c|}{ ES Position Totals By Category } \\
\hline & 1 & 2 & 3 & 4 & 5 & Total & & 1 & 2 & 3 & 4 & 5 & Total \\
\hline $\mathrm{CIA}$ & 0 & 8 & 7 & 7 & 0 & 22 & USDA & 8 & 5 & 31 & & & 44 \\
\hline DOE & 7 & 10 & 9 & 61 & 0 & 87 & DOC & 9 & 10 & 39 & & & 58 \\
\hline DOD & 7 & 61 & 47 & 218 & 1 & 334 & EDU & 5 & 9 & 9 & & & 23 \\
\hline DNI & 4 & 8 & 0 & 3 & 0 & 15 & HHS & 5 & 7 & 1 & & & 13 \\
\hline DHS & 4 & 15 & 14 & 12 & 0 & 45 & HUD & 7 & 5 & 1 & & & 13 \\
\hline DOS & 6 & 10 & 45 & 163 & 0 & 224 & DOI & 5 & 5 & 1 & & & 11 \\
\hline DOT & 7 & 28 & 40 & 47 & 4 & 126 & DOL & 5 & 9 & 0 & & & 14 \\
\hline VA & 6 & 5 & 15 & 60 & 0 & 86 & EOP & 23 & 27 & 32 & & & 82 \\
\hline DOJ & 6 & 14 & 32 & 10 & 3 & 65 & WH & 55 & (PA) & & & & 55 \\
\hline \multirow[t]{2}{*}{ TREAS } & 7 & 9 & 35 & 2 & 0 & 53 & $\mathrm{AMB}$ & 1488 & (FS) & & & & 1488 \\
\hline & & & & & & & Total & 1665 & 227 & 361 & 515 & 1 & 2769 \\
\hline
\end{tabular}

\begin{tabular}{|c|c|c|c|c|c|c|c|c|c|}
\hline \multirow[t]{2}{*}{ Department } & \multicolumn{4}{|c|}{ ES Position Totals By Category } & \multirow[t]{2}{*}{ Department } & \multicolumn{4}{|c|}{ ES Position Totals By Category } \\
\hline & 1 & 2 & 3 & Total & & 1 & 2 & 3 & Total \\
\hline DNFSB & 0 & 0 & 26 & 26 & NSF & 0 & 5 & 5 & 10 \\
\hline EPA & 0 & 6 & 9 & 15 & NTSB & 0 & 0 & 0 & 0 \\
\hline FCC & 0 & 0 & 6 & 6 & NWTRB & 0 & 0 & 0 & 0 \\
\hline FEMA & 0 & 3 & 0 & 3 & OGE & 0 & 0 & 4 & 4 \\
\hline FERC & 0 & 0 & 8 & 8 & OPM & 0 & 6 & 6 & 12 \\
\hline FMC & 0 & 0 & 5 & 5 & Peace Corps & 0 & 0 & 0 & 0 \\
\hline GSA & 0 & 0 & 6 & 6 & PRC & 0 & 0 & 0 & 0 \\
\hline NASA & 0 & 5 & 4 & 9 & USAID & 0 & 7 & 5 & 12 \\
\hline \multirow[t]{2}{*}{ NRC } & 0 & 9 & 11 & 20 & & & & & \\
\hline & & & & & Total & 0 & 41 & 95 & 136 \\
\hline
\end{tabular}

See note ${ }^{154}$

${ }^{153} \mathrm{DOJ}$ and Treasury figures for ES levels 4 and 5 do not represent the complete population of positions in these departments. The ones included are those that have at least some minimal relationship to national security issues. 
Tables 3.3 and 3.4 include over 450 PAS and PA individual positions included in the data set for each administration from Bush 41 to Obama. Even this significantly reduced population of positions grossly exaggerates the number of truly key policy makers, a point considered later. Nonetheless, this wider net adds confidence that significant policy makers are captured in the analysis. As annotated in the tables, only Level 1-3 ES positions were analyzed for some department and agencies. For example Department of Agriculture and Department of Health \& Human Services positions below Level 3 were excluded because of their remote relevance to national security issues as indicated by their job titles. Admittedly, many job titles in the included departments and agencies, for instance in Transportation and State, only marginally reflect national security policy responsibilities as well; however, because the overarching mission of these larger departments relates so closely to national security policy making, all of their respective ES positions (1-5) remain part of the analysis. Table 3.5 below provides some examples of what types of positions correspond with each particular ES level.

\footnotetext{
${ }^{154}$ DNFSB-Defense Nuclear Facilities Safety Board; EPA-Environmental Protection Agency; FCC-Federal Communications Commission; FEMA-Federal Emergency Management Agency; FERC-Federal Energy Regulatory Commission; FMC-Federal Maritime Commission; GSA-General Services Administration; NASANational Aeronautics and Space Administration; NSF-National Science Foundation; NRC-Nuclear Regulatory Commission; NTSB-National Transportation and Safety Board; NWTRB-Nuclear Waste Technical Review Board; OGE-Office of Government Ethics; OPM-Office of Personnel Management; PRCPostal Rate Commission; USAID-United States Agency for International Development
} 


\begin{tabular}{|c|c|}
\hline \multicolumn{2}{|c|}{ Table 3-5: Examples of Executive Schedule (ES) Positions } \\
\hline ES Level 1 & $\begin{array}{c}\text { Cabinet Secretaries, Director of DNI, Director of OMB, } \\
\text { etc. }\end{array}$ \\
\hline ES Level II & $\begin{array}{c}\text { Deputy Secretaries, Service Secretaries (Army, Navy, } \\
\text { Air Force), Director of CIA, Director of FBI, etc. }\end{array}$ \\
\hline ES Level III & Under Secretaries and most Board Positions \\
\hline ES Level IV & Assistant Secretaries, General Counsels, Inspector \\
Generals
\end{tabular}

Since the dataset is confined to the roughly 450 PAS and PA appointments in each administration, a brief accounting of which positions get left out is warranted. Based on the Plum Book's list of PAS positions, the top five agencies or departments with the most number of PAS positions but not included in the data set are: 1) Justice Department officials below ES Level 3 (220 PAS appointments), ${ }^{155}$ 2) National Foundation of the Arts and the Humanities (29), 3) United States Tax Court (19), 4) Broadcasting Board of Governors (17), and 5) Corporation for National and Community Service, and the National Science Foundation (18 each). ${ }^{156}$ Other than the Justice Department officials, these appointments show little connection to areas where potential militarization in the executive branch would ostensibly present dangers. The large number of Justice Department officials excluded initially seems problematic. For example, the controversy during the Bush 43 administration over the Torture Memos

\footnotetext{
${ }^{155}$ Despite excluding most ES 4 \& 5 Justice Department appointees for the reasons mentioned, some were included because of their direct relationship to significant law enforcement functions. For example, positions such as the Deputy Administrator of the DEA and the Director of the U.S. Marshall service were included, whereas the large number of US Attorneys were not. See Appendix 1 for included positions.

${ }^{156}$ Based on Summary of Positions Subject to Noncompetitive Appointment in 2008 Plum Book.
} 
demonstrates that these legal officials can exert a significant impact on national security politics. However, attorneys fill nearly all these Justice positions. Some RSOs did serve on active-duty as lawyers and judges so the possibility they may fill one of the Justice positions cannot be discounted. ${ }^{157}$ Nevertheless, excluding this large group of PAS appointments is methodologically palatable for two reasons: lawyers represent only a tiny number of active-duty G/FOs, and military lawyers primarily serve in advisory roles and do not occupy the command positions normally associated with senior military leaders. Active-duty lawyers often enter the military through different commissioning programs than "line" officers and have dissimilar career paths. Military lawyers also remain closely intertwined with the professional norms of the civilian legal profession. These characteristics of military lawyers arguably civilianize them in important respects when compared to other operational officers. Bottom line, excluding the Justice Department lawyers may overlook some RSOs, but not the type normally associated with civil-military relations concerns.

With the help of a couple of assumptions, confining the search for RSOs to the ES Level 1-5 positions also appears more methodologically reasonable. These assumptions relate to comparisons between military rank and equivalent civilian rank in the ES system. A first assumption suggests that equivalent compensation levels across the federal government represent roughly equivalent levels of professional responsibility and policy making influence. Statutory guidelines provide at least a tenuous connection

\footnotetext{
${ }^{157}$ See 10 USC $\S 3037$. In e-mail correspondence (11 January 2013) with a current member of the Army JAG corps, the officer explained that each service had only one three-star position and one two-star position for JAG officers. An additional three-star and two-star serve on the joint staff. He explained that the one-star JAG generals are included in the regular pool of G/FOs.
} 
between the pay scales of senior military officers and those in high-level executive branch positions. During their active service, statutes restrict G/FOs from earning higher pay than ES Level II appointees regardless of their tenure as a senior officer. ${ }^{158}$ This codified restriction suggests that Congress does indeed recognize, or at least desires, some modicum of professional equivalence between the ES positions and senior military positions.

A second related assumption suggests that if RSOs pursue executive branch service, they will do so at a pay level somewhat commensurate or higher than their former active-duty salary. If pay in federal positions reflects a comparative level of professional responsibility, RSOs would not likely pursue positions that compensated them markedly below their previous pay level. Since ES level 1-3 compensation is commensurate with the pay of senior military leaders it follows that the search for RSOs should focus on these positions.

A final assumption submits that RSOs who pursue executive branch employment will do so in policy areas that use the specific skills gained in their military careers. These skills include both leadership competencies as well as technical expertise. As mentioned in the last chapter, the Military Model of leadership places a heavy emphasis on developing a broad range of leadership competencies in its officers. ${ }^{159}$ Military officers, especially senior officers, often change positions as frequently as every year and the position responsibilities and scope can be widely disparate from one assignment to the

\footnotetext{
${ }^{158}$ See 37 USC §203

${ }^{159}$ Robbert, "Developing Leadership: Emulating the Military Model."
} 
next. They develop competencies for leading or commanding that assumedly are portable across organizations. Nonetheless, despite the purported generalized leadership competencies, RSO develop expertise predominantly in areas related to national security, logistics, transportation, weapons procurement, etc. In sum, this third assumption simply suggests that while RSOs have ostensibly developed broad-based leadership competencies, they most likely exercise these competencies in areas that use their technical expertise that relate to national security issues. This limited assumption permits many federal agencies, for instance the Food and Drug Administration or Farm Bureau, to be reasonably excluded from analysis.

Within the parameters discussed above, the original data set constructed for this study includes all individuals who served in the positions of interest beginning with the Bush 41 administration. The complete data set listed in Appendix 3.1 includes over 3,000 appointments to ES level positions and ambassadorships. Biographical information was collected from diverse sources to confirm the military status of the individual appointees. The published testimony of Senate confirmation hearings provided the primary source for the biographical sketches, especially for all Department of Defense and Department of Homeland Security appointees. Where committee hearings did not provide the data, official biographies from departmental websites or official presidential nomination announcements were used. In a limited amount of cases where no official government biographies could be found, credible corporate or academic websites usually contained the relevant information. The biographical data 
obtained from these sources included the confirmation date, the veteran status and service of each individual, and their military rank at retirement.

\section{Empirical Findings}

A sequence of increasingly constrictive filters on the types of executive appointments considered helps frame the empirical findings. ${ }^{160}$ Filter 1 examines the entire data set of executive appointments outlined in Appendix 3.1 and searches for the number of G/FOs. This group contains senior military officers still on active duty, RSOs, and retired US Coast Guard admirals although they technically are not considered part of the armed branches. Ambassador appointments are presented separately. Subsequent filters will remove active G/FOs and Coast Guard admirals from the data, but including them provides the widest framework to initially assess military colonization claims. Figure 3.2 and Figure 3.3 present the results from Filter 1 as well as the distribution across ES levels:

\footnotetext{
${ }^{160}$ Appendix 1 annotates which positions are included in each filter.
} 
Figure 3-2: Total G/FO ES Appointments by President

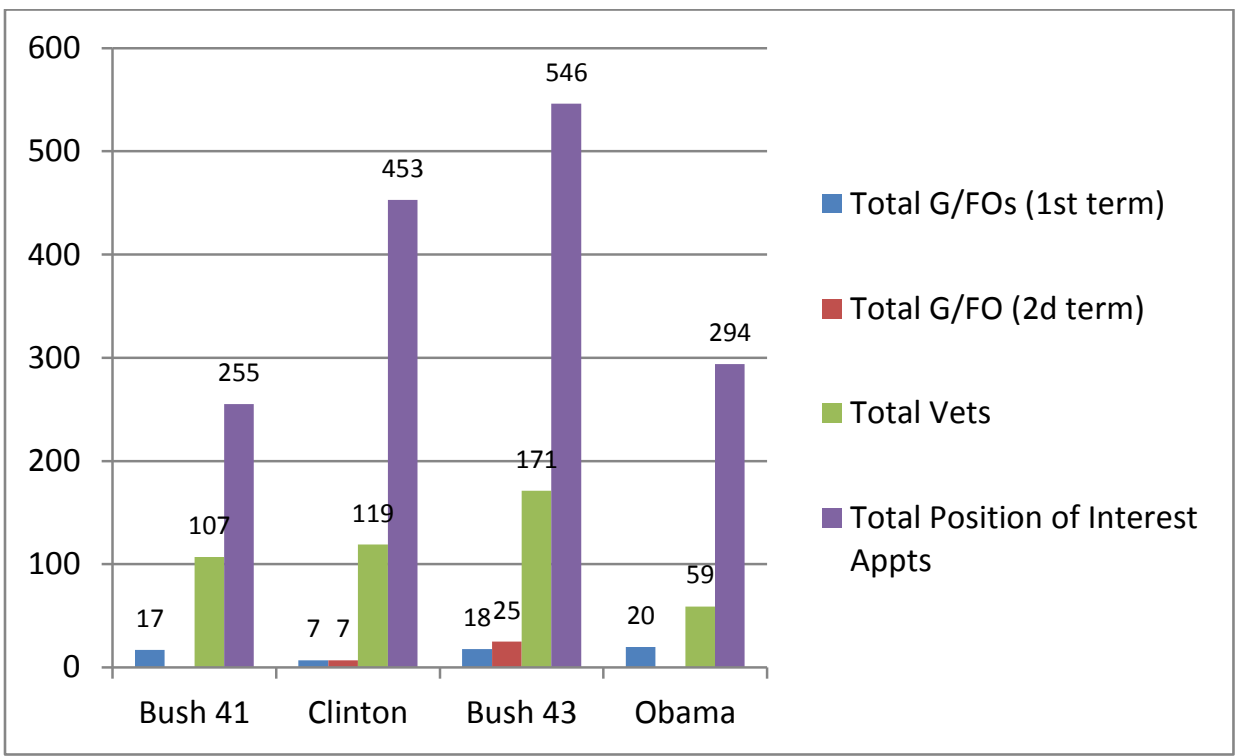

Figure 3-3: G/FO Appointment by ES Level

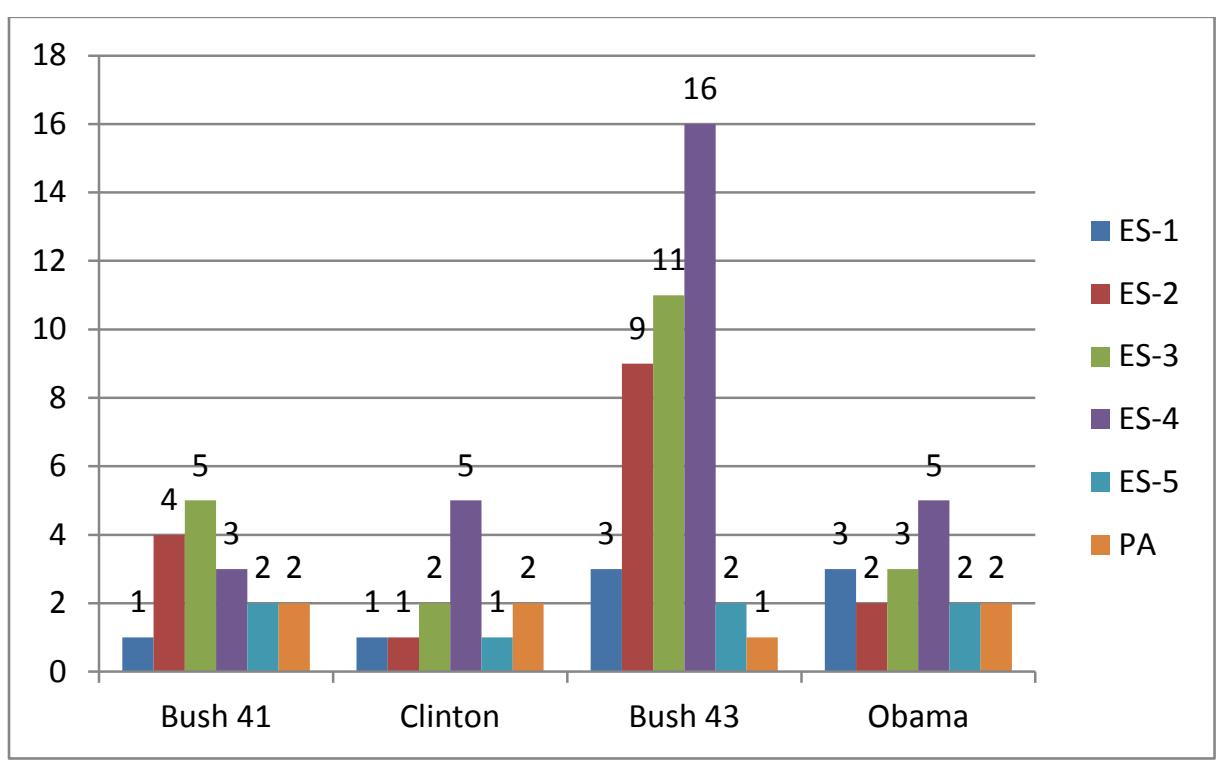


Figure 3-4: RSO Ambassador Appointments

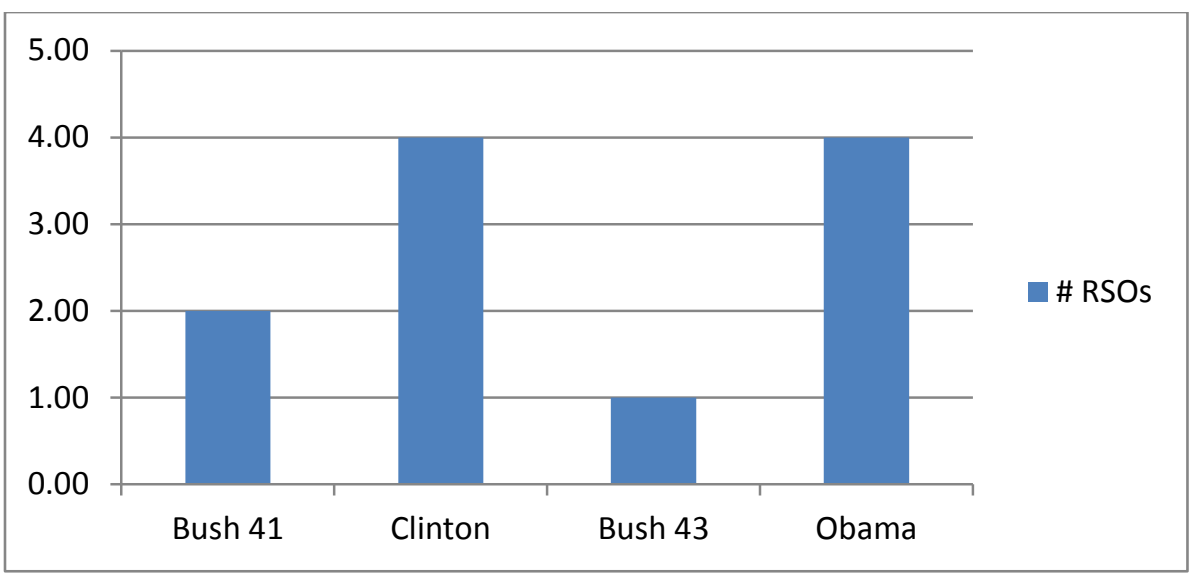

Figures 3.2 and 3.4 display a combined total of 94 RSOs and G/FOs nominated and confirmed to ES and ambassador positions. ${ }^{161}$ Obama's and Bush 43's first administrations and Bush 41's term demonstrate a noteworthy parity in the number of G/FOs appointments, although Obama shows a much smaller veteran presence overall. The Clinton and Bush 43 administrations reveal a noticeable divergence in totals despite both having served two terms. Bush 43 appointed over three times the number of G/FOs as Clinton. In fact, Bush 43's total of 43 (42 ES plus 1 ambassador) equates to $80 \%$ of the combined total of the other three presidents. Although this analysis focuses on RSOs, Figure 3.2 displays the total number of veterans only as a potential, albeit rough indicator of the overall military flavor of the respective administrations.

Table 3.6 below shows the distribution of these G/FO nominations across the executive branch departments and agencies. ${ }^{162}$ The "WH" designation indicates PA appointments within the White House whereas the Executive Office of the President or

\footnotetext{
${ }^{161}$ Appendix 2 contains the complete listing of individuals and positions of executive branch RSOs

162 Gray fill in the table highlights that the respective agencies were not in existence during the corresponding administrations.
} 
"EOP" appointments denote PAS positions outside the White House staff. As shown

below, the G/FO appointments disperse rather broadly across departments and agencies.

Table 3-6: G/FOs By Department \& Agency

\begin{tabular}{|cccccc|}
\hline & Bush 41 & Clinton & Bush 43 & Obama & Total \\
AMB & 2 & 4 & 1 & 4 & 11 \\
CIA & 1 & 1 & 2 & 1 & 5 \\
DHS & 0 & 0 & 3 & 0 & 3 \\
DNI & 0 & 0 & 4 & 2 & 6 \\
DOC & 0 & 0 & 1 & 0 & 1 \\
DOD & 2 & 3 & 10 & 6 & 21 \\
DOE & 2 & 2 & 0 & 0 & 4 \\
DOS & 0 & 0 & 4 & 0 & 4 \\
DOT & 4 & 2 & 5 & 0 & 11 \\
EOP & 0 & 1 & 0 & 1 & 2 \\
FMC & 1 & 0 & 0 & 0 & 1 \\
NASA & 1 & 0 & 0 & 1 & 2 \\
NRC & 0 & 0 & 0 & 0 & 0 \\
NTSB & 0 & 0 & 1 & 0 & 1 \\
Treas & 0 & 0 & 1 & 0 & 1 \\
VA & 2 & 0 & 9 & 3 & 14 \\
WH & 2 & 1 & 2 & 2 & 7 \\
Total & 17 & 14 & 43 & 20 & 94 \\
\hline
\end{tabular}

Perhaps not surprisingly, the Department of Defense (DOD) contains the largest number of G/FO appointments and therefore it deserves some special consideration.

Despite the larger total, none of the DOD appointments were to the senior-most positions, an observation which primarily reflects the influence of legal barriers. ${ }^{163}$ Statutes not only prohibit active military officers from serving as either the Secretary of Defense, Deputy Secretary or Under Secretary of Defense for Policy, but they also

\footnotetext{
${ }^{163}$ President Clinton did however nominate a highly touted RSO to the Secretary of Defense position, Admiral Bobby Ray Inman, following Les Aspin's resignation. Inman later asked to have his nomination removed citing a "modern McCarthyism" against his reputation and ultimately noting, "I did not want this job." See R.W. Apple Jr, "A Nominee's Withdrawal; Inman Withdraws as Clinton Choice for Defense Chief," The New York Times, January 19, 1994, http://www.nytimes.com/1994/01/19/us/a-nominee-swithdrawal-inman-withdraws-as-clinton-choice-for-defense-chief.html?pagewanted=all\&src=pm.
} 
mandate that a minimum period of seven years elapses between regular active military commissioned service and appointment to these three positions. ${ }^{164}$

The National Security Act of 1947, and the 1949 amendments to the Act, created the basic structure of the modern Department of Defense and specifically mandated that individuals appointed to the positions "...come from civilian life." The original Act required a 10 -year lapse between active military service and civilian appointment. ${ }^{165}$ The National Defense Authorization Act of 2008 reduced the waiting period to seven years, but it also expanded the restriction to cover the Under Secretary of Defense for Policy position, an ES Level 3 position and one of five DOD Under-Secretaries. ${ }^{166}$ Current US Code also mandates that the four other DOD Under-Secretaries and the sixteen assistant secretaries “...be appointed from civilian life," but the law places no minimum time limits between active service and appointment for these positions. ${ }^{167}$ The Secretaries of the respective services, Army, Navy, and Air Force, require a five-year separation between active-duty service and a civilian appointment. ${ }^{168}$ With few exceptions, statutes related to other executive department positions do not include similar mandates for appointees to come from civilian life. ${ }^{169}$

\footnotetext{
${ }^{164}$ National Defense Authorization Act of 2008

${ }^{165}$ National Security Act of 1947

${ }^{166}$ Section 903 National Defense Authorization Act of 2008

16710 USC $\$ 138$ (a)

16810 USC $\S 3013$. Four active-duty G/FOs have served as "acting" secretaries of their respective service during the period: Air Force General Merrill McPeak (Clinton), Admiral Frank Kelso (Clinton), and Army General Gordan Sullivan (Clinton). RSO Hanford T. Johnson (Air Force General (ret)) served as acting Secretary of the Navy under the Bush 43 administration.

${ }^{169}$ One interesting exception is the Director of the Federal Aviation Administration. A provision in the 1958 enacting legislation mandated the Administrator be a civilian. The conference report on the legislation stated that "the requirement that the Administrator be a civilian at the time of his nomination
} 
Despite the restrictions imposed by the 1947 Act, Congress allowed an exception for the DOD Secretary position only three years after its initial passage. Public Law 81788, passed on 18 September 1950, authorized General George C. Marshall to serve in the position of Secretary of Defense yet maintain his active-duty 5-star general rank. ${ }^{170}$ When granting this early waiver, however, Congress acknowledged the exceptional nature of this appointment, and advised against similar exceptions in the future. Section 3 of the 1950's legislation stated,

It is hereby expressed as the intent of the Congress that the authority granted by this Act is not to be construed as approval by the Congress of continuing appointments of military men to the office of Secretary of Defense in the future. It is hereby expressed as the sense of the Congress that after General Marshall leaves the office of Secretary of Defense, no additional appointments of military men to that office shall be approved. ${ }^{171}$ (Italics added)

The statute attests to the enormous public esteem and trust afforded to General Marshall, but it also showed that Congress recognized the importance of imposing and

means that he shall be a civilian in the strictest sense of the word. Thus, at the time he is nominated he may not be on the active or retired list of any regular component of the Armed Services or be on extended active duty in or with the Armed Services." This restriction remains in effect (49 U.S.C. §106) but has been waived on a regular basis by Congress, including the first director, General (ret) Elwood Quesada. Three more RSOs were appointed to the position prior to the Bush 41 administration, and in two cases legislation was passed which allowed them to remain on the retired list despite the restrictions in the original legislation. The other appointee, Colonel (ret) Alexander Butterfield, resigned his commission in order to expedite his nomination and with assurances he would be reinstated to the retired list upon completion of his FAA tour. However, the Senate denied his request to return his name to the retired list when he left the FAA. Two appointments are part of the period used in this study (Admiral (ret) James Busey IV, General Thomas C. Richards). See House Hearing Before the Subcommittee on Aviation of the Committee on Public Works and Transportation, $101^{\text {st }}$ Congress, 15 June 1989. http://congressional.proquest.com/congressional/result/pqpresultpage.gispdfhitspanel.pdflink/http\%3A\$ 2f\$2fprod.cosmos.dc4.bowker-dmz.com\$2fapp-bin\$2fgis-pubentry\$2fc\$2f1\$2f9\$2f0\$2fhrg-1989-pwt0005 from 1 to 36.pdf/entitlementkeys=1234

${ }^{170}$ Categorizing Marshall as a true "RSO" in this case is somewhat tenuous however. Army regulations at the time considered all 5-star officers on "active-duty" regardless of their true retirement status. Even though Marshall was technically on "active" status, he did not simultaneously hold a military position in DOD.

${ }^{171}$ Public Law 81-788 
adhering to statutory barriers in order to protect civilian control of the military. In effect, it implied that Congress acknowledged a special political status for RSOs as related to executive branch politics.

Returning to the Table 3.6 display, only the Veterans Administration (VA) and the Department of Transportation (DOT) approach DOD in the number of RSOs in ES level positions during the post-Cold War period. The VA positions raise little surprise. Appointing RSOs to VA positions easily aligns with expectations and traditions related to military camaraderie and loyalty to fellow soldiers that continue after military service. Moreover, three of the RSOs in the VA positions, one Bush 41 and two Bush 43 appointees, were medical doctors which significantly casts their military expertise in a different light. ${ }^{172}$

Of the 11 RSO appointments to posts in the Department of Transportation positions, three were retired Coast Guard Admirals, all Bush 43 appointees. The Coast Guard remained part of the Department of Transportation until the standup of the Department of Homeland Security, which makes the appointment of Coast Guard RSOs perhaps less surprising and comparable in kind to RSOs from the armed services that transition to DOD positions. RSOs from the traditional armed services that held Department of Transportation PAS appointments had rather unique competencies that are traditionally found in the military. These positions include, for example,

\footnotetext{
${ }^{172}$ The promotion process and career progression of military officers within the medical field is distinctly different from that of "line" officers. These differences do not diminish the impressive achievement of attaining a G/FO rank; however, the career paths of these officers is much more narrowly constrained within the medical field and thus not as "managers of violence." Claims of "military colonization" must take this important difference into consideration.
} 
Administrator of the Federal Aviation Administration (two Bush 41 appointments), and the Administrator of the Maritime Administration (Clinton appointee). Two RSO appointees did reach the Transportation deputy secretary level, an ES level 2 position: Navy Admiral James Busey (Bush 41) and Coast Guard Admiral Thomas Barrett (Bush 43).

As noted previously, few non-DOD ES positions specifically mandate that appointees come from civilian life. Despite the lack of prohibitions to active military officers, since 1989 only seven individuals remained on active duty while they served in an ES or White House PA position. These individuals are listed in Table 3.7 below. ${ }^{173}$

Table 3-7: G/FOs Serving in ES Positions While on Active Duty

\begin{tabular}{|cccc|}
\hline CIA & Director CIA & Bush 43 & General Michael V. Hayden (USAF) \\
CIA & Deputy Director CIA & Bush 41 & Admiral William O. Studeman (USN) \\
CIA & Deputy Director CIA & Clinton & General John A. Gordon (USAF) \\
CIA & Deputy Director CIA & Bush 43 & Admiral Albert M. Calland (USN) \\
DNI & Deputy Director National Intelligence & Bush 43 & General Michael V. Hayden (USAF) \\
WH & Deputy Nat'I Security Advisor & Bush 41 & Admiral Jonathan Howe (USN) \\
WH & Deputy Nat'I Security Advisor & Bush 43 & Lt General Donald Kerrick (USA) \\
WH & Deputy Nat'I Security Advisor & Bush 43 & Lt General Douglas Lute (USA) \\
\hline
\end{tabular}

\footnotetext{
${ }^{173}$ The Deputy National Security Advisor is not an ES position but rather a "PA" position but included because of its central role in National Security policymaking and regular target of "colonization" claims.

${ }^{174}$ General Hayden assumed the CIA position while on active-duty, but retired from the military during his tenure at the CIA.

${ }^{175}$ According to a LA Times report, Scowcroft wanted Howe to retire before accepting the position because he was not comfortable with an active-duty officer serving as deputy. Howe agreed to accept the position, however, only if he retained his 4-stars. The article suggests that Howe insisted on remaining in the active military primarily because he wanted to maintain his military housing privileges and accrue additional years for retirement benefits. See http://articles.latimes.com/1991-11-25/news/mn139_1_air-force.

${ }^{176}$ Kerrick also served on the NSC as the Director of European Affairs.

${ }^{177}$ Lute continued into the Obama administration as an active-duty officer, and currently remains in the position as an RSO
} 
Party affiliation of the respective administrations provides another factor to consider when examining the aggregate RSO totals. Since at least the early 1970s, the Republican Party has generally been perceived as more closely tied to strong defense measures, and studies suggest that the officer corps began to show a markedly stronger affiliation with this party after the Vietnam War. ${ }^{178}$ Although the Bush 41 administration levied the peace-dividend budget axe on the military, the popularity of the Gulf War offset animosities over the reduction and helped to solidify the Republican's image as the pro-military party.

The next Republican administration tried to further cement the relationship with Bush 43 prominently claiming "help is on the way" for the military after the putatively irresponsible and contentious Clinton years. ${ }^{179}$ Despite the campaign rhetoric, however, the tensions between senior military officers and civilian leaders during the Bush 43 administrations produced arguably even more contention than in the administration it followed. ${ }^{180}$ This observation suggests, therefore, that a higher level of RSOs doesn't necessarily correspond to a higher degree of consensus between the civilian executive branch and the uniformed military. In any case, the partisan data presented in Figure 3.5 offer an interesting consideration, but ultimately it provides only limited explanatory value. The data set contains three Republican terms and three Democratic terms, but

\footnotetext{
${ }^{178}$ Bacevich, The New American Militarism; Jason K. Dempsey, Our Army: Soldiers, Politics, and American Civil-Military Relations (Princeton, N.J.: Princeton University Press, 2009); Feaver, Armed Servants.

179 “George W. Bush Holds Campaign Rally in Grand Rapids, Michigan," November 3, 2000, transcripts.ccn.com/TRANSCRIPTS/022.03se.04.html

${ }^{180}$ Feaver and Seeler, "Before and After Huntington: The Methodological Maturing of Civil-Military Studies."
} 
the dominant number of G/FOs \& RSOs appointed by a single president, Bush 43, admittedly skews the results.

Figure 3-5: ES and Ambassador Appointments By Party

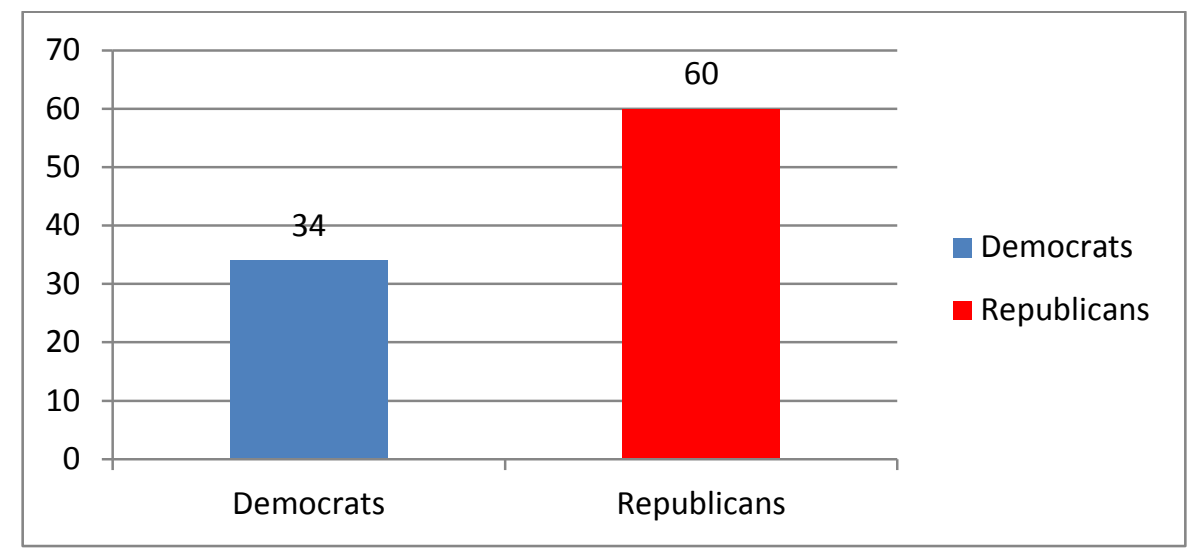

\section{9-11 and Executive Branch RSOs}

Any interpretation of the data across the respective administrations must prominently account for the impacts of the $9 / 11$. The September $11^{\text {th }}$ attacks occurred only nine months into the Bush 43 administration and ultimately initiated large scale changes to the executive branch. As a result, the executive structure of the Bush 43 and Obama administrations differed in important ways from the two earlier post-Cold War presidents. The most noticeable alterations were the standup of the Department of Homeland Security (DHS) and the organizational overhaul of the national intelligence community. The terrorist attacks occurred relatively earlier in Bush's administration but 
after the confirmations of most his first-term appointees. Figure 3.6 below shows the number of pre- and post- 9-11 G/FO appointments and suggests, at least for Bush 43, that the September $11^{\text {th }}$ attacks may be a significant factor in explaining the increase.

Figure 3-6: G/FO Appointments Before \& After Sept 11, 2001

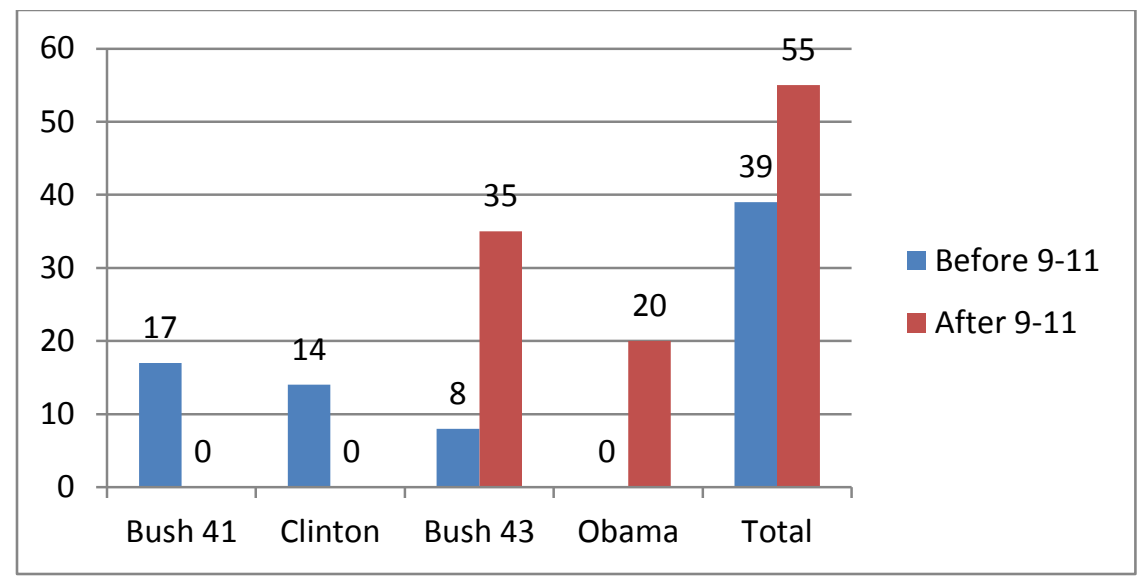

Established on 1 March 2003, DHS consolidated and reorganized many executive functions, and the reorganization created a number of new ES level positions related to national security. The standup of DHS added 18 PAS appointments, 6 PA appointments, 91 SES "general" billets, and 53 SES non-career appointment slots. ${ }^{181}$ These aggregate totals decreased marginally by the end of Bush's second term to 20, 1, 78, and 61 respectively. Bush 43 selected RSOs for three ES level 1-5 DHS positions during his two terms. One of these RSOs, retired Coast Guard Admiral James H. Loy, served as Deputy Secretary of Homeland Security, and for a short period in 2005 , as the acting Secretary

${ }^{181} 2004$ Plum Book 
of the department. Retired Navy Admirals Jay Cohen and David Stone were the other Bush appointees; the former served as the department's Under Secretary for Science and Technology (ES Level 3), and the latter as Assistant Secretary of Homeland Security, Transportation Security Administration. President Obama did not appoint any RSOs to DHS ES Level positions during his first administration.

The reorganization of the national intelligence community also must be taken into consideration when examining Figure 3.6. The Intelligence Reform and Terrorism Prevention Act of 2004 restructured the post-9/11 Intelligence Community (IC), which now includes a conglomeration of intelligence functions from 17 different agencies and departments. ${ }^{182}$ The Act created the position of Director of National Intelligence (DNI) to lead interagency coordination which represents the most far-reaching change stemming from the reorganization. ${ }^{183}$

Under the new structure, both Obama and Bush each appointed two Directors of National Intelligence. ${ }^{184}$ Of the four DNI appointments, RSOs accounted for three. Bush's first DNI appointment and sole non-RSO appointee, John Negroponte, left the position in 2007 and a RSO has occupied the position since. Aside from the director positions, the new Office of the Director of National Intelligence (ODNI) included four other ES positions: the deputy director (ES Level 2), Director of Counterterrorism (ES Level 2), Director of Counter-proliferation (ES Level 2), and a Chief Information Officer

\footnotetext{
${ }^{182}$ See 50 USC § 401a

${ }^{183}$ See ODNI website, http://www.dni.gov/index.php/about/history

${ }^{184}$ Bush 43 appointees: John Negroponte, Vice-Admiral (ret) John McConnell. Obama appointees: Admiral (ret) Dennis Blair, Lt Gen (ret) James Clapper
} 
(ES Level 4). Of the seventeen individuals who were nominated and confirmed for the ODNI positions since 2006, five were RSOs, and one, General Michael Hayden, occupied the deputy position while remaining on active duty; Bush nominated three of the RSOs and Obama selected two. ${ }^{185}$

Removing the DHS and DNI appointments from consideration for a moment provides a means to partially account for the differences in the pre- and post-9-11 executive branch structure. This modification removes seven Bush 43 appointments and two Obama appointments from the data set. With these deletions, Bush 43's revised total (36) still represents three-quarters of the combined total of the other three presidents. In other words, the creation of DHS and DNI cannot solely account for the increased presence of RSOs in the Bush 43 administration.

The enacting legislation for the Office of the Director of National Intelligence indicates that legislators contemplated civil-military issues when they created the leadership structure. The legislation, however, did not erect barriers to G/FOs and RSOs, but instead actually encouraged the appointment of commissioned officers to the either the director or principal deputy director post. The governing statute, 50 U.S.C. $\S$ 403-3a states:

\footnotetext{
${ }^{185}$ see Eileen Sullivan, "Robert Harding, Obama's Second TSA Nominee, Withdraws From Consideration," Huffington Post, March 27, 2010, http://www.huffingtonpost.com/2010/03/27/robert-harding-obamassec_n_515690.html. President Obama also withdrew the nomination of another RSO, Army Major General (ret) Robert A. Harding, who was originally nominated to an assistant secretary position as the head of the Transportation Security Administration in DHS. Harding withdrew in the face of a tough confirmation battle that resulted from his work as a defense contractor in Iraq and allegations of overpayment to his company.
} 
It is the sense of Congress that, under ordinary circumstances, it is desirable that one of the individuals serving in the positions (Director or Principal Deputy)...(A) be a commissioned officer of the Armed Forces, in active status; or (B) have, by training or experience, an appreciation of military intelligence activities and requirements. ${ }^{186}$

Although the legislation authorized active-duty commissioned officers to serve in these positions, the law specifically mandates that Department of Defense officials retain no supervisory authority over the appointed G/FOs. It further stipulates that their service in the positions, "shall not affect the status, position, rank, or grade of such officer in the Armed Forces, or any emolument, perquisite, right, privilege, or benefit incident to or arising out of such status, position, rank, or grade." ${ }^{187}$ The legislation encourages a military presence in either post, and it does not prohibit RSOs from filling both leadership positions.

The executive reorganization of the intelligence community also transformed the role of the Director of the CIA and severed the position's traditional direct relationship to the President. Despite the positions subordination to the DNI, the director still maintains a distinct public image, a point exemplified by the central place of the $\mathrm{CIA}$ director in the debate over the expanded use of lethal force via drones. ${ }^{188}$ Table 3.8 below lists each individual appointed to either the Director or Deputy Director position in the CIA during the four post-Cold War administrations. RSOs and active-duty G/FOs are noted in bold.

\footnotetext{
${ }^{186} 50$ U.S.C. $\S 403-403 a$

${ }^{187} 50$ U.S.C. $\S 403 \mathrm{C}(5)$

${ }^{188}$ Scott Shane, "C.I.A. to Expand Use of Drones in Pakistan," The New York Times, December 4, 2009, sec. International / Asia Pacific, http://www.nytimes.com/2009/12/04/world/asia/04drones.html.
} 
Table 3-8: Directors and Deputy Directors of the CIA

\begin{tabular}{|ccc|}
\hline Director & Bush 41 & Robert M. Gates \\
Deputy Director & Bush 41 & Admiral William O. Studeman (USN-active) \\
Director/Deputy Director & Clinton & George J. Tenet \\
Director & Clinton & John M. Deutch \\
Deputy Director & Clinton & R. James Woolsey \\
Deputy Director & Clinton & John E. McLaughlin \\
Deputy Director & Clinton & General John A. Gordon (USAF-active) \\
Director & Bush 43 & George J. Tenet \\
Deputy Director & Bush 43 & Admiral Albert M. Calland (USN-active) \\
Director & Bush 43 & Porter Goss \\
Deputy Director & Bush 43 & Stephen R. Kappes \\
Director & Bush 43 & General Michael V. Hayden (USAF active/retired) \\
Director & Obama & Leon Panetta \\
Director & Obama & General David H. Petraeus (USA-retired) \\
Deputy Director & Obama & Michael J. Morell \\
\hline
\end{tabular}

As shown in Table 3.8, a total of five G/FOs, two before 9-11 and three after, served in these CIA positions. Only the recently departed incumbent David Petraeus meets the strict definitional standards of an RSO. General Michael Hayden retired from the military during his tenure as director of the CIA and served as an RSO only for the last year of the administration. ${ }^{189}$

Excluding the CIA director and the DNI director, over half of the other 15 components of the Intelligence Community reside in the Department of Defense. Each military service contains its own component and four other agencies fall directly under

\footnotetext{
${ }^{189}$ Donna Miles, "Defense.gov News Article: Gates Praises Hayden as General Retires to Become Civilian CIA Director," American Forces Press Service, June 20, 2008, http://www.defense.gov/News/NewsArticle.aspx?ID=50268.
} 
the Office of the Secretary of Defense: the National Reconnaissance Office (NRO), the National Security Agency (NSA), the Defense Intelligence Agency (DIA), and the National Geospatial-Intelligence Agency (NGA). Nine individuals have directed the NRO in the post-Cold War period but only one was an RSO, Obama appointee General (ret) Bruce Carlson. The other three DOD agencies, however, have had a much stronger military presence. NGA has had five directors since the agency's inception in 1996 and only the current director has been a career civilian. The other four directors included three active-duty G/FOs and one RSO. The directors of the remaining two DOD intelligence agencies, the DIA and NSA, have always been active-duty military officers. Statutes dictate that the Director of the NSA must be an active-duty three-star officer or higher, but require that the deputy, "shall be a career civilian with cryptologic experience."190 The most recently named deputy director of the NSA, however, is an RSO, a retired Air National Guard brigadier general. The appointment of an RSO to the deputy position at NSA calls into question the true meaning of "career civilian" mandated by the governing statute. ${ }^{191}$

In a personal interview, a former Air Force general officer and DNI PAS appointee suggested that the nature of the intelligence profession would always make a strong military presence likely. He explained that the intelligence field, more so than any other interagency community, relies upon the highest level of interpersonal trust between its

\footnotetext{
${ }^{190}$ See DoD Directive 5100.20 paragraph 9(a)(b) http://www.dtic.mil/whs/directives/corres/pdf/510020p.pdf

${ }^{191}$ Although not included in the dataset because it followed Obama's first term, as of 21 December 2012 Air Force National Guard Brigadier General (ret) John C. Inglis holds the deputy position.

http://www.nsa.gov/about/leadership/bio inglis.shtml
} 
senior leaders. ${ }^{192}$ RSOs in the intelligence community commonly have close working relationships that extend across decades. The officer noted that he was "recruited" for his high-level position by a former mentor and close confidant, CIA director General Michael Hayden, based on their long-term interaction in military intelligence. A RSO closely familiar with Bush 43's first DNI chief appointment, John Negroponte, claimed that Negroponte himself was surprised that Bush named someone outside the intelligence community to lead the new agency. ${ }^{193}$ As an outsider to the intelligence world, Negroponte knew few of the "movers and shakers" in the insular and low-profile intelligence world, and according to the RSO familiar with his appointment, Negroponte found building the necessary trust relationships difficult.

The insular nature of the intelligence community, and the prominence of RSOs, ostensibly gives some credence to military colonization claims. But, the empirical data shows that RSOs have always been constant fixtures in the leadership of these agencies. Since the CIA's inception, for example, over one-third of its directors (8/22) and onethird of the deputy directors (8/24) have been G/FOs or RSOs. ${ }^{194}$ At times following the 2004 reforms, G/FOs or RSOs held 10 of the 17 senior Intelligence Community leadership positions simultaneously. Until recently, of the three highest intelligence positions in the nation, DNI, CIA, and NSA, RSOs occupied two of them (Clapper-DNI, Petraeus-CIA) and an active G/FO another(Army General Keith Alexander-NSA). The RSO status of the three most recent Directors of National Intelligence perhaps spurred

\footnotetext{
${ }^{192}$ Interview with former Air Force major general, 12 December 2012, Washington D.C.

${ }^{193}$ Interview with former Army four-star general, 16 January 2013, Crozet Virginia.

${ }^{194}$ These figures include both the Directors of Central Intelligence (DCI) and the Director of the Central Intelligence Agency after the 2004 reforms.
} 
awareness of the military's predominance in the intelligence community, but these appointments did not represent a change in kind.

The decreasing size of the military may influence the recent expansion in the number of RSOs in the intelligence community. The amorphous nature of the current threat environment, and the corresponding reduction in the overall strength of the military make the intelligence community an even more critical hedge in national security politics. In a 2010 oral history interview, former Vice-Chairman of the JCS, Admiral Jeremiah articulated this perspective:

When you are reducing your military, why would you also reduce your early warning? It doesn't make any sense, but that's something to remember to think about after the fact. You say that's really stupid and we discovered just how stupid it was in subsequent years trying to rebuild the intelligence capability broadly around the world after knocking it down. That was a terrible mistake. Everybody knows it and I don't think we'd do it again. ${ }^{195}$

In short, an increased RSO presence in the intelligence community may reflect a shift in prioritizing the tools of national security rather than any general expansion of military influence in the executive branch.

\section{Refining the Population: "Key" National Security Policy Positions}

To this point the analysis considered over 3,000 separate appointments which gave a more in-depth look into many departments and agencies. Nonetheless the numbers of individuals who truly steer national security policy making in any given

\footnotetext{
${ }^{195}$ Admiral David Jeremiah, “Miller Center Presidential Oral History Project," November 15, 2010, http://milllercenter.org/president/bush/oralhistory/david-jermiah.
} 
administration undoubtedly comprise only a small portion of this total. Isolating this small group of key national security policy positions, however, is tricky. The same positions often wield varied influence across and within administrations as well as across issue areas. Personality issues, personal relationships between senior leaders, levels of expertise in a given area, and the degree of opposition or shirking from career bureaucrats are only some of the factors that shape which officials have real influence in an administration. ${ }^{196}$ Notwithstanding these hurdles, the next filter refines the RSO search down to the 20 or so positions subjectively deemed to wield the most national security policy making influence. Appendix 3.1, column 1 annotates the positions captured by this filter. A large presence of RSOs in this key group would ostensibly vindicate purveyors of "military colonization" claims.

In Figure 3.7 below, the "Total G/FO" columns include all those key appointments of active, retired, and Coast Guard G/FOs. As the name implies, the “Armed RSO" columns include only RSOs who previously served in the Air Force, Army, Navy or Marine Corps. The "Total Vets" entry is once again shown as an indicator of the overall military flavor of the key grouping.

\footnotetext{
${ }^{196}$ See Lewis, The Politics of Presidential Appointments; Moe, "The Politicized Presidency."
} 
Figure 3-7: 25 "Key" Policy Positions

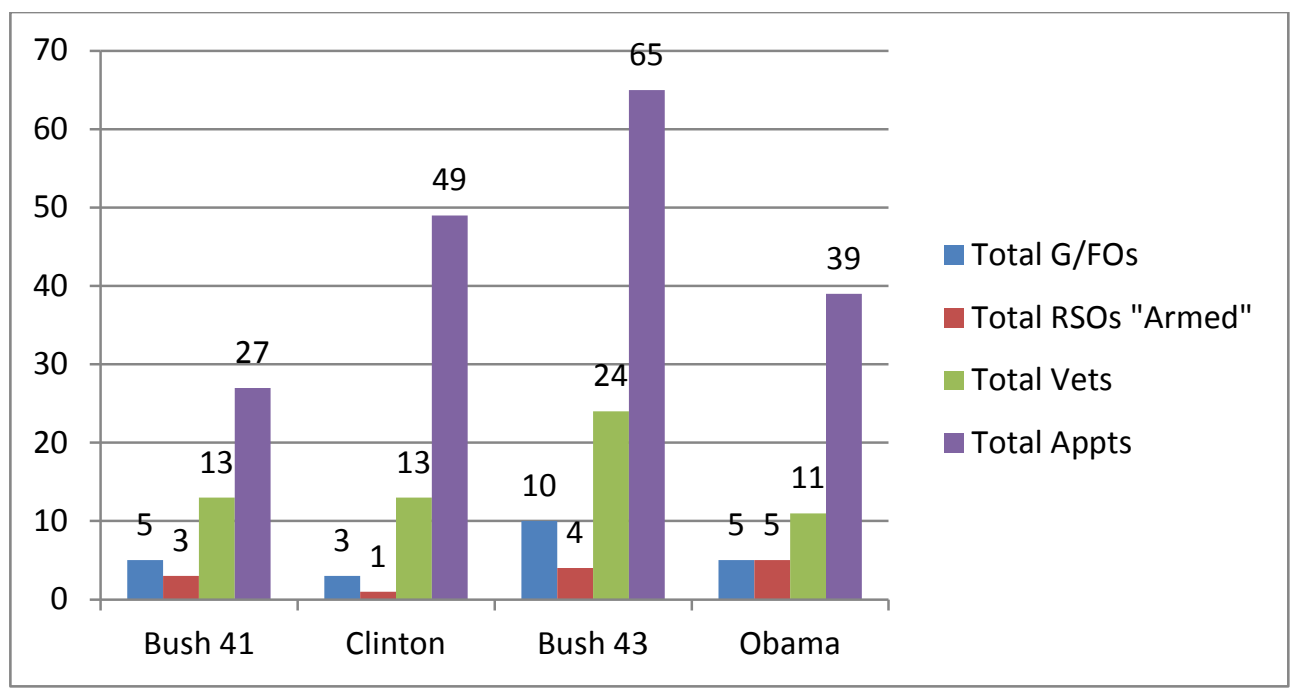

Of the 180 total appointments to the key positions twenty-three fall into the G/FO category. Eight of the twenty-three remained on active duty, three were retired Coast Guard admirals and the remaining eleven met the stricter RSO criteria. Of the eight active officers, Bush 41 appointed two (Admiral Jonathan Howe, Deputy National Security Advisor; Admiral William Studeman, Deputy Director of the CIA), Clinton two (General John Gordon, Deputy Director of the CIA; Lieutenant General Donald Kerrick, deputy assistant to the president for national security affairs), and Bush 43 the remaining four (Admiral Albert Calland, Deputy Director of the CIA; General Michael Hayden, Deputy Director DNI \& Director CIA; and Lieutenant General Douglas Lute, Deputy National Security Advisor for Iraq and Afghanistan). The Clinton administration shows the fewest overall G/FOs in key positions as well as the fewest RSOs. Lieutenant 
General Barry McCaffrey, the high-visibility White House Drug Czar appointee, represents Clinton's only key RSO.

Similar to the results found in the larger population of executive branch positions, Bush 43's total nearly doubles the combined total of the other three presidents in key positions. However, the "Total G/FO" entry masks some important characteristics of the appointments. First, both Coast Guard Admiral James Loy and General Hayden each served in two different positions and therefore they are effectively double counted. Removing Loy and the other Coast Guard RSO, Admiral Tom Barrett, from consideration makes a third of Bush's total disappear. Moreover, the only overlap of armed G/FOs (retired or active) in any of these Bush 43 key positions is a oneyear span when General Hayden served as the deputy DNI and Vice-Admiral Albert Calland served as the deputy director of the CIA. Breaking down Bush 43's total by term and excluding the Coast Guard RSOs, the president appointed one \& six G/FOs respectively. Bush juniors total therefore shows only one more $\mathrm{G} / \mathrm{FO}$ in his second term than either his father's or Obama's term, and his first term had less than Clinton's second. The narrower "Armed RSO" category shows Bush 43 in-line with both Bush 41 and Obama although Clinton still remains the exception. Based solely on these key position numbers, the RSO presence remained rather consistent across the post-Cold War period. Table 3.9 below provides the complete list of the key G/FOs. 


\section{Table 3-9: G/FOs in 25 "Key" National Security Positions}

\begin{tabular}{|ccc|}
\hline Deputy Director CIA & Bush 41 & Admiral William O. Studeman (USN-Active) \\
Secretary of Energy & Bush 41 & Admiral James D. Watkins (USN-RSO) \\
Deputy Secretary of Transportation & Bush 41 & Admiral James B. Busey IV (USN-RSO) \\
Nat'I Security Advisor & Bush 41 & Lieutenant General Brent Scowcroft (USAF-RSO) \\
Deputy Nat'I Security Advisor & Bush 41 & Admiral Jonathan Howe (USN-Active) \\
Deputy Director CIA & Clinton & General John A. Gordon (USAF-Active) \\
Drug "Czar" & Clinton & Lieutenant General Barry McCaffrey (USA-RSO) \\
Deputy Nat'I Security Advisor & Clinton & Lieutenant General Donald Kerrick (USA-Active) \\
Deputy Director CIA & Bush 43 & Admiral Albert M. Calland (USN-Active) \\
Director CIA & Bush 43 & General Michael Hayden (USAF-active/RSO) \\
Und Secretary of Transportation for Security & Bush 43 & Admiral James Loy (USCG-RSO) \\
Deputy Director National Intelligence & Bush 43 & General Michael Hayden (USAF-active) \\
Director of Counterterrorism Center & Bush 43 & Vice Admiral John S. Redd (USN-RSO) \\
Deputy Secretary of Homeland Security & Bush 43 & Admiral James Loy (USCG-RSO) \\
Director of National Intelligence & Bush 43 & Vice Admiral John M. McConnell (USN-RSO) \\
Secretary of State & Bush 43 & General Colin Powell (USA-RSO) \\
Deputy Secretary of Transportation & Bush 43 & Admiral Thomas Barrett (USCG-RSO) \\
Deputy Nat'I Security Advisor & Bush 43 & Lieutenant General Douglas Lute (USA-Active) \\
Director CIA & Obama & General David Petraeus (USA-RSO) \\
Director of National Intelligence & Obama & Admiral Dennis Blair (USN-RSO) \\
Director of National Intelligence & Obama & Lieutenant General James Clapper (USAF-RSO) \\
National Security Advisor & Obama & General James Jones (USMC-RSO) \\
Dep Nat'I Security Advisor (Afghan/Pakistan/S. Asia) & Obama & Lieutenant General Douglas Lute (USA-RSO) \\
\hline
\end{tabular}

Aside from the total numbers, the table also highlights some trends in the key positions.

All but four of the entries ('Armed RSOs' only) reflect appointments as the national security advisor (or deputy) or to an intelligence position: McCaffrey, Watkins, Busey, and Powell stand as the exceptions. The data also reveals a disproportionate number of Navy admirals compared with the other services. The Navy claimed double the number of the next highest service and Navy admirals held four out of five positions in the Bush 
41 administration. This last observation is interesting since it has traditionally been the Army which stokes usurpation fears. ${ }^{197}$

\section{RSOs and the National Security Council}

The PA position of Assistant to the President for National Security Affairs, more commonly known as the National Security Advisor (NSA) often serves as a lightning-rod for military colonization critiques. ${ }^{198}$ Therefore, this analysis momentarily expands the historical assessment beyond the Bush 41-Obama periodization to consider this particular position. ${ }^{199}$

The National Security Act of 1947 created provisions for a National Security Council, but the original legislation did not include the position of "Assistant to the President for National Security Affairs." The legislation instead created the nebulous position of "Executive Secretary." ${ }^{200}$ Truman's first Executive Secretary was an RSO, Rear-Admiral Sidney Souers, but the position resembled only a weak forerunner of the Assistant to the President for National Security Affairs position added by Truman's

\footnotetext{
${ }^{197}$ The Framer's even excluded the Navy from a key Constitutional provision aimed at ensuring civilian control of the military: the requirement that "...no appropriation of Money to that Use shall be for a longer Term than two Years" pertains only to the raising and supporting of armies. The practical significance of this observation is likely minimal but an interesting theoretical note nonetheless. ${ }^{198}$ see Cecil Van Meter Crabb and Kevin V. Mulcahy, American National Security: a Presidential Perspective (Pacific Grove, CA: Brooks/Cole, 1991). These authors present a typology that categorizes the leadership styles of former NSAs into 4 groups of increasing policy influence: "Administrator, Coordinator, Counselor, and Agent." It is an interesting note that all the RSOs and active officers were placed in the least influential category of "Administrator."

${ }^{199}$ Ackerman, The Decline and Fall of the American Republic, chap. 2; Ivo H. Daalder and I. M. Destler, In the Shadow of the Oval Office: Profiles of the National Security Advisers and the Presidents They Served-From JFK to George W. Bush (New York: Simon \& Schuster, 2009).

${ }^{200}$ Best, The National Security Council: An Organizational Assessment.
} 
successor. ${ }^{201}$ Under President Eisenhower the NSA position evolved to become a central coordinator of interaction between statutory members of the Council. Like his predecessor, Eisenhower selected an RSO as the first incumbent, retired Army Brigadier General Robert Cutler. Ike's close aide and staff secretary, Brigadier General Andrew Goodpaster, also informally served various functions now incorporated in the NSA position. ${ }^{202}$ McGeorge Bundy, Kennedy's NSA, described Goodpaster's role and the man himself as, "tending the door, and handling urgent messages silently-a wise and good man. ${ }^{\prime 203}$ Kennedy recognized Goodpaster's central role in the Eisenhower White House and requested the outgoing president delay the reassignment of Goodpaster so he could continue to perform the coordinating function in the new administration. ${ }^{204}$ Eisenhower noted in his diary:

Senator Kennedy was very much concerned with the activities of General Goodpaster, and said he would like to hold Goodpaster for two months into the new administration. I told him that I thought a better solution would be for him to appoint a man right now who could take Goodpaster's post (the duties of which I detailed at some length) and allow Goodpaster to leave with the rest of us on January 20. He said he would be handicapped unless he had Goodpaster for a month or two, really favoring the second. Of course I had to say that he would soon be the commander-in-chief and he could order General Goodpaster to do anything, and those duties would be efficiently performed; but I told him, also, of Goodpaster's great desire to go to active line duty and that a particular spot would be held. ${ }^{205}$

\footnotetext{
${ }^{201}$ Daalder and Destler, In the Shadow of the Oval Office, 3-5.

202 Best, The National Security Council: An Organizational Assessment; Daalder and Destler, In the Shadow of the Oval Office, 1.

${ }^{203}$ McGeorge Bundy, “Memorandum From President's Special Assistant for National Security Affairs to President Kennedy. 'The Use of the National Security Council,"' (U.S. Department of State, Foreign Relations of the United States, 1961-1963, Vol. XXV, Document 4, January 24, 1961), http://history.state.gov/historicaldocuments/frus1961-63v25/d4.

${ }^{204}$ Daalder and Destler, In the Shadow of the Oval Office, 7.

${ }^{205}$ Dwight D. Eisenhower, The Eisenhower Diaries, ed. Robert H. Ferrell (New York: Norton, 1981).
} 
Eventually Kennedy's own NSA, McGeorge Bundy, would expand on Goodpaster's role and set the mold for almost all NSAs that have followed.

While on active-duty, General Alexander Haig held the deputy NSA position for a period during the Nixon administration, but not until 1975 did an RSO occupy the primary post, Air Force Lieutenant General Brent Scowcroft. Scowcroft retired from the military in order to fill the position during the Ford administration, and he later served in the same position for Bush 41. In addition to Bush 41's appointment of Scowcroft, three other G/FOs have followed in the job since the Ford administration; two remained on active-duty during their tenure, Reagan appointees Admiral John Poindexter and General Colin Powell, whereas Obama appointee James Jones held the position as an RSO.

The practice of selecting active military officers or RSOs for the position of NSA has periodically incited some notable opposition, especially in the wake of the $1980 \mathrm{~s}$ Iran-Contra scandal. The triumvirate of retired Marine Corps Lieutenant Colonel Robert McFarlane, Admiral John Poindexter, and Lieutenant Colonel Oliver North, all Naval Academy graduates, invited piercing reconsideration of the relationship between military officers and the NSA, a discussion which continues to enliven appointments to the post. ${ }^{206}$ Nonetheless, the Iran-Contra fallout did not dissuade Reagan from naming another G/FO, General Colin Powell, as NSA in 1987, an appointment that in retrospect attracted relatively mild opposition. Civilian leaders in Congress expressed some

\footnotetext{
${ }^{206}$ See Timberg, The Nightingale's Song. Timberg's account suggests that a particular military worldview did indeed pervade the activities of the NSA during this time period, and he traces this worldview directly back to shared experiences as midshipman.
} 
opposition, but the strongest critiques came from Powell's fellow active G/FOs and RSOs. Prominent critics included, Chairman of the Joint Chiefs of Staff, Admiral Crowe, former Secretary of State and RSO Alexander Haig, and RSO Brent Scowcroft. ${ }^{207}$ Senator Tom Harkin proposed legislation in the $100^{\text {th }}$ and $101^{\text {st }}$ Congresses (both before $\&$ after Powell's appointment) to prohibit active duty commissioned officers from occupying the position but his bills made no reference to RSOs, and neither bill survived to committee consideration. ${ }^{208}$ Other key Senators justified Powell's appointment with logic reminiscent of RSO George Marshall's appointment to serve as Secretary of Defense. In a floor speech, Senator Sam Nunn, a key member of the Armed Services Committee that ultimately recommended confirmation stated, "Assignment of a military officer to this senior, sensitive position also raises serious questions about the civilian control of the military." Nevertheless, Nunn suggested that the recent turmoil in the NSC because of Iran-Contra validated the exception announcing, "I believe that this is a rather unique set of circumstances." The ranking Republican on the Armed Services Committee, John Warner, expressed similar ambivalence, but he too ultimately suggested that Powell had earned the trust of the nation. These Senate leaders ostensibly viewed institutional

\footnotetext{
${ }^{207}$ Colin L. Powell and Joseph E. Persico, My American Journey: An Autobiography (Random House, 1995), 349.

${ }^{208}$ Harkin proposed S.175 in 1987 while Powell awaited confirmation and in 1989 he resubmitted the bill as S. 395. Although the NSA position is not a PAS position, Powell still was confirmed by the Senate. Since all assignments of military 3-star and 4-star generals require Senate confirmation, in order for Powell to maintain his rank as a 3-star officer and not revert to his permanent two-star rank, Senate confirmation became required.
} 
impediments as overkill, although Powell himself had supported prohibitions on military officers as the NSA in an earlier New York Times interview. ${ }^{209}$

In his autobiography, Powell noted that he was reluctant to accept the NSA position because of concerns over how his fellow military officers would perceive the appointment, and how the assignment may impact his Army career. To minimize the potential resentments of fellow G/FOs, Powell recommended that his tasking come directly and publically from the Commander in Chief. In Powell's calculations, "That's the one thing my world will understand." ${ }^{210}$ His concern about the perceptions of his fellow officers suggests that G/FOs indeed recognize a distinct line between military and civilian policy making positions even if the positions directly relate to national security issues.

Like Powell, Obama's first NSA appointment, James Jones, owned an impressive military resume: commandant of the Marine Corps, NATO commander, and envoy to the Middle East during the Bush administration. Jones also had the reputation of someone willing to provide straightforward and independent assessments when solicited. ${ }^{211}$ Despite Jones' status as an RSO, however, frequent acerbic conflict with senior active duty military leaders characterized much of his tenure as NSA. ${ }^{212}$ Jones's less than two-year tenure challenges assertions that RSOs simply add an echo of

\footnotetext{
209 Powell and Persico, My American Journey, 352; ibid., 350.

${ }^{210}$ Christopher D. O'Sullivan, Colin Powell : American Power and Intervention from Vietnam to Iraq (Lanham, Md.: Rowman and Littlefield, c2009.), 36.

211 John Barry, Dan Ephron, and Richard Wolffe, "The General's Marching Orders," Newsweek 152, no. 23 (December 8, 2008): 8-9.

212 Bob Woodward, Obama's Wars (New York: Simon \& Schuster, 2010).
} 
Pentagon worldviews and policy preferences into the close circle of White House civilian advisors. In Obama's Wars, author Bob Woodward argued that the administration selected Jones precisely because, “...his record of outspokenness and independence might make him a counterweight to the military establishment." ${ }^{213}$ Woodward cites Jones's role in providing Obama an independent assessment of the evolving Afghanistan strategy which encouraged the president to resist the military leadership's call for an expanded counterinsurgency effort and the corresponding troop increases. Jones was a valuable advisor to a young, untested, and inexperienced new president and served an important role in ensuring an appropriate level of skepticism on military advice during the policy making process. ${ }^{214}$ Despite Jones's contributions, his tenure as NSA has not been judged favorably by scholars and pundits. ${ }^{215}$ Nonetheless, in terms of RSO behavior in key positions, Jones's example is enlightening. Far from exemplifying a domineering and military centric figure, characterizations of Jones's tenure instead suggest it as "one of the weakest and most isolated NSAs since the creation of the National Security Council (NSC) in 1947."216

\section{Ambassadors and RSOs}

Ambassador appointments technically fall outside the ES system but they nonetheless still require presidential appointment and Senate confirmation. The unique

\footnotetext{
213 Ibid., 38.

${ }^{214}$ Kevin Marsh, "The Administrator as Outsider: James Jones as National Security Advisor," Presidential Studies Quarterly 42, no. 4 (December) (2012): 831; Woodward, Obama's Wars, 123.

${ }^{215}$ Marsh, "The Administrator as Outsider: James Jones as National Security Advisor"; I. M. Destler, "Donilon to the Rescue?," Foreign Affairs, October 13, 2010, http://www.foreignaffairs.com/articles/66772/i-m-destler/donilon-to-the-rescue.

${ }^{216}$ Marsh, "The Administrator as Outsider: James Jones as National Security Advisor," 828.
} 
nature of ambassador appointments makes them worthy of some additional scrutiny.

While officials from the career Foreign Service fill most ambassador assignments, presidents also traditionally use some of the posts as plum rewards for the most loyal political supporters and donors. Figure 3.8 below shows the number of career Foreign Service members appointed to ambassador positions versus the number of non-career appointments. The latter represent those assignments normally associated with patronage or other political concerns. The display of career versus non-career appointments alongside the number of RSO appointments, puts the limited presence of former senior military officers in some context. ${ }^{217}$

\footnotetext{
${ }^{217}$ This data is based on a search of the legislative records for the Senate Foreign Affairs committee nominations. All ambassador nominations to individuals not listed as "members of the career foreign service", are included in the total with one exception; in some cases the title "ambassador" was assigned to senior members of the state department as a recognition of career service despite not filling an ambassadorial position; these individuals are not included in the total. Both Bush 43 appointments to RSOs were "Coordinators for Counterterrorism with rank of Ambassador at Large." Those given the ambassador title while filling a prominent role in peace or treaty negotiations are also included.
} 


\section{Figure 3-8: Ambassador Appointments}

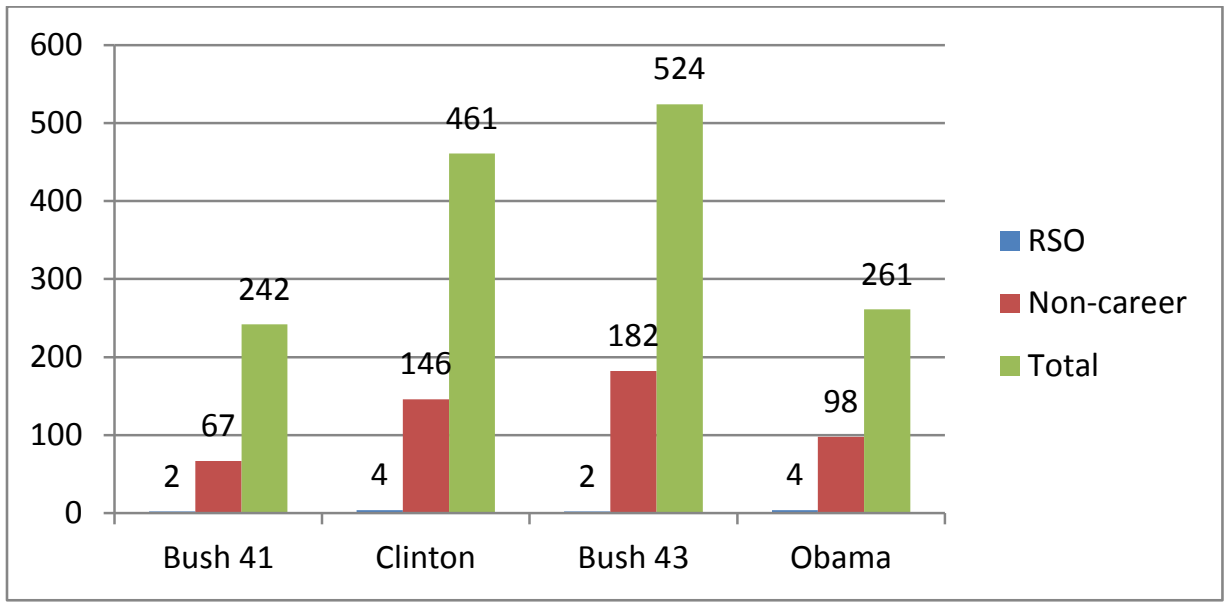

In certain respects, there is no reason to expect any RSO presence in ambassador positions just as there is virtually no reason to expect an appointment of a career foreign service official to a senior military position. However, RSOs gain tremendous foreign experiences and international connections during their senior military postings, and they develop competencies that ostensibly make them credible candidates for such positions. Nevertheless, of the nearly 1,500 ambassador appointments, presidents appointed only 12 RSOs to ambassadorships between 1989 and $2012 .{ }^{218}$ Expanding the RSO pool to include retired colonels adds only an additional six appointments. Table 3.10 below lists the 12 RSO appointments during the period and shows that RSO ambassador appointments are dispersed among former ranks as well as service branches.

\footnotetext{
${ }^{218}$ This listing only includes those confirmed as ambassadors. Clinton notably tasked Colin Powell as a special envoy during the Haitian crisis and Bush 43 appointed RSO General Anthony Zinni as the special envoy to the Middle East.
} 


\section{Table 3-10: RSOs Appointed to Rank of Ambassador}

\begin{tabular}{|ccc|}
\hline Lieutenant General Vernon Walters (USA) & Bush 41 & Ambassador, Federal Republic of Germany \\
Major General Robert Kimmitt (USAR) & Bush 41 & Ambassador, Federal Republic of Germany \\
Major General Jerome Cooper (USMCR) & Clinton & Ambassador, Jamaica \\
Admiral William Crowe (USN) & Clinton & Ambassador, United Kingdom \\
Admiral Joseph Prueher (USN) & Clinton & Ambassador, China \\
Brigadier General Francis Taylor (USAF) & Bush 43 & Amb at large--Coordinator for Counterterrorism \\
Lieutenant General Dell Dailey (USA) & Bush 43 & Amb at large--Coordinator for Counterterrorism \\
Lieutenant General Karl Eikenberry (USA) & Bush 43 & Ambassador, Afghanistan \\
Major General Alfonso Lenhardt (USA) & Bush 43 & Ambassador, Tanzania \\
Brigadier General James Smith (USAF) & Obama & Ambassador, Saudi Arabia \\
Major General Jonathan Gration (USAF) & Obama & Ambassador, Kenya \\
\hline
\end{tabular}

\section{The Longer Historical Picture}

The findings presented so far provide a summary of the presence of RSOs in the executive branch over the last quarter century and post-Cold War years, but how does the period compare with the entire post-World War II period? An equally in-depth review of executive branch appointments from Truman to Reagan is beyond the scope of this study, but it is practical to examine at least the key positions. Historical changes in the composition of the cabinet and the national security apparatus over the last 60 plus years complicate a direct comparison across all the administrations. Nevertheless, focusing on the cabinet officers, deputies, and key White House staff members makes a rough comparison possible. Figure 3.9 below displays post-World War II G/FO appointments to the highest executive branch positions and particularly those related to 
national security. ${ }^{219}$ Presented in this manner, Bush 43 no longer appears as such a

dramatic outlier, and in general, the longer time frame actually shows rather notable

consistency. ${ }^{220}$ The longer historical look also highlights a significant disparity across

parties. Within the key positions, post-World War II Democrats appointed G/FOs \&

RSOs to 18 positions, whereas Republicans appointed 31 during the period, albeit with

two additional presidential terms.

\footnotetext{
${ }^{219}$ See Appendix 3 for the list of G/FOs and RSOs from Truman through Reagan. As mentioned earlier, determining "key" positions across administrations is wrought with pitfalls. The population included in this analysis for presidents from Truman to Reagan include all cabinet positions, the directors of the budget, directors and deputy directors of the CIA, Chiefs of Staff and deputy chiefs of staff, deputy secretaries of Defense, State, \& Justice, Directors of the FBI, Service Secretaries, and all members listed as part of the National Security Council and its staff. For example, the United States Government Manual, published annually, formerly included positions such as Director, Office of Emergency Preparedness or Chairman, National Security Resources Board as members of the NSC; these positions were thus included as "key" positions. Biographical information was obtained primarily from online presidential museum sites; in cases where info could not be found on these sites, a myriad of other publically accessible and credible internet sources were used. For presidents from Bush 41 to Obama, the same group of 25 "key" policy makers included in the preceding analysis was used again in this chart. See appendix 3 for list of RSOs.

${ }^{220}$ An interesting observation from the graph above is that the Kennedy-Johnson years, and the large expansion of the military related to the escalation in Vietnam, shows the smallest number of G/FOs and RSOs in key positions. In his diary, President Eisenhower noted that the newly elected Kennedy showed some degree of surprise at the number of responsibilities that military officers held in the administration. In a December 1960 entry Eisenhower wrote: "The senator seemed to be a bit amazed when I told him about the great numbers of people that operate in the Signal Corps, Transportation and Evacuation activities, all under the military aides" (Eisenhower Diaries, 381). Kennedy's only RSO appointment was Lieutenant General Marshall S. Carter as the Deputy Director of the CIA. Although not reflected in the data, RSO General Maxwell Taylor, however, played a critical role as a special advisor to the Kennedy Administration and he was a key contributor to the administration's "Flexible Response" doctrine. At the behest of JFK, Taylor returned to active duty as Chairman, Joint Chiefs of Staff, and after retiring a second time, he returned as an official advisor to Johnson and ultimately as Ambassador to Vietnam. Taylor is not included in the data because he did not hold an official ES or PA position and ambassadors are not considered "key"; however, his highly publicized opposition to Eisenhower's "New Look" program, and his central role in national policy toward Vietnam during the 1960s, shows that the period was not devoid of "celebrity" generals or important RSO influence. Other figures, such as Curtis Lemay and William Westmoreland further serve as examples that reinforce this point. See, Russell Frank Weigley, History of the United States Army, (Bloomington, IN: Indiana University Press, 1984), and Maxwell D. Taylor, The Uncertain Trumpet, (New York: Harper, 1960).
} 
Figure 3-9: Post-WWII G/FO "Key" Appointments

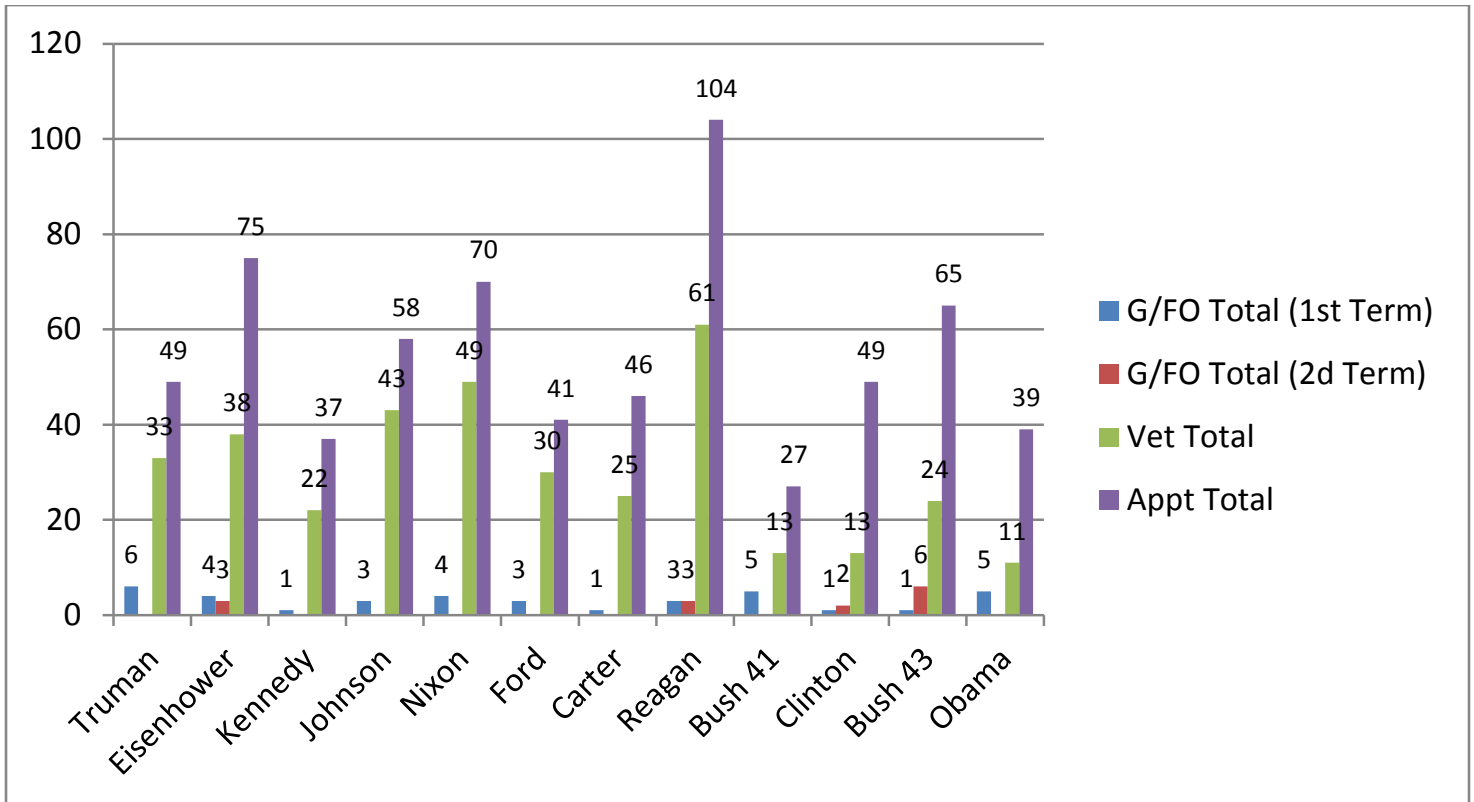

RSOs and the Senior Executive Service: A Short Case Study

In addition to ES Level positions, PA positions, and ambassadorships, presidential appointees to SES positions can also have considerable policy making influence. In terms of executive responsibilities and pay levels, many SES positions equal or even exceed those of ES appointees. SES pay is much less standardized than the ES level positions and it is becoming increasingly tied to performance incentives. Based on published information on the Office of Personnel Management (OPM) website, SES pay ranges from $\$ 119,554$ to $\$ 179,700$, and average salaries are roughly equivalent to ES Level III. Consistent with assumptions discussed earlier, if pay reflects a reasonable 
measure of responsibility and influence, then many members of the SES serve at a responsibility level comparable to those in the ES system. ${ }^{221}$

The following case study specifically focuses on SES appointments in the Department of Defense. DOD contains the largest number of SES personnel and any discussion regarding national security policy or civilian control of the military naturally must focus heavily on this department. ${ }^{222}$ Moreover, the military expertise of RSOs ostensibly translates into competencies required in high-level DOD SES positions. Moreover, the size of the civilian DOD workforce simply makes RSO employment in this department statistically more likely. ${ }^{223}$

The figures below reflect information provided by DOD's Office of Civilian Personnel Management (CPM) and include aggregate SES data beginning in 2005. A CPM official reported that her office did not maintain releasable data on years prior to 2005. The limited span of this data makes the analysis less valuable for examining trends across the post-Cold War period, but it nevertheless provides an interesting snapshot of the personnel composition of DOD. The data set contains over 750 SES appointments and includes the former military rank and veteran status of those who occupied SES positions. The figures unfortunately cannot account for all DOD SES members. Members appointed prior to 2005 and who remained in their positions during

\footnotetext{
${ }^{221}$ Retrieved from Office of Personnel Management website, 7 Nov 2012 http://www.opm.gov/ses/facts_and_figures/data_trends10.asp

${ }^{222}$ See OPM data, http://www.opm.gov/feddata/factbook/\#2007

${ }^{223}$ Curtis W. Copeland, The Federal Workforce: Characteristics and Trend. Congressional Research Service Report,19 April 2011. Accessed 7 Nov 2012. http://assets.opencrs.com/rpts/RL34685 20110419.pdf
} 
2005-2012 elude measurement. Nonetheless, the period provides a valuable snapshot over two different presidencies, and partisan administrations. Figure 3.10 below displays the number of RSOs among the DOD SES appointments.

\section{Figure 3-10: RSOs in the SES--Career \& Non-Career}

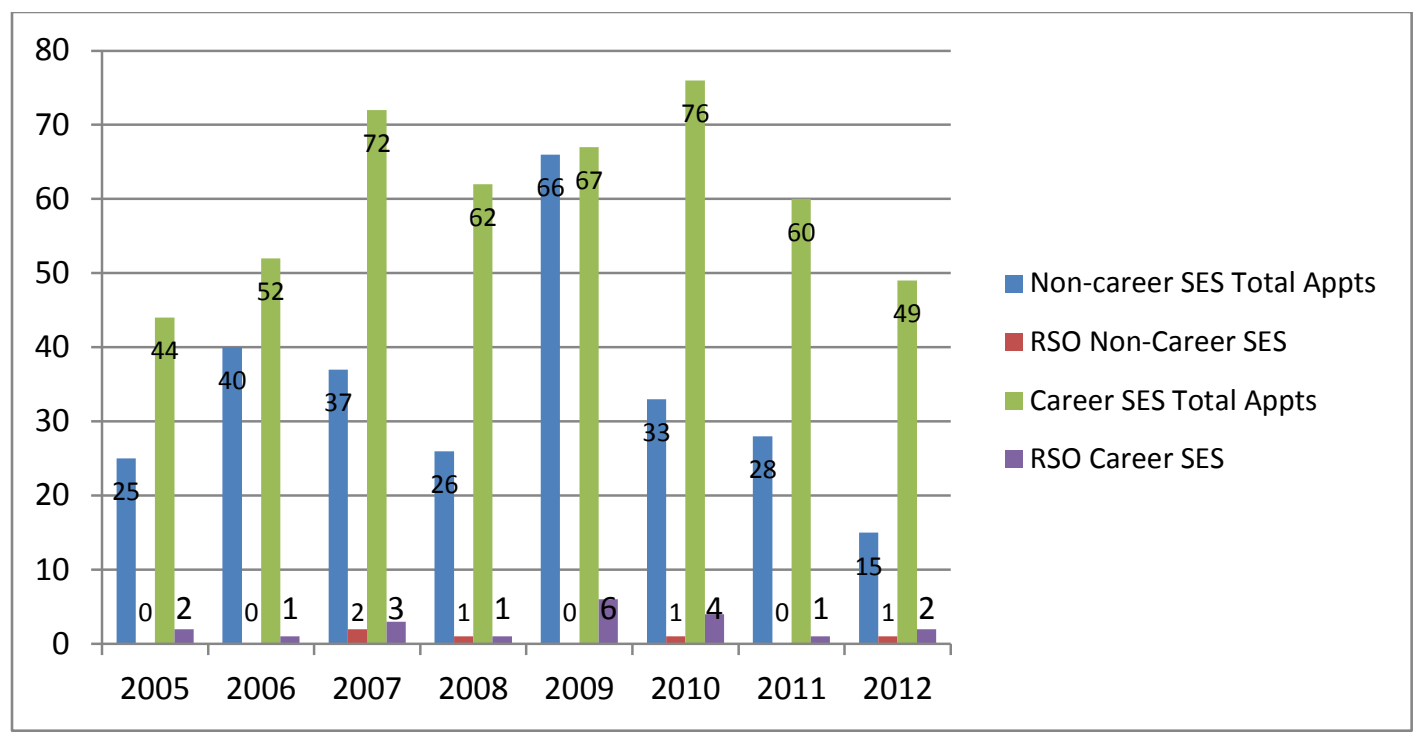

As Figure 3.10 shows, perhaps somewhat surprisingly, only five RSOs received presidential appointments to a Non-career or excepted SES positions from 2005-2012 in the Department of Defense. RSOs earned 20 Career SES positions over the time period, but considering the total number of appointments, even this seems a rather small figure. Further highlighting the relative scarcity of RSO SES appointments, Figure 3.11 below compares the total SES appointments, Career and Non-career, in the Department of Defense with the number of G/FOs that retired in each respective year. ${ }^{224}$ The data clearly shows that if RSOs are pursuing federal SES positions, it is only marginally within DOD.

\footnotetext{
${ }^{224}$ Retirement data provided by the Office of the Actuary, Department of Defense, http://actuary.defense.gov/. The retirement figures for FY2012 are not yet published.
} 


\section{Figure 3-11: RSO SES Appointments vs. Retirements}

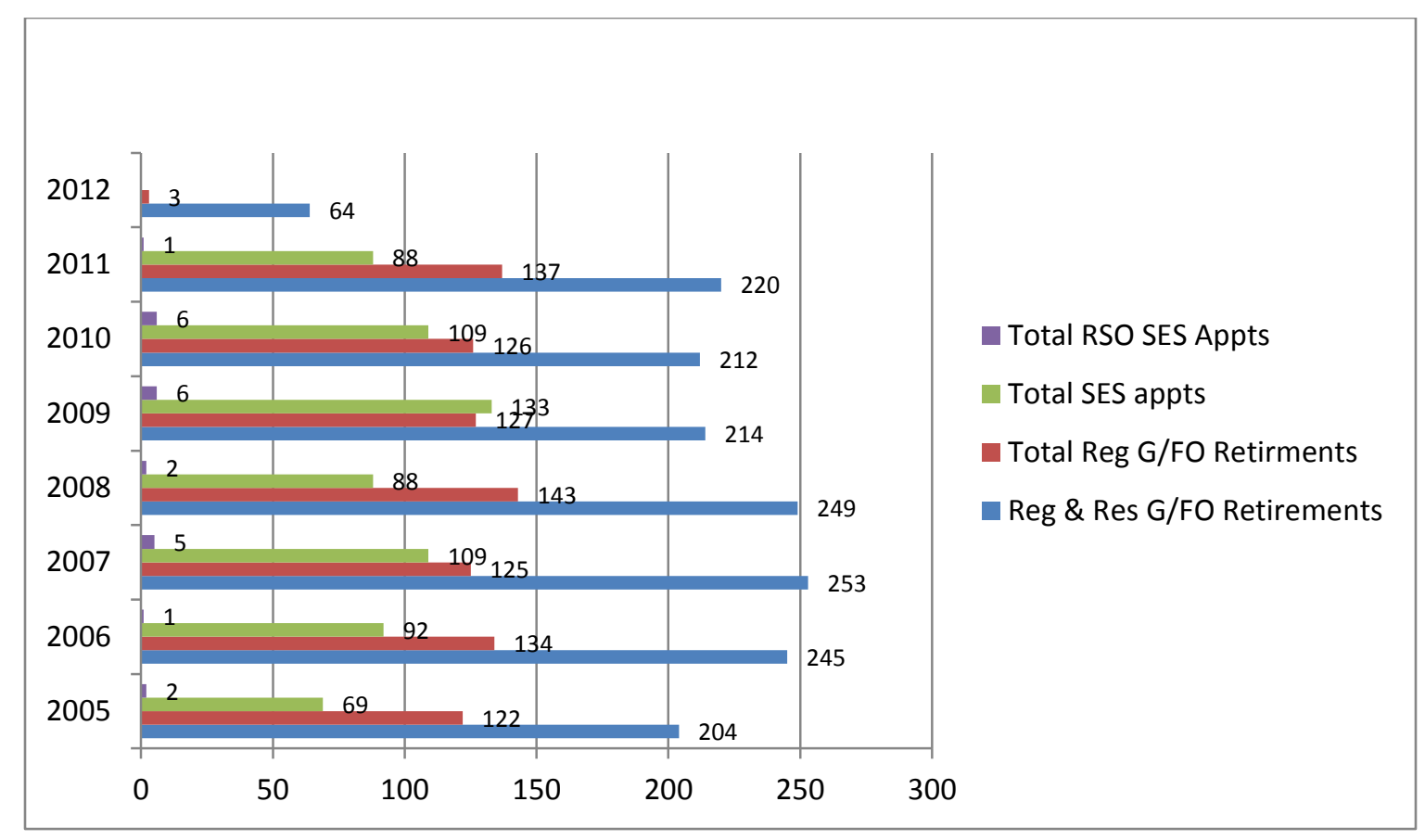

Although RSOs appear to have only a minimal presence in Defense SES positions, veterans overall comprise a much higher portion of career positions. Figure 3.12 below illustrates their numbers. So, if Defense SES positions do not reflect a strong contingent of RSOs, what types of veterans do enter the SES? Figure 3.12 also displays the number of retired Colonels (Navy Captains included) who entered the career SES in DOD. 
Figure 3-12: Career SES Appointments 2005-2012 Vets \& Colonels

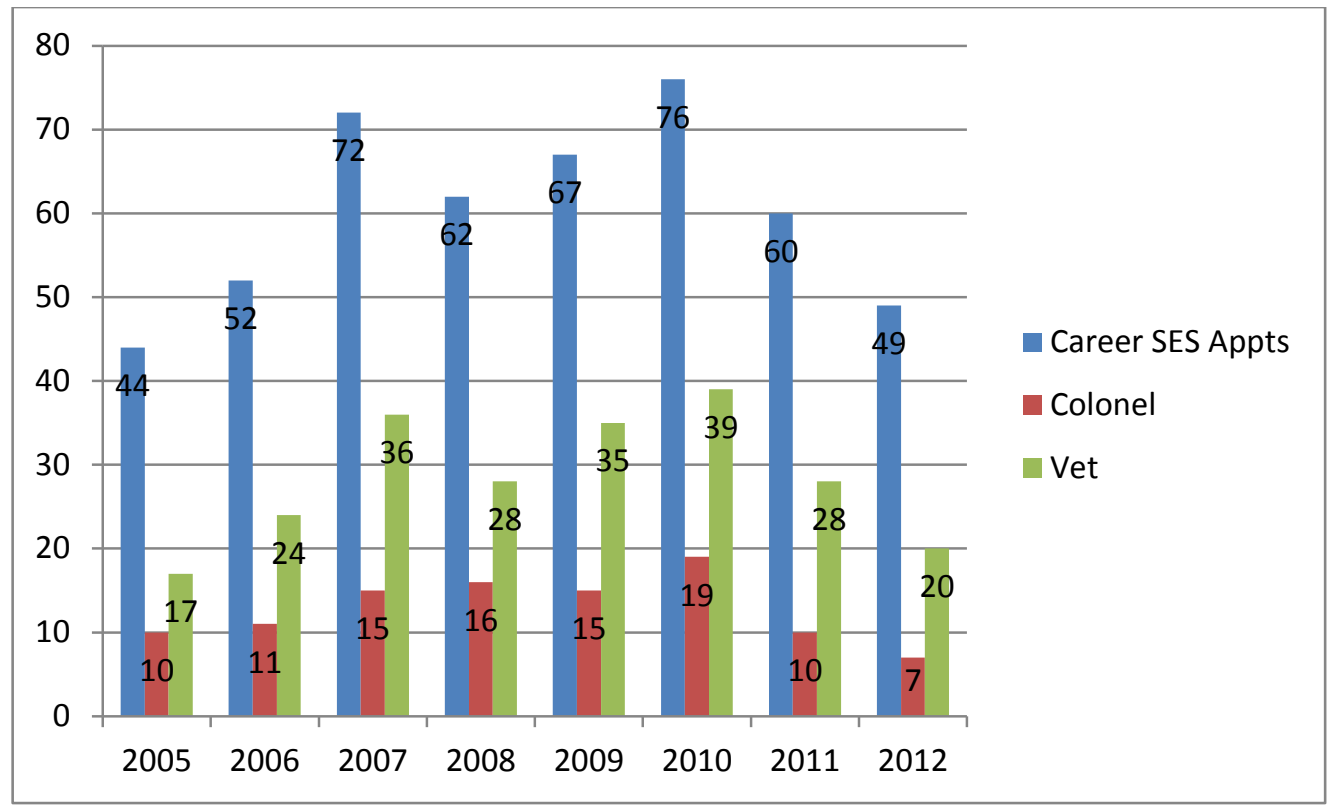

\section{Figure 3-13: Non-Career SES Appointments 2005-2012 Vets \& Colonels}

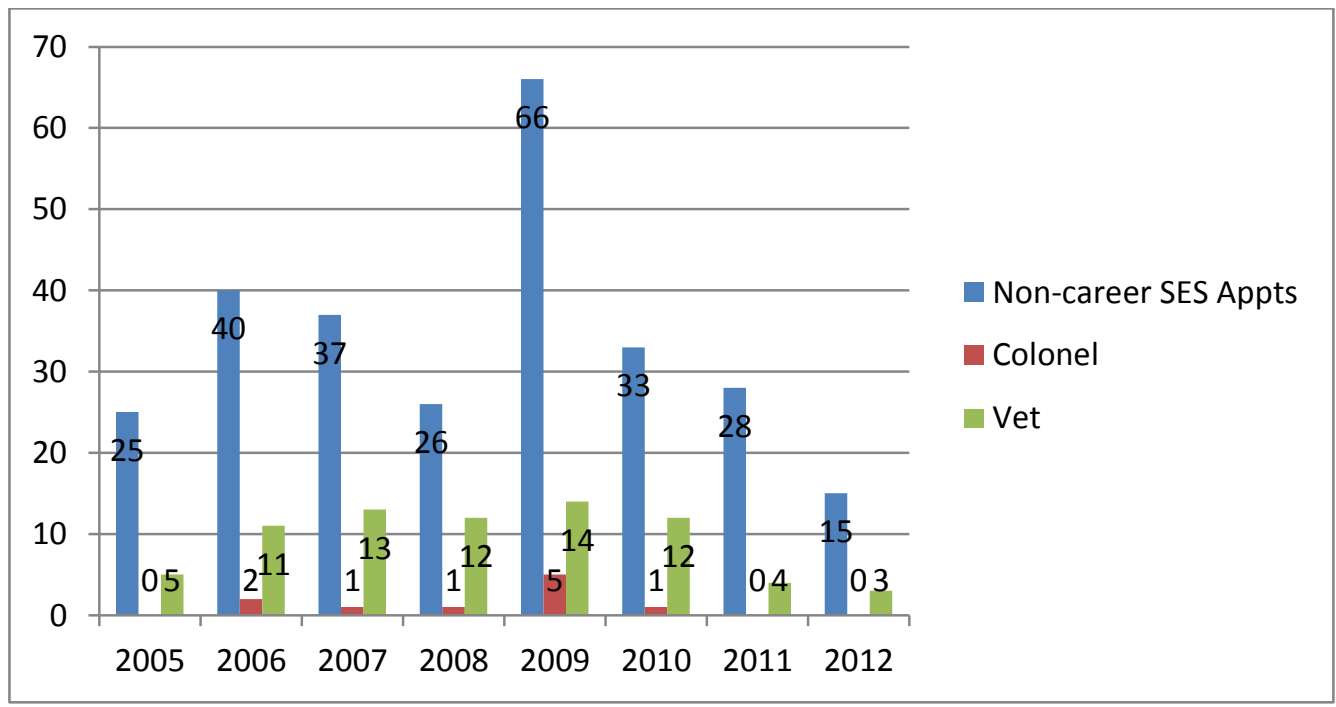

In the U.S. military, "Colonel" is considered a "senior" rank and these officers

often wield considerable policy making influence while on active duty. Colonels, or Navy Captains, command entire air bases, aircraft carriers, and army battalions that often 
contain upwards of 5,000 troops and they also lead important staff organizations. There are far more colonels than G/FOs (see Chapter 2, Table 2.1), and on average they also retire at a younger age, although not considerably so. Based on 2011 data, the average retirement age of a colonel was 51.2 years whereas a one-star $\mathrm{G} / \mathrm{FO}$ was 53.2 , increasing by two years for ever subsequent star. Despite their increased presence in comparison to RSOs, however, colonels never represent even $25 \%$ of total SES placements in any given year. This data suggests that further studies of military colonization must go beyond just G/FOs and RSOs and examine the large subset of slightly lower ranking retired officers that appear to have a significant presence in the executive branch, at least in the DOD.

\section{RSOs and Indirect Executive Branch Service}

RSOs also interact with the executive branch in less direct ways. For example, in an effort to capitalize on the experiences and expertise of RSOs, Congress authorized the Department of Defense to employ a number of former officers as "Senior Mentors." ${ }^{225}$ This previously obscure program came under heavy public scrutiny in 2009 following a USA Today investigative report that highlighted the pay received by RSOs in the program and the potential for conflicts of interest. ${ }^{226}$ The USA Today article revealed that the government compensated Senior Mentors up to $\$ 330$ dollars per hour

\footnotetext{
${ }^{225}$ See Tom Vanden Brook, Ken Dilanian, and Ray Locker, "Retired Military Officers Cash in as Well-Paid Consultants," USA Today, November 18, 2009.

${ }^{226}$ Tom Vanden Brook, Ken Dilanian, and Ray Locker, "Retired Military Officers Cash in as Well-Paid Consultants," USA Today, November 18, 2009.
} 
or nearly three times their previous active-duty salaries. More controversial, however, the report revealed that many of these Senior Mentors concurrently served on the Boards' of Directors for defense sector companies that were actively pursuing large government contracts. ${ }^{227}$ As the journalists noted, nothing in the program technically violated federal statutes but the findings forced a reconsideration of the role of RSOs with respect to DOD.

In the wake of the USA Today article, the Secretary of Defense issued a policy memorandum which required all senior mentors to convert to a status of Highly Qualified Experts (HQE) by 30 June 2010. The memorandum defined Senior Mentor as:

....a retired flag, general or other military officer or senior retired civilian official who provides expert experience-based mentoring, teaching, training, advice, and recommendations to senior military officers, staffs and students as they participate in war games, war fighting courses, operational planning, operational exercises, and decision-making exercises."228

The change from Senior Mentor to HQE signified much more than simply a name change. The label of HQE already existed in public laws which put restrictions on the levels of pay and also mandated more stringent financial disclosure requirements for participating RSOs.

The Secretary of Defense's April 2010 memorandum also mandated that the DOD Inspector General (IG) conduct an audit of the senior mentor program. The IG

\footnotetext{
${ }^{227}$ Citizens for Responsibility and Ethics in Washington (CREW), Strategic Maneuvers: The Revolving Door from the Pentagon to the Private Sector, November 2012, http://www.citizensforethics.org/page//PDFs/Reports/CREW_Strategic_Maneuvers_Pentagon_Generals_Revolving_Door_11_15_12.pdf?nocdn= 1.

${ }^{228}$ Secretary of Defense Policy Memorandum, "Policy on Senior Mentors", 1 Apr 2010
} 
audit revealed that the Army began employing Senior Mentors in the late 1980s and the other services followed suit beginning in 2000. The report detailed that in FY2010, DOD employed a total of 355 mentors. ${ }^{229}$ Most of these mentors were hired through contracts with defense firms, not as independent contractors, and therefore they were not required to submit individual financial disclosures.

Following the new guidance to convert Senior Mentors to HQEs, the vast majority of RSOs quit the program. The statutory requirements of the HQE program also mandated that DOD publically release the names of senior mentors and the most current list, dated 1 Oct 2012, shows only 36 participants. ${ }^{230}$ All but three of these participants were RSOs. ${ }^{231}$ The 33 RSOs on the list included two retired four-stars, fifteen 3-stars, nine 2-stars, and retired one-stars held the remaining fourteen positions. One RSO in the group retired before 1997 but all the others retired evenly over the last 10 years.

In an effort to determine their rationale for leaving the program, the Inspector's General study queried a sample of former participants. According to the report, RSOs overwhelmingly cited the new financial disclosure requirements, the limits to compensation, and also how participation threatened their opportunities for

\footnotetext{
${ }^{229}$ Department of Defense Inspector General, DoD Complied With Policies on Converting Senior Mentors to Highly Qualified Experts, but Few Senior Mentors Converted (Department of Defense, October 31, 2011).

${ }^{230}$ http://www.cpms.osd.mil/sespm/docs/2012-Oct-1_Senior-Mentors.pdf

${ }^{231}$ The remaining 3 included two career foreign service officers and no biographical data could be found on the other.
} 
employment in the private sector, as the main factors in their decisions to resign from the program.

\section{Considering Military Promotions as Political Appointments}

Aside from the Senior Mentor diversion, the central focus in this chapter has been on presidential appointments to civilian executive branch positions. However, presidential appointments within the military also represent an important consideration in the RSO-executive branch relationship. Officer commissions within the military reflect presidential "appointments" and also require Senate approval. To close this chapter, it is therefore worthwhile to briefly consider the political nature of G/FO appointments and their potential relationship to later RSO placements in the civilian executive branch.

All military officer commissions and appointments legally require presidential nomination and Senate approval. Up through and including the rank of Major General (or Navy Rear-Admiral) the institutional military holds a great deal of autonomy in the promotion process. The confirmation process for ranks below G/FO follows a rather routine administrative procedure where the president nominates and the Senate confirms large cohorts of officers simultaneously through well-established promotion cycles. In promotions through the ranks of colonel (or "captain" in the Navy), arguably no other system better epitomizes a more meritocratic process. Characteristics of the promotion system change significantly, however, for the G/FO ranks, especially for three 
and four stars. Centralized ad hoc boards of existing G/FOs select one and two-star officers. Political interference with these boards, whether by military or civilian leaders, represents a serious breach of institutional trust. ${ }^{232}$ Promotions from two-star and three-star, and again from three-star to the pinnacle four-star rank, embody their own mystique to all but those intimately involved in the selection process. Thomas Ricks, a prominent defense correspondent suggests that, " $[T]$ he deliberations of promotion boards remain the holy of U.S. military holies, more closely held than the secrets of the nation's nuclear arsenal." ${ }^{233}$ The exclusiveness of the three and four-star G/FO ranks, as well as their widened purview of responsibilities, not surprisingly leads to greater and individualized scrutiny of G/FOs from outside the institutional military. Statutory guidance puts strict limits on the number of G/FOs that can serve within each rank at any given time and therefore more senior officers must retire or be removed in order for other officers to advance into the G/FO ranks. The increased scrutiny of Congress and the executive branch, combined with the exclusivity of these higher ranks, presents challenges to any notion that these positions remain completely insulated from external political forces.

The two-star ranks of Major General (Army, Air Force, Marines) or Rear Admiral (Navy) technically denote the highest permanent ranks in the United States military. An officer holds a three or four-star rank only on a temporary basis while they serve in a designated "position of importance" as defined by 10 U.S.C $\$ 601$. Because of the high

\footnotetext{
${ }^{232}$ Roman and Tarr, "Military Professionalism and Policymaking: Is There a Civil-Military Gap at the Top? If So, Does It Matter?," 411. The article references the turbulence created with former Secretary of the Navy, John Lehman attempted to influence the promotions of those officers who worked closely with him. ${ }^{233}$ Ricks, The Generals, 9.
} 
visibility and politically consequential nature of the designated three and four-star positions of importance, the Senate mandates confirmation hearings before a G/FO can assume the respective assignment. Positions of importance include, for example, the Chairman of the JCS, service chiefs, and unified combatant commanders or "COCOMS." ${ }^{234}$ Once an officer departs such a position, however, they revert back to their two-star permanent rank unless assigned to another position of importance. The Senate still holds confirmation hearings even in the case of a lateral move to another position of importance that does not entail a promotion in rank. If Congress deems that an officer has served satisfactorily in their last three or four-star position, and the G/FO held the position for at least three years, they can authorize retirement at the higher rank rather than the permanent two-star rank. ${ }^{235}$

Congress rarely denies three or four-star officers the privilege to retire at their highest rank. A recent example, however, demonstrates that Congress periodically uses this discretionary power as a disciplinary tool. In 2012, for example, Congress denied former four-star Army general and U.S. African Command commander William Ward's request to retire as a four-star following an inspector general's investigation that concluded the general had displayed poor judgment in his use of federal funds for

\footnotetext{
${ }^{234}$ Pronounced "KO-COMS." Until 2002, Combatant Commanders had more commonly been referred to as Commander in Chiefs or "CINCS" (pronounced "sink") of their respective area of responsibilities. With references to civilian control of the military, Secretary of Defense Rumsfeld issued a directive in October 2002 that stated the "CINC" nomenclature should no longer be used in reference to the theater commanders. Rumsfeld explained that the United States had only one such "CINC" and that was the President. See Jim Garamone, "Defense.gov News Article: 'CINC' Is Sunk," October 25, 2002, http://www.defense.gov/news/newsarticle.aspx?id=42568.

${ }^{235}$ Retirement provisions are outlined in 10 U.S.C. $\$ 1370$ and permit some flexibility with regard to time in grade.
} 
private travel and other personal expenses. ${ }^{236}$ Congress allowed Ward to retire as a three-star general, the last rank they deemed he had served in satisfactorily.

Congress's oversight of nominations and promotions for top-ranking officers therefore politicizes the process in many respects. Characteristics of the promotion system at this level therefore invite the question of whether any correlation exists between three or four-star appointments and the partisan activity of senior military officers when they retire. Efforts to uncover any such correlations are wrought with pitfalls, primarily because active-duty officers, for legal, professional and customary reasons, do not normally profess a partisan affiliation or outwardly participate in partisan activities. Furthermore, unlike other presidentially appointed executive positions, nominations to senior military ranks must necessarily come from a small, welldefined pool of individuals. Therefore, even if an administration aimed to nominate only politically sympathetic officers, the relatively small number of general officers eligible limits the number of choices.

The data set described previously provides the means to partially examine the political relationship between G/FO promotions and later RSO service in the executive branch. The party affiliation of the administration that nominated a $\mathrm{G} / \mathrm{FO}$ to three or four-star promotion can be compared with the party affiliation of the administration that later appoints these individuals to civilian positions as RSOs. For this study, the comparison considers only former three and four-star RSOs later appointed to ES level

\footnotetext{
${ }^{236}$ Ernesto Londono, "Accusations Against Generals Cast a Long Shadow over Army," The Washington Post, October 28, 2012, sec. A.
} 
positions. The party of the president that promotes a G/FO to three stars matches the party of the administration that later appoints the G/FO to an ES position twenty-seven out of 39 times in the data set. A stronger correlation exists when considering only retired four-star G/FOs who later served as civilian appointees. A total of 15 individuals in the data set met these latter parameters and all but four served in administrations with a similar partisan match. Only General David Petraeus, Admiral James D. Watkins, General Bruce Carlson, and General Wayne Downing received their fourth star from the opposite party that appointed them to a civilian position.

Prudence dictates a heavy dose of scrutiny on the potential partisan dimension discussed above. First, although the data set covers a quarter of a century, it still only captures four administrations. Also, two of the four administrations spanned eight years. The longevity factor alone could explain the apparent relationship between confirmation as a four-star and a later ES appointment. For instance, if an RSO becomes attractive to an executive administration based on recent expertise, then the civilian appointment would likely follow closely after their military retirement. The eight-year period over two presidential terms could easily encapsulate both the promotions to the two upper military ranks and also the civilian appointment.

The ambassador appointments discussed earlier invite another potential partisan connection. As Table 3.10 highlighted, five of the RSOs appointed as ambassadors retired at the ranks of Lieutenant General (Vice-Admiral) or General (Admiral). Of the five, two of them, Admiral Crowe and Lieutenant General Eikenberry received their last 
star during the administration of the opposite party that appointed them to an ambassadorship; Republican administrations nominated them for their fourth stars, but they received ambassador appointments from Democratic presidents. As mentioned earlier, Admiral Crowe stands as a unique case because although he served as the Chairman, Joint Chiefs of Staff under Reagan and Bush 41, he arguably broke tradition and publically supported Clinton's candidacy and later received a coveted ambassador appointment. Ambassador appointments do not show any obvious partisan relationship with G/FO promotions, but the sample size is too small to warrant much consideration.

The data on retirement dates and executive appointments also revealed that civilian appointments do not typically follow closely after military retirement. For the RSOs included in the study, the time between military retirement and civilian appointment averaged over five years for three and four-star RSOs. Of the 39 civilian appointments in this subgroup, only eight occurred within one-year of retirement and only four RSOs received a civilian appointment from the same president who nominated them to three or four stars. Although tenuous, the empirical findings hint that the possibility of a partisan relationship cannot be completely discounted.

\section{Some Concluding Remarks on the Empirical Data}

The empirical results presented in this chapter suggest that ES level appointments to G/FOs and RSOs have increased over the last 25 years as compared to the earlier Cold War years. Labeling this increase as military colonization, however, may 
reflect a premature characterization. The aggregate increase over the period 1989 to 2012 resulted largely from appointments within one administration. Moreover, the number of G/FOs and RSOs in key positions did not deviate substantially from postWorld War II levels, and like previous administrations, the bulk of the appointments were in the intelligence community. Every modern administration contained a senior military officer (G/FO or RSO) as either the director or deputy of the primary intelligence service. Moreover, with the possible exception of David Petraeus, the RSOs and G/FOs that served in these positions did not fit the heroic warfighter image normally associated with military usurpation. Instead, they resembled little known and reserved figures that emerged from clandestine service like former CIA chief Michael Hayden or DNI James Clapper. ${ }^{237}$ Non-intelligence community appointments Alexander Haig and Colin Powell both possessed a degree of celebrity status, but their reputations were not based on battlefield heroics either. Their significant political experience in non-military positions more likely explains their unique status. Even so, their celebrity status does not diverge from a whole litany of post-World War II politico-military figures: for instance, George Marshall, Maxwell Taylor, Curtis Lemay or William Westmoreland.

In sum, the empirical data does not reveal any obvious patterns of a perilous infiltration of the executive branch by RSOs. Reflecting back to Table 3.2 which gave the

\footnotetext{
${ }^{237}$ Hoover fellow Amy Zegart suggests that military officers make a very poor fit for running intelligence agencies because they tend to favor tactical military operations rather than long-term strategic assessments, clash with ClA culture over the imposition of a rigid hierarchy, and simply just don't appreciate the secrecy rules involved in the intelligence collection. Zegart's broad-brush portrayal of military officers and intelligence overlooks the vast historical record of senior military leaders and RSOs running intelligence agencies. See Amy B. Zegart, "Petraeus a Poor Fit for CIA - Times Union," Timesunion.com, November 24, 2012, http://www.timesunion.com/opinion/article/Petraeus-a-poor-fitfor-CIA-4064042.php.
} 
depiction of the total number of G/FOs that annually retire, RSO presence in the executive branch actually seems surprisingly miniscule. In any case, the empirical findings provide a foundation for the next two chapters which consider how RSOs behaved when they did serve in executive positions and why we may see the levels of participation we do. 


\section{Appendix 3.1: Positions of Interest Bush 41 to Obama}

The table below displays which positions were included in the dataset and how many appointments each president made to each individual position. A "*" in Column 1 indicates that the position is considered a "key" position. Where a cell contains no entry, either the respective president made no appointment to the position or the position did not exist during their administration.

\begin{tabular}{|c|c|c|c|c|c|c|c|}
\hline Key & Dept & $\begin{array}{c}\text { ES } \\
\text { level }\end{array}$ & Job Title & $\begin{array}{c}\text { Bush } \\
41\end{array}$ & Clinton & $\begin{array}{c}\text { Bush } \\
43\end{array}$ & Obama \\
\hline & $\mathrm{AMB}$ & & Ambassadors & 242 & 461 & 524 & 261 \\
\hline$*$ & $\mathrm{ClA}$ & 2 & Director of the $\mathrm{ClA}$ & 1 & 3 & 2 & 2 \\
\hline$*$ & $\mathrm{ClA}$ & 3 & Deputy Director CIA & 1 & 3 & 2 & 1 \\
\hline$*$ & DHS & 1 & Secretary of the DHS & & & 3 & 1 \\
\hline \multirow[t]{11}{*}{$*$} & DHS & 2 & Deputy Secretary of DHS & & & 4 & 1 \\
\hline & DHS & 2 & Under Secretary of DHS - Management & & & 3 & 1 \\
\hline & $\mathrm{DHS}$ & 3 & Under Secretary of DHS - Intelligence \& Analysis & & & & 1 \\
\hline & DHS & 3 & Under Sec of DHS - National Protection \& Programs & & & 1 & 1 \\
\hline & DHS & 4 & Asst Secretary Department of DHS & & & 7 & 5 \\
\hline & DHS & 3 & Under Secretary of DHS for Science \& Technology & & & 2 & 1 \\
\hline & DHS & 3 & Commissioner US Border Patrol & & 2 & 2 & \\
\hline & $\mathrm{DHS}$ & 3 & Director US Citizenship \& Immigration & & & 2 & \\
\hline & DHS & 2 & Director of FEMA & 1 & 2 & 2 & 1 \\
\hline & DHS & 3 & Deputy Director of FEMA & & & 1 & 1 \\
\hline & DNFSB & 3 & Defense Nuclear Facility Safety Board & 7 & 8 & 6 & 5 \\
\hline$*$ & $\mathrm{DNI}$ & 1 & Director of National Intelligence & & & 2 & 2 \\
\hline$*$ & DNI & 2 & Deputy Director of National Intelligence & & & 2 & 2 \\
\hline \multirow[t]{12}{*}{$*$} & $\mathrm{DNI}$ & 2 & Director of Counterterrorism Center & & & 2 & 1 \\
\hline & $\mathrm{DNI}$ & 2 & Director of Counter-proliferation Center & & & 1 & 2 \\
\hline & $\mathrm{DNI}$ & 3 & Chief Info Officer DNI & & & 1 & 2 \\
\hline & DOC & 1 & Secretary of Commerce & 2 & 3 & 2 & 2 \\
\hline & DOC & 2 & Deputy Secretary of Commerce & 2 & 2 & 4 & 3 \\
\hline & DOC & 3 & Und Secretary of Commerce for Economic Affairs & 2 & 2 & 2 & 2 \\
\hline & $\mathrm{DOC}$ & 3 & Und Secretary of Commerce for Export Administration & 1 & 1 & 3 & 1 \\
\hline & DOC & 3 & Und Secretary of Commerce for Intellectual Property & & & 2 & 1 \\
\hline & DOC & 3 & Und Secretary of Commerce for International Trade & 1 & 4 & 2 & 1 \\
\hline & $\mathrm{DOC}$ & 3 & Und Secretary of Commerce for Oceans and Atmosphere & 1 & 1 & 1 & 1 \\
\hline & DOC & 3 & Und Secretary of Commerce for Technology & 1 & 2 & 2 & \\
\hline & DOC & 3 & Und Secretary of Commerce for Travel and Tourism & 2 & 1 & & \\
\hline$*$ & DOD & 1 & Secretary of Defense & 2 & 3 & 2 & 2 \\
\hline \multirow[t]{6}{*}{ * } & DOD & 2 & Deputy Secretary of Defense & 1 & 5 & 2 & 2 \\
\hline & DOD & 2 & Und Sec of Defense (Acquisition, Tech, \& Logistics) & 2 & 3 & 4 & 2 \\
\hline & DOD & 3 & Principle Und Sec of Defense (Acquisition, Tech, \& Logistics) & & & & 1 \\
\hline & DOD & 2 & Secretary of the Air Force & 2 & 4 & 8 & \\
\hline & DOD & 2 & Secretary of the Army & 2 & 4 & 5 & 1 \\
\hline & DOD & 2 & Secretary of the Navy & 4 & 3 & 5 & 1 \\
\hline \multirow[t]{8}{*}{$*$} & DOD & 3 & Under Secretary of Defense for Policy & 1 & 2 & 1 & 3 \\
\hline & DOD & 3 & Under Secretary of Defense - Comptroller & 1 & 2 & 2 & 1 \\
\hline & DOD & 3 & Under Secretary of Defense - Personnel \& Readiness & & 3 & 1 & 2 \\
\hline & DOD & 3 & Under Secretary of Defense - Intelligence & & & 2 & 1 \\
\hline & DOD & 3 & Deputy Chief Management Officer & & & & 1 \\
\hline & DOD & 3 & Under Secretary of the Air Force & 1 & 3 & 2 & 1 \\
\hline & DOD & 3 & Under Secretary of the Navy & 1 & 3 & 2 & 1 \\
\hline & DOD & 3 & Under Secretary of the Army & 1 & 4 & 3 & 1 \\
\hline
\end{tabular}




\begin{tabular}{|c|c|c|c|c|c|c|c|}
\hline Key & Dept & $\begin{array}{c}\text { ES } \\
\text { level }\end{array}$ & Job Title & $\begin{array}{c}\text { Bush } \\
41 \\
\end{array}$ & Clinton & $\begin{array}{c}\text { Bush } \\
43 \\
\end{array}$ & Obama \\
\hline & DOD & 4 & Asst Secretary Air Force - Installations, Environment, Logistics & & 1 & 2 & 1 \\
\hline & DOD & 4 & Asst Secretary Air Force - Manpower \& Reserve Affairs & 1 & 2 & 2 & 1 \\
\hline & DOD & 4 & Asst Secretary AF- Financial Management \& Comptroller & 1 & 1 & 2 & 1 \\
\hline & DOD & 4 & Principal Deputy Under Sec for Personnel \& Readiness & & & 1 & 1 \\
\hline & DOD & 4 & Asst Secretary of Defense for Global Strategic Affairs & & & & 2 \\
\hline & DOD & 4 & Asst Secretary of Defense for Logistics \& Materiel Resources & & & 1 & 1 \\
\hline & DOD & 4 & Asst Secretary Defense for Special Ops \& Low Intensity Conflict & 1 & 2 & 1 & 1 \\
\hline & DOD & 4 & Asst Secretary Defense Asian \& Pacific Security Affairs & & & 1 & 1 \\
\hline & DOD & 4 & General Counsel of the Department of the Army & 1 & 2 & 2 & 1 \\
\hline & DOD & 4 & Principal Deputy Under Sec of Defense (Comptroller) & & & & 1 \\
\hline & DOD & 4 & Director of Operational Energy Plans \& Programs & & & & 1 \\
\hline & DOD & 4 & Asst Secretary of the Army for Installations \& Environment & 1 & 2 & 2 & 1 \\
\hline & DOD & 4 & Principal Deputy Administrator, National Nuclear Sec Admin & & & 2 & 1 \\
\hline & DOD & 4 & Dep Administrator for Def Nuclear Nonproliferation, NNSA & & & 3 & 1 \\
\hline & DOD & 4 & Deputy Under Secretary Defense for Policy & 1 & 3 & 2 & 1 \\
\hline & DOD & 4 & Asst Secretary Defense for International Security Affairs & 2 & 2 & 2 & 1 \\
\hline & DOD & 4 & Asst Secretary Defense for Legislative Affairs & & 2 & 3 & 1 \\
\hline & DOD & 4 & Asst Secretary of the Army for Civil Works & 1 & 2 & 2 & 1 \\
\hline & DOD & 4 & Asst Sec Def for Homeland Defense \& America's Security Affairs & & & 1 & 1 \\
\hline & DOD & 4 & Asst Sec of the Army for Manpower \& Reserve Affairs & 2 & 2 & 2 & 1 \\
\hline & DOD & 4 & General Counsel of the Department of the Air Force & 1 & 3 & 1 & 1 \\
\hline & DOD & 4 & Inspector General DOD & & & 2 & 1 \\
\hline & DOD & 4 & Director of Operation Test \& Evaluation & 1 & 1 & 2 & 1 \\
\hline & DOD & 4 & Director of Defense Research \& Engineering & 2 & 2 & 1 & 1 \\
\hline & DOD & 4 & Asst Secretary of the Navy for Manpower \& Reserve Affairs & 1 & 3 & 1 & 1 \\
\hline & DOD & 4 & Director of Cost Assessment \& Program Eval DOD & & & & 1 \\
\hline & DOD & 4 & Asst Sec of the Navy for Financial Mgt \& Comptroller & 1 & 1 & 3 & 1 \\
\hline & DOD & 4 & Director of the Selective Service & 1 & 1 & 2 & 1 \\
\hline & DOD & 4 & Asst Secretary of Defense for Public Affairs & 1 & 1 & 2 & 1 \\
\hline & DOD & 4 & Asst Sec of the Army For Financial Mgt \& Comptroller & 1 & 1 & 3 & 1 \\
\hline & DOD & 4 & General Counsel of the Navy & 1 & 2 & 2 & 1 \\
\hline & DOD & 4 & Asst Secretary of the Navy for Installations \& Environment & 1 & 1 & 2 & 1 \\
\hline & DOD & 4 & Deputy Administrator for Defense Programs, NNSA & & 1 & 3 & 1 \\
\hline & DOD & 4 & Asst Secretary Defense for Asian \& Pacific Sec Affairs & & & & 1 \\
\hline & DOD & 4 & Asst Secretary of Defense For Reserve Affairs & & 1 & 1 & 1 \\
\hline & DOD & 4 & Asst Secretary of the Army for ALT & & & 1 & 1 \\
\hline & DOD & 4 & Asst Secretary Defense for Health Affairs & 1 & 2 & 2 & 1 \\
\hline & DOD & 4 & Asst Secretary Air Force - Acquisitions & 1 & 3 & 2 & \\
\hline & DOD & 4 & Asst Secretary of Defense for Global Security & & & 1 & \\
\hline & DOD & 4 & Asst Sec Navy for Research, Development, \& Acquisition & 1 & 3 & 3 & \\
\hline & DOD & 4 & Asst to the Sec Defense for Nuclear, Chem \& Bio Def Pgms & & & 2 & 1 \\
\hline & DOD & 4 & Dep Und Sec Defense for Logistics \& Materiel Readiness & & 1 & 1 & \\
\hline & DOD & 4 & Asst Secretary Defense for Networks \& Info Integration & & & 1 & \\
\hline & DOD & 4 & Dep Und Sec Defense for Acquisition \& Technology & 2 & 2 & 2 & \\
\hline & DOD & 4 & Asst Secretary Defense for Force Management Policy & 1 & 2 & 1 & \\
\hline & DOD & 4 & General Counsel Department of Defense & 2 & 4 & 1 & \\
\hline & DOD & 4 & Asst Sec Defense for International Security Policy & 1 & & 1 & \\
\hline & DOD & 4 & Asst Sec Def for Command Control Communications \& Intel & 1 & 2 & 1 & \\
\hline & DOD & 4 & Asst Secretary Air Force for Space & 1 & 1 & & \\
\hline & DOD & 4 & Asst Sec of the Army for Research, Development \& Acquisition & 1 & 2 & & \\
\hline & DOD & 4 & Asst Sec Def for Nuclear Security \& Counterproliferation & & 1 & & \\
\hline & DOD & 4 & Asst Secretary Defense for Strategy \& Resources & & 1 & & \\
\hline & DOD & 4 & Asst Secretary Defense for Atomic Energy & & 1 & & \\
\hline & DOD & 4 & Asst Secretary Defense for Regional Security Affairs & & 1 & & \\
\hline & DOD & 4 & Asst Secretary Defense for Personnel \& Readiness & & 1 & & \\
\hline & DOD & 4 & Asst Secretary Defense for Policy \& Plans & & 1 & & \\
\hline & DOD & 4 & Asst Secretary Defense for Economic Security & & 1 & & \\
\hline & DOD & 4 & Asst Secretary of Defense for Production \& Logistics & 1 & & & \\
\hline & DOE & 1 & Secretary of Energy & 1 & 3 & 2 & 1 \\
\hline & $\mathrm{DOE}$ & 2 & Deputy Secretary of Energy & 1 & 4 & 3 & 1 \\
\hline
\end{tabular}




\begin{tabular}{|c|c|c|c|c|c|c|c|}
\hline Key & Dept & $\begin{array}{c}\text { ES } \\
\text { level }\end{array}$ & Job Title & $\begin{array}{c}\text { Bush } \\
41\end{array}$ & Clinton & $\begin{array}{c}\text { Bush } \\
43\end{array}$ & Obama \\
\hline & $\mathrm{DOE}$ & 3 & Under Secretary of Energy & 1 & 3 & 3 & 2 \\
\hline & $\mathrm{DOE}$ & 4 & Und Sec for Nuclear Sec \& Administrator, Nat'I Nuke Sec Admin & & 1 & 2 & \\
\hline & $\mathrm{DOI}$ & 1 & Secretary of the Interior & 1 & 1 & 2 & 1 \\
\hline & $\mathrm{DOI}$ & 2 & Deputy Secretary of the Interior & & 2 & 2 & 1 \\
\hline & $\mathrm{DOI}$ & 3 & Under Secretary of the Interior & 1 & & & \\
\hline * & DOJ & 1 & Attorney General & 1 & 1 & 3 & 1 \\
\hline \multirow[t]{7}{*}{$*$} & DOJ & 2 & Deputy Attorney General & 3 & 3 & 4 & 2 \\
\hline & DOJ & 3 & Solicitor General & 1 & 2 & 3 & 2 \\
\hline & DOJ & 3 & Associate Attorney General & 1 & 4 & 3 & 2 \\
\hline & DOJ & 3 & Administrator DEA & 1 & 2 & 2 & 1 \\
\hline & DOJ & $4 / 5$ & Deputy Administrator DEA & 1 & 2 & 2 & 1 \\
\hline & DOJ & 3 & Director, Alcohol Tobacco, Firearms, Ex & & 2 & 3 & 3 \\
\hline & DOJ & 4 & Director, US Marshall Service & 2 & 2 & 2 & 1 \\
\hline \multirow[t]{3}{*}{$*$} & DOJ & 2 & Director of the FBI & & 1 & 1 & \\
\hline & $\mathrm{DOL}$ & 2 & Secretary of Labor & 2 & 1 & 1 & 1 \\
\hline & DOL & 2 & Deputy Secretary of Labor & 2 & 3 & 2 & 2 \\
\hline$*$ & DOS & 1 & Secretary of State & 2 & 2 & 2 & 1 \\
\hline$*$ & DOS & 2 & Deputy Secretary of State & 2 & 2 & 3 & 2 \\
\hline \multirow[t]{42}{*}{$*$} & DOS & 3 & Under Secretary of State for Political Affairs & 2 & 2 & 3 & 1 \\
\hline & DOS & 3 & Under Secretary of State for Economic, Energy, \& Agric Affairs & 2 & 3 & 2 & 1 \\
\hline & DOS & 3 & Under Secretary of State for Management & 2 & 3 & 3 & 2 \\
\hline & DOS & 4 & General Counsel Department of State & 2 & & & \\
\hline & DOS & 4 & Asst Secretary of State for Inter-American Affairs & 1 & 2 & & \\
\hline & DOS & 4 & Asst Sec State for Oceans, Int'I Environmental \& Scientific Affairs & 1 & 1 & 2 & 1 \\
\hline & DOS & 4 & Asst Secretary of State for Int'I Organizations & 1 & & 2 & \\
\hline & DOS & 4 & Asst Secretary of State for Politico-Military Affairs & 2 & 3 & 2 & 1 \\
\hline & DOS & 4 & Asst Secretary of State for Administration & 1 & 1 & 2 & 1 \\
\hline & DOS & 4 & U.S. Coordinator for Refugee Affairs & 1 & & & \\
\hline & DOS & 4 & Asst Secretary of State for Int'I Narcotics Matters & 1 & 1 & 1 & \\
\hline & DOS & 4 & Asst Secretary of State for Intel \& Research & 1 & 2 & 3 & 1 \\
\hline & DOS & 4 & Asst Secretary of State for Legislative Affairs & 1 & 2 & 3 & 2 \\
\hline & DOS & 4 & Asst Secretary of State for East Asia \& Pacific Affairs & 2 & 2 & 2 & 1 \\
\hline & DOS & 4 & Asst Secretary of State for Consular Affairs & 1 & 1 & 2 & \\
\hline & DOS & 4 & Asst Secretary of State for Public Affairs & 1 & 3 & 1 & 2 \\
\hline & DOS & 4 & Chief of Protocol State Department & 1 & & 2 & \\
\hline & DOS & 4 & Asst Secretary of State for Diplomatic Security & 2 & 1 & 3 & \\
\hline & DOS & 4 & Chief Finance Officer Department of State & 1 & 3 & 1 & \\
\hline & DOS & 4 & Asst Secretary of State for Near Eastern \& South Asian Affairs & 2 & & & \\
\hline & DOS & 4 & Asst Secretary of State for Human Rights \& Humanitarian Affairs & 1 & 1 & & \\
\hline & DOS & 4 & Asst Secretary of State for European \& Canadian Affairs & 1 & 4 & & \\
\hline & DOS & 3 & Under Secretary of State for Arms Control \& Intn'I Sec & & 2 & 3 & 2 \\
\hline & DOS & 3 & Under Secretary of State for Public Diplomacy & & 1 & 4 & 2 \\
\hline & DOS & 3 & Under Secretary of State Democracy \& Global Affairs & & 3 & 1 & 1 \\
\hline & DOS & 4 & Department of State Inspector General & & 1 & 2 & \\
\hline & DOS & 3 & Und Secretary of State for International Security Affairs & & 1 & & \\
\hline & DOS & 4 & Asst Secretary of State for Int'I Organization Affairs & & 3 & 1 & 1 \\
\hline & DOS & 4 & Asst Secretary of State for African Affairs & & 2 & 3 & 1 \\
\hline & DOS & 4 & Asst Secretary of State for Population, Refugees \& Migration & & 2 & 2 & 2 \\
\hline & DOS & 4 & Asst Secretary of State for Near East Asia Affairs & & 3 & 1 & 1 \\
\hline & DOS & 4 & Asst Secretary of State for South Asian Affairs & & 2 & & \\
\hline & DOS & 4 & Ambassador at Large & & 4 & 4 & 2 \\
\hline & DOS & 4 & Asst Secretary of State for Economic \& Business Affairs & & 3 & 1 & 1 \\
\hline & DOS & 4 & Inspector General DOS & & 1 & 1 & \\
\hline & DOS & 4 & Asst Sec of State for Int'I Narcotics \& Law Enforcement Affairs & & 1 & 1 & 1 \\
\hline & DOS & 4 & Asst Secretary of State for Education \& Cultural Affairs & & 1 & 3 & 1 \\
\hline & DOS & 4 & Asst Secretary of State for Proliferation & & 1 & 1 & \\
\hline & DOS & 4 & Asst Secretary of State for Verification \& Compliance & & 1 & 1 & 1 \\
\hline & DOS & 4 & Asst Secretary of State for Resource Management & & & 2 & \\
\hline & DOS & 4 & Special Rep of Secretary State for HIV/AIDS & & & 1 & \\
\hline & DOS & 4 & Asst Sec of State for Democracy, Human Rights, and Labor & & & 3 & 1 \\
\hline
\end{tabular}




\begin{tabular}{|c|c|c|c|c|c|c|c|}
\hline Key & Dept & $\begin{array}{c}\text { ES } \\
\text { level }\end{array}$ & Job Title & $\begin{array}{c}\text { Bush } \\
41\end{array}$ & Clinton & $\begin{array}{c}\text { Bush } \\
43\end{array}$ & Obama \\
\hline & DOS & 4 & Asst Secretary of State for European Affairs & & & 2 & \\
\hline & DOS & 4 & Asst Secretary of State for Western Hemisphere Affairs & & & 2 & 2 \\
\hline & DOS & 4 & Asst Sec of State for International Security \& Non-Proliferation & & & 1 & 1 \\
\hline & DOS & 4 & Asst Secretary of State for European \& Eurasian Affairs & & & & 1 \\
\hline & DOS & 4 & Asst Sec of State for Conflict and Stabilization Operations & & & & 1 \\
\hline$*$ & DOT & 1 & Secretary of Transportation & 2 & 2 & 2 & 1 \\
\hline \multirow{41}{*}{$*$} & DOT & 2 & Deputy Secretary of Transportation & 3 & 1 & 4 & 1 \\
\hline & DOT & 2 & Under Secretary of Transportation for Policy & & & 1 & 2 \\
\hline & DOT & 2 & Administrator Federal Aviation Administration & 2 & 2 & 1 & 2 \\
\hline & DOT & 2 & Administrator Federal Highway Administration & 1 & 2 & 3 & 1 \\
\hline & DOT & 3 & Administrator Federal Motor Carrier Safety Administration & & & 3 & 1 \\
\hline & DOT & 3 & Administrator, Pipeline and Hazardous Materials Safety Admin & & & 2 & 1 \\
\hline & DOT & 3 & Chairman Surface Transportation Board & & 1 & 3 & 1 \\
\hline & DOT & 3 & Administrator Maritime Administration & 1 & 2 & 3 & 1 \\
\hline & DOT & 3 & Administrator, Research \& Innovative Tech Administration & & & 2 & 1 \\
\hline & DOT & 3 & Administrator of the Nat'I Highway Traffic Safety Admin & 2 & 2 & 2 & 1 \\
\hline & DOT & 3 & Administrator Federal Railroad Administration & 1 & 1 & 2 & 1 \\
\hline & DOT & 3 & Federal Transit Administrator & 1 & 2 & 2 & 1 \\
\hline & DOT & 4 & Assistant Secretary of Trans & 6 & 8 & 12 & 4 \\
\hline & DOT & 4 & Deputy Administrator FAA & 1 & 1 & 1 & 1 \\
\hline & DOT & 4 & General Counsel Department of Transportation & 3 & 2 & 2 & 1 \\
\hline & DOT & 2 & Under Secretary of Transportation for Security & & & 2 & \\
\hline & DOT & 5 & Inspector General Department of Transportation & 1 & & 1 & \\
\hline & DOT & 4 & Admin of St Lawrence Seaway & 1 & 1 & 1 & \\
\hline & DOT & 5 & Associate Deputy Secretary of Transportation & 1 & 2 & & \\
\hline & EDU & 1 & Secretary of Education & 1 & 1 & 2 & 1 \\
\hline & EDU & 2 & Deputy Secretary of Education & 1 & 2 & 3 & 1 \\
\hline & EDU & 2 & Director Institute of Education Sciences & & & 1 & 1 \\
\hline & EDU & 3 & Under Secretary of Education & 1 & 1 & 3 & 1 \\
\hline & EDU & 3 & Asst Secretary of Ed for Planning, Eval, \& Policy Development & & & 2 & 1 \\
\hline & EPA & 2 & Administrator EPA & 1 & 1 & 3 & 1 \\
\hline & EPA & 3 & Deputy Administrator EPA & 1 & 3 & 3 & 1 \\
\hline & FCC & 3 & Chairman, Federal Communications Commission & 1 & 1 & 3 & 1 \\
\hline & FEMA & 3 & Director FEMA & 1 & 1 & 1 & \\
\hline & FERC & 3 & Chairman Federal Energy Regulatory Commission & 1 & 3 & 4 & \\
\hline & FMC & 3 & Chairman Federal Maritime Commission & 3 & 1 & 1 & 1 \\
\hline & GSA & 3 & Administrator General Services Administration & 1 & 2 & 2 & 1 \\
\hline & $\mathrm{HHS}$ & 1 & Secretary of Health and Human Services & 1 & 1 & 2 & 1 \\
\hline & HHS & 2 & Deputy Secretary of Health and Human Services & 1 & 2 & 3 & 1 \\
\hline & $\mathrm{HHS}$ & 3 & Under Secretary of Health and Human Services & 1 & & & \\
\hline & HUD & 1 & Secretary of HUD & 1 & 2 & 3 & 1 \\
\hline & HUD & 2 & Deputy Secretary of HUD & & 3 & 1 & 1 \\
\hline & HUD & 3 & Under Secretary of HUD & 1 & & & \\
\hline & NASA & 2 & Administrator NASA & 2 & & 2 & 1 \\
\hline & NASA & 3 & Deputy Administrator & 1 & & 2 & 1 \\
\hline & NRC & 2 & Chairman Nuclear Regulatory Commission (\& Commissioner) & 1 & 3 & 4 & 1 \\
\hline & NRC & 3 & Commissioner Nuclear Regulatory Commission & 3 & 2 & 2 & 4 \\
\hline$*$ & NSA & PA & Asst to the President for Nat'I Sec Affairs (Nat'I Sec Advisor) & 1 & 2 & 2 & 2 \\
\hline \multirow[t]{5}{*}{$*$} & NSA & PA & Deputy Nat'I Sec Advisor & 1 & 1 & 3 & 2 \\
\hline & NSF & 2 & Director National Science Foundation & 1 & 2 & 1 & 1 \\
\hline & NSF & 3 & Deputy Director National Science Foundation & 1 & 2 & 1 & 1 \\
\hline & NTSB & 3 & Chairman National Transportation Safety Board & 2 & 1 & 3 & 1 \\
\hline & OGE & 3 & Director Office of Government Ethics & 1 & 1 & 1 & 1 \\
\hline \multirow[t]{7}{*}{ * } & $\mathrm{OMB}$ & 1 & Director Office of Management and Budget & 1 & 5 & 3 & 2 \\
\hline & $\mathrm{OMB}$ & 2 & Deputy Director OMB & 2 & 6 & 5 & 2 \\
\hline & OMB & 2 & Deputy Director for Management OMB & & 1 & 1 & 1 \\
\hline & OMB & 3 & Controller, Federal Financial Management OMB & 1 & 3 & 3 & 1 \\
\hline & $\mathrm{OMB}$ & 3 & Administrator, Office of Information and Regulatory Affairs & & 2 & 1 & 1 \\
\hline & OMB & 3 & Administrator, Office of Federal Procurement Policy & 1 & 2 & 3 & 2 \\
\hline & ONDCP & 1 & Director, Office of National Drug Control Policy & 2 & 2 & 1 & 1 \\
\hline
\end{tabular}




\begin{tabular}{|c|c|c|c|c|c|c|c|}
\hline Key & Dept & $\begin{array}{c}\text { ES } \\
\text { level }\end{array}$ & Job Title & $\begin{array}{c}\text { Bush } \\
41\end{array}$ & Clinton & $\begin{array}{c}\text { Bush } \\
43\end{array}$ & Obama \\
\hline & ONDCP & 2 & Deputy Director Office of National Drug Control Policy & & & 2 & 2 \\
\hline & ONDCP & 3 & Deputy Director for Demand Reduction NDCP & & & & \\
\hline & ONDCP & 3 & Deputy Director for State, Local, \& Tribal Affairs NDCP & & & 1 & 1 \\
\hline & ONDCP & 3 & Deputy Director for Supply Reduction & 2 & 1 & & 1 \\
\hline & OPM & 2 & Director Officer of Personnel Management & 1 & 2 & 2 & 1 \\
\hline & OPM & 3 & Deputy Director OPM & 1 & 2 & 2 & 1 \\
\hline & OST & 2 & Director, Office of Science and Technology & 1 & 2 & 1 & 1 \\
\hline$*$ & TREAS & 1 & Secretary of the Treasury & & 3 & 3 & 1 \\
\hline \multirow[t]{30}{*}{ * } & TREAS & 2 & Deputy Secretary of the Treasury & 1 & 4 & 3 & 2 \\
\hline & TREAS & 3 & Und Secretary of the Treasury & 3 & 6 & 5 & 3 \\
\hline & TREAS & 3 & Comptroller of the Currency & & 2 & 1 & 1 \\
\hline & TREAS & 3 & Commissioner of the IRS & 1 & 3 & 2 & \\
\hline & TREAS & 3 & Director, Office of Thrift Supervision & 1 & 1 & 2 & \\
\hline & TREAS & 4 & Asst Secretary of Treasury for Intel \& Analysis & & & 1 & 1 \\
\hline & USAID & 2 & Administrator USAID & 1 & 2 & 3 & 1 \\
\hline & USAID & 3 & Deputy Administrator USAID & 1 & 2 & 1 & 1 \\
\hline & USDA & 1 & Secretary of Agriculture & 2 & 2 & 3 & 1 \\
\hline & USDA & 2 & Deputy Secretary of Agriculture & 2 & 1 & 1 & 1 \\
\hline & USDA & 3 & Und Secretary of Agriculture & 1 & 8 & 12 & 9 \\
\hline & USTR & 1 & United States Trade Representative & 1 & 2 & 3 & 1 \\
\hline & VA & 1 & Secretary of Veterans Affairs & 1 & 2 & 3 & 1 \\
\hline & VA & 2 & Deputy Secretary of Veterans Affairs & 1 & 1 & 2 & 1 \\
\hline & VA & 3 & Under Secretary for Health & 1 & 2 & 3 & 1 \\
\hline & VA & 3 & Under Secretary for Memorial Affairs & & 1 & 3 & 1 \\
\hline & VA & 3 & Under Secretary for Benefits & 1 & 2 & 3 & 1 \\
\hline & VA & 4 & Chairman, Board of Veterans Appeals & 1 & 1 & 1 & 1 \\
\hline & VA & 4 & General Counsel Deputy of VA & 2 & 2 & 2 & 1 \\
\hline & VA & 4 & Asst Sec of VA (Public and Intergovernmental Affairs) & & 2 & 3 & 2 \\
\hline & VA & 4 & Asst Secretary of VA (Human Resources) & 1 & 1 & 2 & 1 \\
\hline & VA & 4 & Asst Sec of VA (Ops, Preparedness, Security \& Law Enforcement) & & & 1 & 1 \\
\hline & VA & 4 & Asst Secretary of VA (Information \& Tech) & 1 & & 3 & 1 \\
\hline & VA & 4 & Asst Secretary of VA (Policy and Planning) & 1 & 2 & 3 & 1 \\
\hline & VA & 4 & Asst Secretary of VA (Congressional \& Leg Affairs) & 2 & 1 & 4 & 1 \\
\hline & VA & 4 & Asst Secretary of VA (Management) & & 1 & 2 & \\
\hline & VA & 4 & Inspector General VA & 1 & 1 & 1 & \\
\hline & VA & 4 & Asst Secretary of VA (Finance and Info Resource Management) & 1 & 1 & & \\
\hline & VA & 4 & Asst Secretary of VA (Veterans Liaison \& Program Coordination) & 1 & & & \\
\hline & VA & 4 & Asst Secretary of VA (Acquisition \& Facilities) & 1 & & & \\
\hline$*$ & WH & PA & Assistant to the President for National Security Affairs & 1 & 2 & 2 & 2 \\
\hline \multirow[t]{2}{*}{$*$} & WH & PA & Deputy Assistant to the President for National Security Affairs & 1 & 2 & 5 & 3 \\
\hline & WH & PA & Assistant to the President for Homeland Security & & & 2 & 1 \\
\hline$*$ & $\mathrm{WH}$ & $\mathrm{PA}$ & Chief of Staff & 3 & 4 & 2 & 3 \\
\hline
\end{tabular}




\section{Appendix 3.2: G/FOs \& RSOs in Positions of Interest Bush 41 to Obama}

\begin{tabular}{|c|c|c|c|c|c|c|}
\hline Name & Pres & Position Title & ES Level & Service & Rank & $\begin{array}{l}\text { Retired/ } \\
\text { Active }\end{array}$ \\
\hline Brent Skowcroft & Bush 41 & Nat'I Sec Advisor & PA & USAF & Lt Gen & $R \& A$ \\
\hline James A. Carey & Bush 41 & Chairman, Federal Maritime Commission & 3 & USNR & Rear Admiral & $\mathrm{R}$ \\
\hline James D. Watkins & Bush 41 & Secretary of Energy & 1 & USN & Admiral & $\mathrm{R}$ \\
\hline James B. Busey & Bush 41 & Administrator, FAA & 2 (DOT) & USN & Admiral & $\mathrm{R}$ \\
\hline Richard H. Truly & Bush 41 & Administrator, NASA & 2 & USN & Vice Admiral & $\mathrm{R}$ \\
\hline Jerry Ralph Curry & Bush 41 & Administrator, Nat'I Highway Traffic Safety Admin & 3 & USA & Major General & $\mathrm{R}$ \\
\hline Jerome G. Cooper & Bush 41 & $\begin{array}{l}\text { Asst Secretary Air Force: Manpower \& Reserve } \\
\text { Affairs }\end{array}$ & 4 (DOD) & USMCR & Major General & $\mathrm{R}$ \\
\hline Enrique Mendez, MD & Bush 41 & Asst Secretary Defense for Health Affairs & 4 (VA) & USA & Major General & $\mathrm{R}$ \\
\hline D’Wayne Gray & Bush 41 & Under Secretary for Benefits & $3(\mathrm{VA})$ & USMC & Lt General & $\mathrm{R}$ \\
\hline James W. Holsinger & Bush 41 & Under Secretary for Health & $3(\mathrm{VA})$ & USAR & Major General & $\mathrm{R}$ \\
\hline Jonathan Howe & Bush 41 & Deputy Nat'I Sec Advisor & PA & USN & Admiral & A \\
\hline James B. Busey & Bush 41 & Deputy Secretary of Transportation & 2 (DOT) & USN & Admiral & $\mathrm{R}$ \\
\hline William O. Studeman & Bush 41 & Deputy Director CIA & PA & USN & Admiral & $A$ \\
\hline Thomas C. Richards & Bush 41 & Administrator, FAA & 2 (DOT) & USAF & General & $\mathrm{R}$ \\
\hline Vernon A. Walters & Bush 41 & Ambassador, Federal Republic of Germany & FS (DOS) & USA & Lt General & $\mathrm{R}$ \\
\hline Robert M. Kimmitt & Bush 41 & Ambassador, Federal Republic of Germany & FS (DOS) & USAR & Major General & $\mathrm{R}$ \\
\hline James G. Randolph & Bush 41 & Asst Secretary of Energy & 4 (DOE) & USAF & Major General & $\mathrm{R}$ \\
\hline Albert J. Herberger & Clinton & Administrator, Federal Maritime Administration & 3 & USN & Vice Admiral & $\mathrm{R}$ \\
\hline Emmett Paige & Clinton & $\begin{array}{l}\text { Asst Sec Defense for Command, Control, Comm, \& } \\
\text { Intel }\end{array}$ & 4 (DOD) & USA & Lt General & $\mathrm{R}$ \\
\hline John W. Douglass & Clinton & $\begin{array}{l}\text { Asst Sec Navy for Research, Development \& } \\
\text { Acquisition }\end{array}$ & 4 (DOD) & USAF & Brig General & $\mathrm{R}$ \\
\hline Barry R. McCaffrey & Clinton & Director, Office of National Drug Control Policy & PA & USA & General & $R$ \\
\hline Kenneth R. Wykle & Clinton & Administrator, Federal Highway Administration & 2 & USA & Lt General & $\mathrm{R}$ \\
\hline John A. Gordon & Clinton & Deputy Director, CIA & 3 & USAF & General & $A$ \\
\hline David R. Oliver & Clinton & $\begin{array}{l}\text { Deputy Under Secretary of Def for Acquisition \& } \\
\text { Tech }\end{array}$ & 4 (DOD) & USN & Rear Admiral & $\mathrm{R}$ \\
\hline John A. Gordon & Clinton & $\begin{array}{l}\text { Administrator for Nat'I Nuclear Security } \\
\text { Administration }\end{array}$ & 4 & USAF & General & $\mathrm{R}$ \\
\hline Jerome G. Cooper & Clinton & Ambassador to Jamaica & FS (DOS) & USMCR & Major General & $\mathrm{R}$ \\
\hline William J. Crowe & Clinton & Ambassador to United Kingdom & FS (DOS) & USN & Admiral & $\mathrm{R}$ \\
\hline Gregory G. Govan & Clinton & Chief, U.S. Delegate to the Joint Consultative Group & FS (DOS) & USA & Brig General & $\mathrm{R}$ \\
\hline Joseph W. Prueher & Clinton & Ambassador to China & FS (DOS) & USN & Admiral & $\mathrm{R}$ \\
\hline Archer L. Durham & Clinton & Asst Secretary of Energy & 4 (DOE) & USAF & Major General & $\mathrm{R}$ \\
\hline Ronald M. Sega & Bush 43 & Under Secretary of the Air Force & 3 (DOD) & USAFR & Major General & $\mathrm{R}$ \\
\hline James M. Loy & Bush 43 & Secretary, Department of Homeland Security & 1 (DHS) & USCG & Admiral & $\mathrm{R}$ \\
\hline James M. Loy & Bush 43 & Dep Secretary, Department of Homeland Security & 2 (DHS) & USCG & Admiral & $\mathrm{R}$ \\
\hline Jay M. Cohen & Bush 43 & $\begin{array}{l}\text { Under Sec Dept of Homeland Security, Science \& } \\
\text { Tech }\end{array}$ & 3 (DHS) & USN & Rear Admiral & $\mathrm{R}$ \\
\hline Colin Powell & Bush 43 & Secretary of State & 1 (DOS) & USA & General & $\mathrm{R}$ \\
\hline Thomas E. White & Bush 43 & Secretary of the Army & 2 (DOD) & USA & Brig General & $\mathrm{R}$ \\
\hline William A. Navas & Bush 43 & Asst Sec of the Navy for Manpower \& Reserve Affairs & 4 (DOD) & USA & Major General & $\mathrm{R}$ \\
\hline Ronald M. Sega & Bush 43 & Director of Defense Research and Engineering & 4 (DOD) & USAF & Major General & $\mathrm{R}$ \\
\hline H.T. Johnson & Bush 43 & $\begin{array}{l}\text { Asst Sec of the Navy for Installations and } \\
\text { Environment }\end{array}$ & 4 (DOD) & USAF & General & $\mathrm{R}$ \\
\hline Claude M. Bolton & Bush 43 & Asst Sec of the Army for Acquisition, Tech \& Logistics & 4 (DOD) & USAF & Major General & $\mathrm{R}$ \\
\hline Daniel L. Cooper & Bush 43 & Under Secretary for Benefits & 3 (VA) & USN & Vice Admiral & $\mathrm{R}$ \\
\hline Thomas F. Hall & Bush 43 & Asst Secretary Defense for Reserve Affairs & 4 (DOD) & USN & Admiral & $\mathrm{R}$ \\
\hline James M. Loy & Bush 43 & Under Secretary of Transportation for Security & 2 (DOT) & USCG & Admiral & $\mathrm{R}$ \\
\hline Francis X. Taylor & Bush 43 & Asst Secretary of State for Diplomatic Security & 4 (DOS) & USAF & Brig General & $\mathrm{R}$ \\
\hline John W. Nicholson & Bush 43 & Under Secretary for Memorial Affairs & 3 (VA) & USA & Brig General & $\mathrm{R}$ \\
\hline
\end{tabular}




\begin{tabular}{|c|c|c|c|c|c|c|}
\hline Name & Pres & Position Title & ES Level & Service & Rank & $\begin{array}{l}\text { Retired/ } \\
\text { Active }\end{array}$ \\
\hline $\begin{array}{l}\text { John J. } \\
\text { Grossenbacher }\end{array}$ & Bush 43 & Chairman, Nuclear Regulatory Commission & 2 & USN & Vice Admiral & $\mathrm{R}$ \\
\hline David M. Stone & Bush 43 & Asst Secretary, Department of Homeland Security & 4 (DHS) & USN & Admiral & $\mathrm{R}$ \\
\hline Albert H. Konetzni & Bush 43 & Commissioner, Nuclear Regulatory Commission & 3 & USN & Vice Admiral & $\mathrm{R}$ \\
\hline Michael V. Hayden & Bush 43 & Deputy Director National Intelligence & 2 (DHS) & USAF & Lt General & A \\
\hline Albert M. Calland & Bush 43 & Deputy Director, $\mathrm{CIA}$ & 3 & USN & Vice Admiral & $\mathrm{A}$ \\
\hline John S. Redd & Bush 43 & Director, Counter Terrorism Center & 2 (DNI) & USN & Vice Admiral & $\mathrm{R}$ \\
\hline Dale W. Meyerrose & Bush 43 & Chief Info Officer, Office of Director Nat'I Intelligence & 4 (DNI) & USAF & Major General & $\mathrm{R}$ \\
\hline Richard Capka & Bush 43 & Administrator, Federal Highway Administration & 2 (DOT) & USA & Brig General & $\mathrm{R}$ \\
\hline Thomas J. Barrett & Bush 43 & Administrator, Pipeline \& HazMat Safety Admin & 3 (DOT) & USCG & Admiral & $\mathrm{R}$ \\
\hline Michael V. Hayden & Bush 43 & Director CIA & 2 & USAF & General & $R \& A$ \\
\hline Daniel L. Cooper & Bush 43 & Under Secretary for Benefits & $3(\mathrm{VA})$ & USN & Vice Admiral & $\mathrm{R}$ \\
\hline Mark V. Rosenker & Bush 43 & Chairman, National Transportation Safety Board & 3 (NTSB) & USAFR & Major General & $\mathrm{R}$ \\
\hline Calvin L. Scovel & Bush 43 & Inspector General, Department of Transportation & 4 (DOT) & USMC & Brig General & $\mathrm{R}$ \\
\hline John M. McConnell & Bush 43 & Director National Intelligence & 1 (DNI) & USN & Vice Admiral & $\mathrm{R}$ \\
\hline James R. Clapper & Bush 43 & Under Secretary of Defense for Intelligence & 3 (DOD) & USAF & Lt General & $\mathrm{R}$ \\
\hline Claude K. Kicklighter & Bush 43 & Inspector General, Department of Defense & 4 (DOD) & USA & Lt General & $\mathrm{R}$ \\
\hline Michael J. Kussman & Bush 43 & Under Secretary for Health & 3 (VA) & USA & Brig General & $\mathrm{R}$ \\
\hline Dell L. Dailey & Bush 43 & $\begin{array}{l}\text { Coordinator, Counter-Terrorism, Ambassador at } \\
\text { Large }\end{array}$ & 4 (DOS) & USA & Lt General & $\mathrm{R}$ \\
\hline Thomas J. Barrett & Bush 43 & Deputy Secretary of Transportation & 2 (DOT) & USCG & Admiral & $\mathrm{R}$ \\
\hline Robert L. Smolen & Bush 43 & $\begin{array}{l}\text { Dep Administrator for Defense Pgms, Nuclear Sec } \\
\text { Admin }\end{array}$ & 4 (DOD) & USAF & Major General & $R$ \\
\hline James B. Peake & Bush 43 & Secretary of Veterans Affairs & $1(\mathrm{VA})$ & USA & Lt General & $R$ \\
\hline Mark Kimmitt & Bush 43 & Asst Secretary of State for Politico-Military Affairs & 4 (DOS) & USA & Brig General & $\mathrm{R}$ \\
\hline Patrick W. Dunne & Bush 43 & Under Secretary for Benefits & $3(\mathrm{VA})$ & USN & Admiral & $R$ \\
\hline Claude M. Kicklighter & Bush 43 & $\begin{array}{l}\text { Asst Secretary of Veterans Affairs (Policy and } \\
\text { Planning) }\end{array}$ & 4 (VA) & USA & Lt General & $\mathrm{R}$ \\
\hline John A. Gauss & Bush 43 & Asst Secretary of Veterans Affairs (Info and Tech) & 4 (VA) & USN & Rear Admiral & $\mathrm{R}$ \\
\hline Patrick W. Dunne & Bush 43 & $\begin{array}{l}\text { Asst Secretary of Veterans Affairs (Policy and } \\
\text { Planning) }\end{array}$ & 4 (VA) & USN & Admiral & $\mathrm{R}$ \\
\hline Robert T. Howard & Bush 43 & Asst Secretary of Veterans Affairs (Info and Tech) & 4 (VA) & USA & Major General & $\mathrm{R}$ \\
\hline Francis X. Taylor & Bush 43 & $\begin{array}{l}\text { Coordinator for Counter-Terror, Ambassador at } \\
\text { Large }\end{array}$ & FS (DOS) & USAF & Brig General & $\mathrm{R}$ \\
\hline $\begin{array}{l}\text { Conrad } \\
\text { Lautenbacher }\end{array}$ & Bush 43 & Under Sec of Commerce for Oceans and Atmosphere & 3 (DOC) & USN & Vice Admiral & $\mathrm{R}$ \\
\hline Robert M. Kimmitt & Bush 43 & Deputy Secretary of the Treasury & 2 (Treas) & USAR & Major General & $\mathrm{R}$ \\
\hline Douglas Lute & Bush 43 & $\begin{array}{l}\text { Deputy Asst to Pres for Nat'I Security Affairs- } \\
\text { Iraq/Afghan }\end{array}$ & PA & USA & Lt General & A \\
\hline Wayne Downing & Bush 43 & Deputy Asst to President for Nat'I Security Affairs & $\mathrm{PA}$ & USA & General & $\mathrm{R}$ \\
\hline Eric K. Shinseki & Obama & Secretary of Veterans Affairs & $1(\mathrm{VA})$ & USA & General & $\mathrm{R}$ \\
\hline Dennis Blair & Obama & Director of National Intelligence & 1 (DNI) & USN & Admiral & $\mathrm{R}$ \\
\hline James Jones & Obama & National Security Advisor & PA & USMC & General & $\mathrm{R}$ \\
\hline Wallace C. Gregson & Obama & $\begin{array}{l}\text { Asst Sec of Defense for Asian \& Pacific Security } \\
\text { Affairs }\end{array}$ & 4 (DOD) & USMC & Lt General & $\mathrm{R}$ \\
\hline Dennis M. McCarthy & Obama & Asst Secretary of Defense for Reserve Affairs & 4 (DOD) & USMCR & Lt General & $\mathrm{R}$ \\
\hline Charles F. Bolden & Obama & Administrator, NASA & 2 & USMC & Major General & $\mathrm{R}$ \\
\hline Clifford L. Stanley & Obama & Under Sec of Defense for Personnel and Readiness & 3 (DOD) & USMC & Major General & $\mathrm{R}$ \\
\hline Malcolm Ross O’Neill & Obama & $\begin{array}{l}\text { Asst Sec of the Army for Acquisition, Logistics, and } \\
\text { Tech }\end{array}$ & 4 (DOD) & USA & Lt General & $\mathrm{R}$ \\
\hline Jonathan Woodson, MD & Obama & Asst Secretary of Defense for Health Affairs & 4 (DOD) & USAR & Brig General & $\mathrm{R}$ \\
\hline James R. Clapper & Obama & Director of National Intelligence & 1 (DNI) & USAF & Lt General & $\mathrm{R}$ \\
\hline Allison A. Hickey & Obama & Under Secretary of Benefits & 3 (VA) & USAF & Brig General & $\mathrm{R}$ \\
\hline David H. Petraeus & Obama & Director, $\mathrm{ClA}$ & 2 & USA & General & $\mathrm{R}$ \\
\hline Marilyn A. Quagliotti & Obama & $\begin{array}{l}\text { Dep Director for Supply Redux, Office of Nat'l Drug } \\
\text { Ctrl }\end{array}$ & 3 & USA & Major General & $\mathrm{R}$ \\
\hline Jose D. Riojas & Obama & $\begin{array}{l}\text { Asst Sec of Veterans Affairs (Operations, Prep, Sec, \& } \\
\text { LE) }\end{array}$ & 4 (VA) & USA & Brig General & $R$ \\
\hline Douglas Lute & Obama & $\begin{array}{l}\text { Deputy Asst to the President for Nat'I Security } \\
\text { Affairs }\end{array}$ & PA & USA & Lt General & $\mathrm{R}$ \\
\hline
\end{tabular}




\begin{tabular}{|l|l|l|l|l|l|l|}
\hline Name & Pres & Position Title & ES Level & Service & Rank & $\begin{array}{l}\text { Retired/ } \\
\text { Active }\end{array}$ \\
\hline Karl Eikenberry & Obama & Ambassador to Afghanistan & FS (DOS) & USA & Lt General & R \\
\hline Alfonso E. Lenhardt & Obama & Ambassador to Tanzania & FS (DOS) & USA & Major General & R \\
\hline James B. Smith & Obama & Ambassador to Saudi Arabia & FS (DOS) & USAF & Brig General & R \\
\hline Jonathan S. Gration & Obama & Ambassador to Kenya & FS (DOS) & USAF & Major General & R \\
\hline
\end{tabular}




\section{Appendix 3.3: G/FOs \& RSOs in Positions of Interest Truman to Reagan}

Methodology Note: The "key" positions used from the Truman to Reagan years differed slightly from the later Bush 41-Obama data set. This difference reflects primarily the change in executive branch structure especially as related to the national security apparatus. Even across the Truman to Reagan administrations, some positions were included for some administrations but no longer existed for others. Where they existed, the following positions were included for this earlier group of presidents: Secretary and Deputy Secretary of State, Secretary and Deputy Secretary of Defense; Attorney General and Deputy Attorney General; Secretaries of the Army, Navy and Air Force; Director and Deputy Director of the CIA; Director of the FBI; Budget Director (\& Director OMB); Treasury Secretary, National Security Advisor and Deputy, Executive Secretary of the NSC, Chief of Staff and Deputy Chief of Staff (various title differences included).

\begin{tabular}{|c|c|c|c|c|c|}
\hline Name & Pres & Position Title & Branch & Rank & $\begin{array}{l}\text { Act/ } \\
\text { Retired }\end{array}$ \\
\hline George C. Marshall & Truman & Secretary of State & USA & General & $\mathrm{R}$ \\
\hline George C. Marshall & Truman & Secretary of Defense & USA & General & $\mathrm{R}$ \\
\hline Sidney W. Souers & Truman & Executive Secretary, National Security Council & USN & Rear Admiral & $\mathrm{R}$ \\
\hline Kenneth C. Royall & Truman & Secretary of the Army & USA & Brig General & $\mathrm{R}$ \\
\hline $\begin{array}{l}\text { Roscoe H. } \\
\text { Hillenkoetter }\end{array}$ & Truman & Director, $\mathrm{ClA}$ & USN & Rear Admiral & A \\
\hline Walter B. Smith & Truman & Director, $\mathrm{ClA}$ & USA & Lt General & $\mathrm{A}$ \\
\hline Lewis L. Strauss & Eisenhower & Secretary of Commerce & USN & Rear Admiral & $\mathrm{R}$ \\
\hline Robert Cutler & Eisenhower & National Security Advisor & USA & Brig General & $\mathrm{R}$ \\
\hline C.P.Cabell & Eisenhower & Deputy Director, $\mathrm{ClA}$ & USAF & Lt General & A \\
\hline Walter B. Smith & Eisenhower & Under Secretary of State & USA & General & $\mathrm{R}$ \\
\hline Wilton B. Persons & Eisenhower & Deputy Assistant to the President (Deputy Chief of Staff) & USA & Major General & $\mathrm{R}$ \\
\hline A.J. Goodpaster & Eisenhower & Staff Secretary & USA & Brig r General & $\mathrm{A}$ \\
\hline Wilton B. Persons & Eisenhower & Chief of Staff & USA & Major General & $\mathrm{R}$ \\
\hline Marshall S. Carter & Kennedy & Deputy Director of the $\mathrm{ClA}$ & USA & Lt General & $\mathrm{A}$ \\
\hline William F. Raborn & Johnson & Director, $\mathrm{ClA}$ & USN & Admiral & A \\
\hline Maxwell Taylor & Johnson & Special Counsel to the President & USA & General & $\mathrm{R}$ \\
\hline Rufus L. Taylor & Johnson & Deputy Director CIA & USN & Vice Admiral & A \\
\hline George A. Lincoln & Nixon & Director, Office of Emergency Preparedness, NSC & USA & General & $\mathrm{R}$ \\
\hline Robert E. Cushman & Nixon & Deputy Director, CIA & USA & Lt General & A \\
\hline Alexander Haig & Nixon & Deputy Assistant for Nat'I Security Affairs & USA & General & A \\
\hline Vernon A. Walters & Nixon & Deputy Director, $\mathrm{ClA}$ & USA & Lt General & $\mathrm{A}$ \\
\hline Brent Scowcroft & Ford & Deputy Assistant for Nat'I Security Affairs & USAF & Lt General & $A \& R$ \\
\hline Jeanne M. Holm & Ford & Spec Assistant to the President for Women & USAF & Major General & $\mathrm{R}$ \\
\hline Stansfield Turner & Carter & Director, $\mathrm{ClA}$ & USN & Admiral & A \\
\hline Alexander Haig & Reagan & Secretary of State & USA & General & $\mathrm{R}$ \\
\hline James W. Nance & Reagan & Deputy Assistant to President for Nat'I Security Affairs & USN & Admiral & $\mathrm{R}$ \\
\hline B.R. Inman & Reagan & Deputy Director, CIA & USN & Admiral & $\mathrm{A}$ \\
\hline John M. Poindexter & Reagan & Asst to the President for Nat'I Security Affairs & USN & Vice Admiral & A \\
\hline Colin Powell & Reagan & Deputy Assistant to the President for Nat'I Security & USA & Lt General & A \\
\hline
\end{tabular}




\begin{tabular}{|l|l|l|l|l|l|}
\hline Name & Pres & Position Title & Branch & Rank & $\begin{array}{l}\text { Act/ } \\
\text { Retired }\end{array}$ \\
\hline & & Affairs & & & \\
\hline Colin Powell & Reagan & Asst to the President for Nat'I Security Affairs & USA & Lt General & A \\
\hline
\end{tabular}




\section{Chapter 4 \\ The Military Mind and RSO Executive Branch Participation}

The modern military commander and the politician are, in most cases, very different kinds of ambitious people whose careers have taken them on very different paths; the one having risen, usually over decades, through gradually ascending ranks of responsibility, the other having struggled in the chaos of politics. One has learned to exercise command; the other to win favor and exert influence. The soldier has passed most of his life in a peaceful, structured,

hierarchical environment dominated by the rhetoric, and often the reality, of duty, fidelity, and honor: the politician, ironically, has engaged in daily, swirling combat, albeit of a bloodless kind, in which seniority and experience may suddenly count for very little...[I]t is to be expected that there would be a gap between individuals with such different experiences of life. ${ }^{238}$

Eliot Cohen, The Unequal Dialogue (2001)

The empirical results from the previous chapter show the number of retired senior military officers (RSOs) in the executive branch over the last quarter century, but this data reflects only one dimension of the military colonization question. Military colonization claims also imply that RSOs share homogenous ideological dispositions that stand in stark contrast to those of the general population, its elected leaders, and even the democratic process. But do RSOs as a group, or military officers in general, truly have a distinct, homogenous, and consistently coherent ideological orientation? If so,

\footnotetext{
${ }^{238}$ Cohen, "The Unequal Dialogue: The Theory and Reality of Civil-Military Relations and the Use of
} Force," 430-431. 
are their ideological orientations so unrepresentative of mainstream American political thought that they present acute dangers when intermixed with executive branch politics? Moreover, does a purported military mind make it inevitable that RSOs' primary institutional loyalties rest with the military and therefore these former officers exemplify burrowed advocates for the active military? Do military leaders conspire to populate the executive branch with RSOs as a way to increase military influence? Or perhaps even worse, does the hierarchical structure of the military, where discipline and obedience are paramount, produce senior officers that abhor the often messy, inefficient, and comprising nature of the democratic process and seek to "reform" it?

If the answer to any of the above questions is "yes," then military colonization presents an undeniable risk to firm civilian control over the military. Moreover, if firm civilian control is understood to mean more than just the absence of coups but also as effective bureaucratic oversight, military responsiveness to civilian leaders on matters of policy, and senior leaders providing quality military advice to civilian officials, then the potential dangers from colonization become even more evident.

This chapter approaches the issues presented above by addressing the ideological component of military colonization in three interrelated parts: the first section discusses contemporary research findings about the ideological and partisan orientations of military officers. The next section combines these extant findings on ideological orientations with the empirical data from the last chapter to situate each of the post-Cold War administrations within a RSO-executive branch relationship category. 
Finally, the third section focuses on the non-ideological or structural constraints that may influence the number of RSOs in the executive branch. For instance, statutory impediments may affect participation levels independent of the partisan, ideological, and cultural differences outlined in the first section. Legal impediments, some embedded in the Constitution, provide institutional mechanisms to bolster civilian control of the military, but some may unnecessarily and unintentionally prevent RSOs from entering executive branch service. The three sections combine to provide a richer perspective from which to assess military colonization claims as well as lay a foundation for understanding the RSO interview responses presented in the next chapter.

\section{Section 1: The Ideological Axis: The "Military Mind" and "The Gap"}

In a 1997 The Atlantic article, prominent defense correspondent Thomas Ricks described what he perceived as a widening cultural gap between the U.S. military and the American society it had sworn to defend. ${ }^{239}$ The article excited strong interest among civil-military scholars and historians, many of whom responded that this chasm, if it existed at all, was not unique to the post-Cold War period. Scholars emphasized similarities with other periods in American history such as the late $19^{\text {th }}$ century and the interwar years of the 1920s and 1930s, and noted that civil-military tensions ebbed and flowed throughout America's national development. ${ }^{240}$ According to Ricks, however, the

\footnotetext{
${ }^{239}$ Ricks, "The Widening Gap Between Military and Society."

${ }^{240}$ Weigley, "The American Civil-Military Cultural Gap: A Historical Perspective, Colonial Times to the Present," 216; Richard K. Betts, “Are Civil-Military Relations Still a Problem?,” in American Civil-Military
} 
particular admixture of changes within the military, society, and the post-Cold War security environment in the late 1990s portended especially deleterious consequences for American civil-military comity. What Ricks described as "The Gap" sparked renewed interest in earlier scholarly work on the perceived divergence of civilian leaders, civil society, and the United States military. The timing of Ricks' thesis contributed to its strong resonance because it seemed consistent with existing perceptions of vitriolic tensions between the military elite and civilian leaders during the Clinton Administration. ${ }^{241}$ Some scholars went so far as to profess that a civilian-military "crisis" was at hand. ${ }^{242}$

Despite the stir initiated by Ricks' article, his assertions primarily relied upon anecdotal evidence from interviews conducted with Marine Corps enlistees during boot camp and during their first return trips home, which made the generalizability of his findings suspect. ${ }^{243}$ Nonetheless, senior civilian and military leaders at the time acknowledged the basic underlying concern. For example, in a 1997 address at Yale, Secretary of Defense William Cohen alluded to the need to prevent a divide from “...developing between the military and civilian worlds, where the civilian world doesn't

Relations: The Soldier and the State in a New Era, ed. Suzanne C. Nielsen and Don M. Snider (Baltimore: The Johns Hopkins University Press, 2009), 11-42; Ekirch Jr., The Civilian and the Military, 108.

${ }^{241}$ Feaver, Armed Servants, 181; Weigley, "The American Civil-Military Cultural Gap: A Historical Perspective, Colonial Times to the Present," 243.

${ }^{242}$ Charles J. Jr Dunlap, "Welcome to the Junta: The Erosion of Civilian Control of the U.S. Military," Wake Forest Law Review 29 (1994): 341; Richard H. Kohn, "Out of Control: The Crisis in Civil-Military Relations I The National Interest," The National Interest, March 1, 1994, http://nationalinterest.org/article/out-ofcontrol-the-crisis-in-civil-military-relations-343?page $=4$.

243 James A. Davis, “Attitudes and Opinions Among Senior Military Officers and a U.S. Cross-Section, 19981999," in Soldiers and Civilians: The Civil-Military Gap and American National Security, ed. Peter D. Feaver and Richard H. Kohn (Cambridge, Mass: MIT Press, 2001), 15-16, http://search.lib.virginia.edu/catalog/u4373754. 
fully grasp the mission of the military, and the military doesn't understand why the memories of our citizens and civilian policy-makers are so short, or why the criticism is so quick and unrelenting." ${ }^{244}$ Ten years, and two wars later, Defense Secretary Robert Gates addressed the issue and spoke of warning signs that indicated the potential infancy of a distinct military class. This development, according to Gates, was a byproduct of the protracted wars initiated after 9/11, and he warned, "[t]he United States is at risk of developing a cadre of military leaders who are cut off politically, culturally and geographically from the population they are sworn to protect." 245

The possibility of a divide has gained renewed attention over the last decades, but the purported ideological and cultural distinctiveness between military and civilian society has always existed at the core of post-World War II civil-military studies. As described in Chapter 2, Huntington's framework viewed this distinction as both desirable and necessary. The form of military professionalism cultivated through the divide served as the linchpin for reconciling the tension between the security requirements of the state and the preservation of American liberalism. ${ }^{246}$ The necessary divide prescribed that civilians stay out of military matters and tolerate military culture's illiberal characteristics, but in return, military officers refrained from politics and accepted civilian control of the military as a central, and non-negotiable, tenet of military professionalism.

\footnotetext{
${ }^{244}$ William Cohen, "Remarks at Yale University," October 22, 1997, http://www.defense.gov/releases/release.aspx?releaseid=1459.

245 Elizabeth Bumiller, "Gates Warns of Growing Disconnect Between Country and Military NYTimes.com," The New York Times, September 29, 2010, http://www.nytimes.com/2010/09/30/us/30military.html?_r=1\&.

${ }^{246}$ Huntington, The Soldier and the State, chap. 3.
} 
Interestingly, suggestions of an ideologically homogeneous and apolitical military mind arose at the same time that other political scientists were challenging the notion that Americans in general adhered to any consistent ideological belief system. ${ }^{247}$ Although Americans were familiar with basic terms like liberal or conservative, early post-World War II survey data suggested that the populace overwhelmingly failed to reconcile their beliefs within one particular and coherent ideological framework. Some alternative findings suggested that Americans' ideological orientations were perhaps more consistent than the survey data reflected, but only when examined through an individual experiential perspective. ${ }^{248}$ Nevertheless, the ideological innocence thesis has prevailed in post-war political science and stands in contrast to homogeneity assumptions about military officers. ${ }^{249}$

Scholars of American political development have also challenged the assertion that a dominant and homogeneous strand or a grand narrative exists in American political ideology. These more traditional and historically oriented scholars opposed the exclusivity of Lockean liberalism that scholars like Hartz ascribed to American ideological beliefs. ${ }^{250}$ Taken in total, existing political science research complicates the notion that

\footnotetext{
${ }^{247}$ University of Michigan. Survey Research Center., The American Voter (New York,: Wiley, 1960); Phillip E. Converse, "The Nature of Belief Systems in the Mass Publics," in Ideology and Discontent,, ed. David E. Apter (London,: Free Press of Glencoe, 1964); A. Campbell et al., Elections and the Political Order, 99th ed. (Wiley, 1966).

${ }^{248}$ Robert Edwards Lane, Political Ideology: Why the American Common Man Believes What He Does. (New York: Free Press of Glencoe, 1962); James S. Fishkin, The Voice of the People : Public Opinion and Democracy (New Haven, Conn.: Yale University Press, 1995).

${ }^{249}$ Michael X. Delli Carpini, What Americans Know About Politics and Why It Matters (New Haven Conn.: Yale University Press, 1996), http://www.washingtonpost.com/wp-dyn/articles/A45657-2001May18.html. ${ }^{250}$ Hartz, The Liberal Tradition in America; an Interpretation of American Political Thought Since the Revolution.; Rogers M. Smith, "Beyond Tocqueville, Myrdal, and Hartz: The Multiple Traditions in America," American Political Science Review 87, no. 3 (September 1993): 549-567.
} 
consistent ideological outlooks prevail in most Americans. ${ }^{251}$ Of particular concern for the question of RSOs and military colonization then, is whether military officers somehow transcend the perceived ideological incoherence found in the broader American public and develop well-organized and consistent political ideologies that diverge from American society or its elected leaders. If so, does any ideological coherence remain in military officers after they retire?

The Project on the Gap between the Military and Civilian Society, conducted in the late 1990s and published in 2001, aimed to address this potential civil-military ideological divide. ${ }^{252}$ Under the auspices of the Triangular Institute for Security Studies (TISS), the research consortium surveyed nearly 4,900 individuals, including the general public, elite civilian leaders, and elite military officers about the role of the military in American society and national decision making. ${ }^{253}$ Completed prior to $9 / 11$, the study cannot account for the subsequent decade of wartime civil-military interaction. The study also does not specifically target RSOs. Nonetheless, the results still remain the best source for capturing attitudes at the elite military level and by implication, the attitudes of retired senior officers.

\footnotetext{
${ }^{251}$ Delli Carpini, What Americans Know About Politics and Why It Matters.

${ }^{252}$ Peter D. Feaver and Richard H. Kohn, Soldiers and Civilians: The Civil-Military Gap and American National Security (MIT Press, 2001).

${ }^{253}$ Ibid.; Holsti, "A Widening Gap Between the U.S. Military and Civilian Society?". The civilian "elite" represented a sample taken from lists such as "Who's Who in America" and other directories of prominent Americans and therefore did not include just civilian government leaders. The military sample was comprised of officer from all different career stages. The higher ranking officers in the survey were those attending service schools; these schools are typically attended by those officers who represent the "up and coming" senior officers of the military. While the survey populations don't reflect just G/FOs and senior civilian executive branch officials, the results still provide a good indication of the civilian-military cultural gap.
} 
The TISS findings support many assertions of the gap thesis, in particular those related to partisan affiliation. Political scientist Ole Holsti combined the TISS data with results from his earlier research, the Foreign Policy Leadership Study (FPLS), and found the number of military officers who self-identify as Republican has grown significantly over the last three decades. ${ }^{254}$ In 1976, 33\% of military elite identified as Republican, and by 1996 the percentage was $67 \% .{ }^{255}$ Republican affiliation increased among civilian elite during the period as well, but the Republican gains in civilians came at the expense of the independent category whereas military growth denoted a mass exodus from the Democratic Party. ${ }^{256}$ The Republican affiliation of the military officer corps, especially at the elite G/FO level, is now a generally acknowledged feature of the political landscape. ${ }^{257}$ The partisan consolidation is mainly attributed to military animosities toward Democratic leaders and left-wing politics following Vietnam, a trend that was then solidified during the Reagan defense buildup. ${ }^{258}$

The growth in Republican affiliations among officers since 1976 weakens claims that a civilian-military gap resulted primarily over the military's purported opposition to

\footnotetext{
254 Ole R. Holsti, Public Opinion and American Foreign Policy (Ann Arbor, MI: The University of Michigan Press, 1996).

255 Ole R. Holsti, "Of Chasms and Convergences: Attitudes and Beliefs of Civilians and Military Elites at the Start of a New Millennium," in Soldiers and Civilians: The Civil-Military Gap and American National Security, ed. Peter D. Feaver and Richard H. Kohn (Cambridge, Mass: MIT Press, 2001), 27. 256 Ibid.

${ }^{257}$ See Bacevich, The New American Militarism for the best account of the progression toward the Republican Party

258 Donald S. Inbody, "Grand Army of the Republic or Grand Army of the Republicans? Political Party and Ideological Preferences of American Enlisted Personnel" (Dissertation, The University of Texas, 2009), http://inbody.net/Inbody\%20Dissertation\%20Defense\%20Draft\%205-20-2009.pdf; Bacevich and Kohn, "Grand Army of the Republicans: Has the U.S. Military Become a Partisan Force?"; Dempsey, Our Army, chap. 6.
} 
Bill Clinton during the 1990 s. $^{259}$ The party migration proceeded unabated both before and after Clinton, even when a Democratic presidential candidate held veteran status (i.e, Carter, Gore, Kerry), and the opposing Republican candidates claimed only weak military affiliations (Reagan and Bush 43). ${ }^{260}$ The 2012 presidential campaign demonstrates that this affiliation gap likely remains strong, especially among RSOs. In the 2012 presidential campaign, where neither candidate had military credentials, Republican candidate Mitt Romney published a listing of over 300 RSO endorsements whereas Obama registered only a handful. ${ }^{261}$ Evidence suggests, however, that although senior officers remain strongly Republican, the overall veteran population mirrors the broader society when basic demographic traits are accounted for, possibly indicating a weakening of the migratory trend toward the Republicans. ${ }^{262}$

Self-identified ideological dispositions of the military elite also ostensibly support the gap thesis. Analyzing the TISS sample, Holsti reported that over $67 \%$ of the elite military respondents self-identified as conservative compared with $52 \%$ of elite former vet civilians and $32 \%$ of non-veteran elite civilians. ${ }^{263}$ In the public overall, $49 \%$ of

\footnotetext{
${ }^{259}$ Holsti, "Of Chasms and Convergences: Attitudes and Beliefs of Civilians and Military Elites at the Start of a New Millennium," 27.

${ }^{260}$ In fairness, both Reagan and Bush 43 had some veteran credentials; however, Reagan's status can best be described as a "Hollywood" vet, whereas Bush 43's veteran status was marred by accusations that his Guard service was simply the means to avoid Vietnam, and moreover, he failed to fulfill even this lesser military commitments by not even showing up.

${ }^{261}$ Army Times, “Mitt Romney's 'Military Advisory Council' - Army News | News from Afghanistan \& Iraq Army Times"; Golby, Dropp, and Feaver, Military Campaigns: Veterans' Endorsements and Presidential Elections.

262 Jeremy M. Teigen, "Veterans' Party Identification, Candidate Affect, and Vote Choice in the 2004 US Presidential Election," Armed Forces \& Society 33, no. 3 (April 2007): 414-437; Dempsey, Our Army. ${ }^{263}$ Holsti, "Of Chasms and Convergences: Attitudes and Beliefs of Civilians and Military Elites at the Start of a New Millennium," 33.
} 
veterans and $38 \%$ of non-vets identified as conservative. ${ }^{264}$ In a separate study that used the same TISS data but compared only military elite and the general population, James Davis found that despite their overwhelming self-identification as conservative, virtually none $(0.3 \%)$ of the military elite self-identified as far right. By contrast, $2.1 \%$ of the general population identified as such. Moreover, the number of military respondents who self-identified as very conservative, only narrowly exceeded that found in the general public, $13 \%$ to $10.6 \%$ respectively. ${ }^{265}$ The majority $(51.1 \%)$ of elite military simply defined themselves as somewhat conservative compared to $26 \%$ of the civilian population. ${ }^{266}$

In a similar study on the Army, Darrel Driver found that military service proved a poor predictor of ideological orientation. ${ }^{267}$ Regardless of the categories he used to classify civilians and military elites responses, Driver found "... no distinct conservativelike world view dominated by the military respondents." ${ }^{268}$ Like the civilian respondents, the military leaders also routinely used classic liberal terminology to articulate their political beliefs. ${ }^{269}$ His study revealed only two basic ideological characteristics among senior officers: a broad commitment to public service, and “....an ability to reconcile a

\footnotetext{
264 Ibid.

265 Davis, “Attitudes and Opinions Among Senior Military Officers and a U.S. Cross-Section, 1998-1999," 105.

266 Ibid.

${ }^{267}$ Darrell W. Driver, "The Military Mind: A Reassessment of the Ideological Roots of American Military Professionalism," in American Civil-Military Relations: The Soldier and the State in a New Era, ed. Suzanne C. Nielsen and Don M. Snider (Baltimore: The Johns Hopkins University Press, 2009), 181.

268 Ibid.

269 Ibid., 186.
} 
diverse range of public service beliefs with the requirements of military forms of public service." $^{270}$

In a 2004 study, civil-military scholar Jason Dempsey updated TISS assessments of ideological orientations in the Army. The post-9/11 revision ostensibly captured at least some war related influences on political orientations. Using data from a Citizens and Service Survey (C\&S), as well as surveys of West Point cadets, Dempsey found that self-identified ideological placement among Army officers remained consistent with the broader TISS study; $68 \%$ of Army officers placed themselves on the conservative side of the liberal-conservative continuum. Complicating gap theories, however, Dempsey also showed that while military officers consistently identified as conservative, the enlisted force matched the ideological self-placement of the general public. ${ }^{271}$ In sum, Dempsey's findings as well as those of the other scholars show that if a conservatism gap exists, it is not anchored at the polar end of the ideological spectrum.

Although elite military officers strongly self-identify as conservative, the label narrowly condenses a wide spectrum of intellectual and ideological terrain. American politics scholar Clinton Rossiter noted that conservatism is, “...one of the most confusing words in the glossary of political thought and oratory." ${ }^{272}$ Furthermore, scholar James Ceaser explains, "[c]onservatism is a movement characterized by what was once

\footnotetext{
270 Ibid., 173.

271 Dempsey, Our Army, 74.

${ }^{272}$ Clinton Rossiter, Conservatism in America., 2d ed., rev. (New York,: Knopf,, 1971), 5.
} 
known-before multiculturalists took the term hostage-as diversity." ${ }^{273}$ Despite the label's capture, the diversity shines through when examining conservative military attitudes on specific policy issues. Conservatism itself does not so much differentiate military attitudes but rather what is to be conserved. ${ }^{274}$ Scholar James Davis found that if ideological orientations are broken into component parts along the traditional economic versus social conservative dimension, senior military officers that selfidentified as conservatives best resembled the libertarian flavor. ${ }^{275}$ According to Davis's 2001 study, military elite were more liberal on social issues such as free speech and less concerned about moral decline in the country than civilian counterparts. The officers also resisted authoritarian values and were less supportive of the politics of right-wing religion than the civilian population. ${ }^{276}$ Military elite responses also showed stronger support for female equality in the armed forces compared to the general public, but they stopped short of endorsing female combat roles. ${ }^{277}$ They also belied their social liberal leanings on the issue of homosexuals in the military, which at the time senior soldiers staunchly opposed. Despite these 2001 examples of illiberal attitudes related to

\footnotetext{
273 James W. Ceaser, Designing a Polity: America's Constitution in Theory and Practice (Plymouth, UK: Rowman \& Littlefield Publishers, 2010), 141.

274 Janowitz, The Professional Soldier, a Social and Political Portrait., 242.

275 Davis, “Attitudes and Opinions Among Senior Military Officers and a U.S. Cross-Section, 1998-1999," 109.

${ }^{276}$ A dominant finding in the TISS study is the dominant hostility toward the media registered by military elite. These same officers are about as supportive of basic institutions as the general public, but the press is a glaring exception. However, this disposition does not extend to freedom of the press attitudes; elite military officers are more supportive of free speech than the mass public, and on the issue of banning books, the military was "unambiguously on the side of civil liberties." See Peter D. Feaver and Richard H. Kohn, Soldiers and Civilians: The Civil-Military Gap and American National Security (MIT Press, 2001), 460.; Davis, “Attitudes and Opinions Among Senior Military Officers and a U.S. Cross-Section, 1998 $1999, " 112$.

277 Davis, “Attitudes and Opinions Among Senior Military Officers and a U.S. Cross-Section, 1998-1999," 116.
} 
race and gender, however, current senior military officers voiced little public opposition to recent policy changes on homosexual service and the lifting of female combat exclusions. The lack of opposition may reflect a continued trend toward socially liberal attitudes among military leaders despite their continued conservative self-identification. According to Defense Secretary Leon Panetta, the Joint Chiefs were the ones who recommended lifting the combat exclusion for females although only decades earlier they exerted the strongest resistance. ${ }^{278}$

Contemporary studies also paint an ambiguous picture on how military members and civilians view each other. Holsti showed that only a measly $12.5 \%$ of military elite saw American culture as loyal. Moreover, only $3.4 \%$ of military leaders viewed society as disciplined, while nearly $77 \%$ labeled American culture as self-indulgent and $93 \%$ of elite officers described it as materialistic. ${ }^{279}$ At first glance, these findings purportedly support Ricks' gap thesis. Nevertheless the data also shows that civilian elite and the general population convey similar attitudes toward American culture. Elite civilian non-vets ascribed traits like loyalty and discipline to American society nearly twice as frequently as military elite did, but they also described national culture as materialistic and self-

\footnotetext{
${ }^{278}$ Lolita C. Baldor, "Women In Combat: Leon Panetta Removes Military Ban, Opening Front-Line Positions," January 23, 2013, http://www.huffingtonpost.com/2013/01/23/women-incombat_n_2535954.html; Martha Raddatz et al., "Interview with Former Marine Corps General: Women in Combat Long Overdue | Power Players - Yahoo! News," January 30, 2013, http://news.yahoo.com/blogs/power-players-abc-news/former-marine-corps-general-women-combatlong-overdue-123830231.html; Melissa Healy, “Powell Faces Protest Over Armed Forces' Ban on Gays : Military: At Harvard Commencement, He Says That the 'President Has Given Us Clear Direction.' The General Opposes Lifting the Prohibition. - Los Angeles Times," Los Angeles Times, June 11, 1993, http://articles.latimes.com/1993-06-11/news/mn-2038_1_harvard-commencement; Bill Clinton, My Life (New York: Alfred A. Knopf, 2004), 483-484.

${ }^{279}$ Holsti, "Of Chasms and Convergences: Attitudes and Beliefs of Civilians and Military Elites at the Start of a New Millennium," 58-61.
} 
indulgent in numbers similar to military respondents. The general population cited American culture as self-indulgent at a rate even higher than military elites, $83 \%$ to $77 \%{ }^{280}$ Perhaps more interesting, over $60 \%$ of the American public saw " $[t]$ he decline of standards and morals in American society" as the most pressing threat to national security whereas only $42 \%$ of military elite cited the same threat. ${ }^{281}$

Possibly even more relevant for gap considerations, Davis reported only $6 \%$ of elite military officers concomitantly believed that American civilians do not respect the military and the military does not respect civilians. ${ }^{282}$ Divergence based on cultural animosities and perceptions of mutual disrespect would represent a grave danger for civil-military relations, but the research findings do not depict any such trend. Instead the disparity that does exist shows that elite military officers are simply more promilitary than the general public. ${ }^{283}$ Differences of this sort likely appear across many professions, for example, between the public and teachers on pro-education scales, or across law enforcement officials and the public on law and order issues. Nonetheless, even if the gap reflects only a disjuncture based on professional affiliations like the teacher or law enforcement examples, it may be a cause for some concern. However, if the gap boils down to one of professional preferences only, its potential consequences appear much less perilous.

\footnotetext{
${ }^{280}$ Ibid., 58.

${ }^{281}$ Ibid., 43.

282 Davis, “Attitudes and Opinions Among Senior Military Officers and a U.S. Cross-Section, 1998-1999," 118.

${ }^{283}$ Ibid., 121.
} 
Military and civilian attitudes diverge somewhat on attitudes about the basic role of the military. Both groups generally agree on the relative effectiveness of the military as a tool for dealing with threats such as the emergence of China, proliferation of nuclear weapons, and cyber-attacks. ${ }^{284}$ Differences increase, however, on attitudes toward the effectiveness of the military in dealing with immigrants, refugees and drug traffickers. In these instances military elite are much less inclined to see the military as an effective instrument. ${ }^{285}$ Moreover, $19.2 \%$ and $20.9 \%$ of elite civilians, vet and non-vet respectively, saw it very important for the military, "[t]o deal with domestic disorder within the US" whereas only $9 \%$ of the military elite agreed. ${ }^{286}$ For all foreign policy roles outside of traditional combat, such as disaster relief, intervention in civil wars, humanitarian missions, and efforts to redress historical discrimination, military leaders unambiguously showed less inclination toward a military role when compared with civilian elite. ${ }^{287}$

As with international issues, military elites and civilian elites also show important convergences and divergences on domestic policy. Holsti reports that on two of the most contentious issues, abortion rights and gun control, the chasm is not impressive; $77.9 \%$ of civilian elite non-vets, and $64.9 \%$ military elite believed women and their doctors should make abortion decisions, and on handguns issues, $79.3 \%$ civilian elite

\footnotetext{
${ }^{284}$ Holsti, "Of Chasms and Convergences: Attitudes and Beliefs of Civilians and Military Elites at the Start of a New Millennium," 43.

${ }^{285}$ Ibid.

${ }^{286}$ Ibid.

${ }^{287}$ Ibid., 46.
} 
non-vet and $69.2 \%$ military elite supported more stringent controls. ${ }^{288}$ Recent anecdotal evidence on the latter issue shows a consistent attitude among prominent RSOs. During a recent interview on CNN, General (ret) Stanley McChrystal and General (ret) Michael Hayden both expressed strong support for enhanced gun control measures. ${ }^{289}$ RSO Colin Powell has also voiced support for restrictions. ${ }^{290}$

On grand strategy questions related to wartime decision-making authority, studies show that divergences do exist between elite civilian and military leaders. The direction of this divergence, however, contradicts the fears promulgated by purveyors of military colonization. In response to the statement "[i]n wartime, civilian government leaders should let the military take over running the war," $53.4 \%$ of military elite stated they strongly agree[d] or agree[d] somewhat. The same statement elicited agreement among $55.9 \%$ of elite civilian leaders who were veterans and $46.6 \%$ of non-veteran elites. In contrast, vets and non-vets in the general public agreed with this statement $76.1 \%$ and $65.4 \%$ of the time respectively. ${ }^{291}$

The figures discussed above represent only a sampling of scholarly findings and the studies rely heavily on survey research. For nearly every hint of convergence between military elite, civilian elite, and the general population, the studies find an instance of divergence. Moreover, the most comprehensive research available captures

\footnotetext{
288 Ibid., 48.

${ }^{289}$ Candy Crowley, "Interview with General Stanly McChrystal and General Michael Hayden," CNN Transcripts, January 27, 2013, http://transcripts.cnn.com/TRANSCRIPTS/1301/27/sotu.01.html. ${ }^{290}$ Jane C. Timm, "Colin Powell: The Second Amendment Calls for Regulations, You Know - MSNBC," NBCNEWS.com, January 21, 2013, http://tv.msnbc.com/2013/01/21/colin-powell-the-secondamendment-calls-for-regulations-you-know/.

${ }^{291}$ Holsti, "Of Chasms and Convergences: Attitudes and Beliefs of Civilians and Military Elites at the Start of a New Millennium," 83.
} 
only pre-9/11 attitudes. Later, but less expansive studies appear to support the preSeptember $11^{\text {th }}$ TISS findings, but the effects rising from a decade of war likely continue to influence some attitudes. Nonetheless, the sum total of the findings strongly indicates that partisan and ideological labels do not provide reliable indicators of true political orientations and they ultimately inflate differences between civilians and military elites. Once self-identified ideological orientations are compared with specific policy preferences, the purported gap between civil elites, civilian mass society, and military elites, military colonization concerns quickly become murky. Divergences between Blue and Red states, West Coast and East Coast, 1\% versus 99\%, a Republican House and a filibuster-prone Senate make the reported civil-military "gap" appear almost ordinary. ${ }^{292}$

\section{Section 2: Categorizing Post-Cold War RSO-Executive Branch Relationships}

The RSO-executive branch categories outlined in Chapter 2 incorporate the ideological dimensions discussed above, the unique RSO traits, and the empirical findings from the last chapter. This section situates each administration in a category (see Figure 4.1 below) by comparing the total number of G/FOs (active and RSOs) in key national security positions with the post-World War II average across presidential terms. ${ }^{293}$ In relation to the historical average, the post-Cold War period does show a modest uptick. Bush 41 and Obama (first term) each appointed five G/FOs, while Bush

\footnotetext{
${ }^{292}$ Hooker, "Soldiers of the State: Reconsidering American Civil-Military Relations."

${ }^{293}$ This figure, $2.88 \mathrm{G} /$ FOs \& RSOs, was calculated from the data presented in Chapter 3, Figure 9.
} 
43 appointed one to a key position during his first term but six during his second.

Clinton appointed only three total, one in his first term. Therefore, Bush 41's term, Bush 43's second term, and Obama's first term all fall above the historical norm and therefore fit best somewhere in the upper tier of the Figure 4.1 framework, either in the Accommodation or Colonization categories. Clinton's terms and Bush 43's first term fall below the historical average and therefore their placement best resembles the Separation or Estrangement depictions.

In contrast to the easily quantifiable factor for vertical axis placement, locating each administration on the horizontal Civ-Mil Divergence scale is much more difficult. As discussed earlier, purported ideological and partisan differences between military leaders and civilian officials do not appear to be sufficient indicators of tension. Therefore the actual level of conflict between military leaders and civilian leaders must be examined. Complicating this latter requirement is the fact that perceived civilmilitary conflicts often mask the true combatants. Perceived skirmishes between military leaders and civilian leaders may instead represent battles between competing civilian officials or lawmakers, inter-institutional power struggles, or even clashes between different organizations within the military. ${ }^{294}$ A former four-star officer interviewed for this project noted that some of the most contentious civil-military battles are actually proxy wars between service chiefs and operational geographic combatant commanders and their respective congressional supporters.

\footnotetext{
${ }^{294}$ Michael C. Desch, Civilian Control of the Military : the Changing Security Environment (Baltimore: The Johns Hopkins University Press, 1999), 3.
} 
These different foci of Pentagon authority often have competing strategic and/or budget priorities that are adjudicated through public congressional and administrative battles that overshadow the underlying intra-military conflict. Bob Woodward documents such a conflict between General Tommy Franks, the combatant commander, and the Joint Chiefs in the run-up to the Iraqi invasion. Woodward describes a confrontation in which Franks only half-jokingly admonished the chiefs for ostensibly challenging his planning decisions: "You Title X motherfuckers! Let me tell you something. At the end of the day, combatants, and that's either me or the boss I work for [Rumsfeld], are going to put together a joint and combined operation here and it is not going to scratch the itch of any one of the services." ${ }^{295}$ The Title $X$ statutes referenced by Franks delineate the spheres of authority of the chiefs and combatant commanders, and establish chain of command structures at the highest levels of military and civilian leadership. In this case, however, the conflict was played out in public as a civil-military conflict between Rumsfeld and the service chiefs, specifically Shinseki, and not as an internal fight among military leaders.

Disagreement among military leaders over the "surge" in Iraqi also highlights the underlying intramural dimension played out as a civil-military conflict. Moreover, civilmilitary tension may not necessarily represent a normative bad relational state in the constitutional design; a Madisonian approach may even see such conflict as desirable. ${ }^{296}$

\footnotetext{
${ }^{295}$ As quoted in Bob Woodward, Plan of Attack (New York, NY: Simon \& Schuster, 2004), 118.

${ }^{296}$ See Christopher P. Gibson, "Enhancing National Security and Civilian Control of the Military: A Madisonian Approach," in American Civil-Military Relations: The Soldier and the State in a New Era, ed. Suzanne C. Nielsen and Don M. Snider (Baltimore: The Johns Hopkins University Press, 2009), 239-263; Desch, Civilian Control of the Military, 3.
} 
In other words, the absence of tension doesn't necessarily imply healthy civil-military relations.

Despite the complications, some measure of civil-military tension is necessary in order to consider alternative categories in the RSO-executive branch relationship. The qualitative measure used in the descriptive framework therefore primarily considers the degree to which military leaders publically oppose the policies announced by civilian officials. ${ }^{297}$ The measure acknowledges that some inherent civil-military tension will always exist due to the more conservative orientation of military leaders as compared to civilian officials. However, the public visibility of the conflicts helps differentiate the levels of tension across administrations. ${ }^{298}$

The Bush 41 term and Clinton administrations are often seen as polar opposites with respect to civil-military tensions and ideological orientations not just in the postCold War period but arguably since the end of World War II. These two administrations therefore help anchor the divergence spectrum and facilitate the relative positioning of their post-Cold War successors. The relationship the framework tries to capture, however, is not static. Internal and external factors constantly exert pressures on the

\footnotetext{
${ }^{297}$ Adapted from Peter D. Feaver, "Civil-Military Relations," Annual Review of Political Science 2, no. 1 (1999): 221.

${ }^{298}$ In Civilian Control of the Military (1999) Michael Desch created a list of post-World War II disagreements between civilian officials and military leaders. The list only includes Bush 41 and the Clinton administrations in the post-Cold War period but Desch's measure provides a rough framework for comparing levels of tension. Desch does not identify his formal structure for determining which events could be classified as significant civil-military conflicts. His method instead reflects a subjective analysis of a variety of qualitative sources on each of the administrations. The discussion in this section pursues the same method for updating Desch's list to include the Bush 43 and Obama administrations. The significant disparity between civil-military conflict during the Bush 41 and Clinton administrations is noted by Desch and overwhelmingly accepted by later literature on the administrations. This large disparity provides some anchor points for the tension scale.
} 
civil-military relationship and alter its characteristics. Nonetheless, the following discussion aims to show that although shifts in categories likely occur across and between administrations, their respective sub-category traits have characteristically demonstrated little change. RSOs serving in the executive branch have consistently exhibited the soldier-statesman dimensions associated with their unique traits outlined in Chapter 2.

Although not devoid of civil-military tensions, scholars routinely describe the Bush 41 foreign policy apparatus and interagency coordination process as a model of cooperation. ${ }^{299}$ Retrospectives infer that the planning and execution of the first Gulf War exemplified effective civil-military relations and relatively few public conflicts arose between military leaders and elite civilian national security leaders. Therefore, combined with its increase in the number of RSOs, the Bush 41 administration fits most appropriately in the Accommodation category. The Clinton administration is portrayed as exhibiting highly publicized tensions and disagreements between civilian elites and military elites over national security issues, the use of force, and broader social issues. ${ }^{300}$ This environment, combined with the below average presence of RSOs in the administration, makes the Estrangement category the most accurate description of Clinton's entire tenure.

\footnotetext{
${ }^{299}$ Daalder and Destler, In the Shadow of the Oval Office, 183; Feaver, Armed Servants, 182; Richard Haass, War of Necessity, War of Choice : A Memoir of Two Iraq Wars, 1st Simon \& Schuster hardcover ed. (New York: Simon \& Schuster, 2009), 82; Bob Woodward, The War Within (New York: Simon \& Schuster, 2008), 202.

${ }^{300}$ See Feaver, Armed Servants, chap. 6.
} 
RSO-Executive Branch Relationship Categories

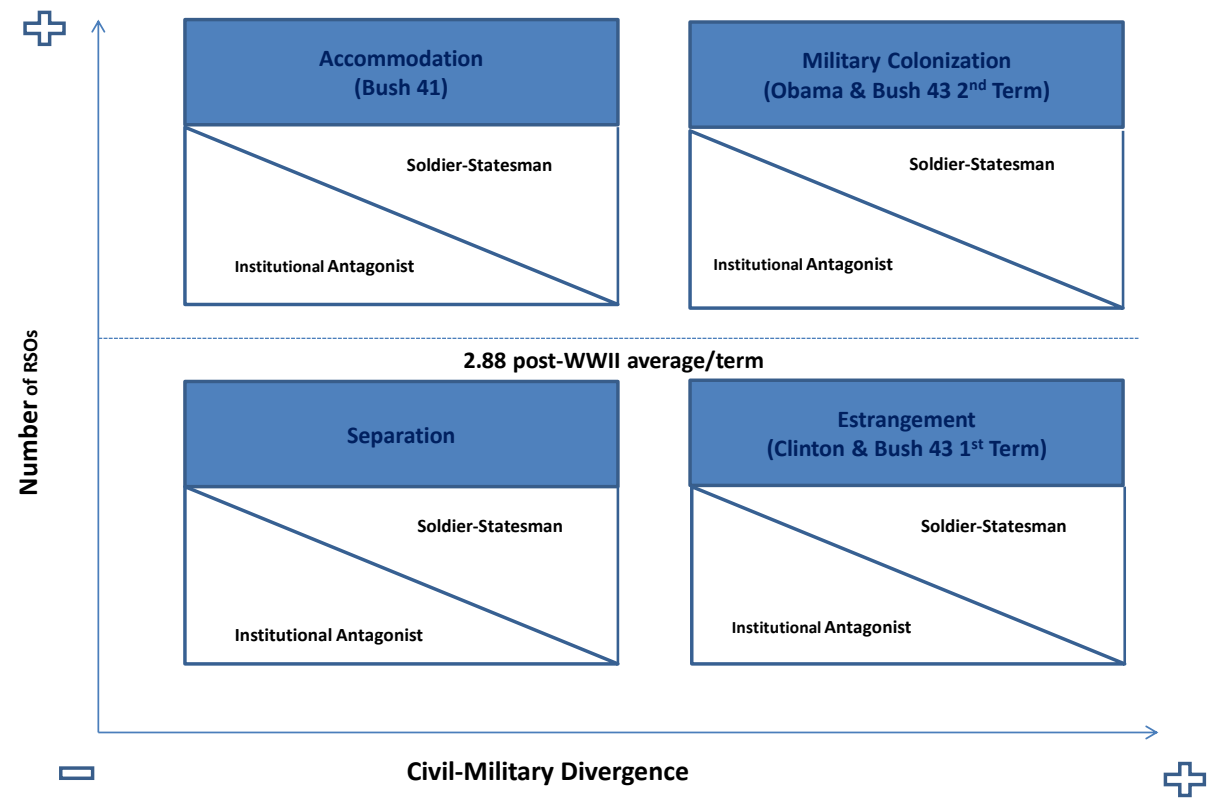

Figure 4-1: Administration RSO-Executive Branch Relationship Categories

The Bush 43 and the Obama administrations prove more difficult to anchor firmly in a category. On one hand, Bush 43's partisan affiliation and the purported conservative orientation of both the military elite and the civilian administration suggests an Accommodation assignment similar to Bush 41. However, the Bush 43 administration exhibited rather strong civil-military tensions, especially in response to Rumsfeld's transformation plans, later the Iraq War, and Rumsfeld's leadership style in general. ${ }^{301}$ Although the Bush campaign claimed that Clinton had neglected the military

\footnotetext{
${ }^{301}$ See Matthew Moten, “A Broken Dialogue: Rumsfeld, Shinseki, and Civil-Military Tension," in American Civil-Military Relations: The Soldier and the State in a New Era, ed. Suzanne C. Nielsen and Don M. Snider (Baltimore: The Johns Hopkins University Press, 2009), 42-71; Thomas E. Ricks, "Rumsfeld on High Wire of
} 
and eschewed advice from its leaders, civil-military tensions became endemic from the outset of the administration. ${ }^{302}$ As the earlier discussion hinted, and the Bush 43 example seems to bear out, ideological and partisan labels do not provide a great indicator of the degree of harmony between civil and military elite. In any case, the low number of G/FOs and RSOs in the administration, coupled with the level of civil-military tensions, makes the Estrangement category the best descriptive fit for Bush's first term. The Military Colonization block, however, best describes Bush's second term where the number of RSOs increased significantly and the tensions remained and even escalated over post-war Iraq issues.

Relying on ideological and partisan labels presents similar difficulties for situating the Obama administration. Obama, as a liberal Democrat, obviously contrasts with the dispositions traditionally ascribed to the military elite. In addition to the disparity in ideological and partisan labels, the firing of General Stanley McChrystal, Obama's willingness to promote lifting the military's homosexual ban, and the disagreement over the Afghanistan surge and withdrawal plan, all fueled civilian-military tension during the term. The strain did not reach the level of vitriol evident during the Clinton administration, but smooth sailing hardly describes the relationship. Moreover, the total number of RSOs exceeded the average. Therefore, like Bush 43's second term, the

Defense Reform: Military Brass, Conservative Lawmakers Are Among Secretive Review's Unexpected Critics," Washington Post, May 20, 2001.

302 Michael C. Desch, "Hartz, Huntington, and the Liberal Tradition in America: The Clash with Military Realism," in American Civil-Military Relations: The Soldier and the State in a New Era, ed. Suzanne C. Nielsen and Don M. Snider (Baltimore: The Johns Hopkins University Press, 2009), 91-112. 
Obama administration best fits within the Military Colonization category although less

so than his predecessor.

With each administration roughly situated within the Figure 4.1 categories, the focus can now turn to examining actual RSO behavior. This part of the analysis looks at the actions of some of the most prominent former officers in each administration and attempts to decipher which dimensions of the RSO traits they manifested: those of Soldier-Statesman or Institutional Antagonists. Table 4.1 below lists Bush 41's G/FO and RSO appointments included in the data set. The highlighted individuals remained on active duty while serving in the respective positions.

Table 4-1: Bush 41 G/FO Appointments

\begin{tabular}{|c|c|c|c|c|c|}
\hline Walters, Vernon A. & Lt Gen USA & DOS & Ambassador, Germany & & April 1989 \\
\hline Studeman, William O. & Admiral USN & $\mathrm{ClA}$ & Deputy Director $\mathrm{CIA}$ & $\mathrm{x}$ & April 1992 \\
\hline Cooper, Jerome G. & Maj Gen USMCR & DOD & Assistant Secretary AF Manpower/Reserve Affairs & & Nov 1989 \\
\hline Mendez, Enrique & Maj Gen USA & DOD & Assistant Secretary Defense for Health Affairs & & Feb 1990 \\
\hline Randolph, James G. & Maj Gen USAF & $\mathrm{DOE}$ & Assistant Secretary of Energy & & Nov 1991 \\
\hline Busey, James B. & Admiral USN & DOT & FAA Administrator & & June 1989 \\
\hline Curry, Jerry Ralph & General USA & DOT & Administrator, Nat'I Highway Traffic Safety Admin & & Nov 1989 \\
\hline Busey, James B. & Admiral USN & DOT & Deputy Secretary of Transportation & $\mathrm{X}$ & Nov 1991 \\
\hline Richards, Thomas C. & General USAF & DOT & FAA Administrator & & June 1992 \\
\hline Carey, James A. & Rear Adm USNR & FMC & Chairman, Federal Maritime Commission & & Jan 1989 \\
\hline Howe, Jonathan & Admiral USN & NSC & Deputy National Security Advisor & $\mathrm{x}$ & Nov 1991 \\
\hline
\end{tabular}

The two most prominent RSOs appointments made by Bush 41, James D.

Watkins and Brent Scowcroft, exemplify the soldier-statesman characteristics and their actions resist depictions that emphasize the negative dimensions of the ascribed RSO

traits. Bush 41's Energy Secretary, James Watkins, retired in 1986 as the Chief of Naval 
Operations, and was earlier appointed by President Reagan to lead the Presidential Commission on the Human Immunodeficiency Virus Epidemic during the height of the AIDS crisis. Watkins reportedly admitted a complete lack of expertise on the issue, but Reagan nonetheless told him, "You're just the man I want." ${ }^{303}$ Activists initially viewed the appointment of an RSO to such a position as emblematic of the Reagan administration's tepid commitment to addressing the controversial epidemic. However, Watkins' final report received plaudits, particularly for its stance against discrimination and its forceful push for more government research on the disease and prevention measures. ${ }^{304}$ The admiral's performance and recommendations were generally applauded as independent minded, pragmatic, and caring, labels not traditionally ascribed to military officers. ${ }^{305}$ After serving on Watkins' commission, a civilian medical member commented to The New York Times, "He [Watkins] really breaks the stereotype people have of a regimented military officer. He is very compassionate." ${ }^{306}$ Former JCS staff members reportedly referred to Watkins as "Hamlet" because of the painstaking effort he put toward decisions with moral implications while in the military. ${ }^{307}$ Later as Bush 41's Secretary of Energy, Watkins aggressively pushed energy conservation efforts, and, in 2001, he became chairman of the Commission on Ocean Policy where he promoted the Law of the Sea Treaty.

\footnotetext{
${ }^{303}$ William Yardley, “Adm. James D. Watkins, 85, AIDS Panel Leader, Dies - NYTimes.com,” The New York Times, July 31, 2012, http://www.nytimes.com/2012/07/31/us/adm-james-d-watkins-85-aids-panelleader-dies.html?_r=1\&.

${ }^{304}$ Bernard E. Trainor, "Man in the News: James David Watkins; A Compassionate Pragmatist," The New York Times, June 4, 1988, sec. U.S., http://www.nytimes.com/1988/06/04/us/man-in-the-news-jamesdavid-watkins-a-compassionate-pragmatist.html.

305 Ibid.

${ }^{306}$ Yardley, "Adm. James D. Watkins, 85, AIDS Panel Leader, Dies - NYTimes.com."

307 Trainor, "MAN IN THE NEWS."
} 
In a personal interview for this study, a former Air Force four-star recalled his own interaction with Watkins and attested to the admiral's unique leadership characteristics and institutional minded perspective. As a mid-level officer, the interviewed RSO served as an assistant to the Air Force Chief of Staff which gave him opportunities to witness important personnel discussions at the most senior levels of the military. He recalled one particular meeting among the joint chiefs, including Watkins, where the leaders considered promoting a highly successful two-star into a pivotal leadership post. The civilian political leaders and military leaders present equally attested to the responsiveness, can-do attitude, and the favorable image the considered officer had with civilian leaders outside of DOD. According to the interviewed RSO, Watkins interrupted the string of plaudits being heaped on the officer and simply asked, "Yes, but what does he believe." Watkins acknowledged the officer's strong record but explained to the group that it overwhelmingly demonstrated simply an ability to execute orders. In his view, he questioned the appropriateness of promoting someone to such a significant position that had not over the course of their career demonstrated a willingness to periodically challenge conventional wisdom, show independence of thought, and at times, be principled enough to risk future advancement. The interviewed officer explained that this experience significantly shaped his later convictions that military officers should exercise independent thinking and be willing to confront both civilian and military leaders over contested principles.

In short, Watkins exemplified the soldier-statesman characteristics discussed in Chapter 2; he used his cultural prestige to bring legitimacy to a moribund commission, 
used his institutional-minded leadership experiences to lead highly diverse organizations and executive departments, and he transcended the partisan divide over how to address the AIDs epidemic. He was a trusted envoy for the administration and his service can only be viewed as a model of civic-republican virtue.

Another Bush 41 exemplar of the soldier-statesman sub-category, Lieutenant General Brent Scowcroft, built a strong reputation as a consensus builder, honest broker, and ultimately is frequently considered "... a model for how the job [National Security Advisor] should be done.."308 Assessments of Scowcroft by those who worked for him on the National Security Council (NSC) rarely mention his senior military background other than occasional references to him as "General." Those who worked with Scowcroft supply no instances where they perceived his military mind as predisposed to favor military solutions or where he encouraged a disproportionate military voice or acted as a burrowed advocate in senior policy making decisions. ${ }^{309}$

In a 2004 oral history interview, foreign policy expert and Bush 41 NSC member Richard Hass articulated a putative consensus among fellow NSC officials: "I really think he's (Scowcroft) been the best at this job, better than anyone who has come before or since, and I don't mean that as any criticism of anyone who came before, it's just a compliment to Brent.... He had a close relationship with the President yet he still very

\footnotetext{
${ }^{308}$ Daalder and Destler, In the Shadow of the Oval Office, 170.

${ }^{309}$ see Miller Center Presidential Oral History Project http://millercenter.org/president/bush/oralhistory, and the Brookings Institute Oral History Roundtable, The NSC Project, 29 April 1999, http://www.brookings.edu/about/projects/archive/nsc/19990429-list
} 
much knew who was President." ${ }^{310}$ Likewise, Bush 41's Senior Director for European and Soviet Affairs on the Council, David Gompert, highlighted Scowcroft's vision of a restrained NSC noting, "Brent was really so diffident not only about operations but also about pushing policy. He had views and he had subtle ways of introducing his views, but he did not view the NSC, and certainly made it understood that we should not view our positions, as sort of a platform from which to push a particular policy." 311 Scowcroft's performance transcended partisan lines, and according to historian James Mann, it is Scowcroft, a veteran of three Republican administrations, who became the "...single individual most influential on the early foreign policy of Obama and his administration." 312

Despite his long military career and senior rank, RSO Scowcroft regularly served as a credible countervailing force to the policy recommendations of senior military leaders. As an arms control expert, Scowcroft strongly promoted a reduction in US troops in Europe as part of negotiations with the Soviets despite military resistance, and also convinced Bush to reject the military's initial plan for a head-on assault into Kuwait during the Gulf War. ${ }^{313}$ Furthermore, Secretary of Defense Cheney described Scowcroft as a powerful force in prodding what he referred to as the "reluctant generals," including Powell, into more fervently preparing the military option to dislodge Iraqi

\footnotetext{
${ }^{310}$ Miller Center. (2011). Interview with Richard Haass. Charlottesville, VA: University of Virginia. Retrieved from http://millercenter.org/president/bush/oralhistory/richard-haass

${ }^{311}$ Oral History Roundtable, National Security Council Project, Center for International and Security Studies at Maryland (CISSM) and the Brookings Institution, April 29, 1999, p. 13, http://www.brookings.edu/ /media/Projects/nsc/19990429.pdf

312 Jim Mann, The Obamians : The Struggle Inside the White House to Redefine American Power (New York: Viking, 2012), 164.

${ }^{313}$ Daalder and Destler, In the Shadow of the Oval Office, 194.
} 
forces from Kuwait. ${ }^{314}$ He also unequivocally and publically supported Cheney's decision to fire a fellow Air Force general, Chief of Staff Michael Dugan, after the general gave untimely and parochial comments to the press on the dominant role he envisaged air power would play in the Gulf War. ${ }^{315}$

Scowcroft's tenure as Bush's National Security Advisor has added relevance in the RSO-Executive Branch relationship because it closely followed Iran-Contra, often cited as the epitome of undue military influence in the executive branch. As a member of the Tower Commission charged with investigating Iran-Contra, Scowcroft drafted the final recommendations on the responsibilities of the NSA and clearly prescribed a coordinating role, one without responsibilities for operations and implementation. ${ }^{316}$

Scowcroft resigned his three-star commission before accepting the NSA position under Ford, and later maintained that "...the NSC advisor should not be an active-duty military guy." ${ }^{317}$ His broader views of proper civil-military relations also reflected a cogent institutional mindedness. When discussing the civilian-military interaction over the use of force, Scowcroft noted, "I still think the notion of the President just saying, 'OK, we'll go to war and then turn it over to the military,' is not right, nor is the

\footnotetext{
${ }^{314}$ Richard B. Cheney, Miller Center Presidential Oral History Project, March 16, 2000, http://millercenter.org/president/bush/oralhistory/richard-cheney; Daalder and Destler, In the Shadow of the Oval Office, 199.

${ }^{315}$ Feaver, Armed Servants, 238.

${ }^{316}$ Daalder and Destler, In the Shadow of the Oval Office, 169.

${ }^{317}$ Cheney, Miller Center Presidential Oral History Project.
} 
reverse....[but] if there's to be a disutility in the field or in the White House, it's better to have it in the field. ${ }^{\prime 318}$

Scowcroft's views hardly provide a recipe for producing the negative consequences implied by military colonization. Instead he exerted characteristics consistent with a soldier-statesman. Even if the Bush 41 administration is understood as temporarily exhibiting the necessary Military Colonization characteristics when civilmilitary tensions escalated during the Gulf War, Scowcroft still exemplified the credible countervailing posture that facilitated proper civil-military relationships rather than impeded them.

Fifteen years elapsed between his military retirement and his selection as Bush 41's NSA, so time itself arguably placed some critical distance between Scowcroft and active military leaders. In any case, both he and Watkins defied stereotypes that portray RSOs as possessing homogeneous military mindsets, dispositions toward expanding military influence, and disdain for the democratic process. Watkins showed that his military career structure prepared him to take on leadership challenges that related little to military concerns and Scowcroft in particular showed that RSOs can secure and promote proper institutional balances. NSC scholars Daalder and Destler best framed this aspect of Scowcroft's tenure: "[t]he most important lesson Scowcroft taught during his second stint as national security advisor was that power in Washington need not be a relative concept: you can gain and exercise power and influence without

\footnotetext{
${ }^{318}$ Brent Scowcroft, Miller Center Presidential Oral History Project, November 12, 1999, http://millercenter.org/president/bush/oralhistory/brent-scowcroft.
} 
having to deprive other players of theirs. ${ }^{\prime 319}$ Such a disposition is hardly an outlook for a harmful form of military colonization in an administration.

Turning now to the Clinton administration, the near absence of RSOs and G/FOs in senior policy positions makes this period noteworthy for this study. ${ }^{320}$ Clinton's tenure arguably contradicts expectations that better civilian control of the military will result when RSOs and G/FOs are absent from the executive branch. Despite the miniscule RSO presence, Clinton's tenure is instead often characterized as a period when the military ran roughshod on civilian leaders and according to some assessments, “...the military was essentially dictating policy to its civilian masters." ${ }^{321}$ Civil-military scholar Michael Desch created a list of prominent civil-military conflicts since World War II and assessed whether civilian or military leaders prevailed over the other in each case. Desch cited 47 such conflicts in the post-war period and in only nine instances did the military preferences win out. Six of these nine instances occurred during the Clinton administration. ${ }^{322}$

Although popular accounts depict festering civil-military tensions throughout Clinton's tenure, senior G/FOs that worked directly with the administration attest these accounts overstate the degree of conflict. ${ }^{323}$ In his 1995 autobiography, Colin Powell routinely cited that he had a strong relationship with the president during his time as

\footnotetext{
${ }^{319}$ Daalder and Destler, In the Shadow of the Oval Office, 203.

${ }^{320}$ Ibid., 222.

${ }^{321}$ Feaver, Armed Servants, 184.

${ }^{322}$ Michael C. Desch, Civilian Control of the Military : The Changing Security Environment (Baltimore: The Johns Hopkins University Press, 1999), Appendix 1.

${ }^{323}$ Daalder, Destler, and Nieting, The National Security Council Project: Oral History Roundtables: The Role of the National Security Adviser.
} 
Chairman of the Joint Chiefs. In his memoirs, Clinton praised Powell for defending him after veterans booed the president during his 1993 Memorial Day speech at the Vietnam Memorial, writing that Powell displayed "conviction and class." ${ }^{324}$ Contrary to media speculation, Powell expressed no resentment over the president's draft record, explaining:

By the will of the American people, he was our commander in chief. My lack of resentment, however, went beyond merely owing him a soldier's allegiance. I had worked in the Reagan-Bush era with many hard-nosed men-guys ready to get tough with Soviets, Iranians, Iraqis, Nicaraguans, or Panamanians - all of whom were the right age, but most of whom had managed to avoid serving during the Vietnam War. Bill Clinton, in my judgment, had not behaved much differently from these men. ${ }^{325}$

Powell's deputy during the early Clinton administration, Vice-Chairman of the Joint Chiefs David Jeremiah, also noted that tensions at the senior levels were often exaggerated in the media. He contended that the much publicized opposition to Clinton primarily existed at the lower military levels, or as Jeremiah labeled it, the "institutional 'out-there' military." ${ }^{326}$ The admiral recalled that strains at the senior levels resulted primarily from frustration over the organizational style and administrative processes of the Clinton administration rather than policy differences. Scholar Richard Kohn described the differences in this way: "Officers want clear, definitive orders delivered quickly...[p]oliticians want flexibility and choice." ${ }^{327}$ The master politician, Clinton

\footnotetext{
${ }^{324}$ Clinton, My Life, 522.

${ }^{325}$ Powell and Persico, My American Journey, 581-582.

${ }^{326}$ Admiral David Jeremiah, Miller Center Presidential Oral History Project, November 15, 2010, http://millercenter.org/president/bush/oralhistory/david-jeremiah.

${ }^{327}$ Kohn, "Building Trust: Civil-Military Behaviors for Effective National Security," 2009, 272.
} 
perpetuated ambiguity, but this orientation proved frustrating to military leaders that must implement decisions.

Clinton's choice of Les Aspin to serve as Secretary of Defense heightened and intensified the clashes over organizational style that Jeremiah references. According to Powell and Jeremiah, Aspin's untidy and undisciplined manner appalled Pentagon leaders. Powell recalled, "[w]e never knew what time Les was coming to work in the morning. Staff meetings were sporadic. When meetings were held, they turned into marathon gabfests, while attendees for subsequent meeting stacked up in the hallways." ${ }^{328}$ Like Powell, Admiral Jeremiah held a unique vantage point on civil-military interaction within the Clinton administration, but his "out-there military" distinction mentioned above ignores some relevant instances of resistance at the elite military level. For example, the Secretary of Defense reprimanded, and then retired, Air Force Major General Harold Campbell following public comments where he labeled Clinton a “...skirt chasing, dope-smoking, draft-dodging commander in chief." 329

Not only did Clinton's first administration lack an RSO presence, the president had negligible military experience in general at the senior levels that could credibly scrutinize military actions and the options uniformed leaders proposed. No RSO and only two active G/FOs held key positions in the administration: Clinton named

\footnotetext{
${ }^{328}$ Powell and Persico, My American Journey, 578.

${ }^{329}$ Eric Schmitt, "General to Be Disciplined For Disparaging President - New York Times," The New York Times, June 16, 1993, http://www.nytimes.com/1993/06/16/us/general-to-be-disciplined-for-disparagingpresident.html.
} 
Lieutenant General John Gordon deputy CIA director during his second term, ${ }^{330}$ and Lieutenant General Donald L. Kerrick served as the NSC's Director of European Affairs (1994-1995) and later as deputy national security advisor for the last six months of the administration. ${ }^{331}$

Notwithstanding the key positions, Clinton's most publicized RSO appointment, Barry McCaffrey as Drug Czar, stoked suggestions that the assignment represented an olive branch to the military. ${ }^{332}$ Early in the administration, a Clinton transition staffer purportedly snubbed McCaffrey attesting, "I don't talk to the military," which aggravated the uneasiness between the White House and Pentagon ${ }^{333}$ During his confirmation hearing, Senate leaders recognized the leverage an RSO appointee like McCaffrey would have in an administration that was trying to shed its anti-military image. However, rather than worrying that McCaffrey's stature would militarize the drug czar position, Senators, including those from the President's own party, instead were concerned that the administration would grant him too little influence. During the Senate hearing, the ranking minority member of the Judiciary committee, Joe Biden, stated: “...you [McCaffrey] have this administration by the ears. If they do not step up and give you some authority, you are in a position to say, 'I resign.' This is an election year. A man of your standing, or your consequence, your independent endeavors unrelated to the drug czar's office, you have a standing and a credibility that they will

\footnotetext{
${ }^{330}$ Gordon replaced another RSO in the deputy NSA position, Admiral William Studeman, who was appointed during the Bush 41 administration.

${ }^{331}$ See bio at http://clinton4.nara.gov/WH/EOP/NSC/html/kerrickbio.html

${ }_{332}$ Desch, Civilian Control of the Military, 32.

${ }^{333}$ O'Sullivan, Colin Powell, 103.
} 
have to listen to." ${ }^{\prime 34}$ Republicans also unabashedly framed the nomination in decidedly

military terms. Senator Grassley commented:

[s]ince the War on Drugs has been on a downhill slide over the last three years, the recruitment of an outstanding military leader to regroup our forces, rewrite our strategy and launch a new assault on this troubling problem is absolutely necessary. We must bring all our forces together. Society is demoralized about our chances of a turn around. As qualified as Gen. McCaffrey is, he cannot succeed in his task by himself. Will his Commander in Chief give him the backing that the General needs? I hope that this will be the case." ${ }^{335}$

The senators' comments demonstrate a faith that the soldier-statesman traits would predominant even in an administration ostensibly crosswise with the military. ${ }^{336}$ Despite his PAS appointment, however, McCaffrey remained distant from the inner circle of power brokers and the major national security issues of the day.

Clinton appointed two RSOs to prominent ambassadorships, Admiral Crowe to the United Kingdom and Admiral Prueher to China, but, excluding McCaffrey, only one RSO held any ES Level 1 or 2 spot: Clinton named Lieutenant General Ken Wykle

\footnotetext{
${ }^{334}$ Senate Committee on the Judiciary, Nomination of Barry R. McCaffrey to Be Director of the National Drug Control Policy. $104^{\text {th }}$ Cong., 2 d sess., 1996, 5.

${ }^{335}$ Ibid., 39.

${ }^{336}$ Only Senator Russell Feingold expressed civil-military concerns during the nomination hearing. Feingold noted: "I just want to say at the outset for the record that I do remain concerned about maintain a clear separation in our society between the military and domestic law enforcement, and I certainly do not think that you [McCaffrey] have suggested such an expansion of the military's role; but some public figures have done so, most notably Governor Lamar Alexander's recent argument in favor of the fourth branch of the military to guard the border. As you know, General, the missions of the military and domestic law enforcement are different." However, Feingold did not follow-up with any specific questions on the subject for McCaffrey. Ibid., 21.
} 
Administrator of the Federal Highway Administration, an ES Level 2 position but hardly a critical node in the civil-military relations web. ${ }^{337}$

Table 4-2: Clinton G/FO Appointments (Active-Duty Highlighted)

\begin{tabular}{|l|l|l|l|c|c|}
\hline \multicolumn{1}{|c|}{ Name } & \multicolumn{1}{|c|}{ Rank } & Dept & \multicolumn{1}{c|}{ Position } & “Key” & Confirm Date \\
\hline Crowe, William J. & Admiral & DOS & Ambassador, United Kingdom & May 1994 \\
\hline Prueher, Joseph W. & Admiral & DOS & Ambassador, China & Nov 1999 \\
\hline Govan, Gregory G. & Brig Gen USA & DOS & Chief, U.S. Delegate to the Joint Consultative Group & May 2000 \\
\hline Gordan, John A. & General USAF & CIA & Deputy Director & X & Oct 1997 \\
\hline Cooper, Jerome G. & Maj Gen UMCR & DOS & Ambassador, Jamaica & Oct 1994 \\
\hline Paige, Emmett & Lt Gen USA & DOD & Assistant Secretary for Command, Control, Comm, Intel & May 1993 \\
\hline Douglass, John W. & Brig Gen USAF & DOD & Assistant Secretary of the Navy for Research, Dev \& Acq & Oct 1995 \\
\hline Oliver, David R. & Rear Adm USN & DOD & Deputy Under Secretary for Acquisition \& Technology & May 1998 \\
\hline Durham, Archer L. & Maj Gen USAF & DOE & Assistant Secretary of Energy & June 1993 \\
\hline Gordan, John A. & General USAF & DOE & Under Secretary for Nuclear Security & June 2000 \\
\hline Herberger, Albert J. & Vice Adm USN & DOT & Administrator, Maritime Administration & May 1993 \\
\hline Wykle, Kenneth R. & Lt Gen USA & DOT & Administrator, Federal Highway Administration & Oct 1997 \\
\hline McCaffrey, Barry R. & Lt Gen USA & EOP & Director, Office of National Drug Control Policy & Feb 1996 \\
\hline Kerrick, Donald L. & Lt Gen USA & NSC & Deputy National Security Advisor & Jan 1997 \\
\hline
\end{tabular}

Although his administration contained few RSOs, Clinton did attempt to bring more into the national security policy elite. Clinton offered Colin Powell the position of Secretary of State during both his first and second terms, and according to Powell, Democrats solicited his interest in the party's vice-presidential nomination in $1992 .^{338}$ Clinton presented these offers despite Powell's previous and highly publicized opposition to candidate Clinton's Balkan policy and calls to repeal the military's

\footnotetext{
${ }^{337}$ RSOs have played an important and consistent role in the US Highway system. In 1893 General Roy Stone became the Federal Government's first special agent and engineer for road inquiry, the predecessor of the public works agency that eventually built the Interstate Highway System under RSO Eisenhower. Eisenhower appointed RSO Lucius Clay as Chairman, President's Advisory committee on the National Highway Program, and later Major General (ret) J.S. Bragdon, special assistant to the president for public works planning, headed up progress studies on the Highway program. Another RSO, Brigadier General Rich Capka led the Federal Highway Administration during the Bush 43 administration. See http://www.fhwa.dot.gov/highwayhistory/interstate.cfm.

${ }^{338}$ Powell and Persico, My American Journey, 554-556.
} 
homosexual exclusion. ${ }^{339}$ Powell claimed his decision to reject the offer related primarily to family concerns and opportunities to ensure their financial security, but also because of concerns about "the amorphous way the administration handled foreign policy." ${ }^{340}$ Clinton also nominated former Navy Admiral Bobby Rae Inman as the Secretary of Defense. Inman, who had previously served as the deputy director of the CIA in the Reagan Administration, later withdrew his name citing the character assassination he experienced following his nomination announcement. ${ }^{341}$

Clinton's RSO ambassador appointments raise interesting points related to the RSO-executive branch relationship. As mentioned previously, Admiral Crowe's appointment as ambassador to the United Kingdom invited strong suspicion that the appointment reflected a tit-for-tat deal for Crowe's endorsement during the campaign. If true, the arrangement reflects a potential institutional antagonist dimension of the RSO-executive branch relationship, a point more closely scrutinized later in Chapter 5.

In contrast to the skepticism over Crowe's appointment, the other ambassador appointment, Admiral Joseph Prueher to China, better depicts the soldier-statesman dimensions of the RSO-executive branch relationship. Prior to his military retirement and ambassador appointment, Prueher commanded U.S. Pacific Command (PACOM), the largest geographic command in the United States military. As PACOM commander, Prueher spent two years implementing administration policy in Asia and establishing

\footnotetext{
339 O'Sullivan, Colin Powell, 113-114.

${ }^{340}$ Daalder and Destler, In the Shadow of the Oval Office, 226; Powell and Persico, My American Journey, 603.

${ }^{341}$ Ann Devroy, "Adm. Inman Asks Clinton To Withdraw Nomination - The Tech," The Tech (MIT, January 19, 1994), Online Edition, http://tech.mit.edu/V113/N66/inman.66w.html.
} 
close connections with leaders across the region. Few positions offer a better perch from which to witness the dynamics of pan-Asian politics, and in particular, Chinese assertiveness. If Clinton held reservations about Prueher's understanding of administration goals, or the admiral's willingness to purse them loyally, then Prueher's tenure as commander gave the president the evidence to either allay or reinforce any reservations.

The focus on Prueher's ambassador appointment reveals a dimension to the RSO-executive branch relationship neglected to this point. While on active-duty, RSO's actually implement administration policy on a daily basis and thus they develop a track record of loyal service and a willingness to adhere to administration directives. They also gain first-hand experience with international political players. In sum, RSO appointments to these positions may actually presage more responsiveness and loyalty than untested ambassador appointees from the civilian world. ${ }^{342}$

Notwithstanding Clinton's RSO apparent recruitment effort and the indications that civilian-military relations were less quarrelsome than often depicted, Clinton's tenure still fits best in the Estrangement category. The near absence of RSOs at the senior levels, or even a G/FO at a senior NSC position, may have impeded perils associated with the institutional antagonist sub-category, but it also denied him the benefits of a trusted envoy or credible countervailing RSO. Perhaps McCaffrey represented a weak attempt to secure such a trusted envoy, but if so, his place at the

\footnotetext{
${ }^{342}$ Thanks to Admiral Harvey, who in our interview offered this perspective as a potential way to view one aspect of the RSO-executive branch relationship.
} 
periphery of national security policy delimited any effect. In total, the Clinton administration indeed belies characterization as Military Colonization, but contrary to purveyors of the institutional dangers, civilian control of the military nonetheless appeared weakened rather than bolstered by the absence of RSOs.

Bypassing the Bush 43 administration for a moment, Obama's first term provides an example of the trusted envoy and credible countervailing force the Clinton administration lacked. Like Clinton, the Obama team did not exude any strong and visible public connection to the military elite. In 2008 and 2012 Colin Powell endorsed Obama, but his support resembled less an affirmation of Obama's commander in chief credentials than, as The New York Times reporter Bumiller described, "...an action of a disgruntled member of the Bush administration, or as simply the support of one AfricanAmerican for another. ${ }^{\prime \prime 34}$ In other words, the endorsement appeared more as Powell's attempt to slap Republicans rather than a sign of comity with the military elite. Obama therefore attempted to bolster his military ties by selecting two RSOs for key positions in his new administration: Admiral Dennis Blair as the Director of National Intelligence and Marine General James Jones as the National Security Advisor. Jones in particular represented the trusted envoy absent from Clinton's earlier Democratic administrations, and Obama used him and other RSOs to provide a counterweight to the active military.

Table 4-3: Obama G/FO Appointees (Active Duty Highlighted)

\footnotetext{
${ }^{343}$ Elizabeth Bumiller, "Powell Endorses Obama - NYTimes.com," The New York Times, February 6, 2008,
} http://thecaucus.blogs.nytimes.com/2008/10/19/powell-endorses-obama/. 


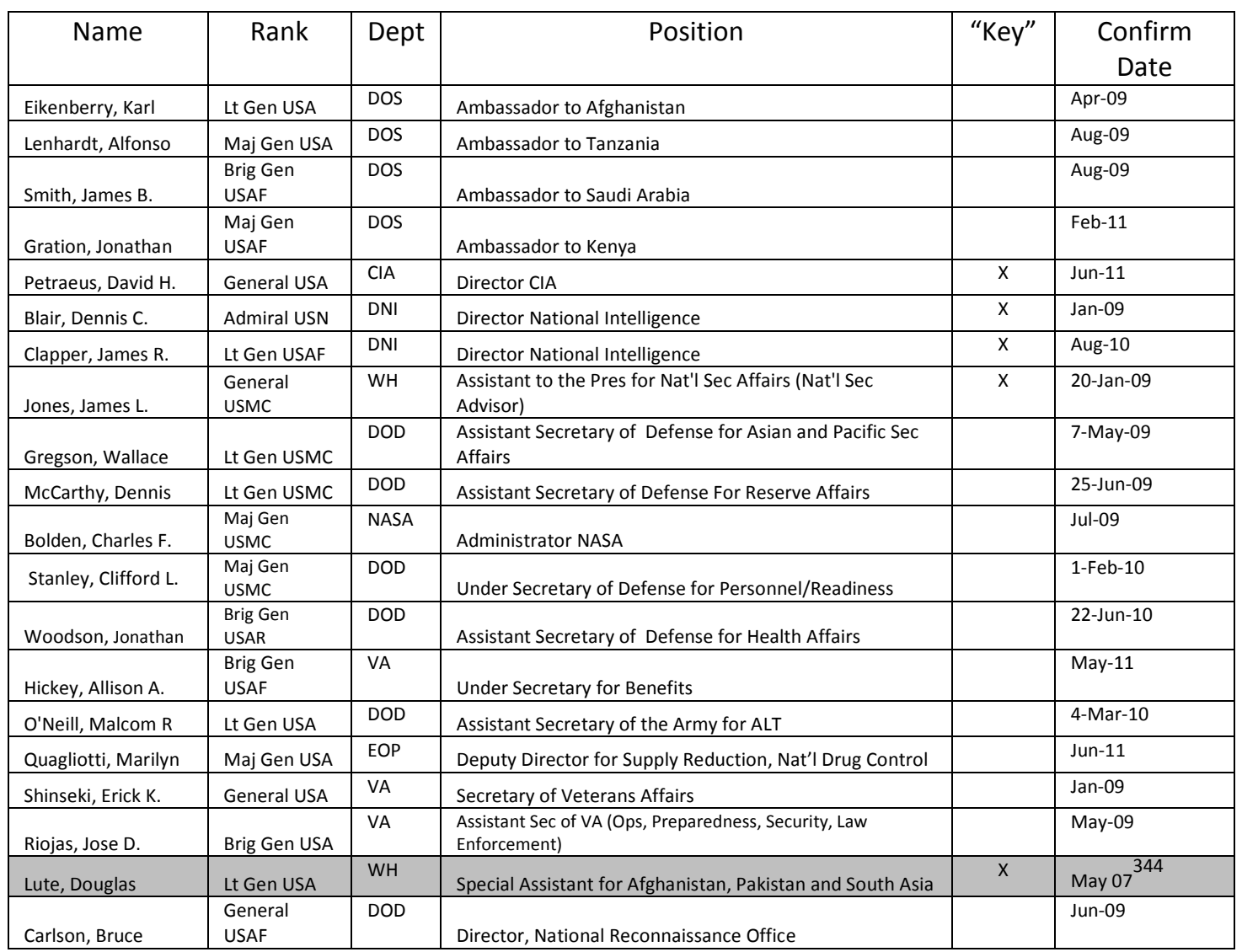

Obama relied heavily on RSOs when confronting the military elite over

differences in the Afghanistan strategy proposals and the number of additional troops

required. In Obama's Wars, Bob Woodward describes that two RSOs, the

aforementioned James Jones, and Karl Eikenberry, the Ambassador to Afghanistan,

offered the strongest critiques of the military's plans for large troop increases in region. $^{345}$

Well-respected both inside and outside the Pentagon, Jones had a strong reputation as an independent thinker on national security issues, and both political

\footnotetext{
${ }^{344}$ Lt Gen Lute was originally named Bush's "War Czar" in 2007 and Obama asked him to remain for his administration. Gen Lute retired in August 2010 but stayed in the same position as a RSO.

${ }^{345}$ Woodward, Obama's Wars.
} 
parties courted his services during the 2008 presidential election. ${ }^{346}$ Jones maintained his non-partisan image, however, stating in a Wall Street Journal article, "I've been advised by some very close friends that it's time to show your colors....Some people say, look, if you're going to survive in this town you have to decide what you are. You are either a Democrat or a Republican. But I don't agree with that." ${ }^{347}$ In an administration bereft of military experience, Jones's credentials provided Obama with credible means to assess military options. When Obama ultimately forced the commander in Afghanistan, Stanley McChrystal, to lower his troop requests, Jones's presence in the administration gave the president's decision much needed credibility with the public.

Although Jones, and also DNI Dennis Blair, initially provided Obama with visible military ties and trusted envoys, the administration discarded both RSOs unceremoniously. In Obama Wars Woodward describe that Jones's influence in the White House increasingly deteriorated at the hands of Obama's inner-circle of political operators, a circle in which Jones never became a full member. ${ }^{348}$ Like Jones, Blair lasted less than two years and had equal difficulty in adapting to the tactics of Palace politics. In his study of the Obama White House, scholar James Mann noted that Blair:

...was straightforward and he was intelligent. He was not adroit, however, at White House maneuvering or infighting. Those were skills he had never been required to learn. Blair's style was based on his long and distinguished career in the military, with its formal chain of command: Tell me who I report to, and I'Il do that say what I think, and whoever's in charge of politics can make the

\footnotetext{
346 Ibid., 36-39.

${ }^{347}$ Neil King Jr., "The Courting of General Jones - WSJ.com," The Wall Street Journal, April 23, 2007, http://online.wsj.com/public/article/SB117729466180378622-

EfRd3v5nBv3QBfi5cUh2mSLhH7U_20080422.html?mod=tff_main_tff_top.

${ }^{348}$ Woodward, Obama's Wars.
} 
political decision. He was low-key, not arrogant, but also not given to gladhandling. $^{349}$

Jones and Blair provided credible links to the military but this role ostensibly had limited shelf-life for the administration. In neither case, however, were these RSOs discarded for too closely promoting military preferences, but instead their RSO trait of transcendent politics apparently proved undesirable to administration officials.

RSO Erick Shinseki's appointment as Secretary of Veteran Affairs reveals both soldier-statesman and potentially some institutional antagonist dimensions of the RSOexecutive branch relationship. During congressional testimony prior to the Iraq invasion, Army Chief of Staff Shinseki gave an estimation of required troop strength for the postinvasion stabilization force that dramatically exceeded the estimates presented by Defense Department civilian leaders like Rumsfeld. ${ }^{350}$ Deputy Secretary Wolfowitz publically rebuked Shinseki's claims which inflamed perceptions of civil-military discord in the run-up to the invasion. ${ }^{351}$ Civil-military scholars have since described Shinseki's testimony as either courageous or as a dangerous precedent for civil-military relations. ${ }^{352}$ Shinseki displayed an independent and institutional-minded courage and willingness to voice disagreement with not only civilian leaders but also fellow military

\footnotetext{
${ }^{349}$ Mann, The Obamians, 213.

350 In his Senate testimony on military appropriations, when asked, Shinseki claimed, "...something on the order of several hundred thousand soldiers is probably a figure that would be required." See Department of Defense Authorization for Appropriations for Fiscal Year 2004, Hearings before the Committee on Armed Services, U.S. Senate, $108^{\text {th }}$ Congress, S. 1050. Pt. 1. 108, 241 (2003).

${ }^{351}$ Eric Schmitt, "Pentagon Contradicts General on Iraq Occupation Force's Size," The New York Times, February 28, 2003, Online edition, http://www.nytimes.com/2003/02/28/us/threats-responses-militaryspending-pentagon-contradicts-general-iraq-occupation.html?pagewanted=2\&src=pm.

352 Damon Coletta, "Courage in the Service of Virtue The Case of General Shinseki's Testimony Before the Iraq War," Armed Forces \& Society 34, no. 1 (October 1, 2007): 109-121, doi:10.1177/0095327X07304191; Moten, “A Broken Dialogue: Rumsfeld, Shinseki, and Civil-Military Tension"; Ackerman, The Decline and Fall of the American Republic, 52-53.
} 
leaders. However, the public attention that the episode garnered, and his cultural prestige as a G/FO, also potentially made Shinseki a pawn in partisan posturing after retiring. Shinseki's VA appointment ensconced within the Obama administration a visible reminder to the public of Republican disavowal of military advice during the previous administration. Scholar Bruce Ackerman describes the paradox produced by the Shinseki episode:

Shinseki's opposition is already playing a part in a retrospective morality play, in which the civilian Rumsfeld is cast as the archvillain and the professional military as the heroes. Like McNamara's failure in Vietnam, Rumsfeld's failure in Iraq may well discredit further aggressive efforts at civilian control for a long time to come-opening the way for future military men to dominate the political stage. $^{353}$

While not specifically aimed at Shinseki's later appointment to the VA, Ackerman's comments raise the specter that RSO appointments may contain insidious political calculations that endanger civil-military relations. However, Shinseki has yet to publically vent or show animosity toward his former Pentagon bosses who arguably dismissed his professional advice and reputation, or show an inclination to parlay his notoriety into higher political office. ${ }^{354}$

Another noteworthy dimension of the RSO-executive branch relationship in the Obama administration relates to the two high-profile dismissals during the president's first term. The sackings directly relate to interactions between the active military and RSOs within the administration. The derogatory remarks made by McChrystal's staff to a Rolling Stone writer and that ultimately led to his dismissal were in large part aimed at

\footnotetext{
353 Ackerman, The Decline and Fall of the American Republic, 52-53.

${ }^{354}$ Moten, “A Broken Dialogue: Rumsfeld, Shinseki, and Civil-Military Tension," 71.
} 
RSO and Ambassador to Afghanistan Karl Eikenberry. Former Army three-star

Eikenberry, like fellow RSO James Jones, strongly critiqued McChrystal's overall

Afghanistan strategy, and opposed the large troop increases proposed by the military commander. ${ }^{355}$ In the other RSO-G/FO episode, RSO and DNI Director James Clapper encouraged Petraeus's resignation following the exposure of his extra-marital affair despite some hints from influential congressional members that the resignation was unnecessary. ${ }^{356}$ The relationship of these figures, Jones, Eikenberry, McChrystal, Petraeus, and Clapper, belie suggestions that "generals talking to generals" somehow represents a collusion of homogeneous military minds operating solely to advance the narrow interests of the Pentagon. Instead, these RSOs provided competent leadership and credible countervailing for an administration with little military experience, and gave it the ability to publically counter military recommendations without undermining public confidence.

Notwithstanding the generally favorable depictions of RSOs in the last paragraph, Obama's appointment of Air Force Major General (ret) Jon Gration as Ambassador to Kenya evidences some of the negative stereotypes often associated with RSOs. Gration served as an advisor to the 2008 Obama campaign and his appointment had particular salience due to the President's Kenyan ties. Gration resigned the

\footnotetext{
${ }^{355}$ Michael Hastings, "The Runaway General | Politics News | Rolling Stone," Rolling Stone, June 22, 2010, http://www.rollingstone.com/politics/news/the-runaway-general-20100622; Marybeth P. Ulrich, "The General Stanley McChrystal Affair: A Case Study in Civil-Military Relations," Parameters (Spring 2011): 86100.

${ }^{356}$ Mike Roe, "California Sen. Feinstein Says She Wishes Obama Had Not Accepted Petraeus Resignation," KPCC, November 9, 2012, http://www.scpr.org/blogs/news/2012/11/09/11015/california-sen-feinsteinsays-she-wishes-obama-had/.
} 
ambassador post after less than a year and only hours before the State Department Inspector General released a report highly critical of his leadership and "imperial" managerial style. ${ }^{357}$ A key judgment in the report stated:

The Ambassador has lost the respect and confidence of the staff to lead the mission. Of more than 80 chiefs of mission inspected in recent cycles, the Ambassador ranked last for interpersonal relations, next to last on both managerial skill and attention to morale, and third from last in his overall scores form surveys of mission members. The inspectors found no reason to question these assessments; the Ambassador's leadership to date has been divisive and ineffective. ${ }^{358}$

Gration is undoubtedly not the first ambassador, nor likely the last, to resign following accusations of confrontational or ineffective management styles. The nature of the accusations against Gration, however, comports with stereotypical images of the organizational friction caused when RSOs assume leadership positions in civilian bureaucracy. Gration's tenure suggests that leadership and management styles that ostensibly led to career success in the military may not fit well in other government organizations; however, Gration's uninspiring tenure and exhibited democratic disdain stand as an apparent exception among Obama RSO appointments.

The discussion on the Bush 43 administration is saved for last because the empirical evidence does reflect a noticeable increase in G/FOs and RSOs in the executive-branch, especially in his second term. In the key policy positions, however, Bush's first term actually reflects a lower than average presence; Colin Powell was the

\footnotetext{
357 Jeffrey Gettleman, "Scott Gration Resigns as U.S. Ambassador to Kenya - NYTimes.com," The New York Times, June 29, 2012, http://www.nytimes.com/2012/06/30/world/africa/scott-gration-resigns-as-usambassador-to-kenya.html?_r=0.

${ }^{358}$ United States Department of State, Office of Inspector General, Inspection of Embassy Nairobi, Kenya, August 2012, http://oig.state.gov/documents/organization/196460.pdf.
} 
only senior RSO appointment. Powell's assertive voice as the Chairman of the JCS during the Bush 41 and early Clinton administration, as well as his own personal magnetism, gave his appointment as Secretary of State added gravitas in terms of civilmilitary relations. In Rise of the Vulcans, James Mann suggests that although Bush 43 made Powell his first cabinet appointment with great fanfare, the new president then built the rest of his cabinet to counter Powell's influence. In particular, Bush redirected Donald Rumsfeld from his expected appointment as CIA chief to the Secretary of Defense position as ballast for Powell, which set the stage for the contentious relationship between the two departments. ${ }^{359}$

As mentioned, the low number of RSOs and the elevated civil-military tensions in the first Bush 43 administration make the Estrangement category the less than perfect yet best fit with respect to the RSO-executive branch framework. Within this Estrangement category, Powell's presence much better resembles the soldier-statesman characteristics rather than the institutional antagonist features. After the post-9/11 transition to a Military Colonization category, Powell became a credible countervailing force rather than any type of burrowed advocate for the Pentagon. Powell rebuked Pentagon pressures applied both via the active military but also its civilian leadership. His publicized disagreements with top generals during the Iraq War, especially General Tommy Franks, demonstrated his willingness to counter Pentagon pressure and use his RSO stature to force further consideration of non-military options. ${ }^{360}$ A more significant

\footnotetext{
359 Jim Mann, Rise of the Vulcans : The History of Bush's War Cabinet (New York: Viking, 2004), chap. 17; Woodward, The War Within, 48-52.

${ }^{360}$ Woodward, The War Within, 47.
} 
example of resistance to the Pentagon, yet tragic for Powell's reputation in retrospect,

was his willingness to promote the administration's rational for the Iraq invasion at the UN despite the opposition of military elites. ${ }^{361}$ While ultimately Powell's UN testimony proved egregiously wrong, the act itself exemplified his willingness to resist rather than uniformly promote Pentagon preferences and/or cave to pressures from other RSOs publically opposing the military action. ${ }^{362}$

Table 4-4: Bush 43 G/FO Appointees (Active-Duty Highlighted)

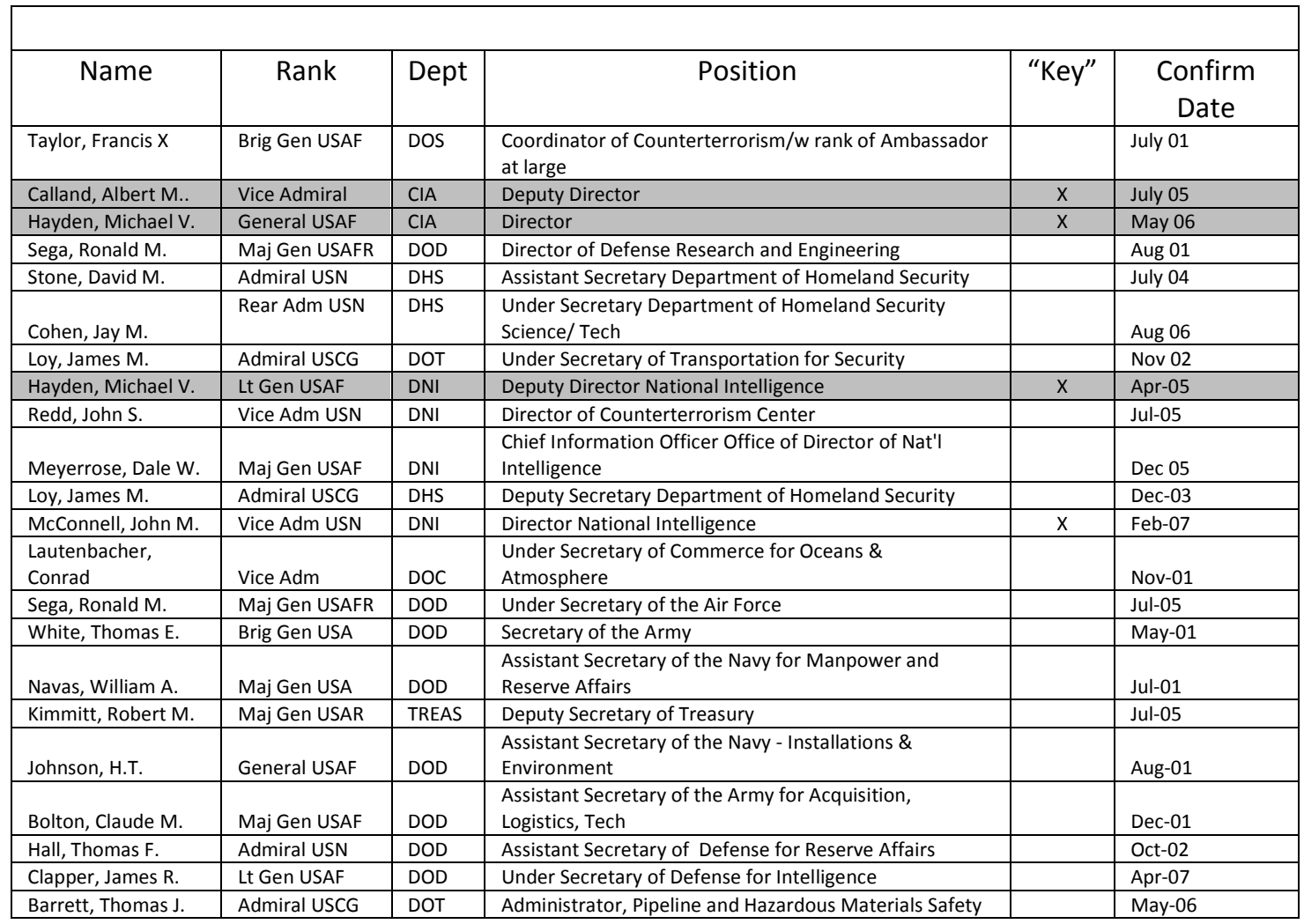

${ }^{361}$ Ibid., 46.

${ }^{362}$ One of the loudest voices against the invasion was Marine RSO General Anthony Zinni who was a former CENTCOM Commander and highly respected officer both among military and civilian elites. See http://www.cbsnews.com/8301-18560_162-618896.html. 


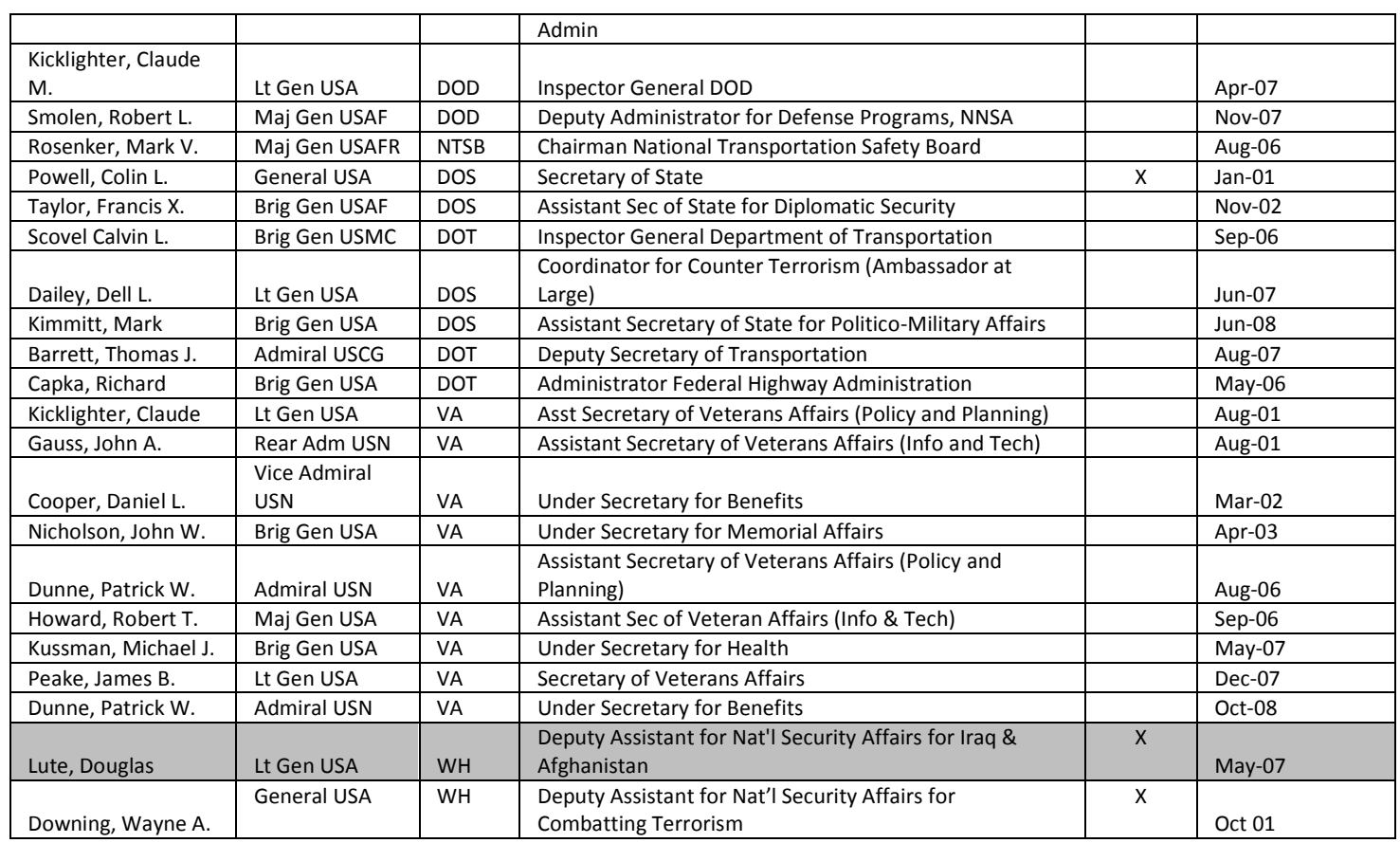

As noted earlier, Bush's second term exceeded the historical average of RSOs and G/FOs in the key national security positions causing a category shift from Estrangement to Military Colonization. Seven G/FOs received appointments to key positions, three of which were RSOs. ${ }^{363}$ Four of the seven appointments were to positions within the intelligence community. The increased number of RSO appointments, however, obscures the point that only three of the second term key RSO appointments served concurrently. This observation potentially weakens the true colonization character of the administration.

Active-duty Lieutenant General Douglas Lute, and RSO General Wayne Downing, served as deputy national security advisors in the Bush 43 administration and represent excellent examples of a broad institutional mindset in senior military officers and a

\footnotetext{
${ }^{363}$ General Michael Hayden began his tenure as CIA chief while still on active-duty, but retired from the military in July 2008 and served the last seven months of the Bush administration as an RSO.
} 
corresponding willingness to act as trusted envoys and credible countervailing forces. Earlier in the Clinton administration and at the request of Secretary of Defense William Cohen, RSO Downing acted as a trusted envoy and led an investigation of the Khobar Tower bombings that had killed 19 American service members in Saudi Arabia. Issued only months after his retirement, Downing's report laid out a scathing indictment of the military chain of command all the way up to the Chairman of the Joint Chiefs. ${ }^{364}$ Following the 9/11 attacks, President George W. Bush named Downing to the deputy NSA position, but the RSO served only a year in the job. Downing reportedly departed because of frustration with the pace of the civilian bureaucracy in planning and implementing post-9/11 changes. ${ }^{365}$ During his short tenure, however, Downing piercingly critiqued Iraq war plans, and even developed an alternative plan to topple Saddam Hussein using Iraqi exiles, U.S. airpower, and drastically fewer US troops. ${ }^{366}$ Active military leaders strongly opposed the "Downing Plan," but this effort, as well as his strong rebuke of military leaders in the Khobar bombing investigation, provide clear evidence that RSOs can and do serve as critical countervailing voices.

General Lute, Bush 41's designated War Czar, highlights another distinctive aspect of the RSO-executive branch relationship. Despite his service in the Bush administration, the Obama administration retained Lute in the deputy NSA position as

\footnotetext{
${ }^{364}$ Adam Bernstein, "Wayne A. Downing, 67; Army General Was a Prominent Advisor on Terrorism," Los Angeles Times, July 19, 2007, http://articles.latimes.com/2007/jul/19/local/me-downing19; Wayne A. Downing, Report to the President and Congress on the Protection of U.S. Forces Deployed Abroad (Washington DC: Downing Assessment Task Force, August 30, 1996), http://www.au.af.mil/au/awc/awcgate/khobar/downing/toc.htm.

${ }^{365}$ Thom Shanker, "Gen. Wayne A. Downing, 67, Special Operations Leader, Dies - New York Times," The New York Times, July 19, 2007, http://www.nytimes.com/2007/07/19/washington/19downing.html?_r=0. ${ }^{366}$ Bernstein, "Wayne A. Downing, 67; Army General Was a Prominent Advisor on Terrorism."
} 
an active G/FO and then as an RSO following his retirement. Bob Woodward noted, "[i]t might be easy to assume he (Lute) was another 'Bush general,' but Lute had a streak of daring independence." ${ }^{367}$ During the Afghanistan surge debates, Lute highlighted to civilian White House leaders faulty and perhaps deceiving calculations on required troop numbers being submitted by the Pentagon. Deputy national security advisor Tom Donilon recognized the important countervailing role played by Lute commenting:

This is exactly why we kept these guys, because they know what the hell's going on...we never would've caught this. We would've had the president and press releases approve one number, only days later to have to come back and increase the number, make us look foolish. ${ }^{368}$

Lute's institutional mindset allowed him to act as a bulwark against Pentagon pressure. Like Downing, Lute's actions transcended partisan change in presidential administrations.

In short, the empirical evidence suggests that while the post-Cold War number of RSOs increased slightly from historical norms, RSO performance in the executive branch belies any presence of a homogenous military mind that looks primarily to military solutions or impedes true civilian control of the military. The unique soldierstatesmen characteristics of RSOs allow them to promote military interests when necessary, but also to resist undue military influence as honest brokers in executive administrations. Military colonization claims may too easily discount this potential role. For example, Ackerman's depiction of the dangers of military colonization acknowledges

\footnotetext{
${ }^{367}$ Woodward, Obama's Wars, 41.

368 Ibid., 96.
} 
that Scowcroft and Powell partially redeemed the NSA position after the Iran-Contra debacle, but he then quickly dismisses them as intellectual lightweights compared to the likes of Kissinger and Brzezinski. He indeed may be right on the latter account; however, in Washington, intellectual heavyweights are arguably commonplace. Scowcroft, Powell and the others mentioned above instead used their unique leadership talents and institutionally minded dispositions to ensure the grand products of so-called intellectuals received proper scrutiny by executive branch principals and did not fall prey to undue military influence. In this role they arguably served the democratic process and governing machinery better than Ackerman's intellectuals. It is perhaps notable that Anthony Lake, Clinton's national security advisor in the least militarized and arguably most intellectual of administrations, cited Generals Goodpaster and RSO Scowcroft as the role models for the NSA, the position most targeted by purveyors of military colonization. ${ }^{369}$ Regardless of what category each administration exemplifies, RSOs in the executive branch have overwhelmingly demonstrated they can best be understood as soldier-statesmen.

\section{Section 3: Legal and Organizational Barriers to RSO Executive Branch Service}

Ideological and partisan dimensions influence the RSO-executive branch relationship but a myriad of other factors also contribute to its character. To help transition to the upcoming discussion of the RSO perspective, this chapter closes with a

\footnotetext{
${ }^{369}$ Daalder, Destler, and Nieting, The National Security Council Project: Oral History Roundtables: The Role of the National Security Adviser.
} 
brief look at the historical context of legal barriers to RSO participation. Many legal statutes reflect foundational principles and concerted efforts to impede undue military influence but others arguably have produced unintentional consequences for the relationship.

Debates on institutional devices to impede military officers from serving in other official government positions have been common throughout American political development and became a central issue during the Constitutional Convention. In some cases, the ratified provisions designed to address the issue and ensure civilian control of the military leap out of the Constitution. For example, Congress's Article I, Section 8 enumerated powers to declare war, raise and support armies, provide and maintain a navy, call forth the militia, and the power to regulate these forces, provide clear institutional structure to civilian-military relations and the role of senior military leaders. ${ }^{370}$ However, other perhaps more subtle provisions also reveal the Founder's ideas regarding civilian-military relations. ${ }^{371}$ In particular, debates over what would become Article 1 Section 6 of the Constitution, provide significant insight into the Founder's image of the military leader and their possibilities for executive branch service. The final provision stated:

No Senator or Representative shall, during the Time for which he was elected, be appointed to any civil Office under the Authority of the United States, which shall have been created, or the Emoluments

\footnotetext{
${ }^{370}$ U.S. Constitution, Article 1, Section 8

${ }^{371}$ Ackerman argues that the Founder's intended for political leaders to assume military roles as a means of exerting civilian control over the military. He labeled this type of control "participatory" control as opposed to "supervisory" control where Americans rely on democratically elected leaders to keep officers in place.
} 
whereof shall have been increased during such time; and no Person holding any Office under the United States, shall be a Member of either House during Continuance in Office. ${ }^{372}$

This provision clearly elucidates the dominant commitment on behalf of the Framer's to demarcate institutions, but it also reveals their expectation that national leaders would transition between civil and military service. Representatives and Senators could not create and subsequently serve in a new civil position in the separated executive branch, but the door was open to assume military positions should the need arise. Based on convention notes, the delegates envisaged that the leadership attributes of political figures directly transferred to military leadership competencies, and thus provisions should not impede them. Convention notes capture James Wilson's hesitancy to impose any restriction:

Strong reasons must induce me to disqualify a good man from office. If you do, you give an opportunity to the dependent or avaricious man to fill it up, for to them offices are objects of desire. If we admit there may be cabal and intrigue between the executive and legislative bodies, the exclusion of one year will not prevent the effects of it. But we ought to hold forth every honorable inducement for men of abilities to enter the service of the public. - This is truly a republican principle....Suppose a war breaks out and a number of your best military characters were members; must we lose the benefit of their services? Had this been the case in the beginning of the war, what would have been our situation?-and what has happened may happen again. ${ }^{373}$

Wilson likely added the last sentences in deference to Washington, and other, albeit less prominent veteran-delegates. Nevertheless, the crux of his argument suggests that despite the potential dangers presented by designing men, the benefits provided by

\footnotetext{
${ }^{372}$ U.S. Constitution, Article 1, Section 6

373 United States. Constitutional Convention, The Records of the Federal Convention of 1787,, vol. 1 (New Haven,: Yale University Press,, 1911), 379-380.
} 
harnessing the abilities of citizens of high-character, regardless of their previous

profession, outweighed this risk. In a prelude to an underlying theme in the Federalist,

Alexander Hamilton conveyed how the innate psychological motivations of men can

produce republican advantages:

I confess there is danger where men are capable of holding two offices. Take mankind in general, they are vicious - their passions may be operated upon....Take mankind as they are and what are they governed by? Their passions. There may be in every government a few choice spirits, who may act from more worthy motives. One great error is that we suppose mankind more honest than they are. Our prevailing passions are ambition and interest; and it will ever be the duty of a wise government to avail itself of those passions, in order to make them subservient to the public good-for these ever induce us to action. Perhaps a few men in a state, may, from patriotic motives, or to display their talents, or to reap the advantage of public applause, step forward; but if we adopt the clause we destroy the motive. I am therefore against all exclusions and refinements, except only in this case; that when a member takes his seat, he should vacate every other office. ${ }^{374}$

Removing barriers that restricted legislators from serving in a military capacity also paradoxically provided a means of civilian control. Allowing political leaders to periodically enter the military and then subsequently return to their civil leadership position impeded the development of an ambitious military class that may resist democratic control. ${ }^{375}$

Admittedly, these Founding debates focus primarily on individuals holding military and civilian positions concurrently and across separated branches. Officers that serve in official positions after retiring undeniably present a distinctly different issue.

\footnotetext{
${ }^{374}$ Ibid., 1:381-382.

${ }^{375}$ Ackerman Chapter 2
} 
However, the early discussions embody a particular theoretical strand that remains relevant to the study of RSOs and the executive branch, a strand neglected in public discourse today. Contemporary debates on RSO participation seem instead to predominantly focus on the relative benefits of capitalizing on their professional expertise or apolitical image. Furthermore, statutory concerns heavily focus on ethics issues related to business conflicts of interest rather than the foundational concerns of institutional theory that preoccupied Wilson, Hamilton and others. ${ }^{376}$ The Founding debates provide a reminder, however, that the channeling of ambitions in liberaldemocratic societies must always remain in focus.

Fast-forwarding to the post-Cold War period, current statutes variously reflect the commitment to institutional barriers that impede military officers serving in civilian executive branch positions. As previously mentioned, existing statutes mandate a temporal gap between military service and some top executive branch positions: in the Department of Defense the Secretary, Deputy Secretary, Under Secretary for Policy, must have a seven year respite between active service and presidential appointment, and service secretaries must wait five years. ${ }^{377}$ Similar legal restrictions, however, prevail only sporadically across departments and agencies outside DOD.

Until 2000, Dual Compensation provisions created disincentives for pursing executive branch positions for all retired government officials, including RSOs, and these

\footnotetext{
${ }^{376}$ National Academy of Public Administration, Independent Assessment of the Department of Defense Review of Post-Employment Restrictions, February 2012, http://www.napawash.org/wpcontent/uploads/2012/05/FINAL-Academy-Panel-Report-DoD-Post-Employment-Review-Assessment.pdf. ${ }^{377}$ U.S.C: Title 10 Section 113
} 
restrictions extended across all executive departments. Since they applied to all federal workers, civil-military relation concerns ostensibly did not motivate these restrictions, but the restraints nonetheless likely influenced RSO participation. ${ }^{378}$

The National Defense Authorization Act of 2000 repealed two provisions of the Dual Compensation Act of 1964 and removed some of the financial disincentives faced by RSOs. ${ }^{379}$ Under the original 1964 act, a military retiree forfeited a substantial portion of his/her retired military pay if they served in a civilian executive branch position. Those who accepted federal employment could keep the first $\$ 10,000$ of retired military pay (1964 levels), but only half of the remaining entitlement. The 1964 provisions excluded retirement pay based on a disability and the statute also granted an exception for some temporary civilian jobs. The restrictions did not apply to retired enlisted members or reservists, but focused more squarely on regular officers. In many cases, a retired military officer in a relatively low-level federal civilian position would earn less overall than their retirement pay alone. The 1964 act also mandated a fresh start for military retirees who accepted a federal civilian job. This meant that an officer's 20 plus years of military service was ignored when calculating benefits for the new position, i.e., vacation time, seniority, etc. ${ }^{380}$

\footnotetext{
${ }^{378}$ Bruce D. Callander, “New Rules on Dual Compensation," Air Force Magazine, January 2000; Biderman, "Sequels to a Military Career: The Retired Military Professional."

${ }^{379}$ United States. Congress, "National Defense Authorization Act for Fiscal Year 2000 : Conference Report to Accompany S. 1059.," 1999, sec. 651, http://search.lib.virginia.edu/catalog/011333023.

${ }^{380}$ United States. Congress, "Civil Service Reform Act of 1978 : Conference Report to Accompany S. 2640," 1978, http://search.lib.virginia.edu/catalog/u5073864.
} 
In the late 1970s, at the nadir of public and governmental support for the military in the post-World War II period, another act, the Civil Service Reform Act of 1978 put even more teeth into Dual Compensation prohibitions. ${ }^{381}$ The updated act effectively encompassed all retired members, officer, enlisted, and reserve, and the statute granted no exemptions for disability pay. Furthermore, it capped total overall compensation, to the ES Level-5 pay scale.

Congress's repeal of the Dual Compensation restrictions in the 2000 National Defense Authorization Act was in part a reaction to the unforeseen consequences related to military downsizing as well as the corresponding personnel drain on specific types of expertise due to improved economic opportunities in the private sector. Shortages of military pilots and difficulties in maintaining appropriate levels of medical doctors, for example, forced Congress to readdress the provisions. Retired military pilots, military doctors, and other specially trained officers, when allowed to fill civilian government positions upon retiring, easily assumed some administrative and technical responsibilities. Hiring the retired personnel then enabled the remaining active-duty specialists in these career fields to focus solely on operational requirements. ${ }^{382}$ Supporters envisaged that by removing the provisions, more individuals would remain in the military until retirement and develop further expertise that could then be transferred to civil government positions. Assumedly, removing the dual compensation penalties would lessen incentives for military members to jump ship early. If these

${ }^{381}$ Ibid.

${ }^{382}$ Callander, “New Rules on Dual Compensation.” 
individuals knew opportunities would still exist after retirement, then staying in the military until retirement did not foreclose later options.

In addition to dual compensation barriers, other regulations levied employment restrictions directly on all retiring government officials, military or civilian and continue to do so. The restrictions generally apply to all military officers (and in most cases retired enlisted as well), but RSOs typically face the most stringent prohibitions. Ethics statutes apply to retired government officials who pursue employment with businesses and organizations that deal directly with the government, especially those with a direct financial interest in government policy decisions. In some cases, statues place a lifetime ban on representing any outside interest back to the government. ${ }^{383}$ Other ethics statutes specifically address RSOs and executive branch employment, but their permeable exceptions make them rather innocuous. For example, U.S. Code mandates that retired members of the armed forces cannot be appointed to an executive branch position for 180 days after retirement. However, both the relevant department Secretary and the Office of Personnel Management can waive the restriction if either the basic pay of the civilian position has increased because the job is difficult to fill, or if the country is in a state of national emergency. ${ }^{384}$ Since the President confers appointments to all ES level positions and therefore supervises the waiver authority, the rule becomes moot. In any case, the language in the applicable codes, specifically the 180-day restriction, more likely reflects an intention to avoid perceptions of favoritism

\footnotetext{
${ }^{383}$ For summary of restrictions see National Academy of Public Administration, Independent Assessment of the Department of Defense Review of Post-Employment Restrictions.

${ }^{384}$ U.S.C: Title 5 Section 3326
} 
in hiring practices and contract malfeasance rather than any focused concern about civil-military relations.

In sum, while some current statutes relate to RSO participation in executive branch politics, in practice they do not appear overly burdensome. As we'll see, in the interviews conducted with RSOs, the former officers rarely mentioned legal concerns as significant factors or impediments that influenced their decision to pursue a senior executive branch position. If legal barriers present only minor obstacles, then other explanatory factors related to actual participation rates must be further considered. The next chapter analyzes interview responses from RSOs that reveal their own perspective on potential factors. What real or imagined barriers, incentives or disincentives do RSOs perceive, and how do these obstacles relate to military colonization and ultimately civil-military relations. 


\section{Chapter 5 RSOs \& the Executive Branch: The RSO Perspective}

A more egregious error never took possession of the mind of an American than the notion that a military officer should take no part in political affairs. I am an officer of the Army, and although I am perfectly aware that honor and honesty require of me the faithful execution of every duty imposed upon me by my office; yet, am I equally convinced that I should be fostering the spirit of an abject hireling, if I did not fearlessly and freely speak and act, in reference to my political rights, as became an American citizen.

The preceding chapters displayed the frequency of retired senior military officer (RSO) participation in the post-Cold War executive branch and used the RSO-executive branch categories to consider alternate ways to understand the roles they played in these administrations. However, the question of why some RSOs choose to serve or not serve in the executive branch remains unexplored. This is a critical question to consider with respect to military colonization claims. If RSOs view executive branch service as primarily an opportunity to promote the narrow interests of the military or to impose a form of military efficiency as a corrective for the disorderliness of democratic politics, then colonization claims require added attention. As the last chapter demonstrated, however, the most prominent executive branch RSOs in the post-Cold War period did not exhibit behavior consistent with these possibilities. This chapter further explores the RSO-executive branch relationship by analyzing responses collected through 
personal interviews that reveal how RSOs themselves view service in civilian administrations.

In thirteen individual interviews, RSOs discussed their perceptions of both practical and normative aspects of the RSO-Executive branch relationship as well as their ideas on the appropriate political behavior for retired senior officers. ${ }^{385}$ Interview responses from various oral history projects also supplement the data collected specifically for this study. ${ }^{386}$ The in-person discussions (and two by telephone) aimed to uncover where executive branch service fits into the hierarchy of preferred options available to RSOs after they leave the military. They also inform understandings of RSO perceptions of the incentives and disincentives of executive branch service and in what way these factors may differ from those of other potential executive branch officials. While the officers perceived many different motivations for either accepting or dismissing executive branch opportunities, they all unanimously rejected the characterizations of RSOs implied in military colonization claims. Instead, they articulated perspectives and attitudes that reinforced the soldier-statesmen traits outlined in Chapter 2.

\footnotetext{
${ }^{385}$ The interviews, conducted over Winter, 2012-2013. The group of RSOs included a former one-star, six former two-star officers and six former four-star officers, representing each of the armed services except the Marine Corps. Of the thirteen officers, one 2-star currently serves in an SES position, one was a former SES official in DOD, five were former PAS appointees, and six of the officers had not served in the executive branch. The interviews followed a somewhat unstructured format which allowed the RSOs the flexibility to reflect on their own experiences as well as broader themes in civil-military relations. Three of the officers requested their comments only be used as background, and other requested not be quoted directly. Furthermore, to encourage a free discussion, I agreed to not attribute anecdotes to particular individuals when they included negative comments or perceptions of other RSOs.

${ }^{386}$ The oral history projects included those conducted by the Miller Center Presidential Oral History Project, http://millercenter.org/oralhistory, and the Brookings Institution's NSC Oral History Roundtables Project, http://www.brookings.edu/about/projects/archive/nsc/oralhistories.
} 


\section{RSO Self-Identified Categories}

Throughout the interviews the RSOs emphasized that significant distinctions must be made within the group of their fellow senior officers that eventually serve in the executive branch. To best capture these differences, it is helpful to consolidate their various depictions into three broad categories: political, quid pro quo, and technical expert RSOs. Each of these categories conjures up different considerations with respect to civil-military relations and the alternative patterns depicted in the RSO-executive branch relationship framework.

Before specifying each category, two considerations first require mention because they significantly color subsequent interview responses. The first relates to the former military rank of an executive branch RSO within the G/FO structure. All the officers interviewed, four-stars and one-stars alike, emphasized that when differentiating types of executive branch RSOs, it was critical to distinguish between the upper and lower two General/Field Officer (G/FO) ranks. While all G/FOs hold significant responsibilities in the military, it is the three and four-star officers that routinely interact with Congress, senior executive branch officials, and the American media. As we'll see, the few former senior officers that expressed reservations about RSO participation in the executive branch primarily focused their concerns on three and four-star appointments and not the lower one and two-star officers. The rank factor 
also strongly influences the incentives and disincentives presented by executive branch service.

A second overarching consideration that became readily apparent during the interviews relates to the exclusiveness of the RSO profession: these officers comprise an amazingly small and insular fraternity. Especially in the case of the four-star interviewees, they all professed close personal and/or professional interaction with each of the most publically recognizable officers of the last two decades including Colin Powell, James Jones, and David Petraeus and spoke of them with a notable familiarity. In numerous cases, this familiarity extended even beyond the relationship between fellow G/FOs but also reflected close attachments among their respective spouses and family members. If this feature of RSOs excites the attention of colonization purveyors, on the surface it appears understandable.

Returning to the task of categorizing the interviewee depictions of RSO executive branch officials, the first in the typology can be labeled the Political RSO. This category contains those few senior military leaders that transition to the highest profile and publically recognized executive branch positions. The interviewees agreed that while on active-duty some officers do develop reputations among their fellow officers as political generals or admirals. They suggested, however, that an important distinction be made among G/FOs perceived as politically ambitious and those deemed political because they possessed unique "instincts" and a keen understanding of institutional politics. An individual G/FO could of course manifest both of these political elements; 
however, the RSOs I interviewed expressed confidence that the internal organizational norms and considerations of the G/FO promotion process dissuaded and typically thwarted the rise to three and four-star ranks for those who demonstrated overt political ambition.

The confidence these RSOs displayed in the in-house policing mechanisms for detecting and impeding the politically ambitious invites the question: how do we then explain highly political post-Cold War figures like Colin Powell, Wesley Clark, James Jones, or David Petraeus? The RSOs acknowledged that these well-known officers present unique cases and agreed that these figures indeed were political generals in many respects both while on active duty and in retirement. They explained that these officers each followed irregular career development paths that kept them outside the operational, and at times the institutional military for significant portions of their formative professional years. Two of the most prominent post-Cold War executive branch RSOs, Colin Powell and James Jones, also spent significant portions of their careers in positions that diverted them from the typical operational and leadership path followed by most senior G/FOs. Powell served as an OMB fellow, military assistant to the Secretary of Defense, deputy national security advisor, and then national security advisor all while on active duty. These positions enabled him to make highly influential political connections with senior executive branch officials as well as congressional leaders and staffers, but the positions also complicated Powell's career progression in the Army. Powell skipped division command, which many Army officers traditionally recognize as the ultimate warrior position for any Army general officer. Powell instead 
moved directly to command a Corps, noting in his autobiography that his irregular career path to this position created some resentment among his fellow senior officers. $^{387}$

Former Marine general James Jones, Obama's first national security advisor, also spent considerable time throughout his military career in positions where he was directly connected with political actors. Jones served as the Marine's Senate legislative liaison officer, and, like Powell, as the military assistant to the Secretary of Defense. The liaison position put him in daily contact with congressional members and their staffs as well as DOD civilian appointees. Like Powell, these career track diversions resulted in Jones bypassing levels of command in the Marine Corps. An RSO who personally knew Jones well claimed that Jones remained highly conscious of potential resentment among fellow Marine Corps elites because of his irregular command progression. However, the RSO noted that Jones' strong overall reputation as an officer of enormous character mitigated its salience. ${ }^{388}$

Although Haig cannot be considered a post-Cold War RSO, the familiarity one RSO had with the former Secretary of State provided a fortuitous opportunity to contrast perceptions of Powell and Jones with an RSO that often is portrayed as emblematic of the institutional antagonist RSO. The interview depiction of Haig provided by this RSO coincides with popular accounts of the infamous general's personality which reinforces that he indeed exemplified some of the negative

\footnotetext{
387 Powell and Persico, My American Journey, 307.

${ }^{388}$ Telephone interview with former Air Force four-star general, 8 February 2013
} 
dimensions associated with RSO traits. Unlike Powell and Jones, Haig defied the image of transcendent politics characterization and was well ensconced in Republican circles even before joining the Reagan administration. The RSO who attested that he knew both Haig and Powell noted that while their careers featured similar exposures to executive branch, and specifically White House politics, they had quite different outlooks toward the positions. The RSO described Haig as exemplifying "vaulting ambition," whereas he viewed Powell's efforts as motivated primarily by an ethos of selfless service and a soldiers obedience to serve where directed. Powell therefore remained well respected among his peers despite his non-traditional and political career track and easily transitioned back to the Pentagon when he left the White House. The RSO's comparison of Haig and Powell and how they were viewed by their fellow G/FOs suggests that executive branch RSOs individually hold very different relationships with their Pentagon brethren. Their RSO status doesn't necessarily equate to comity as evidenced by a comment from the RSO who knew and served with both former generals: "[w]e are not going to see another Colin Powell anytime in the near future and I hope to hell we don't have to put up with another Haig." ${ }^{389}$

While the RSOs I interviewed acknowledged that Powell and Jones were undeniably political generals, they emphasized that this label too easily risked misrepresenting their service and incorrectly emphasized the civil-military antagonism connotations. An RSO who claimed a close relationship to both Powell and Jones explained that their regular interactions with political actors along with their engaging

${ }^{389}$ Personal interview with former Army four-star general, 16 January 2013 
and professional demeanors imbued them with a political "suaveness" and awareness that made them highly trusted and sought after by senior executive branch officials and congressional leaders. An RSO who served with Powell explained that "...there was a lot of pressure from the White House sucking him in to this business." ${ }^{390}$ A former four-star described that G/FOs with career paths like Jones and Powell get associated with particular party labels simply because obligatory military assignments force them into contact with political appointees in an administration. He further noted that Republican officials held a degree of suspicion about the former Marine because of the Democratic contacts he had made while an assistant to the Secretary of Defense during the Clinton Administration. ${ }^{391}$ Suspicions notwithstanding, although Jones expressed no partisan affiliation he was still courted by both parties for senior administration posts during the 2008 campaign. $^{392}$

In his oral history testimony on the Bush 41 administration, Admiral David Jeremiah, former Vice-Chairman of the JCS, commented on the tendency for G/FOs to perhaps unfairly get assigned the partisan label of the administrations they served. Jeremiah perceived this type of suspicion as a particularly acute issue during the BushClinton transition. ${ }^{393} \mathrm{G} /$ FOs that had worked closely with the Bush 41 administration in the course of their assigned duties, Jeremiah claimed, were immediately suspect after the Clinton transition. Jeremiah's observations reinforce that partisan labels often attached to certain political generals likely reflect the timing of an officer's assignments

\footnotetext{
${ }^{390}$ Personal interview with former Army four-star general 16 January 2013

${ }^{391}$ King Jr., "The Courting of General Jones - WSJ.com."

392 Ibid.

393 Jeremiah, Miller Center Presidential Oral History Project.
} 
and the incumbent administration and not necessarily their own partisan preferences if they even have one at all.

In sum, the RSOs interviewed did recognize a distinct form of political RSO, but they overwhelmingly saw the most recent members of the category, Jones and Powell, as resembling the antithesis to any diabolical military colonization characterization. Their accounts attest that each of these figures possessed unique personal and professional talents that they used to facilitate better cross-branch relationships and not simply narrow military influence or personal political ambitions. Rather than viewing them as burrowed advocates for the institutional military, they resembled selfless public officials, molded throughout their careers by direct interaction with civilian elites and the democratic process, and ultimately they served as vital links for building trust across institutions. The depictions of these post-Cold War RSOs offered by the interviewed officers align well with the soldier-statesman characteristics. Their prestige, institutional mindedness, and image of transcendent politics enabled these figures to perhaps temper some of the impulses of partisanship and military influence in the particular administrations they served. In this way they reflected the credible countervailing and trusted agent labels.

"Quid pro quo" RSOs comprise the second descriptive category that took shape during the interviews. Although quid pro quo transactions often are often difficult to fully confirm, RSOs in this category putatively receive presidential appointments as a reward for publically endorsing a candidate, an exchange overwhelmingly condemned 
by the officers interviewed. Clinton's appointment of former chairman of the Joint

Chiefs of Staff, Admiral William Crowe, as ambassador to the United Kingdom is routinely cited as emblematic of this category. One former four-star described Crowe's apparent deal as "despicable...a case of a president buying himself some generals." 394

In October 1992, Crowe and twenty-one other RSOs publicly endorsed candidate Clinton for the presidency and in doing so unabashedly emphasized their former military rank. According to some civil-military scholars, Crowe's deviated from professional norms and commenced the post-Cold War trend in senior officer endorsements during presidential campaigns. ${ }^{395}$ Crowe justified his support by claiming he wanted to: “...explode[d] the myth...that nobody in the American military was a Democrat...." ${ }^{396}$ While Crowe's action gained the most attention, other RSOs also apparently benefited from quid pro quo arrangements with the Clinton administration. ${ }^{397}$ Two RSOs that similarly supported Clinton received executive branch nominations later in the administration: Clinton appointed retired Army General Fred Woerner to the American Battlefield Monuments Commission, ${ }^{398}$ and retired Vice-Admiral Albert Herberger as

\footnotetext{
${ }^{394}$ Personal interview with former Army four-star, 16 January 2013

${ }^{395}$ Golby, Dropp, and Feaver, Military Campaigns: Veterans' Endorsements and Presidential Elections; Bacevich and Kohn, "Grand Army of the Republicans: Has the U.S. Military Become a Partisan Force?". ${ }^{396}$ William J. Crowe, The Line of Fire : from Washington to the Gulf, the Politics and Battles of the New Military (New York: Simon \& Schuster, 1993), 343.

${ }^{397}$ White House: Office of the Press Secretary, "President Announces Appointment of Fred F. Woerner and F. Haydn Williams as Members of the American Battle Monuments Commission," May 27, 1994, http://clinton6.nara.gov/1994/05/1994-05-27-president-names-members-to-american-battlecommission.html.

${ }^{398}$ Woerner's endorsement must also be examined as potentially a case of "retaliation" against the Bush administration. Woerner was the South Com CINC but was removed just prior to the Panama invasion in 1989. According to Brent Scowcroft's Miller Center Oral History testimony, the administration expressed concern early in the planning process that perhaps Woerner, whose headquarters were in Panama, had perhaps become too close to local leaders; the administration therefore was not confident in Woerner's ability to objectively execute the potential invasion. Although not related to an executive branch
} 
Administrator of the Maritime Administration. Another RSO and Clinton supporter, Vice-Admiral Richard Truly, however, ostensibly defies the quid pro quo pattern. Bush 41 appointed Truly as the NASA administrator only to later see him endorse the Democrat candidate in the following election. Truly's actions demonstrate that an executive branch appointment does not always ensure future political support. ${ }^{399}$ Twotime Bush 43 PAS appointee Admiral Frank Loy similarly endorsed Obama during his first presidential campaign as did Colin Powell.

Two Obama ambassador appointments resemble quid pro quo relationships with RSOs. Major General (retired) Scot Gration endorsed Obama and subsequently served as an advisor for his 2008 campaign. The president later named him Ambassador to Kenya, a posting that had elevated significance because of Obama's direct familial connection to the country. Another Obama sponsor in 2007, RSO James Smith, a former Air Force one-star, was named the Ambassador to Saudi Arabia following the 2008 election. Neither of these former generals was well known publically, but in an election where military issues and military service were front and center, the Obama team likely valued any perceived connections to the armed forces. ${ }^{400}$

As mentioned earlier, the RSOs interviewed saw quid pro quo transactions as directly at odds with traditional codes of military professionalism in the American officer

appointment, the "retaliation" hypothesis gains additional support in the case of another officer that joined Crowe's same endorsement. Air Force RSO Michael Dugan had been removed by the Bush Administration as the service's Chief of Staff just prior to Desert Storm.

${ }^{399}$ National Public Telecomputing Network, "21 Military Leaders Endorse Bill Clinton for President; Endorse a Strong Defense and A Strong Economy," October 12, 1992, http://stuff.mit.edu:8001/afs/net/user/tytso/usenet/nptn/campaign92/dems/76.

400 "Barack Obama: Press Release - Over 70 Foreign Policy Experts Announce Endorsement of Barack Obama for President," December 19, 2007, http://www.presidency.ucsb.edu/ws/index.php?pid=91967. 
corps. RSOs that pursue, let alone accept an executive branch appointment via a quid pro quo agreement prostitute the very attributes that undergird the public trust and prestige they are afforded. Rather than using the prestige, institutional mindedness, and image of transcendent politics attached to RSOs as a whole, these traits are ostensibly sacrificed for short-term personal rewards. Despite the perceived sinister nature of this category of RSOs, however, they appear relatively anomalous. The most apparent examples amount to only a few ambassadorship appointments and to lower level appointments to federal commissions. Nevertheless, if increased numbers of executive branch RSO appointments begin to resemble this category, military colonization concerns would indeed gain added salience. The nearly universal condemnation of the practice among the interviewed RSOs, however, suggests that the profession code of former senior officers themselves serves as the predominant bulwark against the expansion of quid pro quo appointments.

The Political and Quid pro quo categories capture some dimensions of the RSOexecutive branch relationship, but together they represent only a small portion of the appointments. The third grouping, the Technical Expert category, encompasses the vast majority of RSO appointments. Like civilian professionals from the private or public sector, many RSOs desire to serve at the organizational pinnacle of their respective technical field. Depending on the profession, the top corresponding positions may reside in academia, corporate America, or other private sector organizations. Not surprisingly, the federal government also holds sole possession of the top posts for certain professions. For example, skills and expertise related to intelligence, nuclear 
energy, and many transportation functions are centralized in civilian administrations, but the core technical competencies are often predominantly developed in the military. Highlighting this frequent connection, an interviewed RSO who oversees the Customs and Border Protection Agencies fleet of planes and ships asked rhetorically, "[w]here else do you get someone with my qualifications for a job like this?" ${ }^{401}$ This observation may appear commonsensical, but with respect to colonization claims it merits further scrutiny. If RSO executive branch service relates more closely to purely technical expertise and not generalized leadership competencies then an increased number of RSOs in executive branch positions ostensibly presents fewer of the risks envisioned in colonization claims. RSOs may simply view executive branch service as an opportunity to practice their technical craft at the highest level and may consider the political aspects irrelevant to their own professional aspirations.

Two Bush 43 appointees in the interview pool, one a former Air Force two-star, and another, a former Army one-star, capture the distinguishing features of the Technical Expert category. Bush appointed the former to an Executive Schedule (ES) level-four position in the Office of the Director of National Intelligence (ODNI), the first incumbent to the position created in the wake of 9-11. The former two-star attributed his appointment primarily to his technical expertise and his understanding of the existing intelligence structure that he had gained over his 30 plus years as an intelligence officer. The RSO professed that prior to his nomination to the newly created ODNI position he had held little interest in any existing assignments in the civilian

${ }^{401}$ Personal interview with a former Air Force two-star general, 1 November 2012, Washington D.C. 
intelligence community. The RSO envisaged the pre-ODNI civilian agencies as entrenched in cumbersome and apathetic bureaucratic procedures, and he claimed he likely would have declined a nomination to any of them. However, he viewed the ODNI position as an opportunity to mold a new intelligence organization and set the foundation for its future success. He saw it as an enticing professional and personal challenge. The former general cited similar professional motivations among other RSOs that accepted civilian executive branch positions in DHS and ODNI following the 2005 reorganization. The RSO predicted, however, that as these organizations matured and the perceived opportunities to significantly shape them diminished, RSOs will no longer find these organizations particularly attractive. ${ }^{402}$

Perhaps surprisingly, this ODNI appointee attributed the perceived leadership competencies often ascribed to G/FOs as minor influences in his selection. Throughout the nomination process, which included 23 interviews and intrusive investigations into his finances, family, and social relationships, all of which were highlighted were significant disincentives, the RSO recalled that at no point did anyone discuss his leadership qualifications or even inquire why he wanted the position. Based on his confirmation experience, he concluded that two questions weighed disproportionately in PAS appointments: 1) would the nominee loyally serve the president, and 2) was the nominee confirmable. In his view, his former military status, partisan affiliation, and personal leadership characteristics played a minor role at best during the confirmation process.

${ }^{402}$ Personal interview with former Air Force two-star, 12 December 2012, Washington D.C. 
An Army one-star's executive branch appointment also reflects characteristics of the Technical Expertise category, and he too professed that he accepted the position in large part because it represented the apogee of his technical field. This RSO, a former officer in the Army Corps of Engineers, served as deputy administrator, and later as Administrator, of the Federal Highway Administration (FHA), an ES level-two position under Bush 43. The officer attributed his appointment as Administrator primarily to his technical competencies, but more so to specific skills honed in his post-military career. Like the ODNI appointee previously discussed, this RSO viewed his former military status as only a minimal contributor to his appointment. He claimed that his willingness to accept the nomination, reflected his interest "... in delivering something that made a difference at a high-level." According to the former general, the opportunity to leverage public resources to accomplish significant engineering projects in the American transportation system eclipsed the private sector monetary incentives that he admittedly bypassed. He acknowledged the private sector's dominant role in creating the nation's infrastructure, but he noted that public officials ultimately prioritized projects, determined the locations of major works, and then found ways to fund them. It was these elements of public service that attracted him to the position.

The one-star Army officer advised that distinctions among executive departments should be made before examining the political nature of RSO appointments. For instance, he deemed the Transportation Department much less politicized than other organizations, commenting, "[t]here are no Republican bridges or Democratic bridges." As an indicator of the organization's "apolitical" nature, he 
pointed to his immediate boss in the Bush administration who was a Democrat:

Secretary of Transportation Normal Mineta. During his background investigation for the ES position, he recalled that he responded to questions related to political affiliation by noting that although his political outlook aligned most closely with the Republican Party, he did not consider himself part of either party and had never contributed or otherwise been involved in a political campaign or endorsed a candidate. He recalled that any investigator concerns over his tepid party commitment seemed to evaporate when he reminded them of his former military status and the active-duty restrictions on political involvement. In retrospect, the Army RSO said he did not know whether his former military status allayed investigator concerns because of a Republican partisan assumption about RSOs, or because the investigators viewed RSOs as truly non-partisan. In any case, he recalled no instances where senior political leaders pressured or even encouraged political appointees in the Department of Transportation to contribute on the political front, and he was never asked to highlight his RSO status for political reasons.

\section{Incentives and Disincentives of Executive Branch Service}

The categories of Political, Quid pro quo, and Technical Expert differentiate types of RSO-executive branch relationships, but they still only limited insight into why RSOs choose to serve in these positions. To address the why question, I asked the RSOs I interviewed to explain how potential opportunities to serve in the executive branch 
factored into their own post-military calculations. Of the group, only two professed that they actively considered executive branch service as a post-retirement option. ${ }^{403}$ More typical responses reflected the attitude that working for the executive branch, “...wasn't even on the radar." ${ }^{104}$ A former Air Force four-star responded even more pointedly: "I've got a pretty easy answer for you: it [executive service] was the very, very, very, very last option l'd consider. There isn't a position in the entire government l'd want. ${ }^{\prime 405}$ When further pressed as to why executive branch service apparently held such little appeal the responses showed more variance. Only two officers, however, cited traditional civil-military relations concerns as factors. One explained that while he did not view RSO executive branch service as a potential danger to civilian control of the military or a prelude to militarized national security policies, his concerns related primarily to the potential harmful effects the practice could have on the readiness and morale of the broader military. A recently retired Navy four-star, worried that if RSOs routinely transitioned to high-profile positions in the executive administration, junior officers and enlisted members would begin to speculate about the partisan motives and affiliations of their current senior officers. ${ }^{406}$ He feared such an environment could easily undermine the institutional military's trust in its senior uniformed leaders and their motives, and, as a consequence, diminish the traditional values upon which military service rests. If notions of Democrat generals or Republican admirals infiltrated the lower ranks of the military, the Navy RSO argued, then fundamental military values

\footnotetext{
${ }^{403}$ One Air Force Reserve RSO I interviewed had served as a DOD SES employee at the same time he held his 2-star reserve commission. Therefore, the question was therefore less relevant in his case.

${ }^{404}$ Telephone interview with former Air Force four-star general, 8 February 2013.

${ }^{405}$ Telephone interview with former Air Force four-star general, 7 March 2013.

${ }^{406}$ Interview with four-star admiral, former Commander, US Fleet Forces Command, November 26, 2012,.
} 
such as selflessness, teamwork, and apolitical service to the state would become increasingly difficult to inculcate and protect at the lower levels. In his view, officers entering the elite G/FO ranks, especially at the three and four-star levels, assume positions of public trust that entail life-long professional responsibilities. Upon retirement, the former admiral believed that self-imposed restraint from public displays of partisan politics was a civic-republican duty of RSOs. He professed that most RSOs do hold a deep commitment to apolitical service to the country, but he also believed that executive branch appointments inherently convey the perception of "declaring one's party credentials," a perception simply too difficult to overcome.

The admiral opposed any statutory prohibitions against RSOs serving in the executive branch, but he argued that norms discouraging this option ought to be thoroughly inculcated early in an officer's career. Although confident that active-duty officers closely adhered to a code of apolitical service, the Navy RSO suggested that the post-retirement expectations received too little attention in professional military education programs and he deemed it unfortunate that, in his experience, active senior officers rarely discussed the issue among themselves. His comments regarding those that RSOs that had served in the executive branch predominantly indicated that they exhibited the soldier-statesman outlined in each category. In the end, however, the retired admiral believed that a RSO's best mode of demonstrating true civic-republican virtue was to restrain from any executive branch service. Interestingly, he consistently expressed great admiration for General George Marshall during his interview although his own views on executive branch service would ostensibly exclude any such figure 
from these positions. When asked about this apparent paradox, he simply replied, "[t]here will never be another George Marshall..."; a refrain agreed with by more than a few of the RSOs interviewed.

An Army four-star RSO also expressed reluctance about RSO participation in executive-branch politics, but he articulated more traditional views related to a distinct separation between military and civilian spheres. ${ }^{407}$ The RSO noted that his views had significantly changed over the course of his career and were heavily influenced by his experiences as a senior leader in the United States Southern Command in the mid1980s. ${ }^{408}$ The RSO explained that as the military commander responsible for US forces and operations in Central and South America, "I spent a lot of my career trying to persuade foreign generals to get themselves the hell out of politics...a military career is not very good preparation for leading any country anywhere...we're [i.e. military officers] not very well prepared by our experiences to do that...nothing in military experience qualifies one to be good at graft!" After continually espousing to these officers the necessity of apolitical military service in their own democratic governments, he eventually considered it hypocritical to consider such options himself. The RSO noted that he refused an ambassador position in Asia and a presidentially appointed position in the State Department after his retirement in large part because of his civilmilitary outlook.

\footnotetext{
407 Personal interview with former Army four-star, 16 January 2013, Crozet Virginia.

408 During the 1980's US Southern Command (USSOUTHCOM) was headquartered in Panama. In 1997 USSOUTHCOM headquarters moved to Miami. The command's area of responsibility includes all of Latin America south of Mexico, the coastal waters of central and South America and the Caribbean Sea.
} 
The RSOs interviewed were also asked about the relative significance of activeduty officers versus RSOs filling executive branch positions and the associated civilmilitary implications. A former ODNI official described that in his own nomination and confirmation process, practical administrative concerns dictated that he retire before accepting an executive branch PAS position, not concerns related to civil-military dynamics or perceptions of colonization and militarization. Reflecting on his own nomination experience, the RSO explained that administration officials and Congress originally envisaged that an active-duty three-star officer would fill the newly created ODNI position. The position therefore afforded this former two-star the opportunity to remain on active duty and earn a promotion to the three-star rank that accompanied the new posting. After accepting the nomination, however, the RSO explained that administration officials changed course and requested that he retire from the military as a two-star officer before his Senate confirmation hearings. The request for him to retire, however, did not represent an effort to mitigate perceptions of military colonization or a militarizing of the intelligence community. Instead, the administration officials managing his PAS appointment simply wanted to avoid the delays and extra administrative requirements associated with confirmation hearings in two separate Senate committees. If the former G/FO remained on active duty, the move to ODNI required Senate hearings not only in ODNI's oversight committee, the Select Committee on Intelligence, but also in the Armed Services Committee since the nomination entailed a promotion to three-star general. The G/FO offered this anecdote to highlight that what outsiders may perceive as a civil-military relations issue, or an effort to impede 
military influence in the civilian intelligence community, instead simply represented a case of practical administrative expediency. In his recollection, civil-military issues related to his nomination never arose in the Pentagon or among civilian officials.

In addition to the civil-military concerns expressed above, the RSOs offered a wide variety of other factors that they claimed influenced their attitudes toward executive branch service. A former Air Force two-star general, and current SES official, offered a rudimentary but nonetheless useful framework for categorizing these factors. ${ }^{409}$ He posited that the decision matrix of RSOs could be boiled down into three main considerations: where do I want to live, how much money do I really want to make, and do I want to remain within a professional culture similar to that experienced during my military career. While this framework failed to encompass all the interview responses, it nonetheless provides a basic structure to consider how the RSOs perceive the incentives and disincentives of executive service.

The first factor, retirement location, hardly represents a unique concern to RSOs, and therefore its explanatory value is tempting to dismiss. Nonetheless, the RSOs I interviewed so consistently mentioned the importance of this factor that it demands some attention. For the most part, RSO concerns about retirement location mirrored those commonly expressed by nearly all retiring professionals in America. Proximity to family or access to particular health facilities, all were listed as factors during the interviews. Perhaps somewhat unique to RSOs, however, retirement offered the first opportunity in their adult lives to choose where to live. Geographic mobility pertains to

\footnotetext{
${ }^{409}$ Personal interview with a former Air Force two-star general, 1 November 2012, Washington D.C.
} 
many professionals, but few career paths match the frequency, diversity, unpredictability, and obligatory nature of relocations experienced by RSOs. Many in the interview group had moved over 20 times during their careers, and all but two had served long tours in overseas assignments, most multiple times. The itinerant nature of a military career weakens ties to any particular location, and after a 35 plus year career, the bonds to an original "home" have long sense dissolved. Furthermore, many former active-duty RSOs explained that during their careers it was understood that upon retirement, their spouses would have a disproportionate say in their final location choice. Since senior executive branch positions reside almost exclusively in Washington D.C., a location veto by a move-weary spouse obviously has the potential to eliminate some opportunities.

An Army four-star RSO admitted that family concerns related to location were the primary factors that dissuaded him from even considering a position in the executive branch. To illustrate the significance of this factor, the former general offered a personal and comical anecdote, but one he believed reflected experiences common to many RSOs. Well before the projected retirement date agreed upon with his wife, the four-star general purchased a small Virginia farm where the couple intended to pursue a life-long passion for wine-making. As the retirement date approached, the Chairman of the Joint Chiefs met with the RSO and convinced him that he, the Chairman, had no available options for filling a commander-in-chief (CINC) position in a major geographic command. The RSO said he felt duty-bound to accept the position and reluctantly delayed his retirement for two more years. When the RSO informed his wife, she was 
unhappy to say the least, and in her disappointment she purchased a large bell on which she inscribed the name of the new farm and the newly established retirement date. Every night after dinner during the unplanned assignment, his wife, without comment, rang the bell. The gesture reminded him that there was absolutely no executive position, private or federal, that could have been safely considered once the new date arrived.

Following retirement, and despite what he deemed as strong pressure from executive branch officials, this officer turned down an ambassadorship to Pakistan, and later a significant State Department ES appointment. He recalled that a senior figure in the Reagan administration eventually resorted to the mother of all pressure tactics in an attempt to persuade the RSO to accept the State position: the official insisted that "George Marshall would have never turned down such a request to serve his country." The RSO responded by noting his tremendous affection and affinity for General Marshall, but closed the conversation by telling his suitors, "with all due respect, General Marshall was not married to Mrs. xxxx!" Following our interview, the general directed my attention to the front of his farmhouse where a large inscribed bell is perched on pole.

Professing a distaste of Washington D.C. is arguably a prerequisite for nearly all senior executive branch officials and most of the interviewed RSOs appeared no different in this respect. All but one officer I interviewed had served at least one tour at the Pentagon or other D.C. location prior to retirement. The RSO that had not served in 
D.C. displayed both a sense of relief and even pride in his good fortune to have avoided any Washington assignment. The ethos of the military predictably elevates the commander "in the field" well above the bureaucratic military leader ensconced in the trappings of the nation's capital and this ethos appears to color perceptions of Washington that carry into retirement. Half of the officers interviewed said that living in D.C. presented a significant disincentive for executive service, one offering the comment, "I couldn't get out of that place fast enough." 410

The emphasis on a spouse veto card or a professed abhorrence of Washington may reflect a degree of tongue-in-cheek, but the frequency which these concerns arose shows that they are not insignificant factors. In an age where the average American relocates every five or so years, military careers may be much less unique in this respect than in the past. The relative predictability and finality of military retirement, however, allows RSOs to focus on a particular date and to begin contemplating and solidifying post-retirement alternatives well before the actual event. As a consequence, family promises are made and plans become much harder to dislodge once the date arrives even if other opportunities become available. Moreover, social and family ties that commonly entice many people to stay in given location upon retirement arguably prevail less in military families. The closest social contacts of RSOs also are likely to be fellow military members who are dispersed geographically which further loosens ties to any particular area. Grand civil-military relations theories notwithstanding, the

\footnotetext{
${ }^{410}$ Telephone interview with former Air Force Four-star, 7 March 2013.
} 
frequency with which location factors arose during the interviews serves as a reminder that in the end, very practical considerations often rule the day.

Continuing with the rudimentary typology outlined earlier, the RSOs routinely cited monetary considerations as a major disincentive to accepting an executive branch position. An Air Force four-star RSO suggested that the paltry financial incentives to serve in the executive branch explain $75 \%$ of the story as to why RSOs do not pursue such positions. ${ }^{411}$ The RSOs, in particular the four-star officers, unapologetically cited the enormous financial opportunities in corporate America, one bluntly stating that his net worth had "exploded" since his retirement. This officer estimated that among the four-stars he knew well, all of them earned between $\$ 500 \mathrm{~K}$ to $\$ 1$ million a year in their post-retirement activities.

Reinforcing the RSO assertions regarding monetary incentives, a recent Huntington Post report found that from 2009-2011, 76 out of 108, or $70 \%$ of retired three-and-four star officers took positions with defense contractors upon leaving the military. ${ }^{412}$ A 2010 Boston Globe investigation published similar findings, showcasing the enormous compensation received by RSOs, in some cases only days or weeks after they officially retired. ${ }^{413}$ One officer interviewed acknowledged that some RSOs “... just want the opportunity to make some money," but further explained that although defense contractors do pay well, the window of opportunity is rather narrow and fleeting. ${ }^{414} \mathrm{~A}$

\footnotetext{
${ }^{411}$ Telephone interview with a former Air Force four-star general, 7 March 2013.

412 Johnson, "Report: 70 Percent of Retired Generals Took Jobs With Defense Contractors or Consultants."

${ }^{413}$ Vanden Brook, Dilanian, and Locker, "Retired Military Officers Cash in as Well-Paid Consultants."

${ }^{414}$ Personal interview with former Air Force two-star, 6 September 2012, Charlottesville, Virginia.
} 
consensus among the RSO group suggested that their professional connections within the Pentagon and familiarity with current procurement processes and procedures represented what the large contractors truly desired, not necessarily their purported leadership skills or technical competencies. One former two-star explained that this aspect of post-retirement corporate employment actually spurred him to quickly leave the private sector and return to government service as a PAS appointee. The RSO confessed that he felt he was simply "selling Tupperware to my friends" as a defense contractor. Despite the handsome compensation, he found his private sector experience tremendously unsatisfying professionally. ${ }^{415}$

In addition to recognizing that much of their corporate value rested on professional contacts, they also acknowledged that this attribute of "access" had a limited shelf-life. The officers generally agreed that due to the normal progression of the retirement and/or promotion process, in most cases RSOs can expect to have the desired level of professional contacts within the Pentagon and the insider technical knowledge for only three to four years following retirement possibly even less. Additionally, the political winds and electoral cycles in Washington alter the relationship patterns and professional contacts with the civilian leaders they worked with while on active-duty. Therefore, if RSOs aspire to gain financially from their status with defense contractors, they must strike why the iron is hot. Since many corporations set mandatory retirement ages and often require at least 5 years of employment for senior

\footnotetext{
415 Personal interview with Major General William Navas (USNR-ret), former assistant secretary of the Navy and Director, National Security Professional Development Program Integration Office.
} 
executives before they become "vested," delaying entry into the corporate world for 2-3 years to fill an executive branch position easily endangers future opportunities. ${ }^{416}$

Fortuitously for this study, one former Air Force four-star interviewed was a central figure in the 2010 Boston Globe investigative report, and he provided an inside perspective on the financial incentives RSOs face at retirement and how these incentives impact their relationship to the executive branch. The Globe article noted by name the impressive compensation received by this four-star, but more controversially, the report questioned the apparent conflicts of interest his activities entailed. The officer served on the corporate boards of multiple defense contractors, and served concurrently as a paid "mentor" to active-duty officers participating in military war game simulations. The Globe article acknowledged that nothing was technically illegal about the arrangements, but it highlighted potential ethical implications. The defense contractors that supply RSO mentors for the war game exercises routinely have significant financial stakes in understanding the simulated outcomes as well as the technical capabilities senior leaders want for future operations.

During his interview, the RSO unapologetically and emphatically emphasized the vital importance of RSO mentors to the military and the nation. He argued that past high-visibility indiscretions in defense contracting and procurement have led to an overzealous legal environment where significant walls exist between those who design, build and sell military hardware, and those who buy and operate the equipment and

\footnotetext{
${ }^{416}$ I owe thanks to a former Navy two-star admiral that brought the mandatory corporate retirement and vesting factors to my attention. 26 March 2013, Washington D.C.
} 
determine future military requirements. He acknowledged some statutory barriers to prevent financial malfeasance were necessary, but he argued the current barriers unnecessarily undermine valuable interaction between contractors and military personnel. In his view, these obstacles prevent the military from effectively articulating future requirements and performance expectations. Likewise, the barriers impede the contractor's ability to convey technical limitations in meeting these needs back to the military. This situation leads to a disjuncture between technical expectations and capabilities.

According to this RSO, prohibitions on the direct interaction between military users and defense contractors create an enormous trust differential between actors which leads military officers to develop highly jaded views of corporate America. The trust gap ultimately leads to cost overruns, and under-performing equipment that simply doesn't meet military needs. The retired general suggested that RSOs who accept executive branch appointments immediately after retirement potentially carry this distrust of corporate America into their official positions. He described RSOs' lack of corporate knowledge as a significant "blind spot," and suggested that administration officials should encourage corporate experience as a prerequisite to considering an RSO for an executive branch appointment. The officer acknowledged the negative perceptions resulting from the financial incentives, but emphasized that his experience in corporate America uniquely allowed him and other officers to recognize the mutual interests of both the government and the private sector. In sum, the general suggested that RSOs can serve as trusted agents for both sides of the military-corporate 
relationship and they can become critical linking mechanisms when they later serve as executive branch appointees.

The perspective outlined above that argues that RSOs can enhance effective military and corporate interaction opens up a myriad of other issues related to the influence of RSOs on the executive branch and in particular national security policy. The most memorable words of Eisenhower's farewell address loom large when considering the corporate-military liaison relationship discussed by the RSO in the previous paragraph. Eisenhower advised: "In the councils of government we must guard against the acquisition of unwarranted influence, whether sought or unsought, by the militaryindustrial complex. The potential for the disastrous rise of misplaced power exists and will persist." ${ }^{417}$ The interview discussion with the RSO ensconced in the militaryindustrial web highlights, however, that former senior officers may temper some of the potential harmful elements in this relationship. RSOs may lend their public prestige, institutional mindedness, and image of transcendent politics to provide a credible and influential conduit to ensure mutual trust and restraint in the military-industrial complex relationship. The Boston Globe report does, however, suggest that the risk of corporate proxies potentially presents an insidious and credible problem for healthy RSO-executive branch relationships.

A former four-star admiral offered an alternative spin on how RSOs perceive financially lucrative post-retirement opportunities. The officer suggested that RSOs

\footnotetext{
${ }^{417}$ Dwight D. Eisenhower, “Farewell Address” (Washington D.C., January 17, 1961),
} http://archive.org/stream/publicpapersofth015184mbp\#page/n1/mode/2up. 
often view corporate opportunities as "delayed" compensation for their long years at government salary levels. He explained that once officers reach the most senior ranks, pay becomes capped at a level equivalent to ES level-two civilian positions. This means that despite steadily increasing rank and responsibility, G/FOs potentially serve their last 5-10 years without seeing relative increases in pay. This pay "freeze" occurs for the topranking officers while, at least over the last decade, lower ranking military members continued to see regular pay increases. This characteristic of the pay system "compresses" the pay incentive associated with rank at the G/FO level, and effectively reduces pay in real terms. Lucrative post-retirement jobs therefore represent "delayed" compensation for the decline in real wages. For this officer and others, post-retirement financial opportunities provided a way to thank their families for the burdens endured over long careers, in his particular case nearly 40 years. In this officer's mind, his family had allowed him to pursue the career he wanted, endured the hardships associated with it, and thus he said, “...l'd like to be able to leave them something as a thank you." ${ }^{418}$

Not every member of the RSO group shared outlooks similar to the four-star admirals on the monetary incentives. A retired Air Force major general suggested that many G/FOs have an inflated sense of what level of pay they should command upon retirement. ${ }^{419}$ In his view, the notion that active military officers are not compensated at a level commensurate to their worth hints of institutional arrogance, and it also reflects

\footnotetext{
${ }^{418}$ Personal interview with former Navy Admiral, 26 November 2012, Charlottesville, Virginia

${ }^{419}$ Personal interview with former Air Force two-star general, 1 November 2012, Washington D.C.
} 
ignorance on the level of professional competition and pay scales in the private sector. Reflecting on his extensive experience in the SES, the former two-star officer suggested that the ebbs and flows in national employment trends affected RSOs just as all other job seekers; when high-paying positions evaporated in the private sector, RSOs exhibited no principled objection to seeking executive branch positions. Following his military retirement, this officer worked as a NASA career SES official in the Space Station and Space Shuttle program before moving to a career SES position in DHS's Custom and Border Protection's (CBP) Office of Air and Marine. The officer's conclusions about the relative importance of financial considerations and RSO ignorance of the private sector grew from his own experiences in hiring fellow retired officers into subordinate SES positions. He explained that prior to 2008 few RSOs applied for open SES positions in his agency. Following the 2008 financial meltdown, however, 65 and 85 RSOs applied for two different deputy positions. From his vantage point, RSOs discarded any professed aversions to executive branch service once the large corporate opportunities disappeared.

A final element related to RSO financial considerations that arose during the interviews was offered by a former Navy two-star admiral. For this RSO, the opportunity costs of foregoing corporate positions were not the primary monetary factors associated with executive serve, but rather the financial burden imposed by the long nomination process. ${ }^{420}$ As a nominee for a senior Department of Homeland Security position, administration officials advised him to have no contact with any private

${ }^{420}$ Interview with former Navy two-star admiral, 26 March 2013, Washington D.C. 
interests that had even a remote relationship to potential DHS contracts. This restriction effectively eliminated his ability to use his valuable technical expertise to earn any type of financial remuneration during his uncharacteristically brief seven month confirmation process. The former officer claimed that he accepted the financial burden of the nomination process because he felt he had a calling for public service, but noted that the required sacrifice likely represented a significant disincentive for many RSOs.

The financial factors discussed by the RSOs, overall, highlighted strong disincentives for executive branch service. Those who had served in the executive branch all claimed to have paid a significant financial opportunity cost for doing so. In light of the RSO interview comments, mapping the financial element onto the RSOexecutive branch categories serves to reinforce the soldier-statesman dimensions outlined in the framework. RSOs principally motivated by monetary incentives find far better opportunities than executive branch service, but those who devalue financial concerns put themselves in a stronger position to serve as credible-countervailing figures, independent experts or trusted envoys.

A third factor that helps explain why RSOs choose executive branch service relates to the purported cultural disparity between military and civilian executive branch organizations. The majority of the RSO group shared a consensus that significant cultural differences exist between the civilian executive branch and the organizational military, differences that dissuaded many officers from pursuing positions in the former. 
Many of their comments generally aligned with stereotypical depictions of the bureaucracy that characterize it as a lethargic, cumbersome juggernaut populated by entrenched bureaucrats content just to muddle along. The RSOs contrasted this perception with their former military organizations and simply envisaged executive service as laden with frustration, stagnancy, and ultimately professional disappointment. One RSO imagined that, “...the emotional return of executive branch service could never even come close to matching that experienced in the military." ${ }^{421}$ When asked to rank potential post-retirement options, this officer placed executive branch service at or near the bottom, in large part because of this cultural disparity.

The former ODNI appointee discussed earlier in the chapter also expressed disappointment as he described his first-hand experience with bureaucratic culture. ${ }^{422}$ The former PAS appointee described that one-third of his civilian ODNI staff chose to transfer to positions in other governmental agencies rather than relocate with the nascent organization to a new building 20-25 minutes away. The former general admitted that their response stunned him, but after reflecting on his total experience in the appointed position, he now viewed his earlier expectations of employee loyalty as somewhat naïve. The mass exodus surprised him because the new organization offered opportunities for many individuals to have an enduring and significant influence on the long-term success of the reorganized intelligence community. In his mind, the exodus highlighted a lack of organizational loyalty to a vital mission in post-9/11 executive

\footnotetext{
${ }^{421}$ Personal interview with former Navy four-star, 26 November 2012, Charlottesville, Virginia

${ }^{422}$ Personal interview with former Air Force two-star and DNI appointee, 12 December 2012, Washington D.C.
} 
government and a weak commitment to the ideals of public service that he perceived in the military.

When I presented the anecdote above to other RSOs who had served in the executive branch, they claimed little surprise, but some remarked that the civil-military culture divide was often overstated. A Navy two-star reserve RSO and former PAS appointee to the Federal Maritime Commission suggested that former regular officers tended to perceive cultural disparities more readily than reserve officers. ${ }^{423}$ In his experience, changes in the work environment and the overt ambition among many political appointees often shocked the professional sensibilities of RSOs that entered the executive branch. Even basic tenets of moral behavior such as honesty and loyalty toward both subordinates and supervisors often appear woefully absent in some cases. The former admiral explained, however, that reserve officers, or regular officers who had spent significant time interacting with civilian agencies while in the military, better understood the motivations and career incentives of the political appointees and the practical dimensions of their behavior. In contrast to the military, career paths among civilian executive branch officials are more irregular, more flexible, and less predictable. As a consequence, civilian officials have the agency to maneuver and shape their desired career path in ways viewed foreign or even subversive to RSOs. What may appear as disloyalty in the hierarchical military may be lauded as efficient and practical innovation in accomplishing bureaucratic goals and professional advancement in the civilian bureaucracy. Moreover, a former Air Force four-star suggested that pinning aversions

${ }^{423}$ Personal interview with USN Rear-Admiral, 12 September 2012, Alexandria, Virginia. 
to executive branch positions on cultural differences only served as a cover for RSOs that were unable to adapt to the different needs of subordinates in civilian organizations. ${ }^{424}$ Although he hadn't served in the civilian executive branch himself, his experiences in working with civilian agencies during his military career led him to see similar leadership challenges in both military and civilian organizations. This RSO doubted the assertion that many RSOs avoided executive service primarily because they perceived a civilian workforce comprised of sluggards.

The RSOs also consistently cited cultural differences related to the supervisorsubordinate relationship and the prevalence of "hidden power" in civilian organizations. RSOs with previous executive branch experience routinely noted significant disparities in how executive branch employees and military personnel interpreted supervisory directives and claimed that fellow senior officers often found it difficult to adapt to these differences. The former two-star and current Customs and Border Protection official discussed earlier explained that as a general officer in the military, subordinates often disagreed with his directives, but he never doubted that these same individuals would execute and enforce the directives. ${ }^{425}$ In contrast, he perceived that subordinate civilian officials often interpreted his directives as merely "an invitation to begin debate," and he could not always assume ultimate compliance. Moreover, he noted that the vast majority of senior civilian appointees have little understanding of the organizational military and the encompassing leadership responsibilities formerly held

\footnotetext{
${ }^{424}$ Personal interview with a former Air Force four-star general, 4 January 2013, Pentagon City, Virginia.

${ }^{425}$ Personal interview with former Air Force two-star and current SES member, 1 November 2012, Washington D.C.
} 
by RSOs. This factor often frustrated RSOs that entered the SES, but although he admitted that "pride" accounted for some discontent, the larger frustrations stemmed from what RSO's perceived as affronts to their decision-making autonomy.

What one RSO labeled "hidden power" within civilian executive organizations also proved vexing for RSOs. The military structure establishes clear lines of supervision and accountability, and even the lowliest foot soldier knows not only his immediate supervisor, but successive levels as well. Civilian bureaucratic authority by contrast reflects one's level of organizational influence, not necessarily one's relative position on a formal hierarchy chart. Reflecting on his experience working with civilian leaders, an Army four-star RSO recalled, "[e]ven as a four-star general responsible for an entire geographic area, in my dealings with the civilian executive branch I seldom knew who the visible actors were. Members of Congress and executive officials routinely used 'proxies' to either get information or float alternative ideas to gauge likely reactions." While disorienting, the former four-star alternatively suggested that the less hierarchical civilian structure often worked to his advantage. For example, as a pre-GoldwaterNichols CINC, gaining access to the Secretary of Defense was a slow and cumbersome process because military norms dictated that all correspondence pass through the joint chiefs system regardless of the issue. In contrast, the RSO explained that when he encountered issues related for instance to the State Department or CIA, he simply contacted their top officials directly. This type of circumvention represented a cardinal sin within the military structure, but the deputies and the senior leaders he bypassed in 
the civilian agencies seemingly took no umbrage at such maneuvers, and more characteristically, expected it.

An Army one-star RSO, a former administrator of the Federal Highway administration, offered similar comments and acknowledged that adapting to hidden power often proved disorienting when he entered civilian government. He explained that as an active-duty officer, when he first assumed a posting he situated himself to his new responsibilities by contemplating three questions: who do I work for; what defines success and who defines it; and, who is in my corner. According to this officer, answering these questions as an executive branch official proved extremely difficult and often required great effort in "reading between the lines." He emphasized that difficulties in dealing with hidden power become even more prominent at the state and local level where highly personal politics often added to its perplexities. ${ }^{426}$

Despite the distinct organizational differences discussed above, the RSO group agreed that some military careers better prepare officers to overcome the cultural divide than others. A former two-star and SES member noted that officers whose active-duty experiences included working closely with civilian workers understandably made the transition to the executive branch much easier. ${ }^{427}$ This particular RSO's military background included significant leadership positions in organizations focused on research and development, engineering, and acquisition which are typically populated heavily with civilian officials. These experiences gave him an early appreciation of the

\footnotetext{
${ }^{426}$ Personal interview with former Army one-star RSO, 26 February 2013, Washington D.C.

${ }^{427}$ Personal interview with former Air Force two-star and current SES member, 1 November 2012, Washington D.C.
} 
organizational culture differences, and a better understanding of the civilian career incentives that often perplexed other RSOs.

A former Army one-star similarly cited his experience in the Army Corps of Engineers as easing his transition to the civilian executive branch. The Army Corps of Engineers contains an important organizational division between sub-organizations that actively participate in combat operations and those that focus on domestic projects like waterway developments. Active military members obviously populate the combat units, however, approximately 150 active senior military officers supervise upwards of 40,000 civilian engineers and support personnel in the non-combat arm of the engineering corps. Throughout their careers, the military officers within the corps bounce between these two organizational units and putatively develop better interagency skills as compared to officers who remain solely within combat branches. This structure allows officers to develop combat engineering expertise, but also the management skills necessary to oversee larger civilian projects. The RSO reflected that the exposure to both sides of transportation engineering makes these engineering corps officers uniquely valuable to executive administrations. To illustrate, he noted that he was the first department official to deploy in support of the Iraqi provisional government following the war because his RSO status provided him the credibility to integrate U.S. military and civilian organizations and objectives.

Cultural differences perhaps dissuade RSOs from considering some executive branch positions, but one interviewed officer emphasized that other federal agencies 
closely resemble military organizations and culture which make them attractive to some former officers. For example, the two-star SES officer at the Customs and Border Protection agency oversees the world's largest aviation and maritime law enforcement agency. ${ }^{428}$ The organization encompasses over 1,200 law enforcement officers, 250 plus aircraft and 297 marine vessels, a force more capable than some first world militaries. According to the agency's website, the organization is also "the most experienced operator of Unmanned Aircraft Systems in the Homeland Security missions on the world stage." ${ }^{429}$ The Customs and Border Protection's office in Washington's Reagan Building embodies the atmosphere of an operational military unit and appears a stark contrast to the other bureaucratic agencies in the building. The senior office personnel, including the interviewee, wear military style flight suits, rank emblems that mirror the active military, and each official carries an unconcealed weapon in the same type of shoulder holsters donned by military aircrew. The RSO explained that the organizational structure and mission focus of the agency matched military units, a factor which admitted influenced his decision to accept the position and forego job opportunities that he estimated paid 5-6 times his SES salary. Citing the federal government's expanded security focus, this official envisaged that an increasing number of RSOs would favorably consider this type of executive branch service specifically because of their hybrid culture.

\footnotetext{
428 "Office of Air and Marine - CBP.gov," accessed December 4, 2012, http://www.cbp.gov/xp/cgov/about/organization/assist_comm_off/amo_assistant_commissioner.xml. ${ }^{429}$ Ibid.
} 
Cultural differences obviously do not only impact RSOs, but bureaucrats often face equally important misperceptions of former military officers related to their political loyalties and their ability to adapt to leadership styles more characteristic of civilian organizations. A RSO's image of transcendent politics may actually provoke distrust in fellow political appointees who perceive that their own future opportunities and professional goals are directly tied to partisan fealty. A RSOs apolitical orientation may therefore be viewed by fellow appointees as a tepid commitment to the current administration.

Related to leadership styles, the former Army Corps of Engineer one-star recalled that upon his arrival at the Federal Highway Administration his former status as a G/FO created an air of suspicion among civilian workers. He noted: "I could tell they were watching intently to see if I was going to be a 'Patton' in my leadership style." Ray Navas, a retired Army Reserve Major General and former assistant Secretary of the Navy, offered a related anecdote which arguably highlights the trepidation that often surrounds the arrival of an RSO to a civilian agency. Following the announcement that General Petraeus as CIA chief, a former civilian coworker that now worked at the $\mathrm{CIA}$ contacted Navas and asked him to meet with a small group of the agency's relatively senior officials. Although Navas advised that he did not know Petraeus personally, the coworker wanted the former general to explain how they should adapt to an RSO boss. Navas said he was surprised by the group's apprehension and expectation that an RSO would impose a dramatically foreign type of organizational leadership on the spy agency. To allay their fears and to emphasize that RSOs, like senior leaders across 
government and the private sector, each possess their own distinct leadership styles, Navas recalls jokingly chastising the officials; he remarked that the country was in grave danger if its premier intelligence agency had to ask him for insight on a senior government leader!

Stereotypes about RSO leadership styles also pervade private sector organizations. As an illustration, a Navy Reserve two-star RSO described an event where the CEO of defense contractor General Dynamics addressed a group of RSOs gathered at a social and networking event sponsored by the Flag and General Officers Network. ${ }^{430}$ The CEO announced that in preparation for his presentation, he conducted an informal survey of company personnel that asked for their perceptions on executive leadership styles. The survey aimed to compare attitudes within the company regarding the relative favorability of RSO executives and those executives from predominantly civilian backgrounds. The CEO reported to the gathered RSOs that the survey results painted a disappointing portrait of them. He described a common perception held by employees that RSOs conveyed an aura of entitlement and demanded perks and staff support that other civilian executives simply did not. The surveyed personnel noted that this perceived behavior created resentment among the employees toward the former senior officers. Additionally, the employees also resented the perceived hierarchical decisionmaking structure instituted by some RSOs, and preferred the flatter organizational

\footnotetext{
${ }^{430}$ The Flag and General Officer Network is an organization that facilitates active interaction and networking among retired senior officers. See http://flagandgeneralofficersnetwork.org/ppsa.html
} 
structure that they associated with career civilian executives. ${ }^{431}$ The former Navy officer recalled that the CEO comments surprised many of the attending RSOs. He did note, however, that the CEO later relinquished his position to an RSO, and he contemplated what results an updated survey would produce when an RSO actually sat at the helm.

Recent media attention on the surprising perks enjoyed by senior military officers perhaps makes the purported survey findings referenced in the last paragraph more credible. A front page article in the 18 November 2012 Washington Post painted the G/FO world as one of 28-car motorcades, aircraft on demand, personal chefs, and aides to mow lawns and take care of dry-cleaning. ${ }^{432}$ Even former Secretary of Defense Robert Gates expressed some dismay over the perks, explaining that as the Pentagon's senior leader his perquisites nowhere near matched those of his statutory subordinates. Gates, half-jokingly, compared the treatment of his neighbor, Chairman of the Joint Chiefs, Admiral Mike Mullins, with his own: "I was often jealous because he [Mullins] had four enlisted people helping him all the time." Gates said that he often complained to his wife, "Mullen's got guys over there who are fixing meals for him, and I'm shoving something into the microwave. And I'm his boss!"433 Two reserve RSOs, both who formerly held positions in the executive branch and the private sector, suggested that

\footnotetext{
${ }^{431}$ In addition to the negative publicity surrounding the "perks" of general officers and the large paychecks many receive from contractors when they retire, recent journalistic accounts also have focused on anecdotes of "tyrannical" leadership styles of some G/FOs; the insinuation is that the military's rigid hierarchical structure breeds and promotes such leadership characteristics and thus makes RSOs even less attractive to personnel in civilian organizations. While such insinuations are interesting and obviously relevant to our understanding of RSOs, I'll leave further research on this topic to other social science disciplines. In any case, for an example of journalistic accounts see Washington Post article, Londono, "Accusations Against Generals Cast a Long Shadow over Army." 28 October 2012

${ }^{432}$ Rajiv Chandrasekaran and Greg Jaffe, "The Four-star Lifestyle: Petraeus Scandal Prompts Critique of Generals' Perks.," The Washington Post, November 18, 2012.

${ }^{433}$ Ibid.
} 
many RSOs without private sector experience do not realize that these luxuries aren't prevalent in the corporate world. One of the reserve officers, and formerly a civilian attorney in the Department of the Navy, recalled the surprise of the Secretary of the Navy, former Lockheed CEO Gordon England, when he discovered the extra benefits enjoyed by G/FOs. According to the RSOs account, England lamented, "My secretary and I essentially were Lockheed-Martins' operations division and we didn't have any of these nice perks!" ${ }^{434}$

Potential factors in the RSO-executive branch relationship discussed to this point-location, financial, and professional culture-encompass significant terrain, but leave other factors, for instance, individual prestige, political power, patriotic duty, professional interests, etc. neglected. Of these factors, conceptions of patriotic duty are perhaps the easiest to address first. If asked to serve in an ES position by the President, not surprisingly, nearly all the RSOs said that their conceptions of patriotic duty would make it extremely difficult to rebuff a commander in chief. The one exception, the victim of the "bell" discussed earlier, professed more confidence that he could say no to the President. He deemed his 40 years in the military as fulfillment of his public service obligations and he did not aspire to a 'lifetime' dedicated solely to it. Adding credibility to his assertion, the former four-star explained that he refused a nomination by his West Point classmates for a prestigious Lifetime of Service award given annually at the military institution. The general explained, "I served nearly 40 years in the military and

\footnotetext{
${ }^{434}$ Personal interview with former Air Force Reserve two-star general, 1 November 2012, Alexandria, Virginia. The RSO that relayed this anecdote paraphrased England's quote, but was confident his recollection captured the tone.
} 
my only goal was to be a colonel in the infantry. However, I still don't consider that a 'lifetime' of service and told them I would not accept any such award." ${ }^{435}$

The former ES appointees interviewed acknowledged that a sense of duty greatly influenced their decision to accept their PAS nominations. Admittedly, professions of a dedication to civic duty, however, are not unique to RSOs. Few political appointees, civilian or military, neglect to exclaim their selfless motivations and humble reluctance in answering the nation's call. Considering the high levels of public trust in the institutional military, RSO duty-bound claims perhaps invite less skepticism than, for instance, appointees from corporate America. As an explanatory factor in understanding the number of RSOs in executive administrations, however, the sincerity of duty-bound claims by civilian or military appointees belies reliable measurement.

The prestige associated with executive branch appointments also presumably motivates potential nominees, civilian and military alike. In the case of the most senior RSOs, however, recent history suggests that politics more likely risks diminishing their individual prestige rather than advancing it. Most well-known RSOs that held executive positions in the post-Cold War period arguably witnessed a decrease in public prestige following their executive service. For example, Alexander Haig, Colin Powell, David Petraeus, and James Jones all arguably left executive service with degraded public reputations. Even General George Marshall, who attained the highest levels of American public esteem, departed executive service with the ridiculous yet powerful

${ }^{435}$ Personal interview with former Army four-star, 16 January 2013, Crozet Virginia 
drums of McCarthyism nagging at his near pristine image. ${ }^{436}$ Eisenhower left office with unprecedented popularity ratings near the 70th percentile, but it is perhaps difficult to imagine that even the remaining 30 percent of America did not earlier approve of Ike following World War II. ${ }^{437}$ Although Petraeus personally submarined his own reputation, his position as the Director of the $\mathrm{CIA}$, and the associated low public profile required of its incumbents, did not necessarily represent a step up on the prestige ladder from his image as a warrior general and savior of the Iraq War. Brent Scowcroft perhaps represents an exception, but his public reputation as a military officer in no way rivaled the others mentioned. Other potential exceptions may include Lieutenant General Barry McCaffrey and General Eric Shinseki. McCaffrey, increased his public image as Clinton's Drug Czar, and Shinseki, Obama's choice to lead the VA, became a well-known symbol of the principled and practical reasoning ostensibly ignored by the Bush Administration prior to the Iraq invasion. Although both McCaffrey and Shinseki became more publically recognizable figures, neither has demonstrated any inclination to capitalize on their public prestige as a springboard for higher office.

The examples from the last paragraph suggest that executive branch service does not offer RSOs the most fruitful route to build or maintain public prestige. When asked to relate their former status to an equivalent civilian position, the four-star RSOs interviewed considered positions below ES-level two as lateral moves at best, which

\footnotetext{
${ }^{436}$ Ed Cray, General of the Army: George C. Marshall, Solider and Statesman (New York: W. W. Norton \& Company, 1990), 686.

${ }^{437}$ See Gallup, "Presidential Approval Ratings-Gallup Historical Statistics and Trends,"www.gallup.com/poll/116677/presidential-approval-ratings-gallup-historical-statisticstrends.aspx. Accessed 21 March 2013.
} 
leaves only a tiny pool of positions they see as comparatively prestigious. This RSO perspective invites one to imagine whether a figure like Petraeus, upon his first arrival at CIA headquarters, felt like a former rock-star whose motorcades and long tail of "groupies" are a distant memory, or, in Petraeus's case, at least most of the groupies.

The traits ascribed to RSOs in Chapter 2 suggested that G/FO prestige rested in large part on their political transcendent image. The RSO group consistently noted that they valued this image and resented that their acceptance of an executive branch appointment may be interpreted as a revelation of their partisan colors. The former two-star and DNI appointee claimed that his reluctance to have a partisan affiliation attached to him weighed heavily on his decision to accept his nomination. The officer professed that he did not maintain a partisan affiliation, but he understood that accepting an appointment in a Republican administration likely destroyed the possibility of later consideration by Democratic administrations. As a military officer, he said he had placed great importance on maintaining a non-partisan image, and felt that it remained important for him as an RSO. Citing his commitment to a non-partisan image, the RSO claimed that he even refused to make a small financial contribution to the congressional campaign of his former Air Force Academy roommate despite their close friendship.

The preceding discussion has arguably portrayed executive branch positions as readily available options for former senior officers if they only offered their services. The RSOs most familiar with the appointment and SES hiring process emphasized that 
nothing could be further from the truth. The five former executive branch officials in the interview pool made it clear that earning a SES or ES level position requires passage through an extremely competitive process and administration officials charged with filling these posts do not routinely solicit or embark on exhaustive talent searches for interested RSOs. As a retired Navy Reserve rear admiral, former PAS appointee to the Federal Maritime Commission, and a founder of the Flag and General Officer Network, one particular officer I interviewed held a unique vantage point on executive branch employment options for RSOs, and he provided valuable insight on the disadvantages RSOs have in gaining a post in an administration. ${ }^{438}$ Moreover, during his tenure on the Federal Maritime Commission, Reagan administration officials tasked this officer with organizing social forums designed to build professional networks and facilitate better interagency relations among political appointees. Based on these experiences, he explained that when many G/FOs retire they have woefully inaccurate perceptions of the civilian employment environment. According to Navy RSO, their misunderstandings reflected the little time G/FOs spend developing post-retirement employment plans and also their pervasive assumption that private and government interests would actively pursue them. He described that G/FOs, and especially regular officers, become so absorbed in their current military responsibilities that they devote amazingly little time to preparing and solidifying contacts necessary for enhancing future employment opportunities. The former admiral reflected that features embedded in the military career structure directly contributed to this lack of foresight. As discussed earlier, the

\footnotetext{
${ }^{438}$ See "The Flag and General Officers' Network" website at http://flagandgeneralofficersnetwork.org/whoAreWe.html
} 
military career structure outlines a rather clearly defined path for advancement, but other than achieving success in their current position, senior officers otherwise have relatively little control in the direction of their careers. After a 30 plus year career, one with many important career decisions made for them, RSOs often struggled to transition to an environment where the next career step isn't so well-defined or obligatory.

Reflecting on his experience with the Flag and General Officer Network that he founded, the former Navy two-star said many serving officers, in particular regular officers, often adhered to an overly rigid philosophy regarding the probity of contact with civilian and commercial enterprises. Although their commitment to avoid conflicts of interest was itself a desirable characteristic, he suggested many officers took this attitude to unnecessary extremes. As a result, they neglected opportunities to make and foster important political and social connections vital to securing post-retirement employment, including executive branch positions.

The retired rear-admiral further explained that many RSOs receive a discomforting surprise when their expected recruitment doesn't materialize. Based on his experience as part of the Reagan administration's nomination team, he described the appointment process as push rather than pull oriented. Those responsible for filling the huge number of ES appointments rarely see any shortage of qualified applicants, and unless an individual forcefully advocates on their own behalf, or has political connections to advocate for them, the chances of an executive level appointment are 
virtually nil. From his perspective, RSOs rate very poor at the push part because it isn't something their previous careers prepared them to do.

The same former rear-admiral also emphasized that regular officers lack a longterm presence in any one location, a career feature which significantly impedes later opportunities for political appointments. He considered reserve or National Guard RSOs much better positioned for political opportunities than regular officers in large part because of their geographic stability. Their relative permanency of residence helps them cultivate and sustain networks of business contacts and political operatives at the local and state level. As a consequence, the former G/FO observed that reserve and National Guard officers had less social inhibitions to actively engaging in politics and building the political contacts that underpin much of the appointment process. Moreover, regular officers typically don't have official residence status in their assigned locations, which often impedes even basic political participation like voting in local elections. An Air Force four-star RSO added to this assessment, claiming that RSOs were comparatively ignorant on basic understandings of how local and state governments function. ${ }^{439}$ After 35 plus years of military service, the Air Force RSO described his lack of knowledge in these areas as a huge personal and professional "blind spot." ${ }^{440}$

Using the empirical data in Chapter 3, I examined the supposition that reserve officer may hold an advantage over regular officer in securing appointments because of their relative geographic stability. The findings from this cursory study show only a

\footnotetext{
${ }^{439}$ Telephone interview with former Air Force four-star, 8 February 2013.
} 
weak correlation with this supposition, at least at the ES levels. Of the 82 executive branch RSO appointments (Coast Guard excluded), only eleven individuals were reserve or Guard officers. Reserve officers do not retire at the four-star rank and only a handful retire at the three-star rank, but former one and two star reserve officers comprise approximately $33 \%$ of the total RSO population. Based on these figures, RSOs are actually underrepresented compared with former regular RSOs. Unlike regular officers, Reserve and National Guard RSOs have varied civilian careers where they develop expertise in civilian endeavors as well, so it is possible that the rear-admiral's supposition discussed earlier may manifest itself in an expanded dataset. For example, reserve and Guard RSOs may have skill sets from their civilian professions that better coincide with ES or SES billets in the more civilianized HEW, Treasury, Commerce, and Justice departments.

A retired Air Force two-star reserve officer and attorney, elaborated on some additional considerations related to differences between reserve and regular officers with respect to gaining an SES position. ${ }^{441}$ As a civilian, this officer served in the career SES as the Assistant General Counsel for the Department of the Navy, and as a reserve G/FO, he was an assistant to the Air Force's Judge Advocate General. The former G/FO explained SES appointments were rarely granted to individuals from outside a department, but instead positions typically went to officials already serving in a particular organization. In his experience, this characteristic of the hiring process made it a much more difficult task for those on active-duty. Whereas reserve officers could

${ }^{441}$ Personal interview with Air Force Reserve 2-star, 1 November 2012, Alexandria, Virginia. 
hold lesser civilian positions in an agency and wait for an SES position to open, regular officers only remained inside agencies for relatively short periods before departing for other assignments.

The RSOs that provided the interview responses admittedly represent only a small sample of retired military officers, and their respective relationships to the executive branch cannot compare to the likes of a Colin Powell, James Jones, or David Petraeus. However, the interview responses in this study suggest some general conclusions can be made that overwhelmingly reinforce the soldier-statesman interpretation of RSO behavior and not the institutional antagonist outlook that could potentially produce a harmful version of military colonization. First, RSOs do not hold homogeneous perspectives on the probity of former senior officers serving in the executive branch let alone consensus on more traditional forms of political participation. Their perspectives ranged from beliefs that former military G/FOs should completely abstain from executive branch service while at least one saw such service as a highly positive aspect of American democracy because it showed a reintegration of senior military officers into civil politics. Most, however, held a middling view that distinguished the highest profile political positions from those positions that capitalized on unique and narrow forms of technical expertise possessed by some RSOs.

Second, while some comments reflected distaste for civilian bureaucratic culture, the RSO responses revealed no evidence of a widely shared disdain for civilian executive branch officials. Unsurprisingly, the RSOs expressed pride in the values and 
work ethic they perceived within the military's culture, but they also universally showed a reflective understanding and acceptance of the innate messiness of the bureaucracy in a democratic system.

Third, the RSOs in the group strongly rebuked the notion that a deleterious military colonization process was taking place within the executive branch. Moreover, they rejected any assertion that those RSOs who did serve, did so as part of a concerted effort to bolster military influence by installing burrowed advocates in the executive branch. The notion of military colonization itself struck them as a complete misrepresentation of RSO-Executive Branch service.

Fourth, and perhaps most telling, the RSOs that had held executive branch positions viewed their experiences as a continuation of their commitment to national service and asserted that all other incentives paled in comparison. Even those RSOs who believed former senior military officers should refrain from executive branch service, still acknowledged that the vast majority of those RSOs who served in such positions, did so primarily because of their devotion to serving the nation and civicrepublican virtue. 


\section{Chapter 6 Conclusion}

If a military officer feels no interest in the important political struggles of the day, he cannot of course care for the results which they produce; he acknowledges himself at once to be a mere machine, and automaton, a Swiss, a hireling, a "servant in livery," a man who is up for the highest bidder, who would serve the Russian Autocrat, the British King, or even Louis Phillipe, provided the pay and the rank were sufficient temptations.

Letter to the Editor, Army and Navy Chronicle, 13 January 1836

The potential consequences presaged by military colonization demand that democratic citizens continuously maintain close scrutiny on the relationship between RSOs and executive branch politics. Executive branch RSOs that are contemptuous of democratic politics, prioritize an institutional loyalty to the military over national interests, or lose sight of their subordinate position to civilian officials, do indeed represent a risk to American politics, in particular to true civilian control of the military. Whereas the "Man on Horseback" remains only a remote possibility, the threat of military colonization is substantial.

While recognizing the possibility of this threat, this study uncovered little evidence that such a danger has become realized in the post-Cold War period. In key national security policy-making positions, RSO participation levels do not differ markedly from the earlier patterns of post-World War II executive administrations. The evident 
increases beneath the key positions reside in agencies and departments that RSOs have traditionally maintained a strong presence throughout the post-World War II period. Furthermore, the empirical evidence does not signify that RSOs as a group possess homogenous ideological orientations that fall outside the political mainstream. The ideological orientations of senior military officers instead reveal that they are often more protective of some central liberal values.

RSOs do demonstrate conservative dispositions that perhaps set them apart from much of American society; however, their conservatism is steeped in traditional martial values like loyalty, service, and duty that cannot be mapped onto contemporary left-right ideological labels. Their orientation can best be understood as small ' $c$ ' conservatism, a form distinctly different than a conservatism characterized by ideological rigidity or disdain for liberal democratic culture. The most prominent executive branch RSOs studied during the period better resemble the credible countervailing officials, trusted agents or independent experts contained in the RSOexecutive branch relationship categories. They have served as checks against undue military influence rather than burrowed advocates for active-duty leaders and narrow military interests.

Nothing uncovered during the research suggests that active and retired military leaders collude to populate the executive branch with loyal RSOs to do their bidding, an insinuation emphatically rejected by the RSOs interviewed for this project and deemed insulting to the personal and professional honor. Those RSOs who had served in the 
executive branch instead recognized a distinct dividing line between their responsibilities as a civilian official and their loyalty to the institutional military. In oral history comments related to Colin Powell, former Secretary of State George Schultz reinforced this perspective: “...in the services I think people get trained about roles. They understand when you're a General in charge and when you're advising and so on. It's part of their training to see if you're in this role, you do this, if you're in that role, you do that. So it came much easier to him." ${ }^{442}$ While Schultz's assessment related specifically to Powell as an active-duty officer, nothing uncovered in this research suggests that his comments are not equally applicable to the RSOs discussed in this work. Rather than expanding military influence, the RSO interviewees who had served in senior executive branch positions professed two basic reasons for entering executive service: 1) they were asked by administration officials, and 2) they held a strong ethic of public service to the nation. All other motivations paled in comparison.

The foundational scholars of civil-military relations, Huntington and Janowitz, did not make the RSO-executive branch relationship a central piece of their studies. Nonetheless, they acknowledged the military colonization claims that swirled after World War II, concerns that bear a remarkable resemblance to the ones of contemporary purveyors. ${ }^{443}$ However, even Huntington, who prescribed the strict dichotomy between civil and military spheres, did not seem overly concerned with the large number of RSOs that entered executive service immediately after the War. He

\footnotetext{
${ }^{442}$ Miller Center. (2005). Interview with George P. Shultz. Charlottesville, VA: University of Virginia. Retrieved from http://millercenter.org/president/reagan/oralhistory/george-shultz

${ }^{443}$ Huntington, The Soldier and the State, 355-361; Janowitz, The Professional Soldier, a Social and Political Portrait., 377-378.
} 
noted that an estimated 150 military men held important policy-making positions in the federal government in $1948 .{ }^{444}$ Changes in the security environment and the American executive branch government may have altered the dynamics of the RSO-executive branch relationship since then, but Huntington's tepid concern remains appropriate for the current environment:

Virtually all the criticism of the military influx was couched in terms of abstract constitutional and political principles and generalized dangers to civil government. With a few exceptions, it was impossible to demonstrate that the actions of any particular military officer reflected the inherently dangerous qualities of the military mind. It was all very well to cite the general influx of military men as evidence of a trend toward the garrison state. But, when one got down to the specifics of Bradley as Veterans Administrator or Marshall as Secretary of State, the threat of militarization rapidly evaporated. The professional officers blended into their new civilian milieu, serving nonmilitary ends, motivated by nonmilitary considerations, and performing their jobs little differently from their civilian predecessors and successors. ${ }^{445}$

The post-Cold War RSOs discussed in this work arguably do not possess the lionized reputations of Marshall and Bradley, but figures such as Brent Skowcroft, Colin Powell, James Jones, and James Watkins could equally fit Huntington's depiction.

In sum, the empirical data strongly challenges the notion that an insidious process of military colonization characterizes the post-Cold War period. Nevertheless, more research is needed to provide a full account of the relationship between RSOs and the federal executive branch. First, a deeper examination into RSO appointments to PAS positions prior to the Bush 41 administration would prove valuable. The relative

\footnotetext{
${ }^{444}$ Huntington, The Soldier and the State, 357.

${ }^{445}$ Huntington, The Soldier and the State, 361.
} 
stability in the key positions over the post-World War II period shown in this study may mask potential trends in lower-level PAS appointments of earlier administrations.

Future studies also need to reach further into the SES and uncover broader trends in RSO participation and its relative influence, especially in those agencies related to the growing Homeland Security measures. A closer examination of the SES positions is of particular importance because these officials represent a more permanent yet less visible influence on the executive branch. Moreover, a future investigation should shift its focus from G/FOs and examine the significantly larger group of former military officers that retire at lesser ranks. As discussed in Chapter 2, most officers retire after a comparatively brief $20-25$ career which leaves them with the time, experience, and unique skills to embark on another complete career in executive branch government. The larger population of senior non-commissioned officers also shares many of these same characteristics, and in many respects it is this group of military members that possess the greatest technical expertise. Interestingly, while G/FOs are the predominant focus in civil-military relations, in Democracy in America Alex de Tocqueville saw the non-commissioned officer ranks as the major concern regarding militarization. Tocqueville writes:

Like the officer, the noncommissioned officer has in his thinking broken all the bonds that attached him to civil society; like him, he has made the military his career, and perhaps more than he, he has directed all his desires in this direction alone; but he has not yet attained, as has the officer, an elevated and solid position where it is permissible for him to stop and breathe at ease while waiting to be able to climb higher. ${ }^{446}$

\footnotetext{
${ }^{446}$ Tocqueville, Democracy in America, 625.
} 
Tocqueville could not have envisioned the degree of professionalism, competency, and education of today's U.S. military non-commissioned officers and using his comments here unfairly characterizes these vital military personnel. However, his comment does stand as a reminder that civil-military relations research cannot stay solely focus on characteristics of the elite ranks alone.

Temporary or informal participation of RSOs in the executive branch also deserves more scholarly attention. RSOs routinely serve on special commissions, as special envoys, or in advisory positions that do not fit within the PAS, PA, or SES system but still deserve consideration in civil-military studies. Some notable RSO examples include Admiral Jonathan Howe, U.N. Special Ambassador to Somalia during the Clinton administration, General Anthony Zinni, Bush 43's special envoy to the Middle East, and Lieutenant General Jay Garner who served as the Director of the Office for Reconstruction and Humanitarian Assistance (ORHA) prior to the 2003 Iraq invasion. Even more significant may be those RSOs who unofficially serve as advisors to executive officials or as private conduits between the Pentagon and civilian leaders. In his account of Bush 43's surge decision in 2006, journalist Bob Woodward portrays retired Army general Jack Keane as a central actor in developing the plan, persuading key officials of its necessity, and even influencing decisions on which general officers were removed or chosen to execute the new strategy. ${ }^{447}$ At the time, Keane served as a member of the Defense Policy Board, but his informal actions went far beyond a simple advisory role and complicated lines of accountability for civilian and military leaders alike. In one

\footnotetext{
${ }^{447}$ Woodward, The War Within.
} 
instance, the Army Chief of Staff personally admonished Keane: "It's not appropriate for a retired general to be so far forward advocating a policy that he is not responsible or accountable for." ${ }^{448}$ Efforts like Keane's elude formal congressional or media oversight despite their key roles in developing and implementing U.S. policy. This type of RSO activity directly influences the contours of the civil-military relations nexus and current research in the sub-field neglects to give it full treatment.

An analysis on the ultimate policy impact that RSOs have is also sorely needed. While this study contends that RSOs have often served as checks against undue military influence on larger, more publicized national security issues, a closer look at more mundane administrative policy and budgetary areas will help to establish just how independent RSOs really are from their Pentagon ties. For instance, their participation as witnesses in congressional budgetary hearings on issues such as military pay, base closures, and health benefits, etc., may demonstrate systematic collusion between private citizen RSOs and military leaders.

Finally, this study has focused predominantly on internal factors related to civilian control of the military and only tangentially discussed external variables. Future studies also need to consider the effect of the external threat environment and its influence on what roles RSOs play in the executive branch. The empirical data from Chapter 3 shows an increase after 9-11 but similar increases are not as apparent during other changes in the threat environment like Vietnam or the first Gulf War. Some scholars have suggested that external threats are the primary independent variable in

\footnotetext{
${ }^{448}$ Ibid., 371.
} 
understanding the degree of civilian control over the military and their models may prove valuable when overlaid on the RSO-executive branch relationship. ${ }^{449}$ While this project has focused solely on the American case, International Relations and Comparative Politics scholars may find it fruitful to investigate the role of RSOs in countries with different institutional arrangements, political cultures, and degrees of military professionalism.

Although this study concludes that post-Cold War administrations have avoided the specter of military colonization, past success provide no guarantee for the future. With respect to the RSO-executive branch relationship categories, the preceding research makes the case that RSOs have not manifested the dangerous Institutional Antagonist aspects of their unique traits. However, similar to the general categories, the behavioral sub-categories cannot be assumed static. The question must therefore be asked, what forces could potentially cause such a shift to the alternative behaviors? Three current trends heighten the risk for upcoming administrations, and these trends should motivate civilian and military leaders to remain open to additional auxiliary precautions, both institutional and cultural.

First, the depth of public distrust in the federal government appears to be accelerating. This trend largely stems from the public's perception that political leaders are incapable of addressing the fundamental moral, economic, and social issues facing

\footnotetext{
${ }^{449}$ In particular, Desch argues that variables such as individual leaders, military organizations, state structures, and societies are only intervening variables in understanding civilian control of the military and external and internal threats are the true independent variables. Desch doesn't discuss RSOs in any manner but his theory does suggest a potential relationship. See Desch, Civilian Control of the Military: The Changing Security Environment.
} 
the country. This type of civic environment may tempt the American public to look increasingly to popular military leaders for organizational and moral leadership. RSOs have not proven immune to moral or professional transgressions, (e.g., Petraeus and McChrystal), but these lapses incur highly visible and definitive consequences when compared with other public officials. This perceived accountability then produces even more trust in the integrity of the institutional military, its active leaders, and RSOs, and subsequently heightens the attractiveness of these figures as political actors. As Holsti simply notes: "[T]he disposition of the military to intervene can be reduced...by strengthening the legitimacy of civilian government." ${ }^{450}$

The second trend relates to the nature of the national security threat facing the United States and the methods used to counter those threats. The organizational changes and assignment of security responsibilities have blurred distinctions between military functions, intelligence roles, and civil law enforcement functions as well as transportation and energy responsibilities. The clean division between civilian and military spheres prescribed by Huntington no longer seems remotely plausible, or even desirable. As basic responsibilities become blurred, then so do distinctions regarding who should lead the organizations responsible for these functions. The military leader becomes a viable option for roles previously reserved solely for civilian officials. Civilian and military officials must take care to not conflate the desire for an overlap of functions

\footnotetext{
${ }^{450}$ As quoted in Feaver, “Civil-Military Relations," 229.
} 
with a merging of functions. ${ }^{451}$ If RSOs are to serve as civilian officials, their executive branch responsibilities must reflect an overlap and not a merging.

Finally, senior political leaders recognize the political value of RSO endorsements as a means to demonstrate a close affiliation with the institutional military. Unfortunately, RSOs have demonstrated an increasing willingness to oblige them and to serve as the prestigious proxies alluded to in this study. ${ }^{452}$ This trend fuels added distrust among civilian and military officials, corrodes the military's desired image as a non-partisan servant of the state, and alters public perceptions toward RSOs who do serve in the executive branch. The confluence of these trends, distrust in government officials, the blurring of civil-military functions, and the willingness of RSOs to overtly participate in the endorsement game, portend a scenario where an unreflective public perhaps too energetically embraces RSOs as political actors.

While RSOs in the executive branch have characteristically proven safe for democratic government in the United States, auxiliary precautions that address the confluence of these three trends must remain a constant focus for civil and military leaders. Executive officials and legislative leaders must consistently assess the need for institutional mechanisms to reduce colonization risks, inculcate professional norms and expectations for the RSO-executive branch relationship, and ensure the positive dimensions of RSO traits remain predominant. In closing, it is worthwhile to consider some possibilities.

\footnotetext{
451 Ibid., 220.

${ }^{452}$ Golby, Dropp, and Feaver, Military Campaigns: Veterans' Endorsements and Presidential Elections.
} 
Institutional devices such as statutes that impose a cooling-off period between military service and executive branch service should be regularly revisited. Mandated pauses between military and executive branch service may help to reduce suspicions and distrust among civilian leaders concerned about political rivals in the Pentagon as well as loosen the direct connections between retired RSOs and active military leaders. The recesses could also mitigate the perception, or reality, of quid pro quo appointments. Delays may assuage suspicions among junior military members that their senior leaders are motivated by future political career incentives. Finally, such delays provide an opportunity for RSOs to gain experiences in corporate and/or state and local government, areas they acknowledge that they have little familiarity.

As noted in Chapter 3, the top civilian positions in the Department of Defense all require significant pauses between military officer retirement and PAS appointment, but few other departments or agencies impose such restrictions. ${ }^{453}$ Broader restrictions, however, must take care to consider the important distinctions between one and twostar RSOs and the elite three and four-star officers. The empirical data from this study shows that three and four-star officers represent unique political-military figures and present challenges for democratic government that lesser-known one or two-star officers do not. Lawmakers must also differentiate between which executive branch positions demand extra precautions and avoid blanket restrictions.

Civilian political leaders in Congress and the executive branch must also consider the possibility that increases in the number of RSOs in national security related positions

${ }^{453}$ See 10 U.S.C. $§ 113$. 
reflects government's failure to develop other sources of expertise. For example, President Clinton initiated a comprehensive effort to create better horizontal integration and expertise among federal civilians to enhance their national security capabilities; however, his Presidential Decision Directive 56, Managing Complex Contingencies, lacked the necessary doctrinal underpinnings and political inertia to produce any substantial changes. ${ }^{454}$ In May 2007 President Bush issued Executive Order 13434 which created the National Security Professional Development Program (NSPDP) in his attempt to address the perceived shortage. ${ }^{455}$ Stemming from the difficulties in post-conflict stability operations in Iraq and Afghanistan, the program aimed to create a civilian cadre of senior government officials that possessed broad inter-agency competencies and experiences related to national security.

In an interview for this study, former Army two-star and former director of the NSPDP Integration Office, William Navas, explained that the program continues to flounder because it receives little prioritization by top executive branch officials and many agencies resist participation. According to Navas, the absence of a shared federal definition of National Security stands as the chief obstacle in building broad executive branch support to fully implement the program. Navas explained that most agencies remained trapped in an institutional mindset that recognizes national security as solely

\footnotetext{
${ }^{454}$ John W. Yaeger and L. Erik Kjonnerod, "Educating National Security Professionals for Stabilization and Reconstruction," in Civilian Surge: Key to Complex Operations, ed. Hans Binnendijk and Patrick M. Cronin (Washington D.C.: National Defense University Press, 2009), 196-197.

455 Executive Order 13434, May 17, 2007, "National Security Professional Development," available at http://georgewbush-whitehouse.archives.gov/news/releases/2007/05/20070517-6.html; and National Strategy for the Development of Security Professionals, July 2007, available at http://www.cpms.osd.mil/ASSETS/13DCDB52B7D7453A9F78343E46F11F99/National\%20Strategy\%20for\%20Professi onal\%20Development.pdf.
} 
within the purview of the Department of Defense. This antiquated understanding discourages agencies from providing the time and resources necessary to organically produce broadly trained and competent civilian national security professionals. As a result, the Department of Defense becomes the default provider of these professionals, and, unsurprisingly, RSOs become attractive figures to fill the expertise vacuum.

Navas recommended that for those looking to minimize the threat of military colonization, the first step must include redefining national security to better reflect the current security environment. Once an agreed upon understanding is established, all departments must then be given the resources and the mandate to develop a cadre of inter-agency civilian experts that can populate and mold the national security policy process. ${ }^{456}$ Until such a cadre exists, civilian leaders responsible for the national security apparatus will instinctively look to RSOs. ${ }^{457}$

Finally, the now routine practice of RSOs using their former military ranks when publically endorsing political candidates must be reversed. Active leaders as well as RSOs must recognize that the prestige associated with their rank does not solely belong to them but embodies the reputation and honor of the entire institutional military, active and retired. Therefore, despite their civilian status, when RSOs use their military rank in support of partisan politics, they implicitly offer a reputation that is not alone

\footnotetext{
${ }^{456}$ For an historical account of efforts to develop national security professionals see: Catherine Dale, "National Security Professionals and Interagency Reforms: Proposals, Recent Experiences and Issues for Congress," Congressional Research Service Report, 26 September 2011. http://www.fas.org/sgp/crs/natsec/RL34565.pdf

${ }^{457}$ For a comprehensive analysis of the difficulties in developing civilian capacity to understand, participate and lead complex operations related to national security see Yaeger and Kjonnerod, "Educating National Security Professionals for Stabilization and Reconstruction."
} 
theirs to commit. As mentioned, this practice undermines the non-partisan image of all officers, but it also potentially injects dangerous political calculations into the G/FO promotion process. It would be naïve to think that political considerations do not already play some role in general officer advancements. Nonetheless, if expectations for future political support or promises of later quid pro quo executive branch appointments become entangled into the G/FO promotion process, the consequences for military professionalism are dire.

Returning to the epigraph that opened this study, Tocqueville reminds us of the most central protection against military usurpation: "It is not in the army that the remedy for the vices of the army can be encountered, but in the country." Despite its favorable civil-military relations past, democratic government in the United States must still remain vigilant of the "Man on Horseback" and for more insidious forms of military usurpation like those represented by military colonization. Institutional design can effectively impede some dangers, but, as Tocqueville implies, cultural norms and the force of tradition are essential. Like the early post-World War II scholars that jointly outlined the contours of civil-military relations theory, this study too finds that the cultural norms and traditions that produce military professionalism lie at the heart of the RSO-executive branch relationship. It is the soldier-statesman Marshall, and not Patton, MacArthur, or even Eisenhower, who the senior officers interviewed for this study looked to as the lodestar for civil-military relations, and the behavior of the most prominent executive branch RSOs considered in this study suggests they likely concur. 
Although the specter of military colonization presents real risks, it does not seem an apt description for the post-Cold War RSO-executive branch relationship. 


\section{Works Cited}

Ackerman, Bruce. The Decline and Fall of the American Republic. Cambridge, Mass: Belknap Press of Harvard University Press, 2010.

Apple Jr, R.W. "A Nominee's Withdrawal; Inman Withdraws as Clinton Choice for Defense Chief." The New York Times, January 19, 1994. http://www.nytimes.com/1994/01/19/us/a-nominee-s-withdrawal-inman-withdrawsas-clinton-choice-for-defense-chief.html?pagewanted=all\&src=pm.

Army Times. "Mitt Romney's 'Military Advisory Council' - Army News | News from Afghanistan \& Iraq - Army Times." Accessed November 19, 2012.

http://www.armytimes.com/news/2012/10/military-romney-endorsement-list101812w.

Bacevich, Andrew J. The New American Militarism: How Americans Are Seduced by War. New York: Oxford University Press, 2005.

Bacevich, Andrew J., and Richard H. Kohn. "Grand Army of the Republicans: Has the U.S. Military Become a Partisan Force?" The New Republic (December 8, 1997): 22-25.

Baldor, Lolita C. "Women In Combat: Leon Panetta Removes Military Ban, Opening Front-Line Positions," January 23, 2013. http://www.huffingtonpost.com/2013/01/23/women-incombat_n_2535954.html.

"Barack Obama: Press Release - Over 70 Foreign Policy Experts Announce Endorsement of Barack Obama for President," December 19, 2007. http://www.presidency.ucsb.edu/ws/index.php?pid=91967.

Barry, John, Dan Ephron, and Richard Wolffe. "The General's Marching Orders." Newsweek 152, no. 23 (December 8, 2008): 8-9.

Bernstein, Adam. "Wayne A. Downing, 67; Army General Was a Prominent Advisor on Terrorism." Los Angeles Times, July 19, 2007. http://articles.latimes.com/2007/jul/19/local/me-downing19.

Best, Richard A. The National Security Council: An Organizational Assessment. CRS Report for Congress. Congressional Research Service, December 28, 2011.

Betros, Lance. "Political Partisanship and the Military Ethic in America." Armed Forces \& Society (Summer 2001): 501-523.

Betts, Richard K. "Are Civil-Military Relations Still a Problem?" In American Civil-Military Relations: The Soldier and the State in a New Era, 11-42. edited by Suzanne C. Nielsen and Don M. Snider. Baltimore: The Johns Hopkins University Press, 2009.

Biderman, Albert D. "Sequels to a Military Career: The Retired Military Professional." In The New Military, 287-336. edited by Morris Janowitz. New York: The Russell Sage Foundation, 1964.

- - - "Where Do They Go from Here?- Retired Military in America." Annals of the American Academy of Political and Social Science 406 (March 1, 1973): 146-161.

Bland, Douglas L. "A Unified Theory of Civil-Military Relations." Armed Forces \& Society (Fall 1999): 7-12. doi:Article.

Brooks, Risa A. "Militaries and Political Activity in Democracies." In American Civil-Military Relations: The Soldier and the State in a New Era, 213-238. edited by Suzanne C. Nielsen and Don M. Snider. Baltimore: The Johns Hopkins University Press, 2009. 
Bumiller, Elizabeth. "Gates Warns of Growing Disconnect Between Country and Military NYTimes.com." The New York Times, September 29, 2010. http://www.nytimes.com/2010/09/30/us/30military.html?_r=1\&.

- - - "Powell Endorses Obama - NYTimes.com." The New York Times, February 6, 2008. http://thecaucus.blogs.nytimes.com/2008/10/19/powell-endorses-obama/.

- - . "Top Defense Officials Seek to End 'Don't Ask, Don't Tell'." The New York Times. February 2, 2010, Online edition. http:www.nytimes.com/2010/02/03/us/politics/03military.html.

Bundy, McGeorge. "Memorandum From President's Special Assistant for National Security Affairs to President Kennedy. 'The Use of the National Security Council,'." U.S. Department of State, Foreign Relations of the United States, 1961-1963, Vol. XXV, Document 4, January 24, 1961. http://history.state.gov/historicaldocuments/frus1961$63 \mathrm{v} 25 / \mathrm{d} 4$

Burk, James. "Theories of Democratic Civil-Military Relations." Armed Forces \& Society (October 2002): 7-29. doi:10.1177/0095327X0202900102.

Calabresi, Steven G., and Christopher S. Yoo. The Unitary Executive: Presidential Power from Washington to Bush. New Haven: Yale University Press, 2008.

Callander, Bruce D. "New Rules on Dual Compensation." Air Force Magazine, January 2000.

Campbell, A., Philip E. Converse, Warren E. Miller, and Donald E. Stokes. Elections and the Political Order. 99th ed. Wiley, 1966.

Ceaser, James W. Designing a Polity: America's Constitution in Theory and Practice. Plymouth, UK: Rowman \& Littlefield Publishers, 2010.

Chandrasekaran, Rajiv, and Greg Jaffe. "The Four-star Lifestyle: Petraeus Scandal Prompts Critique of Generals' Perks." The Washington Post. November 18, 2012.

Cheney, Richard B. Miller Center Presidential Oral History Project, March 16, 2000. http://millercenter.org/president/bush/oralhistory/richard-cheney.

Church, George J., Dean Brelis, and Gregory H. Wierzynski. "The 'Vicar' Takes Charge." Time (March 16, 1981): 14.

Citizens for Responsibility and Ethics in Washington (CREW). Strategic Maneuvers: The Revolving Door from the Pentagon to the Private Sector, November 2012. http://www.citizensforethics.org/page//PDFs/Reports/CREW_Strategic_Maneuvers_Pentagon_Generals_Revolving_Door_11_1 5_12.pdf?nocdn=1.

Clinton, Bill. My Life. New York: Alfred A. Knopf, 2004.

Cohen, Eliot A. Supreme Command : Soldiers, Statesmen, and Leadership in Wartime. New York: Free Press, 2002.

- - . "The Unequal Dialogue: The Theory and Reality of Civil-Military Relations and the Use of Force." In Soldiers and Civilians: The Civil-Military Gap and American National Security, 429-458. Cambridge, Mass: MIT Press, 2001.

Cohen, William. "Remarks at Yale University," October 22, 1997. http://www.defense.gov/releases/release. aspx?releaseid=1459.

Coletta, Damon. "Courage in the Service of Virtue The Case of General Shinseki's Testimony Before the Iraq War." Armed Forces \& Society 34, no. 1 (October 1, 2007): 109-121. doi:10.1177/0095327X07304191.

Converse, Phillip E. "The Nature of Belief Systems in the Mass Publics." In Ideology and Discontent,, edited by David E. Apter. London,: Free Press of Glencoe, 1964.

Crabb, Cecil Van Meter, and Kevin V. Mulcahy. American National Security: a Presidential Perspective. Pacific Grove, CA: Brooks/Cole, 1991. 
Cray, Ed. General of the Army: George C. Marshall, Solider and Statesman. New York: W. W. Norton \& Company, 1990.

Crowe, William J. The Line of Fire : from Washington to the Gulf, the Politics and Battles of the New Military. New York: Simon \& Schuster, 1993.

Crowley, Candy. "Interview with General Stanly McChrystal and General Michael Hayden." CNN Transcripts, January 27, 2013. http://transcripts.cnn.com/TRANSCRIPTS/1301/27/sotu.01.html.

Daalder, Ivo H., and I. M. Destler. In the Shadow of the Oval Office: Profiles of the National Security Advisers and the Presidents They Served--From JFK to George W. Bush. New York: Simon \& Schuster, 2009.

Daalder, Ivo H., I. M. Destler, and Karla J. Nieting. The National Security Council Project: Oral History Roundtables: The Role of the National Security Adviser. Washington, DC: The Brookings Institution, October 25, 1999. http://www.brookings.edu/ /media/Projects/nsc/19991025.PDF.

Davis, James A. "Attitudes and Opinions Among Senior Military Officers and a U.S. Cross-Section, 1998-1999." In Soldiers and Civilians: The Civil-Military Gap and American National Security, 101-128. edited by Peter D. Feaver and Richard H. Kohn. Cambridge, Mass: MIT Press, 2001. http://search.lib.virginia.edu/catalog/u4373754.

Delli Carpini, Michael X. What Americans Know About Politics and Why It Matters. New Haven Conn.: Yale University Press, 1996. http://www.washingtonpost.com/wpdyn/articles/A45657-2001May18.html.

Dempsey, Jason K. Our Army: Soldiers, Politics, and American Civil-Military Relations. Princeton, N.J.: Princeton University Press, 2009.

Department of Defense Inspector General. DoD Complied With Policies on Converting Senior Mentors to Highly Qualified Experts, but Few Senior Mentors Converted. Department of Defense, October 31, 2011.

Desch, Michael C. "Bush and the Generals." Foreign Affairs (June 2007): 97-108.

-- . Civilian Control of the Military : the Changing Security Environment. Baltimore: The Johns Hopkins University Press, 1999.

- - - "Hartz, Huntington, and the Liberal Tradition in America: The Clash with Military Realism." In American Civil-Military Relations: The Soldier and the State in a New Era, 91-112. edited by Suzanne C. Nielsen and Don M. Snider. Baltimore: The Johns Hopkins University Press, 2009.

Destler, I. M. "Donilon to the Rescue?" Foreign Affairs, October 13, 2010. http://www.foreignaffairs.com/articles/66772/i-m-destler/donilon-to-the-rescue.

Devroy, Ann. "Adm. Inman Asks Clinton To Withdraw Nomination - The Tech." The Tech. January 19, 1994, Online edition. http://tech.mit.edu/V113/N66/inman.66w.html.

Downing, Wayne A. Report to the President and Congress on the Protection of U.S. Forces Deployed Abroad. Washington DC: Downing Assessment Task Force, August 30, 1996. http://www.au.af.mil/au/awc/awcgate/khobar/downing/toc.htm.

Dunlap, Charles J. Jr. "Welcome to the Junta: The Erosion of Civilian Control of the U.S. Military." Wake Forest Law Review 29 (1994): 341.

- - . "Welcome to the Junta: The Erosion of Civilian Control of the U.S. Military." Wake Forest Law Review 29 (1994): 341.

Dunlap, Charles J. Jr. "The Origins of the American Military Coup of 2012." Parameters (Winter 1993 1992): 2-20.

Eisenhower, Dwight D. "Farewell Address." Washington D.C., January 17, 1961. http://archive.org/stream/publicpapersofth015184mbp\#page/n1/mode/2up. 
- - - The Eisenhower Diaries. Edited by Robert H. Ferrell. New York: Norton, 1981.

Ekirch Jr., Arthur. The Civilian and the Military: A History of the American Anti-Militarist Tradition. 2nd ed. Oakland, CA: Independent Institute, 2010.

Feaver, Peter D. Armed Servants: Agency, Oversight, and Civil-Military Relations. Cambridge, Mass: Harvard University Press, 2005.

- - . "Civil-Military Relations." Annual Review of Political Science 2, no. 1 (1999): 211-241.

- - . "The Civil-Military Problematique: Huntington, Janowitz, and the Question of Civilian Control." Armed Forces \& Society (Winter 1996): 149-178.

Feaver, Peter D., and Richard H. Kohn. Soldiers and Civilians: The Civil-Military Gap and American National Security. MIT Press, 2001.

Feaver, Peter D., and Erika Seeler. "Before and After Huntington: The Methodological Maturing of Civil-Military Studies." In American Civil-Military Relations: The Soldier and the State in a New Era, 72-90. edited by Suzanne C. Nielsen and Don M. Snider. Baltimore: The Johns Hopkins University Press, 2009.

Finer, S. E. The Man on Horseback; the Role of the Military in Politics. New York: Praeger, 1962.

Fishkin, James S. The Voice of the People : Public Opinion and Democracy. New Haven, Conn.: Yale University Press, 1995.

Freeman, Ben. "Testimony Before the Senate Armed Services Committee Subcommittee on Personnel on 'General and Flag Officer Requirements'." POGO: Project on Government Oversight, September 14, 2011. http://www.pogo.org/our-work/testimony/2011/nswds-20110914.html.

Gallup. "Confidence In Institutions." 24 September 2012. Gallup Polls on the Confidence in Institutions, 2012. http://www.gallup.com/poll/1597/confidence-institutions.aspx.

Garamone, Jim. “Defense.gov News Article: 'CINC' Is Sunk," October 25, 2002. http://www.defense.gov/news/newsarticle. aspx?id=42568.

Gelpi, Christopher, and Peter D. Feaver. "Speak Softly and Carry a Big Stick? Veterans in the Political Elite and the American Use of Force." American Political Science Review 96, no. 4 (December 2002): 779-793.

Gettleman, Jeffrey. "Scott Gration Resigns as U.S. Ambassador to Kenya - NYTimes.com." The New York Times, June 29, 2012. http://www.nytimes.com/2012/06/30/world/africa/scott-gration-resigns-as-usambassador-to-kenya.html?_r=0.

Gibson, Christopher P. "Enhancing National Security and Civilian Control of the Military: A Madisonian Approach." In American Civil-Military Relations: The Soldier and the State in a New Era, 239-263. edited by Suzanne C. Nielsen and Don M. Snider. Baltimore: The Johns Hopkins University Press, 2009.

Golby, James, Kyle Dropp, and Peter Feaver. Military Campaigns: Veterans' Endorsements and Presidential Elections. Center for a New American Security, October 2012. http://www.cnas.org/files/documents/publications/CNAS_MilitaryCampaigns_GolbyDro ppFeaver.pdf.

Gronke, Paul, and Peter D. Feaver. "Uncertain Confidence: Civilian and Military Attitudes About Civil-Military Relations." In Soldiers and Civilians: The Civil-Military Gap and American National Security, 129-162. edited by Peter D. Feaver and Richard H. Kohn. Cambridge, Mass: MIT Press, 2001.

Haass, Richard. War of Necessity, War of Choice : A Memoir of Two Iraq Wars. 1st Simon \& Schuster hardcover ed. New York: Simon \& Schuster, 2009.

Haig, Jr., Alexander. Caveat. New York: Macmillan Publishing Company, 1984. 
Hamilton, Alexander, John Jay, and James Madison. The Federalist. Edited by George W. Carey and James McClellan. 2nd ed. Indianapolis, IN: Liberty Fund, 2001.

Hartz, Louis. The Liberal Tradition in America; an Interpretation of American Political Thought Since the Revolution. New York: Harcourt, Brace, 1955.

Hastings, Michael. "The Runaway General | Politics News | Rolling Stone." Rolling Stone, June 22, 2010. http://www.rollingstone.com/politics/news/the-runaway-general-20100622.

Healy, Melissa. “Powell Faces Protest Over Armed Forces' Ban on Gays : Military: At Harvard Commencement, He Says That the 'President Has Given Us Clear Direction.' The General Opposes Lifting the Prohibition. - Los Angeles Times." Los Angeles Times, June 11, 1993. http://articles.latimes.com/1993-06-11/news/mn-2038_1_harvard-commencement. Heclo, Hugh. On Thinking Institutionally. New York: Oxford University Press, 2008.

Holsti, Ole R. "A Widening Gap Between the U.S. Military and Civilian Society?: Some Evidence, 1976-96." International Security 23, no. 3 (1998): 5-42.

- - . "Of Chasms and Convergences: Attitudes and Beliefs of Civilians and Military Elites at the Start of a New Millennium." In Soldiers and Civilians: The Civil-Military Gap and American National Security, 15-99. edited by Peter D. Feaver and Richard H. Kohn. Cambridge, Mass: MIT Press, 2001.

- - - Public Opinion and American Foreign Policy. Ann Arbor, MI: The University of Michigan Press, 1996.

Hooker, Richard D. Jr. "Soldiers of the State: Reconsidering American Civil-Military Relations." Parameters (Winter /2004 2003): 4-18.

Huntington, Samuel P. Political Order in Changing Societies. New Haven: Yale University Press, 1968.

- - . The Soldier and the State: The Theory and Politics of Civil-Military Relations. Cambridge, Mass: Belknap Press of Harvard University Press, 1957.

Inbody, Donald S. "Grand Army of the Republic or Grand Army of the Republicans? Political Party and Ideological Preferences of American Enlisted Personnel." Dissertation, The University of Texas, 2009.

http://inbody.net/Inbody\%20Dissertation\%20Defense\%20Draft\%205-20-2009.pdf.

Janowitz, Morris. Sociology and the Military Establishment. New York: Russell Sage Foundation, 1959.

- - . The Professional Soldier, a Social and Political Portrait. Glencoe, IL: Free Press, 1960.

Jeremiah, Admiral David. Miller Center Presidential Oral History Project, November 15, 2010. http://millercenter.org/president/bush/oralhistory/david-jeremiah.

Jervis, Robert. Perception and Misperception in International Politics. Princeton, N.J.: Princeton University Press, 1976.

Johnson, Luke. "Report: 70 Percent of Retired Generals Took Jobs With Defense Contractors or Consultants." The Huffington Post, November 19, 2012.

http://www.huffingtonpost.com/2012/11/19/defense-contractorsgenerals_n_2160771.html.

Jones, Del. "Does Age Matter When You're CEO?" USATODAY.COM, September 11, 2008. http://usatoday30.usatoday.com/money/companies/management/2008-08-12-obamamccain-age-ceos_N.htm.

Kinder, Donald R. "Pale Democracy: Opinion and Action in Postwar America." In The Evolution of Political Knowledge: Theory and Inquiry in American Politics, 104-147. edited by Edward D. Mansfield and Edward D. Mansfield Richard Sisson. Columbus OH: Ohio State University Press, 2004. 
King Jr., Neil. "The Courting of General Jones - WSJ.com." The Wall Street Journal, April 23, 2007. http://online.wsj.com/public/article/SB117729466180378622EfRd3v5nBv3QBfi5cUh2mSLhH7U_20080422.html?mod=tff_main_tff_top.

Kohn, Richard H. "Building Trust: Civil-Military Behaviors for Effective National Security." In American Civil-Military Relations: The Soldier and the State in a New Era, 264-289. edited by Suzanne C. Nielsen and Don M. Snider. Baltimore: The Johns Hopkins University Press, 2009.

- - . "Building Trust: Civil-Military Behaviors for Effective National Security." In American Civil-Military Relations: The Soldier and the State in a New Era, 265-289. edited by Suzanne C. Nielsen and Don M. Snider. Baltimore: The Johns Hopkins University Press, 2009.

- - . "Military Endorsements Harm National Interest." The Washington Times, October 15, 2000, sec. Letters to the Editor. http://www.washingtontimes.com/news/2000/oct/15/20001015-0121373090r/?page=all.

- - - "Out of Control: The Crisis in Civil-Military Relations | The National Interest." The National Interest, March 1, 1994. http://nationalinterest.org/article/out-of-control-thecrisis-in-civil-military-relations-343? page $=4$.

Lane, Robert Edwards. Political Ideology: Why the American Common Man Believes What He Does. New York: Free Press of Glencoe, 1962.

Lederman, Gordon Nathaniel. Reorganizing the Joint Chiefs of Staff : the Goldwater-Nichols Act of 1986. Westport, Conn.: Greenwood Press, 1999.

Lewis, David E. The Politics of Presidential Appointments: Political Control and Bureaucratic Performance. Princeton, N.J.: Princeton University Press, 2008.

Locher, James R. Victory on the Potomac : the Goldwater-Nichols Act Unifies the Pentagon. College Station: Texas A \& M University Press, 2002.

Londono, Ernesto. "Accusations Against Generals Cast a Long Shadow over Army." The Washington Post. October 28, 2012, sec. A.

Mann, Jim. Rise of the Vulcans : The History of Bush's War Cabinet. New York: Viking, 2004.

- - - The Obamians: The Struggle Inside the White House to Redefine American Power. New York: Viking, 2012.

Marsh, Kevin. "The Administrator as Outsider: James Jones as National Security Advisor." Presidential Studies Quarterly 42, no. 4 (December) (2012): 827-843.

Meilinger, Phillip S. "Soldiers and Politics: Exposing Some Myths." Parameters (Summer 2010): 74-86.

Miles, Donna. "Defense.gov News Article: Gates Praises Hayden as General Retires to Become Civilian CIA Director." American Forces Press Service, June 20, 2008. http://www.defense.gov/News/NewsArticle.aspx?ID=50268.

Moe, Terry M. "The Politicized Presidency." In The New Direction in American Politics, 269-271. edited by John E. Chubb and Paul E. Peterson. Washington, D.C.: Brookings Institution, c1985.

Moskos, Charles C. "Institutional/Occupational Trends in Armed Forces: An Update." Armed Forces \& Society (April 1986): 377-382. doi:10.1177/0095327X8601200303.

Moten, Matthew. "A Broken Dialogue: Rumsfeld, Shinseki, and Civil-Military Tension." In American Civil-Military Relations: The Soldier and the State in a New Era, 42-71. edited by Suzanne C. Nielsen and Don M. Snider. Baltimore: The Johns Hopkins University Press, 2009. 
Myers, Richard B., Richard H. Kohn, Mackubin Thomas Owens, Lawrence J. Korb, and Michael C. Desch. "Salute and Disobey?" Foreign Affairs, September 1, 2007.

http://www.foreignaffairs.com/articles/62843/richard-b-myers-and-richard-h-kohnmackubin-thomas-owens-lawrenc/salute-and-disobey.

Myers, Steven Lee. "Generally Speaking." The New York Times, April 6, 2008, sec. Week in Review. http://www.nytimes.com/2008/04/06/weekinreview/06myers.html.

National Academy of Public Administration. Independent Assessment of the Department of Defense Review of Post-Employment Restrictions, February 2012. http://www.napawash.org/wp-content/uploads/2012/05/FINAL-Academy-PanelReport-DoD-Post-Employment-Review-Assessment.pdf.

National Public Telecomputing Network. "21 Military Leaders Endorse Bill Clinton for President; Endorse a Strong Defense and A Strong Economy," October 12, 1992. http://stuff.mit.edu:8001/afs/net/user/tytso/usenet/nptn/campaign92/dems/76.

Neustadt, Richard E. Presidential Power and the Modern Presidents : The Politics of Leadership from Roosevelt to Reagan. New York: Free Press, 1990.

O'Sullivan, Christopher D. Colin Powell : American Power and Intervention from Vietnam to Iraq. Lanham, Md.: Rowman and Littlefield, c2009.

Oberdorfer, Don. Senator Mansfield: The Extraordinary Life of a Great American Statesman and Diplomat. Washington DC: Smithsonian Books, 2003.

"Office of Air and Marine - CBP.gov." Accessed December 4, 2012. http://www.cbp.gov/xp/cgov/about/organization/assist_comm_off/amo_assistant_com missioner.xml.

Owens, Mackubin Thomas. US Civil-Military Relations After 9/11 : Renegotiating the CivilMilitary Bargain. New York: Continuum, 2011.

Partnership for Public Service. Mission-Driven Mobility: Strengthening Our Government Through a Mobile Leadership Corps, February 29, 2012.

http://ourpublicservice.org/OPS/publications/viewcontentdetails.php?id=172.

Powell, Colin L., and Joseph E. Persico. My American Journey: An Autobiography. Random House, 1995.

Raddatz, Martha, Richard Coolidge, Sherisse Pham, and Jordyn Phelps. "Interview with Former Marine Corps General: Women in Combat Long Overdue | Power Players - Yahoo! News," January 30, 2013. http://news.yahoo.com/blogs/power-players-abcnews/former-marine-corps-general-women-combat-long-overdue-123830231.html.

Reardon, Carl. "View From the Ranks: The Social and Cultural History of the American Armed Forces." OAH: Magazine of History (October 2008): 11-16.

Ricks, Thomas E. "Rumsfeld on High Wire of Defense Reform: Military Brass, Conservative Lawmakers Are Among Secretive Review's Unexpected Critics." Washington Post, May 20, 2001.

-- - The Generals: American Military Command from World War II to Today. New York: The Penguin Press, 2012.

- - . "The Widening Gap Between Military and Society." The Atlantic, July 1997. http://www.theatlantic.com/magazine/archive/1997/07/the-widening-gap-betweenmilitary-and-society/6158/.

Robbert, Al. "Developing Leadership: Emulating the Military Model." In High-Performance Government: Leadership, Structure, Incentives, 255-281. edited by R. Klitgaard and P.C. Light. Santa Monica, CA: RAND Corporation, 2005. http://www.rand.org/content/dam/rand/pubs/monographs/2005/RAND_MG256.pdf. 
Roe, Mike. "California Sen. Feinstein Says She Wishes Obama Had Not Accepted Petraeus Resignation." KPCC, November 9, 2012.

http://www.scpr.org/blogs/news/2012/11/09/11015/california-sen-feinstein-says-shewishes-obama-had/.

Roman, Peter J., and David Tarr. "The Joint Chiefs of Staff: From Service Parochialism to Jointness." Political Science Quarterly 113, no. 1 (1998): 91-111.

Roman, Peter J., and David W. Tarr. "Military Professionalism and Policymaking: Is There a CivilMilitary Gap at the Top? If So, Does It Matter?" In Soldiers and Civilians: The CivilMilitary Gap and American National Security, 403-428. Cambridge, Mass: MIT Press, 2001.

Rossiter, Clinton. Conservatism in America. 2d ed., rev. New York,: Knopf,, 1971.

Schiff, Rebecca L. The Military and Domestic Politics: A Concordance Theory of Civil-Military Relations. London: Routledge, 2008.

Schmitt, Eric. "General to Be Disciplined For Disparaging President - New York Times." The New York Times, June 16, 1993. http://www.nytimes.com/1993/06/16/us/general-to-bedisciplined-for-disparaging-president.html.

- - - "Pentagon Contradicts General on Iraq Occupation Force's Size." The New York Times. February 28, 2003, Online edition. http://www.nytimes.com/2003/02/28/us/threatsresponses-military-spending-pentagon-contradicts-general-iraqoccupation.html?pagewanted=2\&src=pm.

Scowcroft, Brent. Miller Center Presidential Oral History Project, November 12, 1999. http://millercenter.org/president/bush/oralhistory/brent-scowcroft.

Senate Committee on Foreign Relations. Nomination of Alexander M. Haig, Jr., 1981.

Senate Committee on Homeland Security and Governmental Affairs, 110th Congress, $2 \mathrm{~d}$ Session. "Policy and Supporting Positions." U.S. Government Printing Office, Washington, D.C., November 12, 2008.

Senate Subcommittee on Personnel, Committee on Armed Services. Hearing to Receive Testimony on General and Flag Officer Requirements, 112th Cong., 1st Sess. Washington DC, September 14, 2011.

Shane, Scott. "C.I.A. to Expand Use of Drones in Pakistan." The New York Times, December 4, 2009, sec. International / Asia Pacific. http://www.nytimes.com/2009/12/04/world/asia/04drones.html.

Shanker, Thom. "Gen. Wayne A. Downing, 67, Special Operations Leader, Dies - New York Times." The New York Times, July 19, 2007. http://www.nytimes.com/2007/07/19/washington/19downing.html?_r=0.

Siebold, Guy L. "Core Issues and Theory in Military Sociology." Journal of Political and Military Sociology (Summer 2001): 140-159.

Skocpol, Theda. "Bringing the State Back In: Strategies of Analysis in Current Research." In Bringing the State Back In, 3-43. edited by Peter B. Evans, Dietrich Rueschemeyer, and Theda Skocpol. Cambridge, Mass: Cambridge University Press, 1985.

Smith, Jean Edward. Eisenhower in War and Peace. New York: Random House, 2012.

Smith, Rogers M. "Beyond Tocqueville, Myrdal, and Hartz: The Multiple Traditions in America." American Political Science Review 87, no. 3 (September 1993): 549-567.

Somit, Albert. "The Military Hero as Presidential Candidate." The Public Opinion Quarterly 12 (July 1, 1948): 192-200.

Stouffer, Samuel A., Edward A. Suchman, Leland C. DeVinney, Shirley A. Star, and Robin M. Williams. The American Soldier: Adjustment During Army Life. Princeton, N.J.: Princeton University Press, 1949. 
Sullivan, Eileen. "Robert Harding, Obama's Second TSA Nominee, Withdraws From Consideration." Huffington Post, March 27, 2010.

http://www.huffingtonpost.com/2010/03/27/robert-harding-obamassec_n_515690.html.

Teigen, Jeremy M. "Veterans' Party Identification, Candidate Affect, and Vote Choice in the 2004 US Presidential Election." Armed Forces \& Society 33, no. 3 (April 2007): 414-437.

Timberg, Robert. The Nightingale's Song. New York: Simon \& Schuster, 1995.

Timm, Jane C. "Colin Powell: The Second Amendment Calls for Regulations, You Know MSNBC." NBCNEWS.com, January 21, 2013. http://tv.msnbc.com/2013/01/21/colinpowell-the-second-amendment-calls-for-regulations-you-know/.

Tocqueville, Alexis de. Democracy in America. Translated by Harvey C. Mansfield and Delba Winthrop. Chicago: University of Chicago Press, 2011.

Trainor, Bernard E. "Man in the News: James David Watkins; A Compassionate Pragmatist." The New York Times, June 4, 1988, sec. U.S. http://www.nytimes.com/1988/06/04/us/manin-the-news-james-david-watkins-a-compassionate-pragmatist.html.

U.S Office of Personnel Management. History of SES. Accessed September 26, 2012. http://www.opm.gov/ses/about_ses/history.asp.

Ulrich, Marybeth P. "The General Stanley McChrystal Affair: A Case Study in Civil-Military Relations." Parameters (Spring 2011): 86-100.

United States Department of State, Office of Inspector General. Inspection of Embassy Nairobi, Kenya, August 2012. http://oig.state.gov/documents/organization/196460.pdf.

United States. Congress. "National Defense Authorization Act for Fiscal Year 2000 : Conference Report to Accompany S. 1059.," 1999. http://search.lib.virginia.edu/catalog/011333023.

United States. Congress. "Civil Service Reform Act of 1978 : Conference Report to Accompany S. 2640.," 1978. http://search.lib.virginia.edu/catalog/u5073864.

United States. Constitutional Convention. The Records of the Federal Convention of 1787,. Vol. 1. 3 vols. New Haven,: Yale University Press,, 1911.

University of Michigan. Survey Research Center. The American Voter. New York, Wiley, 1960.

Vanden Brook, Tom, Ken Dilanian, and Ray Locker. "Retired Military Officers Cash in as Well-Paid Consultants." USA Today, November 18, 2009.

Volcker Commission. Urgent Business for America: Revitalizing the Federal Government for the 21st Century. National Commission on the Public Service, January 4, 2003. http://ourpublicservice.org/OPS/publications/viewcontentdetails. php?id=92.

Watkins, Shanea, and James Sherk. Who Serves in the U.S. Military? The Demographics of Enlisted Troops and Officers. Washington D.C.: Heritage Foundation: Center for Data Analysis, August 21, 2008. http://www.heritage.org/research/reports/2008/08/whoserves-in-the-us-military-the-demographics-of-enlisted-troops-and-officers.

Weigley, Russell F. "The American Civil-Military Cultural Gap: A Historical Perspective, Colonial Times to the Present." In Soldiers and Civilians: The Civil-Military Gap and American National Security, 215-246. edited by Peter D. Feaver and Richard H. Kohn. Cambridge, Mass: MIT Press, 2001.

White House: Office of the Press Secretary. "President Announces Appointment of Fred F. Woerner and F. Haydn Williams as Members of the American Battle Monuments Commission." May 27, 1994. http://clinton6.nara.gov/1994/05/1994-05-27-presidentnames-members-to-american-battle-commission.html.

Woodward, Bob. Obama's Wars. New York: Simon \& Schuster, 2010.

- - . Plan of Attack. New York, NY: Simon \& Schuster, 2004.

- - - The Commanders. New York: Simon \& Schuster,, 1991. 
- - . The War Within. New York: Simon \& Schuster, 2008.

Wrona, Richard M. Jr. "A Dangerous Separation: The Schism Between the American Society and Its Military." World Affairs 169, no. 1 (2006): 25-38.

Yaeger, John W., and L. Erik Kjonnerod. "Educating National Security Professionals for Stabilization and Reconstruction." In Civilian Surge: Key to Complex Operations, 195212. edited by Hans Binnendijk and Patrick M. Cronin. Washington D.C.: National Defense University Press, 2009.

Yardley, William. "Adm. James D. Watkins, 85, AIDS Panel Leader, Dies - NYTimes.com." The New York Times, July 31, 2012. http://www.nytimes.com/2012/07/31/us/adm-james-dwatkins-85-aids-panel-leader-dies.html?_r=1\&.

Zegart, Amy B. "Petraeus a Poor Fit for CIA - Times Union." Timesunion.com, November 24, 2012. http://www.timesunion.com/opinion/article/Petraeus-a-poor-fit-for-CIA4064042.php.

Zuckerman, Alan S. "Returning to the Social Logic of Political Behavior." In The Social Logic Of Politics: Personal Networks As Contexts For Political Behavior, 3-20. edited by Alan S. Zuckerman. Philadelphia: Temple University Press, 2005. 